\author{
UNIVERSIDADE DE SÃO PAULO \\ ESCOLA DE ENGENHARIA DE SÃO CARLOS \\ DEPARTAMENTO DE ENGENHARIA MECÁNICA
}

\title{
Análise de Alguns Parâmetros Tecnológicos da Usinagem de Aç-Carbono por Eletroerosão
}

JOÃO TELÉSFORO NÓBREGA DE MEDEIROS

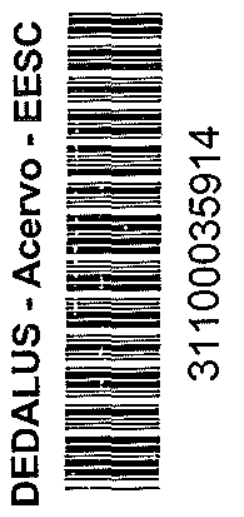

Orientador: João Lirani, PhD

Dissertação apresentada à Escola de Engenhariá de São Carlos, da Universidade de São Paulo, como parłe dos requisitos necessários à obtenção do Título de Mestre em Engenharia Mecânica. 


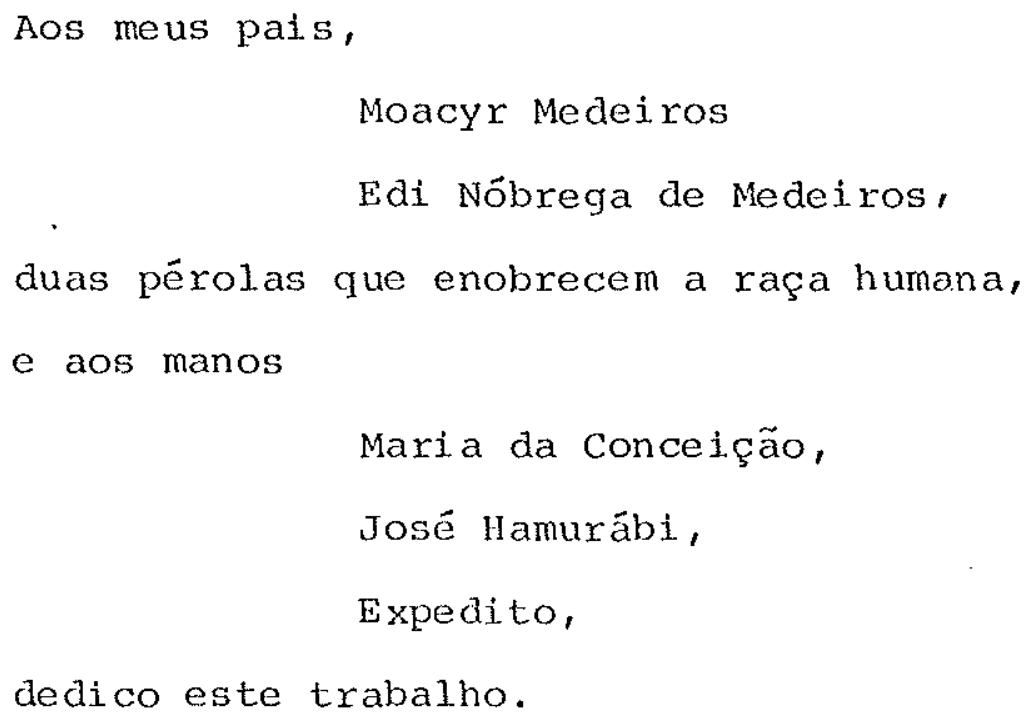


Expresso os meus agradecimentos:

- Ao Prof. Vinício Duarte Ferreira, da UFPb, pelo irrestri to apoio e incentivo prestados desde meus tempos de aluno da Escola Técriica Federal da Paraíba;

- Ao Prof. Dr. João Lirani, orientador deste trabalho, pelas valiosas sugestöes e colaboração transmitidas durante a sua realização;

- Ao prof. Dr. Rosalvo Tiago Ruffino e ao Prof. José Rober to Gambarini, pelo incentivo e colaboração prestados;

- Aos colegas Eduardo Vila Gonçalves Filho, João Carlos Reis Rabelo, Alceu Rodrigues da Cruz Júnior, Benedito Di. Giacomo e José Maria Campos dos Santos, pela colaboração prestada;

- Aos colegas da UFRN e UFPb que cursam programas de pósgraduação em são carlos e me ajudaram a minorar a saudade da terra e do povo nordestinos, e me toleraram pacien temente durante todo esse tempo;

- À bibliotecária Neuza T. Celere pelo eficiente trabalho desenvolvido;

- Aos técnicos de laboratório Helvécio Eugênio e Luiz Carlos Bruno, pelos serviços executados;

- Ao Sr. Antonio Gallo, pelo dedicado e primoroso trabalho de datilografia; 
- Aos funcionários da Secretaria do Departamento de Engenharia Mecânica da EESC-USP, pela colaboração prestada;

- A todos os meus professores, colegas e alunos, de ontem e de hoje, pelo estímulo e amizade sempre demonstrados;

- Aos amigos são-carlenses que me dispensaram uma atenção e desvelo imerecidos;

- A todos aqueles que, direta ou indiretamente, contribuíram para a realização deste trabalho. 

RJAIS POR PROCESSOS NÃO-CONVENCIONAIS

2.1 Generalidades $\ldots \ldots \ldots \ldots \ldots \ldots \ldots \ldots \ldots \ldots \ldots$

2.2 Natureza de um Processo de Fabricação ..... 5

2.3 Processos Não-Convencionais de Usinagem ... 10

CAPITULO 3 FUNDAMENTOS DA USINAGEM DE METAIS POR ELETROEROSÃO

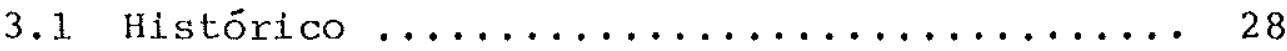

3.2 A Descarga Elétrica ............... 34

3.2.1 A Descarga Elétrica em Meio Gasoso . 34

3.2.2 A Descarga Elétrica em Líquido Dielé trico ................. 37

3.3 Aplicações Industriais do Processo de Usina gem por Descargas Elétricas ......... 42

3.3 .1 Usinagem por Eletroerosão ....... 46

3.3.2 Retificação por Eletroerosão ...... 48

3.3.3 Serramento por Eletroerosão ...... 49

3.3.4 Corte com Fio por Eletroerosão ..... 51

CAPITULO 4 MÁQUTNAS, FERRAMENTAS E ASPECTOS ECONOMTCOS DA USINAGEM DE METAIS POR ELETROEROSÃO 
Página

4.2 Măquinas UEe $\ldots \ldots \ldots \ldots \ldots \ldots \ldots \ldots \ldots \ldots \ldots$

4.2 .1 Conjunto Mecânico $\ldots \ldots \ldots \ldots \ldots \ldots, 57$

4.2 .2 Conjunto Elétrico ............ 58

4.2.3 Conjunto Hidráulico ............. 62

4.3 Ferramentas UEE .................. 63

4.3.1 Cobre Eletrolítico ............ 64

4.3 .2 Grafite ..................... 65

4.3.3 Cobre ao Telúrio, ao Cromo ou ao Chumbo .................... 66

4.3 .4 Cobre-Tungstênio ............. 66

4.3 .5 Tungstênio à Prata $\ldots \ldots \ldots \ldots \ldots \ldots 66$

4.3.6 Liga de Alumínio (Silumin) ...... 67

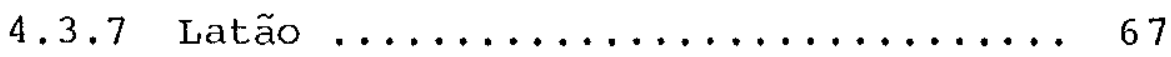

4.3 .8 Tungstênio. Molibdênio ......... 68

4.3 .9 Aço $\ldots \ldots \ldots \ldots \ldots \ldots \ldots \ldots \ldots \ldots \ldots .6 \% \ldots$

4.4 Aspectos Econômicos da Fabricação de u'a Ma triz para Forjamento por UEE e Fresamento por Copiamento ......................69 69

4.4 .1 Generalidades ................ 69

4.4 .2 Descrição da Matriz Usinada ....... 70

4.4.3 Anälise dos Tempos de Fabricação da Matriz .................. 70

4.4.4 Análise dos Custos de Fabricação da Matriz .................. 72

CAPÍTULO 5 PARÂMETROS TECNOLOGICOS DO PROCESSO

5.1 Generalidades $\ldots \ldots \ldots \ldots \ldots \ldots \ldots \ldots \ldots .77$

5.2 Parâmetros Elétricos $\ldots \ldots \ldots \ldots \ldots \ldots \ldots \ldots$

5.2.1 Energia de Descarga ............ 78

5.2 .2 Corrente de Descarga ........... 80

5.2 .3 Frequência de Descargas ......... 82

5.2.4 Resistividades dos Elétrodos ...... 83 
pāgina

5.2 .5 Polaridade do Circuito ......... 84

5.2.6 Propriedades Dielétricas do Fluido de serviço ................. 85

5.3 Parâmetros Termodinâmicos ........... 86

5.4 Parâmetros Hi drodinâmi cos ........... 88

5.5 Parâmetros Metalúrgicos ............ 92

5.6 Parâmetros Mecânicos ............... 93

5.7 Parâmetros Geométricos .............. 94

CAP ITULO 6 ANÁLISE EXPERIMENTAL DA USINAGEM DE AÇOCARBONO POR ELETROEROSÃO. RESULTADOS OBTIDOS

$6.1 \quad$ Generalidades ................... 95

6.2 Descrição do Equipamento Eletroerosivo uti-

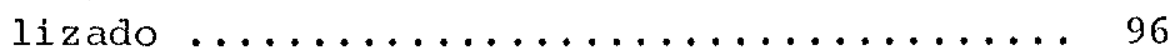

6.3 Projeto e Fabricação dos Elëtrodos de en-

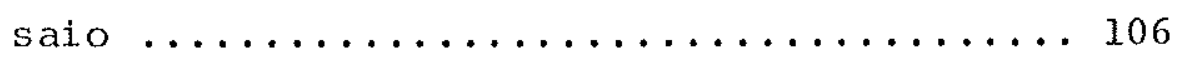

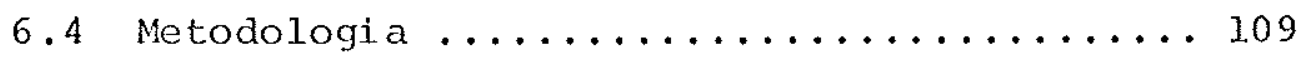

6.5 Resultados e Discussões ............ 116

CAPITULO 7 CONCLUSÕES. SUGESTÕES PARA TRABALHOS FUTUROS

7.1 Conclusões ................... 145

7.2 Sugestões para Prabalhos Futuros ....... 146

CAPITULO 8 BIBLIOGRAFIA

8.1 Referências Bibliogräficas .......... 148

8.2 Bibliografia Consultada ........... 151 


\section{APENDICE}

APENDICE A Glossário de Termos Utilizados no

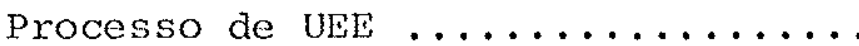

APENDICE B Dimensionamento de Elétrodos-Ferramenta e Estimativa do Tempo de Usinagem por Eletroerosão ......... XV 


\section{SIMBOLOGIA E UNIDADES}

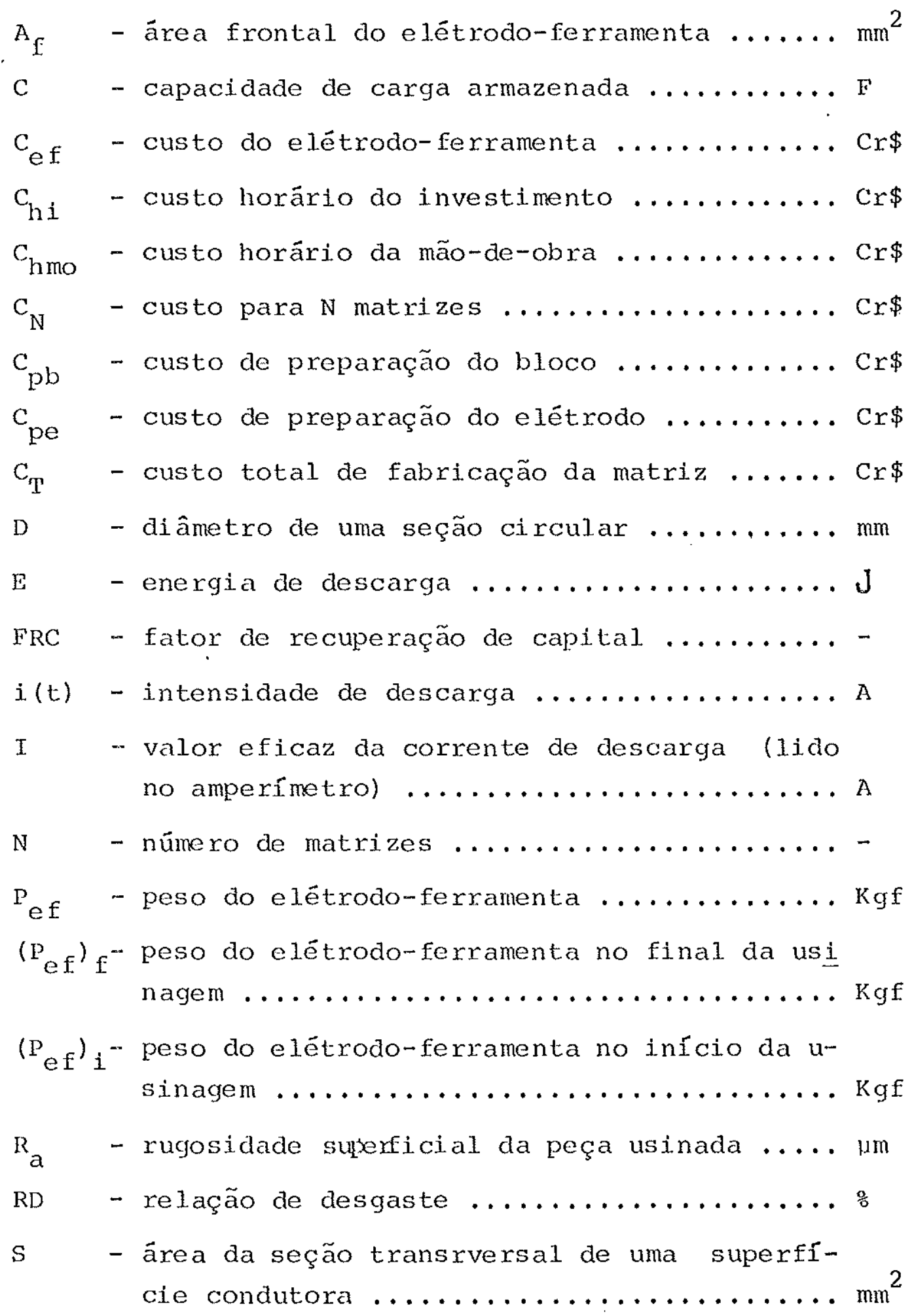


$\mathrm{S}_{\mathrm{L}} \quad-$ sobrecorte lateral $\ldots \ldots \ldots \ldots \ldots \ldots \ldots \ldots$

$\mathrm{T}_{t} \quad-$ tempo total de usinagem $\ldots \ldots \ldots \ldots \ldots \ldots \ldots$

. $\quad$ - tempo de descarga $\ldots \ldots \ldots \ldots \ldots \ldots \ldots \ldots \ldots$

V - valor eficaz da tensão de descarga (1ido no voltímetrol $\ldots \ldots \ldots \ldots \ldots \ldots \ldots \ldots$

VRM - velocidade de remoção de material ...... $\mathrm{mm}^{3} / \mathrm{min}$

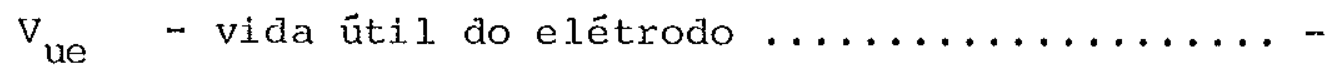

$v(t) \quad-$ tensão instantânea de descarga ......... v

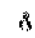

$\gamma_{\text {ef }}$ - peso especifico do material do elétrodo-fer ramenta $\ldots \ldots \ldots \ldots \ldots \ldots \ldots \ldots \ldots \ldots \ldots \ldots \ldots \ldots \ldots \mathrm{Km}^{3}$

$\gamma_{\mathrm{p}} \quad-$ peso específico do material da peça usinada $\mathrm{Kgf} / \mathrm{dm}^{3}$

$\delta \quad-$ densidade de corrente $\ldots \ldots \ldots \ldots \ldots \ldots / \mathrm{m}^{2}$

- conicidade de cada lado da peça usinada ... graus 
RES U MO

Analisaram-se os parâmetros tecnológicos mais sigg nificativos que influem na Usinagem por Eletroerosão(UEE). Foram desenvolvidos e comentados ensaios de usinagem de aço-carbono com elétrodos de cobre. Apresenta-se também um método de dimensionamento da ferramenta e da avaliação do tempo de usinagem, baseado nos dados obtidos. Foram confrontados os principais processos não-convencionais de usi nagem, constatando-se que a UEE é um eficiente processo de fabricação. 
The most important EDM technological parameters have been analyzed. Experiments on carbon-steel workpiece machined with copper tool-electrode have been developed and discussed. Based on the obtained data, this work suggests a method for designing the tool-electrode and evaluating the total machining time. Others usual non-traditional machining processes have been compared and it has been observed that EDM is an efficient manufacturing process. 
Saber estudar, possuir a arte de aprender, habilitar-se a navegar segu - ro por essas äguas e atraves desses escolhos, $j \vec{a} \vec{e}$ ser abastado nas posses, e ter aproveitado o tempo.

Ruy Barbosa 
1. INTRODUÇÃO

A segunda metade deste século tem apresentado $\underline{u}$ ma notável evolução na engenharia de projetos, na metalur gia e na engenharia de fabricação. Aquele tradicional des compasso de outros tempos entre a ciência e a tecnologia tem dado lugar, em nossos dias, a um desenvolvimento harmônico e acelerado da maioria dos setores da atividade hu mana.

Isso é fruto da contínua sofisticação e melhoria de projetos específicos, de vanguarda, em que a busca da otimização da relação resistência/peso, custos, propriedades físicas e químicas e funcionalidade do produto exige mais e mais da ciência dos materiais e dos processos de fabricação para atender de modo mais racional. às metas criticas da engenharia.

Exemplos palpáveis são encontrados nos campos da energia nuclear, onde a tecnologia dos reatores exige considerações dos efeitos da radiação sobre os materiais, e dos programas aerospaciais, através da construção de 
mísseis, aviões de alto desempenho e foguetes, que devem enfrentar condições ambientais completamente distintas e, às vezes, desconhecidas.

Os materiais produzidos em resposta a solicitações desse gênero tendem a ser mais quebradiços que dúcteis. Este fato, aliado a outros de igual importância, tais como tolerâncias reduzidas, formas intrincadas, superfícies adelgaçadas, microcavidades etc., têm induzido a com plementação dos métodos mecânicos de fabricação por outros que empregar a energia química, ou térmica, ou elétrica, ou combinações destas, envolvendo uma quantidade mínima de deformação mecânica: são os chamados "processos não-convencionais de usinagem", ou ainda "processos de usinagem sem cavaco ", gerados nos laboratórios de pesquisa após a Segunda Guerra Mundial e alguns já industrialmente consagrados em todo o mundo.

Para possibilitar uma melhor visualização dos processos não-convencionais de usinagem, avaliaram-se, no capítulo 2 , as suas potencialidades e limitações, tanto técnica, quanto economicamente, onde se constata que a usinagem por eletroerosão (UEE) é um eficiente processo em diversas aplicações.

Os capitulos 3, 4 e 5 apresentam os fundamentos tecnológicos da usinagem de metais por eletroerosão, as máquinas e as ferramentas empregadas nesse processo e se comparam aspectos econômicos da fabricação de uma matriz de forjamento pelos processos de fresamento por copiamento e usinagem por eletroerosão. Enfatizam-se, também, os parâmetros tecnológicos que influem na UEE.

Além dos aspectos teóricos da UEE, foram obtidos e avaliados dados experimentais em laboratório. Anali saram-se alguns parâmetros tecnológicos significativos da usinagem de um aço-carbono com elétrodo-ferramenta de cobre: velocidade de remoção de material, desgaste do elétrodo, conicidade, acabamento superficial e influência de 
determinadas condições da lavagem sobre o desempenho do processo eletroerosivo (capítulo 6).

Discutem-se, no capítulo 7, os dados obtidos e evidenciam-se a baixa capacidade de remoção de material. do circuito de relaxação, o alto desgaste do elétrodo-fex ramenta de cobre em operações de desbaste, e o surgimento de forças transmitidas por contato direto entre a ferramenta e a peça, devido às falhas de operação e às limitações inerentes ao servo-sistema eletro-hidräulico de comando do avanço do cabeçote porta-elétrodo.

Ainda no capitulo 7, enumeram-se algumas suges tões para trabalhos futuros e, no apêndice, apresenta-se um glossärio de termos técnicos utilizados no processo eletroerosivo e é proposto um método de dimensionamento de elétrodos para esse processo.

A abordagem do processo de usinagem por eletroerosão encetada neste trabalho visa a:

a) Ressaltar as potencialidades e limitações desse proces so;

b) Analisar os principais parâmetros que influem na UEE;

c) Descrever alguns mecanismos associados à remoção de ma terial por centelhas elétricas;

d) Avaliar, para uma combinação de elétrodos cobre/açocarbono, o desempenho do processo, em termos da veloci dade de remoção de material, desgaste da ferramenta, conicidade e acabamento superficial da cavidade executada, temperatura do banho dielétrico e influência das condições de lavagem;

e) Apresentar um método de dimensionamento do elétrodo-ferramenta utilizado no processo, ou conjunto de elétodos, que permita ao usuário estimar o tempo de opera ६ão, a qualidade final da superfície usinada e as dimensões prováveis do produto acabado. 
2. CONCEITOS BASICOS DA USINAGEM DE MATERIAIS POR PROCESSOS NÃO-CONVENCIONAIS

\subsection{Generalidades}

A interface fabricação/projeto de um produto re presenta um dos pontos mais críticos da engenharia, seja mecânica, eletrônica, naval ou aeronáutica. Custos do pro cesso, materiais utilizados, tolerâncias dimensionais, de forma e de posição, dificuldades de fabricação surgidas em decorrência da funcionalidade ou estética do produto etc., caracterizam aquela interface.

Apesar de inúmeras inovações tecnológicas surgi das nos últimos anos, com a introdução de computadores eletrônicos para assistix ao projeto ou à fabricação, a ab soluta maioria dos equipamentos em operação industrial, ainda incorpora unidades tradicionais, em que a perícia do operador é tão ou mais importante que as potencialidades da própria mäquina-ferramenta.

os custos de formação e manutenção de mão-de-o- 
bra de escol crescem a cada dia; a conjuntura sócio-econô mica de uma unidade fabril é diuturnamente afetada pelos condicionantes politicos que se lhe apresentam, além dos aspectos técnicos inerentes às suas atividades rotineiras.

O surgimento dos processos não-convencionais de usinagem decorreu da combinação entre aqueles fatos e a necessidade de se usinarem materiais de baixa usinabilida de pelos métodos convencionais, além da sofisticação e im posições de projetos cada vez mais ousados.

Posiciona-se, neste capitulo, a ULE no universo dos processos de fabricação, comparando-a com os demais processos não-convencionais de usinagem e com o fresamento convencional.

\subsection{Natureza de um Processo de Fabricação}

A seleção da melhor máquina ou processo para um determinado produto exige sólidos conhecimentos de todos os métodos de produção existentes. O fluxograma apresenta do na figura 1 sintetiza as diversas etapas que podem delinear a fabricação de uma peça. Assim como em uma malha PERT/CPM, geralmente há um caminho crítico mais econômico e satisfatório, dentre os possíveis. Fatores a serem considerados são o volume da produção, a qualidade do produto acabado, as vantagens e limitações dos vários tipos de equipamentos capazes de executar a tarefa e os custos de fabricação.

Em um processo de fabricação, o material passa por vários estados, caracterizados pelos seus parâmetros geométricos e físj.cos bem definidos. Na maioria dos casos, um processo envolve mudanças quer nas dimensões geométricas, quer nas propriedades da peça e pode ser visualizado qualitativamente como uma trajetória, no espaço tri dimensional contido no sólido geométrico esboçado na figu ra 2 , desde um estado inicial $\underline{A}$ até algum estado final $\underline{E}$, 


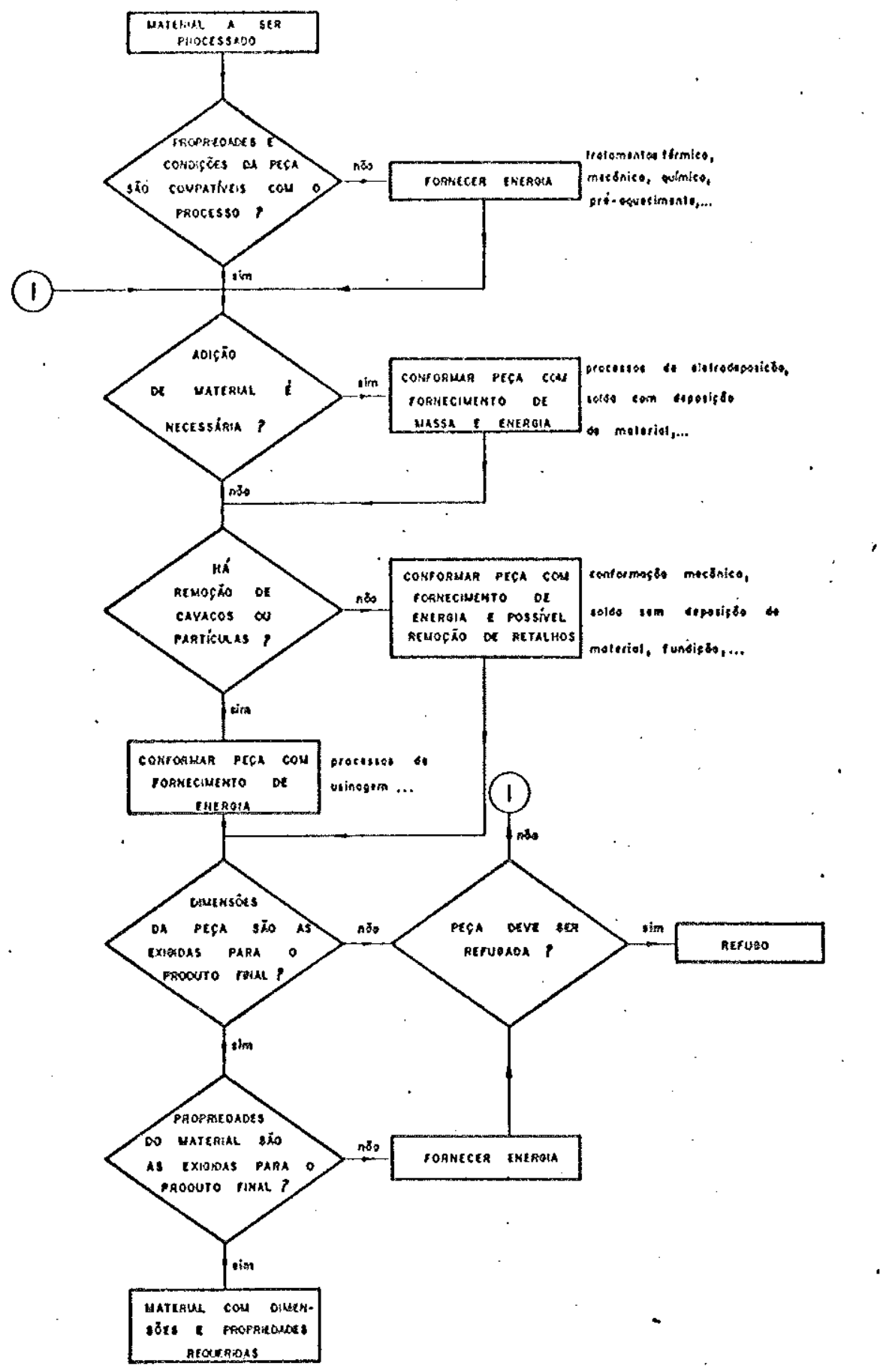

Fig. 1 - Principais etapas possíveis na fabri cação de uma peça na indústria mecẫ nica. 
em um determinado intervalo de tempo e por um custo definido, através de uma sucessão de estados. A qualquer instante de tempo, o estado do sistema é representado por um ponto cujas coordenadas são as dimensões da peça (d) , as propriedades do material ( $\underline{\text { p }}$ e o tempo de operação ( $\left.t_{0}\right)$.

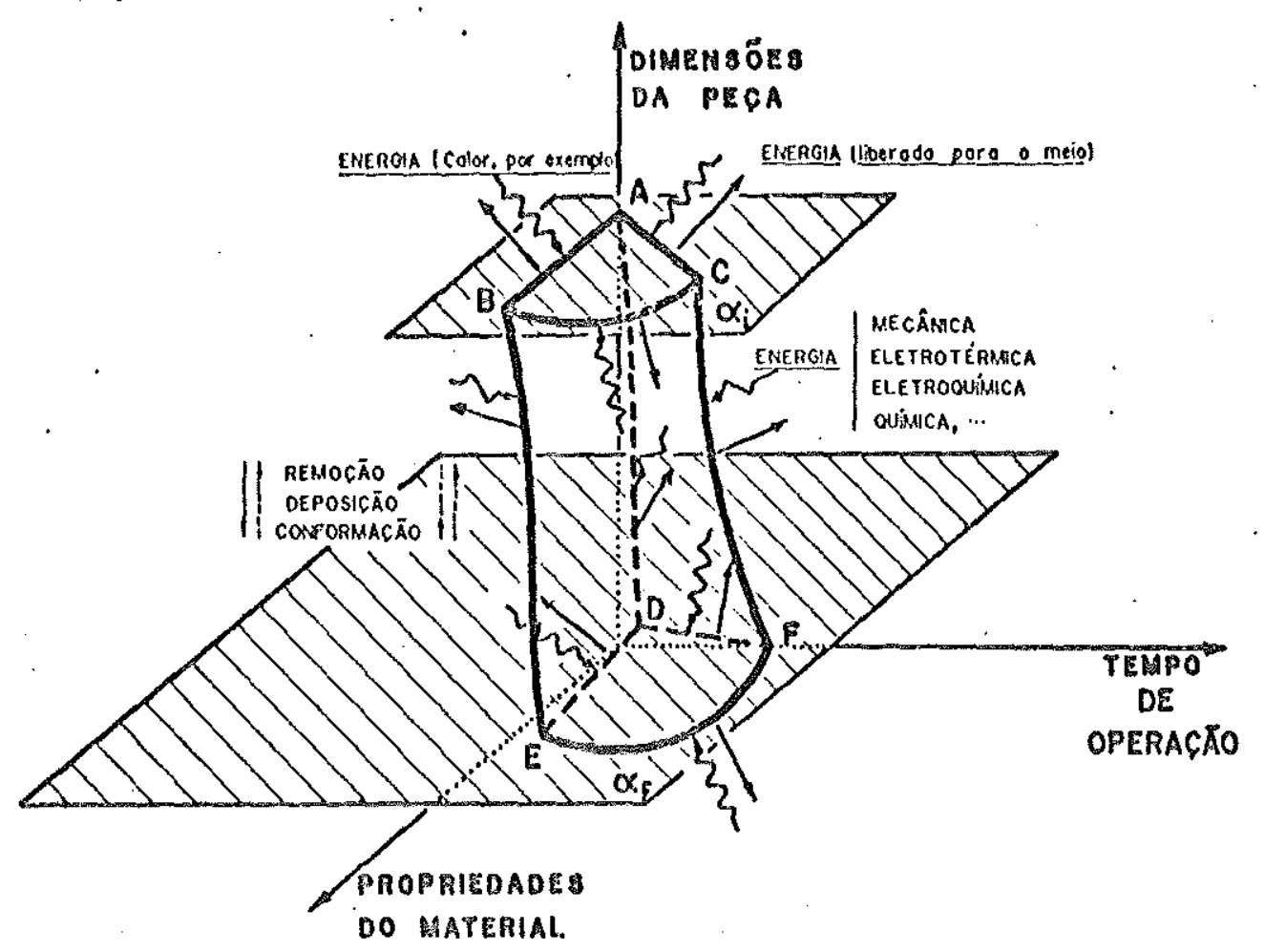

Fig. 2 - Conceituação grafo-abstrata de um processo de fabricação.

Sistema, neste caso, é uma porção da matéria de identidade bem determinada, capaz de interagir com o meio - ambiente em termos de fluxo de massa e energia.

Ora, na apreciação do desempenho dos processos de fabricação, diversos parâmetros devem ser definidos, dependendo da natureza do processo, do sistema considerado e dos fatores políticos, sociais e econômicos envolvidos. Isto, afinal de contas, está intrinsecamente ligado 
às premissas fundamentais da tecnologia, pois todo um cam po de reações e relações humanas está envolvido nas suas atividades. Há 116 anos, o regulamento de fundação do Massachusetts Institute of Technology (MIT), já salientava ponto-de-vista análogo:

..."intended fon those who seek administrative positions in business where a systematic study of political and social relations and bamiliarity with scientific methods an processes are equally essential".

(...destinado àqueles que buscam posições administrativas nos negócios em que um estudo siste mático das relações políticas e sociais e familiaridade com métodos e processos cientificos são igualmente importantes).

Entretanto, em uma abordagem mais compacta, um processo de fabricação pode ser sintetizado pelo esquema da figura 2, envolvendo um sistema com propriedades e dimensões bem definidas, no tempo. Quando esse sistema se move de algum estado inicial para algum estado final, em uma sucessão de estados, há necessariamente uma troca de energia, associada aos microconstituintes do material, en tre o sistema e o seu meio-ambiente. O rearranjo desses e lementos microscópicos se dá quando variam algumas propriedades e/ou a configuração geométrica do material. Esta, por sua vez, altera-se sempre que o processo envolva remoção, conformação ou deposição de material, ou seja, o sistema percorra um caminho em que haja mudança de estado no eixo dos d (dimensões da peça). Diferentes caminhos en tre dois estados constituem processos distintos; o estado final necessariamente se situa à direita do inicial, no sentido positivo do eixo dos tempos de operação, dada a sua característica de irreversibilidade.

Uma operação de conformação mecânica, ou de usi nagem, ou de solda, ou de eletrodeposição, por exemplo,po 
de ser muito bem representada qualitativamente por um des ses caminhos e envolve uma mudança de plano: o estado ini cial pertence ao um plano $\alpha_{i}$ e o final a um plano $\alpha_{f}$. Um tratamento térmico, etapa integrante de vários processos de fabricação, pode ser delineado por caminhos situados em um mesmo plano $\alpha$, desde que ele não envolva mudanças significativas nas dimensões da peça, mas na sua estrutura interna.

Desde o século passado, quando as primeiras máquinas-ferramenta foram acionadas eletricamente, tem havi do uma evolução no sentido de se construirem máquinas mais rápidas, de se obterem velocidades cada vez maiores, avan ços mais rápidose acuracidadesaumentadas. Buscam-se mejos de trabalhar os materiais, sejam metálicos ou não, com um mínimo de processamento a partix do seu estado natural, com um mínimo de perdas e a maiores velocidades de produção. Procura-se, pois, minimizar o caminho $\overline{\mathrm{AF}}$, do gráfico da figura 2 .

O caminho $\overline{\mathrm{AB}}$, ou $\overline{\mathrm{BC}}$, ou $\overline{\mathrm{AC}}$, pode ser um tratamento tërmico, ou um pré-aquecimento dispensáve1, desde que se utilize um processo que elimine essa etapa, de for ma a não majorar os custos nem prejudicar os parâmetros geométricos e físicos do estado final, F. Analogamente, $\overrightarrow{\mathrm{DE}}$, ou $\overrightarrow{\mathrm{EF}}$, ou $\widetilde{\mathrm{DE}}$, pode representar um tratamento térmico, ou um jateamento, igualmente dispensável, na condição ací ma.

A trajetória $\overline{\mathrm{AE}}$, ou $\overline{\mathrm{AD}}$, ou $\overline{\mathrm{BE}}$, ou $\overline{\mathrm{BD}}$, pode ser um fresamento ou uma extrusão, ou um torneamento, ou uma usinagem por eletroerosão, por exemplo; por outro lado, $\widehat{\mathrm{EC}}$, ou $\widehat{\mathrm{DC}}$, pode representar uma sinterização, ou uma eletrockeposição, ou um recobrimento inorgânico etc.

De acordo com o número de peças a ser produzido, dispondo-se de todas as características dos estados $\underline{i}$ nicial e final do material a ser processado, pode-se produzir econômica e acuradamente pela delineação do caminho crítico entre esses dois estados. 
Para isso, é sumamente importante ao engenheiro saber discernix os processos nos quais várias formas de e nergia podem ser eficientemente fornecidas pelo meio-ambi ente ao material, de modo que produzam as propriedades e configuração geométrica final desejadas mediante as melho res condições obteníveis de custo e tempo de operação.

\subsection{Processos Não-Convencionais de Usinagem}

Ferraresi ${ }^{1}$ define operações de usinagem como sendo "aquelas que, ao conferir à peça a forma, ou as dimensões, ou o acabamento, ou ainda uma combinação qualquer destes três itens, produzem cavaco"; ... "cavaco é a porção de material da peça, retirada pela ferramenta, ca racterizando-se por apresentar forma geométrica irregu1ar". Entretanto, os processos não convencionais de usina gem são apropriadamente chamados "processos de usinagem sem cavaco" porque removem partículas (íons, moléculas, esférulas) do material da peça por fusão, vaporização e/ /ou reações químicas e dificilimente são visíveis a olho nu.

operações de usinagem, em um aspecto mais abran gente, poderiam ser definidas como sendo aquelas que, ao conferir à peça a forma, ou as dimensões, ou o acabamento, ou ainda uma combinação qualquer destes três itens, produ zem uma remoção de material sob a forma de cavacos ou par tículas, de acordo com o tipo primordial de energia utili zado no mecanismo dessa remoção.

Se a energia operante é a mecânica, necessariamente há um contato físico entre a ferramenta e a peça,en sejando a formação de cavaco, como nas operações de torneamento, fresagem, furação, aplainamento etc.; se a ener gia operante é do tipo eletrotérmica, por exemplo, não há contato físico entre a ferramenta e a peça, sendo o processo de remoção caracterizado pela formação de partículas, como na usinagem com laser, com feixe eletrônico,por eletroerosão etc. 
Para um determinado material, um processo de fa bricação pode ser sintetizado através das especificações dos elementos a seguir:

- tipos de energia envolvidos

- meios pelos quais a energia é fornecida ao ma terial, sob controle adequado

- fatores ambientais interagentes

- histoorico das mudanças, no tempo, pelas quais passa o material desde o estado inicial até o estado final

- anälise de custos.

Micheletti' e Springborn ${ }^{2}$ apresentaram uma clas sificação genéxica para os processos de fabricação que utilizam as tecnologias não-convencionais de usinagem na produção de peças. Essa classificação, muito simplificada, baseia-se na forma de energia predominante em cada processo e é apresentada nas Figuras 3, 4, e 5. Saliente-se que, nos processos produtivos, as formas de energia utilizadas constituem um conjunto denso combinado e não hä nenhum processo de remoção de material que utilize ape nas uma forma de energia, muito embora sempre haja um ti-po fundamental empregado, a sabex:

- energia mecânica (figura 3)

- energia eletrotérnica (figura 4)

- energia eletroquímica (figura 5.a)

- energia química (figura 5.b).

os processos não-convencionais de usinagem (PNCU) utilizam a energia de forma diferente daquela adotada nor malmente nas usinagens com remoção de cavaco (torneamento, furação, fresamento etc.) ou por deformação plästica (dobra, embutimento, recartilhagem etc.). A usinagem é fei ta por erosão, ou seja, com remoção de material sob forma de 
partículas, cujas dimensões variam em una larga faixa, pois essas partículas podem ser íons, colóides ou esférulas de algumas dezenas de micra.

Os processos de fabricação tradicionais exigem uma maior dureza da ferramenta em relação à da peça:o con tato físico direto entre ambas, a presença de cavacos ou deformação plástica do material, a geometria da zona de corte ativa, o modo de utilização da energia etc., são elementos que bem caracterizam tais processos.

Seja uma usinagem por torneamento, por exemplo.

O fornecimento de energi a mecânica à peça provocará nesta, via ferramenta de corte, uma remoção de material, alterando o seu estado inicial. o processo se caracteriza por uma geração de calor, transmitido parcialmente para - meio-ambiente, e pelo desenvolvimento de forças de corte que provocam vibração do sistema "estrutura da máquina - ferramenta de corte-peça". A combinação destes dois fato res também pode ensejar problemas de distorção e fixação da peça. O transporte e a reciclagem dos cavacos resultan tes da usinagem também envolvem considerável consumo de $\underline{e}$ nergia e tempo.

Nos processos não-convencionais de usinagem, ao contrário, não há necessidade de uma maior dureza da ferramenta em relação à peça, nem hă forças transmitidas por contato direto entre a ferramenta e a peça ${ }^{2}$. Isso será dis cutido posteriormente. Alëm disso, o desgaste da ferramen ta, nesses processos, seque leis completamente diversas daquelas que regem o dos métodos convencionais.

o efeito do fornecimento de uma determinada quantidade de energia a um material depende da fonte de energia e do mecanismo pelo qual o material interage com essa fonte. Isso pode ser depreendido pela análise do diagrama apresentado na figura 3, que enfeixa os processos de usinagem que utilizam predominantemente a energia mecânica. Dentre os processos que utilizam esse tipo de energia, destacam-se, como não-convencionais, aqueles em 


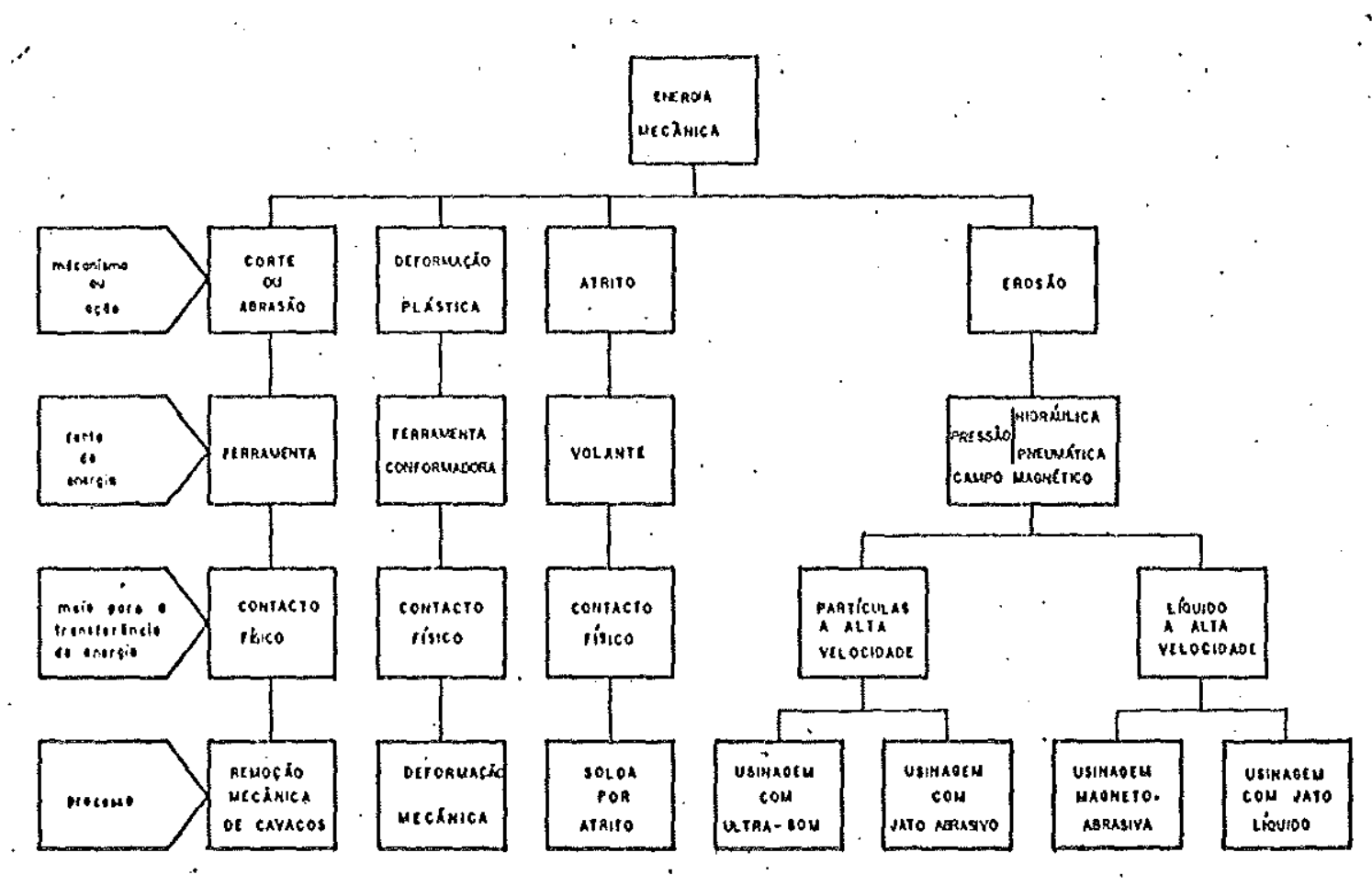

Fig. 3 - Processos não-convencionais de usinagem que empregam fundamentalmente a energia mecânica ${ }^{2}$

que a erosão é o mecanismo principal de remoção do material:

- usinagem com ultra-som, UUS (ultrasonic machining, USM)

- usinagem com jato abrasivo, UJA (abrasive jet machining, AJM)

- usinagem magneto-abrasiva, UMA (magneto-abrasive machining, MAM)

- usinagem com jato 1íquido, UJu (vater jet machining, WJM) •

A figura 4 apresenta os processos de usinagem cuja principal modalidade de energia operante é a eletrotérmica, que emprega a vaporização e/ou fusão para remover material da peça. Distinguem-se:

- usinagem por eletroerosão, UEE (electric-discharge machining, EDM) 

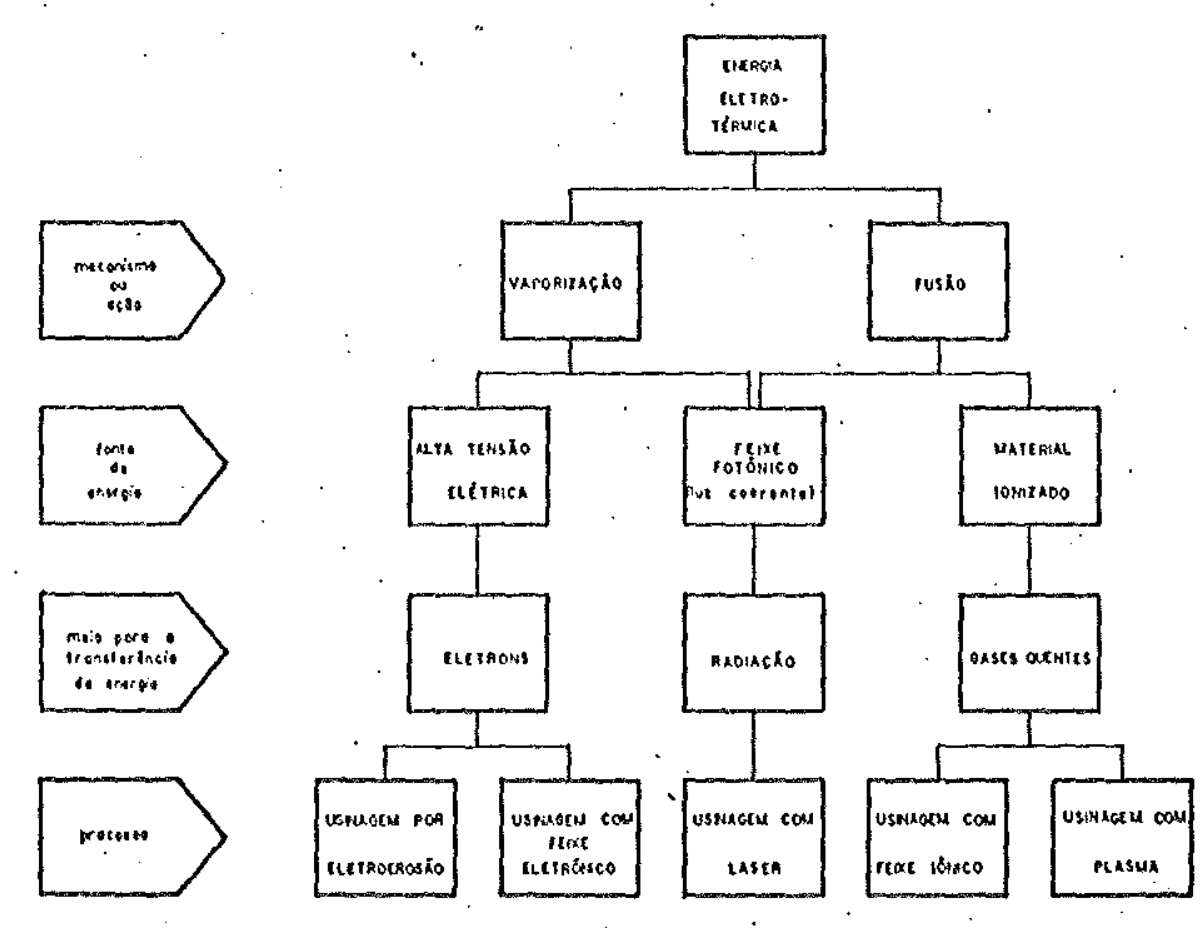

Fig. 4 - Processos não-convencionais de usinagem que empregam fundamentalmente a energia eletrotérmica ${ }^{2}$

- usinagem com feixe eletrônico, UFE (electron beam machining, EBM)

- usinagem com laser, ULA (laser beam machining, LBM)

- usinagem com feixe iônico, UFI (ion beam machining, IBM)

- usinagem com plasma, UPL (plasma arc machining, PAM).

Utilizando--se um procedimento inverso àquele do recobrimento eletrolítico, os processos que utilizam a energia eletroquímica são apresentados na figura 5.a.são eles:

- usinagem eletroquímica, UEQ (electro-chemical machining, ECM)

- retificação eletroquímica, REQ (electro-chemical. grinding, ECG). 


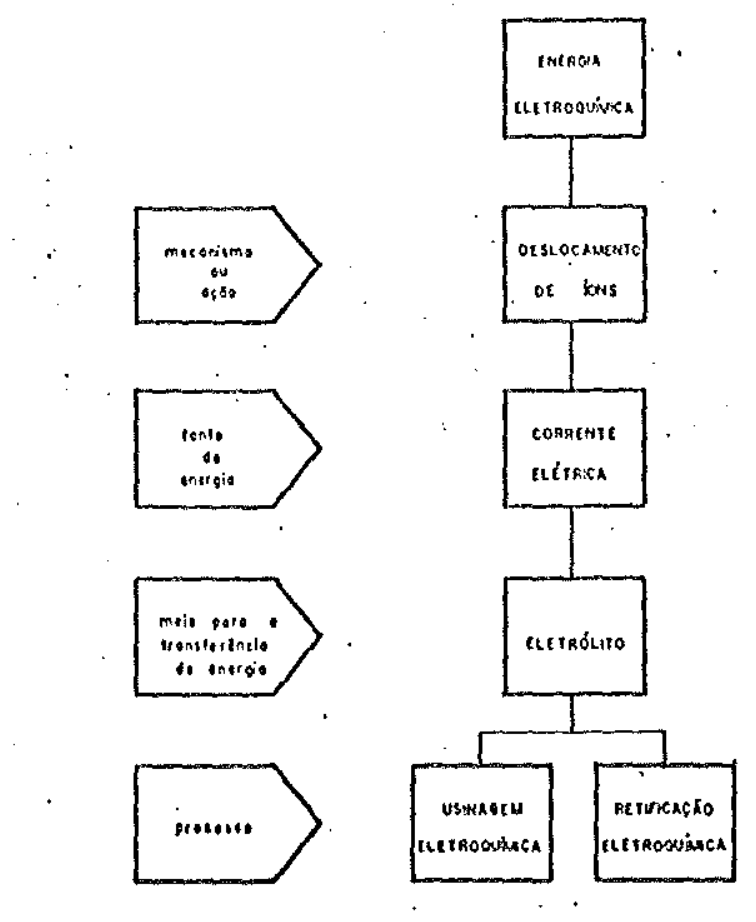

Fig.5.a- Processos não-convencionais de usinagem que empregam fundamentalmente a energia e letroquími ca ${ }^{2}$

Finalmente, na figura 5 b esboça-se o processo de remoção do material utilizando a energia química:

- usinagem química, UQU (chemical machining, CHM) . 

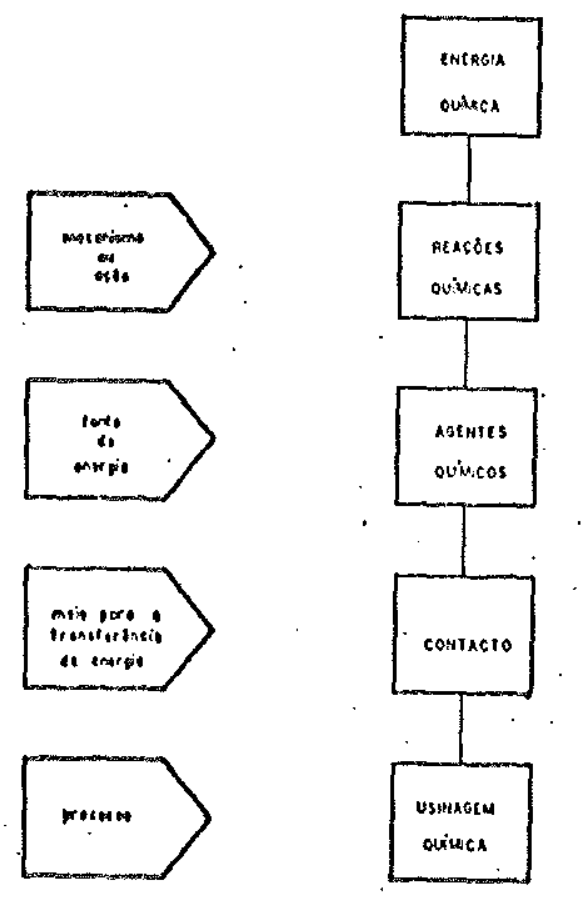

Fig.5.b- Processos não-convencionais de usinagem que empregam fundamentalmente a energia química ${ }^{2}$

\subsection{Aspectos Gerais e Comparativos dos Processos Não- Convencionais de Usinagem}

Para melhor ilustrar os últimos desenvolvimentos da tecnologia não-convencional de usinagem, apresentam-se algumas tabelas de dados referentes aos principais proces sos não-convencionais de usinagem. Alguns dos valores indi cados baseiam-se em condições particulares de aplicação, tais como potencialidade do equipamento, operações específicas, classes de materiais, custos médios etc. Isso se faz necessário ao confronto entre esses processos, esboçan do-se, dessa maneira, parâmetros de aplicações e limitações relativas, sob prismas semelhantes, para maior clareza de análise. 
Tab. 2.1 - Parâmetros físicos de alguns pro cessos não-convencionais de usi= nage $m^{3}$

\begin{tabular}{|c|c|c|c|c|c|}
\hline proctriso & TENSĀO $|V|$ & CORRERTE(A) & POTẼNCIA (W) & "OAP" $(\mathrm{mm})$ & $\begin{array}{l}\text { MEIO } \\
\text { rLUIDICO } \\
\text { INTERPOSTO }\end{array}$ \\
\hline UEO & 10 & $10000 \mathrm{cc}$ & 100000 & 0,20 & $\begin{array}{l}\text { Hequido } \\
\text { ontrostlico }\end{array}$ \\
\hline UPL & 100 & $500 \mathrm{cc}$ & 50000 & 7.5 & $\begin{array}{l}\text { orpōnio } \\
\text { hidrosomion }\end{array}$ \\
\hline UEE & 45 & $60 \begin{array}{c}c c \\
\text { pulsodo }\end{array}$ & 2700 & 0.025 & $\begin{array}{l}\text { liquisiso } \\
\text { dielófrico }\end{array}$ \\
\hline UUS & 220 & $12 \mathrm{co}$ & 2400 & 0,25 & $\begin{array}{l}\text { obrasivo } \\
\text { om doua }\end{array}$ \\
\hline UQU & - & - & - & - & $\begin{array}{c}\text { lifquido } \\
\text { quimico }\end{array}$ \\
\hline UJA & 110 & $1,5 \mathrm{co}$ & 250 & 0,25 & $\begin{array}{l}\text { abrosive } \\
\text { om sós }\end{array}$ \\
\hline ULA & 4500 & - & $\begin{array}{c}2 \text { med } \\
2000 \mathrm{mdx}\end{array}$ & 150 & s \\
\hline UFE & 10 & 0,001 pulsado & $\begin{array}{c}150 \text { méd } \\
2000 \text { móx }\end{array}$ & 100 & vócuo \\
\hline
\end{tabular}

Definem-se, inicialmente, alguns parâmetros físicos significativos desses processos na Tabela 2.1: tensão, corrente, potência, distância entre a ferramenta e a peça usinada ("gap") e o meio fluídico em que a usinagem se realiza.

Apenas a usinagem química prescinde do uso da $\underline{e}$ nergia elétrica, já que remove material por meio de reações químicas devido a um ataque ácido à peça. Os demais processos, ao contrário, utilizam uma fonte seja de corrente contínua, seja de corrente alternada. A usinagem com laser utiliza níveis de tensão da ordem de, pelo menos, $4.500 \mathrm{~V}$; por outro lado, os mais baixos níveis de tensão são utilizados pelos processos de eletroerosão ( $45 \mathrm{~V}$ ), eletroquímico $(10 \mathrm{~V})$ e por feixe eletrônico $(10 \mathrm{~V})$. Tais dados, como também todo o conjunto apresentado na Tabela 2.1, podem flutuar bastante no entorno daqueles valores, que não são fixos, mas dão uma ordem de grandeza represen tativa dos parâmetros físicos do processo. 
Em termos de corrente, tanto a usinagem por feixe eletrônico como por eletroerosão utilizam corrente pulsada, com valores eficazes situados em 0,001 e $60 \mathrm{~A}$, respectivamente; as usinagens com plasma e eletroquímica, corrente contínua com magnitudes médias de 500 e $10.000 \mathrm{~A}$, respectivamente; a usinagem por ultra-som e por jato abrasivo empregam corrente alternada com valores eficazes situando-se em 12 e $1,5 \mathrm{~A}$, respectivamente. A usinagem com laser utiliza una fonte de tensão para ionizar o plas ma do gás, permitindo a emissão de um feixe de luz coeren te que, incidindo na peça, provoca erosão - este processo não utiliza, portanto, corrente elétrica no mecanismo de remoção de metal nem na fonte de energia.

No que diz'respeito à potência necessária para - processo, salientam-se as usinagens eletroquímica(100.000W) e com plasma ( $50.000 \mathrm{~W})$, por un lado, e as usinagens com laser (2 W, em média), por feixe eletrônico (150 W, em mé dia) e por jato abrasivo $(250 \mathrm{~W})$. Os processos eletroerosivo e ultra-sônico exigem níveis de potência na faixa de 2.700 e $2.400 \mathrm{~W}$, respectivamente, enquanto o fresamento convencional situa-se nessa faixa (figura 6).

Em uma época em que os custos relacionados à energia são mais e mais ponderáveis, esse é um dado muito importante e que favorece sobremaneira a utilização dos processos não-convencionais, exceto a UEQ e a UPL.

Apenas três processos utilizam normalmente um "gap" relativamente grande: usinagens com laser (150 mm), por feixe eletrônico $(100 \mathrm{~mm})$ e com plasma $(7,5 \mathrm{~mm})$. o meio fluidico interposto na usinagern por laser é normalmente $o$ ar, podendo ser, no entanto, qualquer tipo de fluí do, ao conträrio dos processos eletroquímicos e por eletroerosão que necessitam, pela ordem, de um líquido eletrolítico e dielétrico para possibilitar a usinagem.

A Tabela 2.2 apresenta alguns dados tecnológicos da usinagem propriamente dita: velocidade de remoção 
de material, controle dimensional, acabamento superficial. e profundidade a partir da qual se acentua a possibilidade de alterações superficiais na peça usinada.

Tab. 2.2 - Dados de usinagem de alguns processos não-convencionais ${ }^{3}$

\begin{tabular}{|c|c|c|c|c|}
\hline procenso & $\begin{array}{l}\text { VELOCIOAOE } \\
\text { OE REMOSAOO } \\
\text { OE MATERIAL } \\
\left(\mathrm{mm}^{3} / \mathrm{min}\right)\end{array}$ & $\begin{array}{l}\text { TOLERÂMCIA } \\
\left(\mu_{m}\right) \\
\end{array}$ & $\begin{array}{l}\text { ACABAMENTO } \\
\text { BUPERFICIAL } \\
\text { (NE CLA) }\end{array}$ & $\begin{array}{l}\text { PROFUNDIDADE } \\
\text { DE ALTERAGAOO } \\
\text { SUPEAFICIAL } \\
(\mu \mathrm{m})\end{array}$ \\
\hline UEO & 15000 & 50 & $0,1-2,5$ & 5 \\
\hline UPL & 75000 & 125 & muito rugose & 500 \\
\hline UEE & $800-3000(*)$ & 15 & $\begin{array}{r}0,2-10 \\
2,5-30(*) \\
\end{array}$ & $125-250(*)$ \\
\hline UUS & 300 & 7,5 & $0,2-0,5$ & 25 \\
\hline UQu & 15 & 50 & $0,5-2,5$ & 5 \\
\hline UUA & $10-15$ & 50 & $0,5-1,2$ & 2,5 \\
\hline ULA & 0.1 & 25 & $0,5-1,2$ & 125 \\
\hline$U L A P$ & $1-15$ & 35 & $0.5-1.5$ & 200 \\
\hline UPE & 1.6 & 25 & $0,5-2,5$ & 2.50 \\
\hline $\begin{array}{c}\text { USINAGEM } \\
\text { CONVENCIONAL }\end{array}$ & 60000 & 50 & $0,5-5,0$ & 25 \\
\hline
\end{tabular}

: (B) encosis.

Assim, a usinagem com plasma caracteriza-se por uma velocidade de remoção de material alta $\left(75.000 \mathrm{~mm}^{3} /\right.$ /min) - supera até mesmo aquela obtida pelo fresamento convencional $\left(60.000 \mathrm{~mm}^{3} / \mathrm{min}\right)$. Ela é cinco vezes maior que a quela obtida pela usinagem eletroquímica $\left(15.000 \mathrm{~mm}^{3} / \mathrm{min}\right)$ e cinco vezes maior que a da usinagem por eletroerosão, no regime de desbaste $\left(3.000 \mathrm{~mm}^{3} / \mathrm{min}\right)$ - esta, em regime de semi-acabamento, atinge $800 \mathrm{~mm}^{3} / \mathrm{min}$. A usinagem por eletroerosão, contudo, propicia um bom acabamento superficial e tolerâncias reduzidas, provocando uma modificação estrutural em uma delgada camada externa do material de espessura próxima a $150 \mathrm{micra}$. Observem-se as baixas velo cidades de remoção de material obtidas pelas usinagens 
com laser $\left(0,1 \mathrm{~mm}^{3} / \mathrm{min}\right)$ e por feixe eletrônico $\left(1,6 \mathrm{~mm}^{3} /\right.$ /min), destinadas a aplicações bem específicas, no presen te. A usinagem com laser de alta potência (ULAP), por outro lado, atinge níveis mais altos de velocidade de remoÇão de material $\left(15 \mathrm{~mm}^{3} / \mathrm{min}\right)$, mas em detrimento das tolerâncias de fabricação.

A Tabela 2.2 evidencia, dessa maneira, a alta velocidade de remoção de material na usinagem com plasma, a qual supera, nesse aspecto, o fresariento convencional; no entanto, o acabamento superficial da peça usinada por aquele processo é deveras rugoso. Salientan-se, ainda, as usinagens eletroquímica e por eletroerosão, com melhores graus de acabamento superficial e tolerâncias dimensionais, apesar da usinagem ser bem mais demorada que a supracitada.

A Tabela 2.3 indica as possibilidades de usinagem segundo diversas operações: microfuração, furações cega e passante, execução de cavidade e de contorno superfi cial. Uma vez mais, destacan-se os processos eletroerosi vo e eletroquímico, cuja gama de aplicações é muito boa, bastante versátil. A.lém daquelas listadas na Tabela 2.3, as usinagens eletroerosiva e eletroquímica se prestam a serviços especiais como, por exemplo, fabricação de pás de turbinas, agulhas hipodérmicas, peças de carburadores etc. Os demais processos destinam-se a aplicações mais es pecíficas, muito enbora, abranjam também os materiais nãometálicos, aos quais não se aplicam os dois processos aci ma mencionados, como será mostrado nais adiante.

Na microfuração de peças destacam-se as usinagens com laser, feixe eletrônico, química e por eletroero são. Na usinagem de furos de pequeno diâmetro e comprimen to superior a vinte vezes esse diâmetro, dois processos são os mais indicados: o eletroquímico e o eletroerosivo. Apenas a usinagem química, devido às suas próprias características de remoção de material, não se pres 
Tab. 2.3 - Aplicações de forma de alguns processos não-convencionais de usinagem ${ }^{3}$

\begin{tabular}{|c|c|c|c|c|c|c|c|c|}
\hline \multirow{2}{*}{ Drocessiso } & \multirow{2}{*}{$\begin{array}{l}\text { MICRO- } \\
\text { FURACío }\end{array}$} & \multicolumn{2}{|c|}{ furasão } & \multicolumn{2}{|c|}{ EXECUCÁO DE CAVIDAOE } & \multirow{2}{*}{$\begin{array}{l}\text { CONYOANO } \\
\text { SUPEAFICIAL } \\
\end{array}$} & \multicolumn{2}{|c|}{ COATE passatate } \\
\hline & & $1 / 0 \leq 20$ & $1 / 0>20$ & se precisio & normol & & roo & profindo \\
\hline UEQ & - & $B O A$ & $B O A$ & ACEITÁVEL. & $B O A$ & BOM & BOM & BOM \\
\hline UPL. & - & ACEITÁVEL & - & RUIM & RUIM & - & $80 \mathrm{M}$ & $80 \mathrm{M}$ \\
\hline UEE & ACEITÁVEL & $B O A$ & ACEITÁVEL & $B O A$ & $B O A$ & ACEITÁVEL & $\operatorname{Bom}(*)$ & $\operatorname{som}(*)$ \\
\hline UUS & - & BOA & RiUIM & $B O A$ & $80 A$ & PUAM & Ruim & - \\
\hline vou & ACEITÁVEL. & - & - & RUIM & ACEITÁVEL & - & BOPA & - \\
\hline UJA & - & ACEITÁvEL. & RUIM & RUIM & ACEITÁVEL & - & BOM & - \\
\hline ULA & $B O A$ & ACEITÁVEL & RUIM & RUIM & RUIM & - & som & ACEITÁVEL \\
\hline UFE & ACEITÁVEL. & ACEITÁVEL & RỤIM & RUIM & RUIM & - & BOM & ACETTÁVEL \\
\hline
\end{tabular}

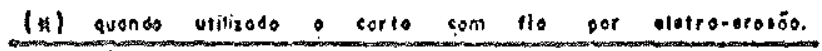

ta à fabricação de furos relativamente profundos. Todos os processos não-convencionais analisados podem ser utili zados na usinagem de cavidades, sendo que os mais indicados são os processos de ultra-som, eletroerosão e eletroquímico. Apenas estes três aplicam-se às operações de con torno supericial.

A aplicabilidade dos processos não-convencionais de usinagem aos diferentes materiais mais utilizados industrialmente, metảlicos ou não-metálicos, é objeto de análise na Tabela 2.4. Dentre os materiais e ligas metáli cas, selecionaram-se o aço, o alumínio, o titânio, superligas e refratários; dentre os materiais não-metálicos, os de maior uso corrente, ou seja, cerâmica, plásticos e vidro.

Vê-se, pela análise da Tabela 2.4 , que a possibilidade de utilização dos processos não-convencionais de 
Tab. 2.4 - Aplícabilidade de alguns processos não-convencionais de usinagem aos materiais mais utilizados na indús trìa mecânica ${ }^{3}$

\begin{tabular}{|c|c|c|c|c|c|c|c|c|}
\hline & \multicolumn{5}{|c|}{ METAIS E LIGAS METÁLICAS } & \multicolumn{3}{|c|}{ NÄO-METÁLICOS } \\
\hline crocosso & Afo & ALUBMIEIO & SUPERLIOAS & 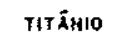 & REFAATARIOS & CERÃHICAS & PLAsricos & VIORO \\
\hline UEQ & BOA & ACEITAVEL & $80 A$ & ACEITAYVL & ACEITAvel & HAPLICAVEL & IHAPLICAVEL & IHAPLIC iVEL \\
\hline UPL. & BOA & DOA & BOA & ACEIT ÁVEL & RUIM & IHAPLICÁVEL & คU!M & IHAPLICÁvEL \\
\hline UEE & 801 & ACEITiVEt & Bon & BoA & BOA & IMAPLICAVEL & IMAPLICÁVEL & INAPLICÁVEL \\
\hline UUS & ACEITÁVEL & RUIM & RUIM & AcEitínel & BOA & BoA & ACEITAVEL & $80 \mathrm{~A}$ \\
\hline vou & OOA & Bot & AcEITÁVEL & ACEITAVEL & RUIK & RUIM & AUIM & ACEITÁVEL \\
\hline UJA & ACETTAVEL & Aceitível. & Bor & ACEITÁVEL & BOA & BOA & ACEITÁVEL & Bod \\
\hline$U L_{A} A$ & ACEITAVEL & AcEItives & ACEITÁvel & ACETÍVEL & คuIM & BOA & ACEITÁvel & ACEITÁVELL \\
\hline UFE & Aceriävel & ACEITÁVEL & Aceirível. & aceitível & $D O A$ & sod & Aceirível & ACEITÁvel. \\
\hline
\end{tabular}

usinagem $\vec{e}$ muito ampla e complementa as alternativas apre sentadas pela usinagem convencional. Eles se aplicam a to dos os metais e ligas metálicas, uns com melhor proprieda des que outros; salientam-se, nesse aspecto, as usinagens por eletroerosão, eletroquímica, com plasma e química. Aos materiais não-metálicos mais empregados, como os cerâ micos, plásticos e vidro, não se aplicam os processos ele troerosivo e eletroquímico; recomendam-se, nesse caso, as usinagens por ultra-som, jato abrasivo, laser e feixe ele trônico.

A compreensão das tabelas apresentadas é de fun damental importância à escolha correta dos equipamentos e processos destinados a certas linhas de produção, bem assim aos materiais a serem processados. Longe de serem com 
pletas, elas apenas emolduram o quadro da tecnologia nãoconvencional de usinagem; o painel completo é pintado com o estudo minucioso de cada um deles, o que foge ao escopo do presente trabalho.

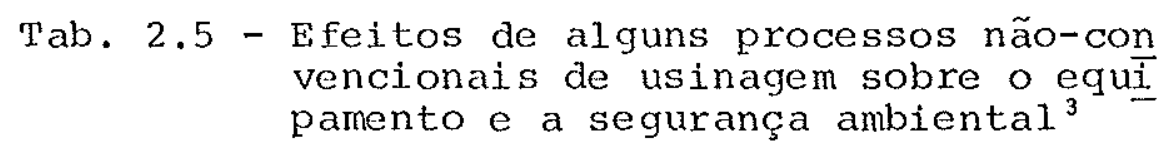

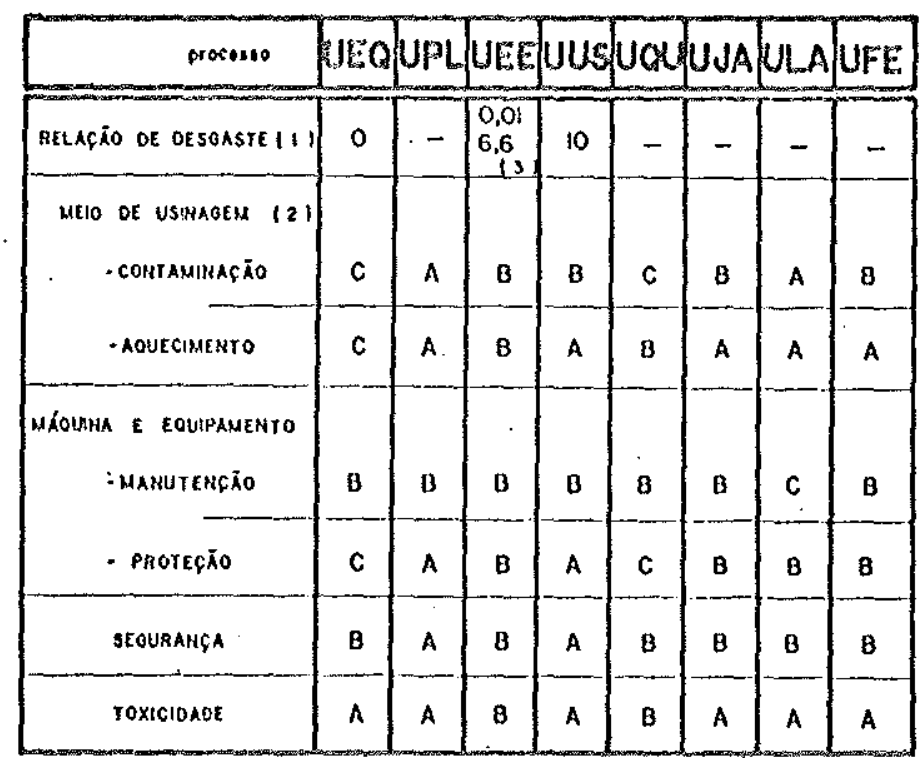

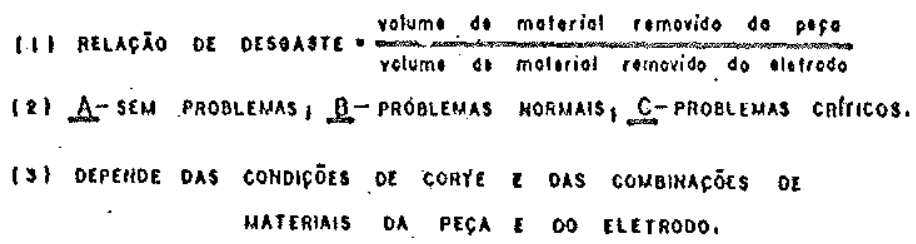

E característica comum a todos os métodos nãoconvencionais de usinagem um maior consumo de energia em relação aos métodos convencionais. Sobre isso, um confron to econômico, nos dias atuais, posiciona-se a favor dos métodos convencionais na usinagem de materiais de baixa e média resistência mecânica e de formas correntemente utilizadas na indústria, como superfícies cilíndricas, pla- 
nas, cônicas etc. Isso é enfatizado na Figura 6 , que representa graficamente as velocidades de remoção de material versus as potências necessárias aos processos em anā iise.

\section{PorẼnCIA (W)}

s

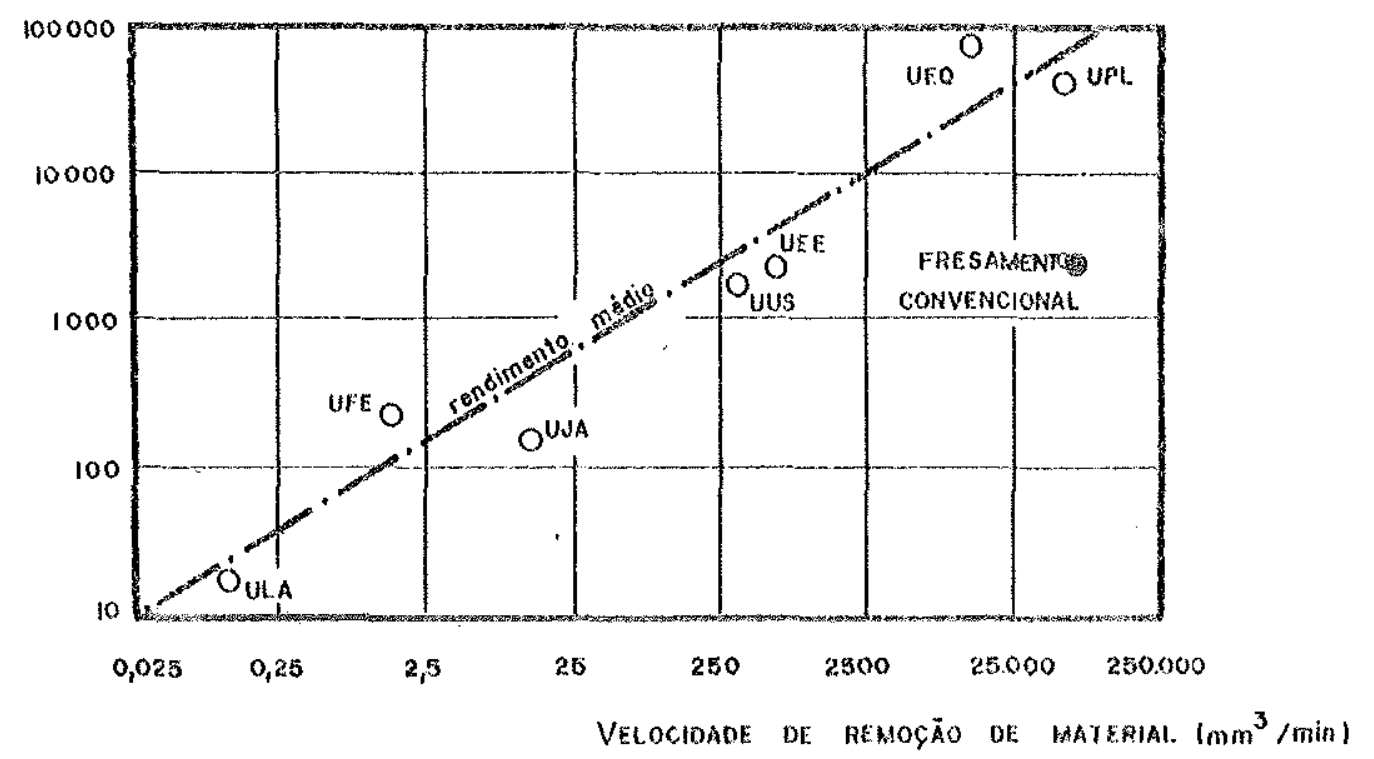

Fig. 6 - Potência necessária à remoção de materia.l através de alguns processos nãoconvencionais de usinage ${ }^{3}$

Levando-se em conta, por outro lado, materiais de alta resistência, peças com paredes delgadas, matrizes de formas intrincadas, furos de pequeno diâmetro e boa profundidade, e nível de especialização da mão-de-obra uti lizada na operação do equipamento, é patente a supremacia dos métodos não-convencionais de usinagem já nos dias de hoje, apesar de serem muito mais novos que os processos tradicionais de usinagem. 
Alguns efeitos dos processos em tela sobre o equipamento e a segurança ambiental são apresentados na Tạ bela 2.5. Pode-se ver no item "relação de desgaste" entre - ferramental utilizado e a peça usinada ser este um problema crucial para os processos por eletroerosão e ultrasom, dependendo das condições de usinagem.

No processo químico, a contaminação do ácido de trabalho afeta a sua concentração, bem como as condições de usinagem; no processo eletroquímico, além disso, o aquecimento do fluido prejudica a acuracidade do processo, exigindo, por isso mesmo, que a temperatura do banho eletrolítico seja bem controlada. Os demais tipos de usinagem não-convencional não apresentam problemas críticos re lacionados ao meio fluidico de serviço.

Na usinagem por eletroerosão, o sistema de filtragem do fluido dielétrico de serviço nem sempre é eficiente, mas a experiência tem mostrado que, dentro de certos limites, a contaminação do fluido dielétrico favorece as condições de usinagem, conferindo-lhe uma melhor estabilidade.

A manutenção dos equipamentos não exige cuidados especiats em relação äqueles tomados com as mäquinas operatrizes convencionajs, exceção feita ao equipamento empregado na usinagem com laser, pela sua sofisticação. Nos processos químico e eletroquímico, as partes em conta to com o fluido de trabalho têm que ser protegidas do ata que ācido.

E necessário que se tomem algumas precauções pạ ra evitar acidentes ou intoxicações devido à operação dos equipamentos de usinagem não-convencional. Isso inclui as normas relativas à segurança do trabalho para máquinas de uso corrente, salvo nos casos em que o fluido de trabalho é tóxico, como nas usinagens química, eletroquímica e por eletroerosão.

Tomando-se por base as faixas de custos médios correntes no mercado internacional e as peculiaridades de 
cada processo, elaborou-se a Tabela 2.6, com a finalidade de apresentar uma ordem de grandeza dos aspectos econômicos de cada un dos processos em apreço.

A usinagem eletroquímica tem custo global mais elevado dentre todos os processos não-convencionais de usinagem, principalmente devido ao alto custo do equipamen to. No processo eletroerosivo, contudo, alto é o custo do ferramental e acessórios, sendo investimento de capital. relativamente baixo face à versatilidade do processo.

Tab. 2.6 - Custos relativos de alguns processos
não-convencionais de usinagem

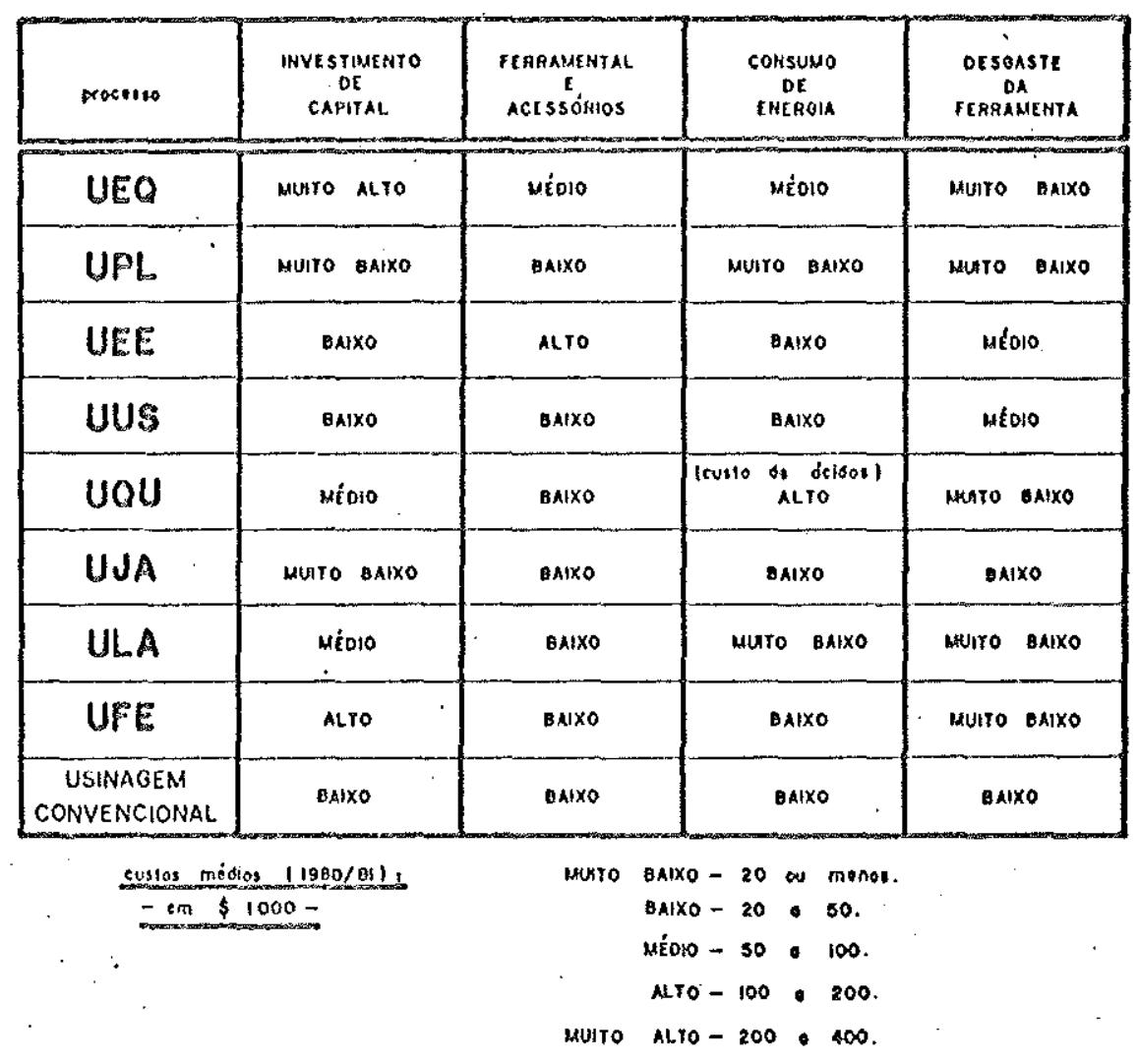

Na usinagem com laser de alta potência, o equipamento é muito caro, assim como na usinagem por feixe eletrônico. Todos os processos não-convencionais de usina- 
gem, como se pode constatar, têm custos mais elevados que os processos de usinagem convencionais. Entretanto, eles são competitivos quando confrontados aos processos de usi nagem por copiamento ou por comando numérico, dependendo, logicamente, do volume de peças a ser fabricado e dos materiais utilizados na fabricação dessas peças.

Dentre os vários processos não-convencionais de usinagem desenvolvidos, os mais adotados nas diversas aplicações industriais são os de eletroerosão, ultra-som e eletroquímico, notadamente o primeiro, que se tem constituído em uma alternativa prática, justificável e econômica nos parques industriais contemporâneos, a ponto de ser considerada, desde já, como um processo convencional competitivo.

Nos dias atuais, fundem-se ficção e realidade, calcadas principalmente no desenvolvimento de novas pesquisas aerospaciais, para prever uma evolução acentuada e interagente nos materiais através da pesquisa e fabrica ção, nos laboratórios espaciais, de novas e importantes 1 i gas, processos, dispositivos - toda uma tecnologia de van guarda, enfim. A escassez de recursos energéticos, frente ao crescimento da população mundial, está induzindo o homem a otimizar e/ou reprogramar os seus conceitos pré-estabelecidos. Esses dois eventos, em paralelo, tornam fácil admitir, para os próximos anos, a total consagração dos processos de usinagem não-convencionais ou, pelo menos, de alguns deles, como a usinagem por eletroerosão uma realidade palpável -, a usinagem eletroquímica, a usi nagem com laser etc. 
3. FUNDAMENTOS DA USINAGEM DE METAIS POR ELETROEROSÃO

\subsection{Histórico}

A erosão de metais por meio de descargas elétrí cas é conhecida desde meados do Século XVIII. A primeira constatação do fenômeno foi feita pelo cientista inglês Joseph Priestley, em 1762.

Isso, no entanto, foi um evento isolado e só no início deste século, em 1901, Bredig produziu soluções co loidais por "desintegração elétrica" utilizando um arco submerso em um 1íquido. Cinco anos mais tarde, Svedberg ${ }^{4}$ também conseguiu soluções coloidais a partix de descargas elétricas entre dois elétrodos convenientemente espaçados entre si e imersos em líquido dielétrico (Figura 7).

o circuito transformador de pulso desenvolvido por Svedberg possuia um capacitor $\mathrm{C}$, responsável pelo armazenamento de energia, permanentemente ligado a um trans formador principal, $L_{1}$. O capacitor era periodicamente descarregado através de um "gap" de descarga, $\mathrm{G}_{1}$, fazendo as 


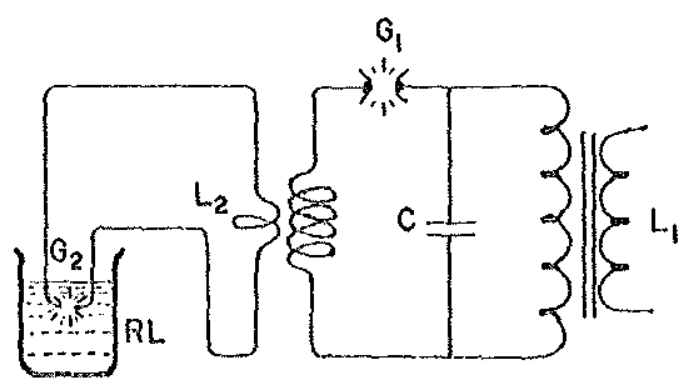

C - Copaciłor

$G_{1}, G_{2}-$ "Gdps" de descarga

$L_{1}$ - Transformador

$L_{2}$ - Bobina de alta-tensỡo, boixa corrente

RL - Reservatório de líquido dielétrico

Fig. 7 - Centelhamento com transformador secundário - circuito de svedberg"

vezes de um interruptor na bobina de alta tensão e baixa corrente, $\mathrm{L}_{2}$, de modo que o transiente das descargas pulsantes espaçadas no tempo, induziam a descarga no enrolamento de baixa tensão do transformador conectado ao "gap" de descarga $G_{2}$, formado pelo elétrodo de corte e a peça, produzindo dessa maneira metal coloidal e, paralelamente, uma erosão nos elétrodos.

Firmemente imbuído em produzir soluções coloidais a partix de descargas elétricas, Kohlschüter ${ }^{5}$, em 1919, desenvolveu e utilizou com absoluto sucesso o circuito da Figura 8 , que se assemelhava bastante a um circuito de relaxação empregado nas máquinas eletroerosivas dos nossos dias. Em suas pesquisas, amplamente difundidas nas revistas científicas especializadas da época, o alemão empregou água destilada como fluido dielétrico e cons tatou que a utilização de um circuito de descarga de míni ma indutância era o que melhor se prestava à remoção de metal dos elétrodos, sendo que o de polaridade positiva "desintegrava-se" bem mais que o de polaridade negativa. 


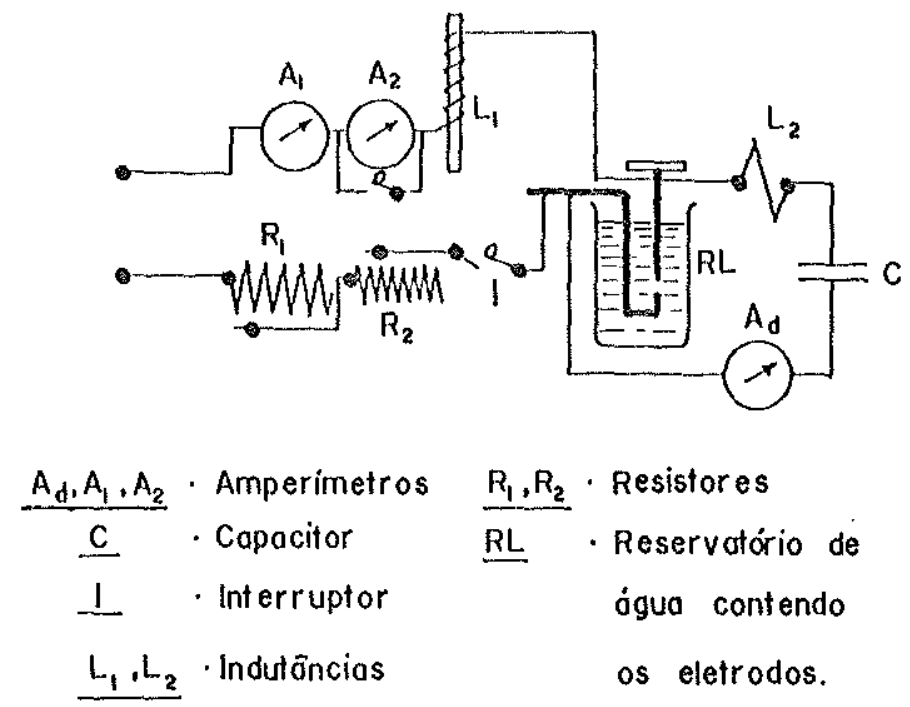

Fig. 8 - Circuito de relaxação desenvolvido por Kohlschüter ${ }^{5}$

Infelizmente, Kohlschütter estava exclusivamente interessado nos colóides produzidos e desprezou as demais potencialidades do circuito por ele desenvolvido.

Há uma patente inglesa de 1931 que descreve o funcionamento de uma serra de fita para o corte de metais que utiliza um arco contínuo. A fita é acionada a alta ve locidade, evitando-se dessa maneira o superaquecimento e a fusão do material de que é constituída, pelo arco elétrí co. Obviamente, no dispositivo inexiste ação de corte por meio de dentes, como no processo convencional.

Em 1934, Buss e seus colaboradores apresenta-ram, nos Estados Unidos da América do Norte, um trabalho sobre a utilização de descargas elétricas por meio de arcos interrompidos, originados de contatos vibratórios, pa ra produzir soluções coloidais destinadas ao tratamento 
de água para caldeiras a vapor. O seu dispositivo constava de um par de elétrodos que possuiam contato vibratório, sendo um deles um disco rotativo de material ferroso, estando ambos imersos na água de aljmentação da caldeira.

A Figura 9 mostra u'a máquina, seme thante a um torno mecânico, desenvolvida e utilizada em 1936 por Hols lag $^{6}$. Através dela, são gerados arcos de corrente contínua interrompidos, provenientes de um mau contato entre $\underline{u}$ ma peça rotativa e um elétrodo estacionário, no ar.

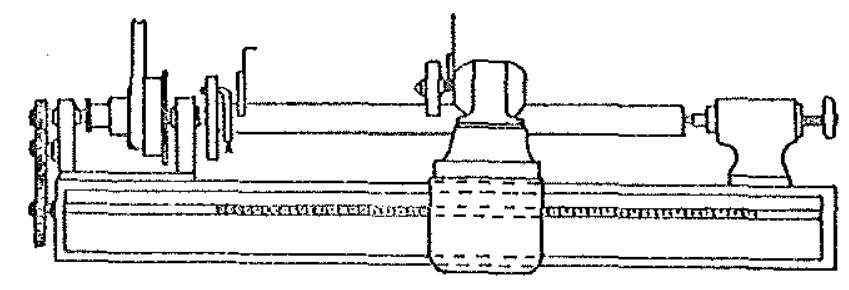

Fig. 9 - Mäquina de Holslag ${ }^{6}$

Nos seus experimentos,Hols lag ${ }^{6}$ observou que para obter uma superfície bem plana, deve-se ajustar a tensão entre o elétrodo e a peça, à metade daquela exigida para manter um arco estacionário entre esse elétrodo e a peça.

Uma serra circular que utiliza um arco elëtri co móvel. em operações de corte é descrita em uma patente inglesa datada de 1937. O dispositivo prevê alta rotação da serra, permitindo-lhe assim um bom resfriamento, enquan to a peça é aquecida à temperatura de fusão no ponto de corte pelo arco interrompido formado entre a borda da se $\underline{r}$ ra e a peça; não há ação de corte por meio de dentes, como no processo convencional. 
Em 1942, Burnett propôs a utilização de descargas de arcos interrompidos entre um elétrodo vibratório e uma peça banhada por um filuido estacionário, na remoção de brocas e machos quebrados no interior de peças. Em 1947, essa patente foi registrada na Inglaterra, seguida imedia tamente por diversas outras semelhantes.

Warwick projetou, em 1943, um dispositivo similar ao de Burnett, no qual um elétrodo vazado girava e ví brava simultaneamente, enquanto era resfriado por ar comprimido, produzindo assim arcos interrompidos. A partir de então, vários dispositivos chamados "desintegradores" foram desenvolvidos e comercializados.

Quando verificavam o desgaste de contatos inter ruptores, em 1943, os pesquisadores soviéticos B. R. Laza renko e N. I. Lazarenko constataram, analisaram e desenvolveram a extradordinária capacidade erosiva das descargas elétricas em um meio fluido, praticamente "redescobrin do" o trabalho de Kohlschütter, dando-lhe asas e aplicabi lidade imediata já na II Guerra Mundial, através da fabri. cação de artefatos bélicos que utilizavam materiais de al ta resistência.

Nascia aí, efetivamente, a usinagem por eletroerosão.

A "Bendix Aviation Corporation" desenvolveu nos Estados Unidos da América do Norte, em 1945, patenteando-o na Inglaterra, um dispositivo que empregava um arco elétrico para o balanceamento automático dos corpos em rotaÇão, tais como os rotores de giroscópios utilizados nos a viões.

Rudorff, em 1950, registrou a primeira patente na Inglaterra e, quiçá, no mundo, descrevendo o moderno processo de corte por eletroerosão com um fluido dielétri co passando através da zona de corte. Cinco anos depois, já surgiam máquinas que utilizavam um servocomando eletro -hidráulico do cabeçote, cujo sistema foi imediatamente a dotado pela maioria das máquinas a partir de então. 
A utilização de um fio que se move continuamen te como um elétrodo no processo de usinagem por eletroero são foi feita pela primeira vez na Rússia, na metade da década de cinquenta. o processo foi utilizado, alguns anos mais tarde, na Inglaterra e Estados Unidos da América do Norte, na produção de pequenas ranhuras em pulsadores de neutron requeridos pela respectiva indústria atômica, e por outras, na preparação de amostras metalúrgicas.

A franca aceitação do processo eletroerosivo en sejou novos desenvolvimentos, como a introdução, em 1957, do porta-clétrodo magnético e a apresentação, em 1959, dos geradores de impulsos controlados, totalmente transistori zados; em 1964, surgiu o primeiro gerador de impulsos iso energéticos, enquanto em 1968, foram incorporados às máqui nas de usinagem por eletroe rosão mandris guiados por mancais hidrostáticos, propiciando-lhe grande precisão de guia e melhoria do funcionamento do sistema de avanço ser vocomandado. .

Em 1972, surgiu mais uma inovação de destaque, ao ser desenvolvido e apresentado comercialmente um monitor que analisa o desempenho de usinagem, corrige automaticamente alguns parâmetros de regulagem e dá diretrizes que permitem ao operador otimizar as condições dessa usinagem.

Em 1973, surgiu a máquina de corte com fio por eletroerosão, acionada por comando numérico. Em 1976, já considerado naquele país um processo convencional de usinagem, foi testada com sucesso absoluto pela Raycon Corpo ration, nos Estados Unidos, uma linha de transferência au tomática assíncrona que utiliza máquinas de eletroerosão, em todas as suas estações, para a usinagem de pequenos fu ros, assegurando-1he alta repetibilidade e tolerâncias es treitas.

o aperfeiçoamento do processo de usinagem por $\underline{e}$ letroerosão, através de suas máquinas, equipamentos e si. temas de controle, continua. A cada dia, surgem novas i- 
déias e projetos de otimização, o que assegura a utilização em escala crescente do método em todo o mundo.

\subsection{Descarga Elétrica}

O fenômeno da descarga elétrica entre dois elétrodos apresenta diferentes características, conforme a natureza e condições do meio no qual estes se encontram. Distinguem-se, assim:

- descarga no vácuo

- descarga em gás muito rarefeito

- descarga em ar ou gás, à temperatura e pressão normais

- descarga em líquido dielétrico

- descarga em líquido eletrolítico.

Ao processo eletroerosivo dizem respeito os tipos de descarga acima sublinhados

\subsubsection{A Descarga Elétrica em um Meio Gasoso}

A descarga elétrica em um meio gasoso tem sido objeto de diversas pesquisas viabilizadas devido ao grande interesse que o assunto desperta no desenvolvimento da técnica moderna; ela é utilizada para produzir plasma sob condições de laboratório, bem assim para excitar a maioria dos "lasers" a gás, dentre outras aplicações.

A Figura 10 apresenta um diagrama INTENSIDADE DE CORRENTE x TENSÃO ELETRICA que auxilia a descrição das características fundamentais da descarga em um meio gasoso. Ao se aumentar paulatinamente a tensão entre os dois elétrodos, constata-se que a corrente também aumenta, segundo a Lei de Ohm (trecho OA do diagrama). Em seguida, quando os íons deslocados sob o efeito da tensão tornam-se iguais, em número, àqueles que se formam nesse espaço, 
a corrente se estabiliza (trecho $A B$ do diagrama). O valor da corrente depende, aqui, do fator ionizador do gás. Em condições normaịs, esse fator, sendo pequeno, ensejará um valor insignificante à corrente.

$$
\text { Quando a tensão atinge um determinado valor, }
$$

a velocidade de deslocamento dos íons torna-se tão grande que seus choques com as moléculas neutras arrancam os elé trons destas, provocando assim uma ionização complementar que, por sua vez, aumenta a intensidade de corrente entre os elétrodos (trecho BC do diagrama). Dá-se, aqui, uma ver dadeira descarga, acompanhada de um fenômeno de luminescência do gás, entre os elétrodos.
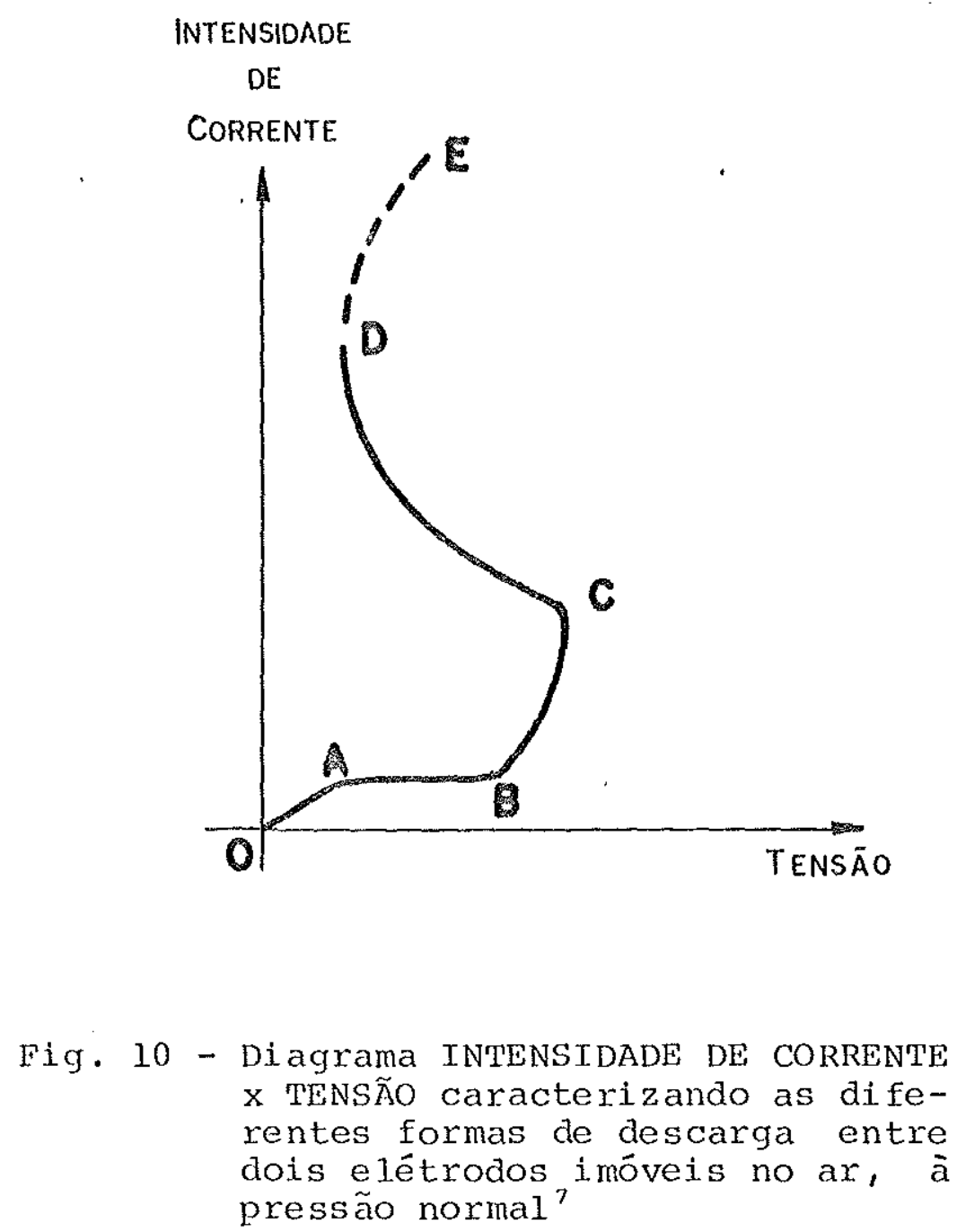
Até o ponto $\mathrm{C}$ do diagrama da Figura 10, há uma característica positiva da curva, ou seja, um aumento na tensão é sempre seguido por um aumento na corrente. A par tir de uma certa tensão-limite, porém, a resistência do meio é vencida, caracterizando-se uma nova forma de. descarga, espontânea - é a descarga por centelha (trecho CD do diagrama) - que se distingue por uma declividade negativa, no diagrama.

Com efeito, nesse caso, um aumento na corrente provoca uma queda de tensão, permitindo uma passagem maci ça da carga contida no circuito de alimentção em um tempo extremamente curto, da ordem de $10^{-4}$ segundo, ou menor. A qui, a descarga é inteiramente independente da natureza do circuito de alimentação e todo o fenômeno depende unicamente da quantidade de energi a acumulada nessa alimenta ção.

Se a potência da fonte de alimentação não for suficiente para manter o processo de descarga de forma contínua, a tensão entre os elétrodos, após a descarga, cai a um valor mínimo, fazendo com que a descarga cesse, devido à resistência imposta pelo meio situado entre os dois elétrodos. Se, ao conträrio, a potência da fonte de alimentação for suficiente para manter as condições de descarga, o processo se estabiliza sob a forma de um arco elétrico (trecho DE do diagrama).

A seção OA do diagrama é caracterizada por uma série de fenômenos que é utilizada principalmente pela eletrônica; as descargas da seção $\mathrm{BC}$ são frequentemente em pregadas na purificação de gases, coloração superficial de relevos complicados etc.; a zona $\mathrm{CD}$, das descargas bruscas e espontâneas, caracteriza as centelhas elétricas e, finalmente, a seção DE tem um largo campo de aplicação na soldagem de metais e ligas metálicas.

As descargas por centelhas elétricas que se for mam no ar ou em um gás qualquer não produzem efeitos sufí cientes sobre os elétrodos para serem utilizadas como um 
meio significativo de arrancamento de material. O fenômeno assume um aspecto totalmente diferente tão logo se mergulham os elétrodos em um meio dielétrico líquido. o processo físico da descarga torna-se extremamente mais complexo e surgem novos fatores importantes:

- uma grande concentração espacial da descarga, provocando uma destruição localizada nas superfícies dos elétrodos, cuja magnitude corresponde à energia da descarga;

- um efeito de polaridade, segundo o qual a ero são dos dois elétrodos dá-se de forma distinta, ou seja, a remoção de material do ânodo é, normalmente, maior que a do cátodo.

\subsubsection{A Descarga Elétrica em Líquido Dielétrico}

A descarga elétrica em um neio dielétrico líqui do se produz em consequência de uma ruptura da resistência imposta pelo meio à passagem da corrente elétrica. Di versos experimentos têm mostrado que se podem distinguir três fases essenciais dessa descarga:

- FASE pREparatória - sob a influência de um potente campo elétrico, durante um tempo da ordem de $10^{-7}$ a $10^{-8}$ segundo, o meio dielétrico ioniza-se entre os dois pontos mais pró ximos entre os elétrodos, ou seja, os picos mais salientes, que ultrapassam sensivelmente o plano médio teórico das superfícies que separam cátodo e ânodo. Tais picos, insignificantes sob o ponto de vista mecânico, têm variações de aproximação de 20 a $40 \%$ em relação à pequena distância que separa os elétrodos ("gap"). Uma ionização particularmente forte tem lugar, portanto, entre esses dois pontos, 
favorecendo a formação da descarga nesse lugar preciso, puntiforme, de modo que a formação simultânea de várias descargas torna-se praticamente impossível.

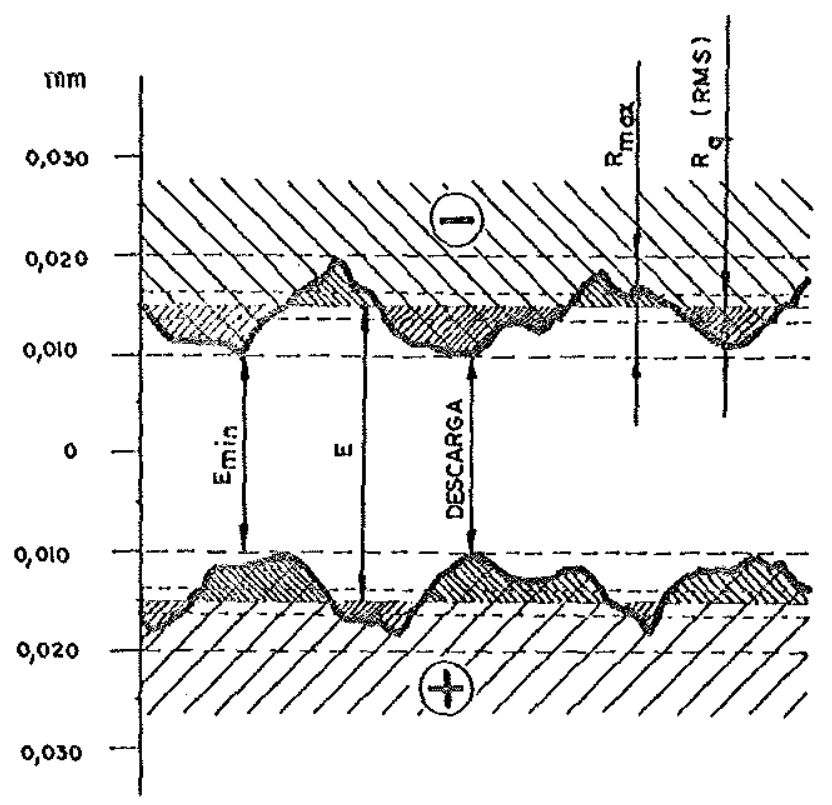

Fig. 11 - Corte longitudinal de dois elétrodos, aproximados à distância média eletroerosiva

A Figura 11 representa, a titulo de exemplo, em uma escala de 1 : 1000, guardadas as devidas proporções, as superfícies de dois elétrodos posicionados ä distância média de eletroerosão. Aqui, a rugosidade superficial média quadrática, $\underline{R}_{q}$ (RMS), caracteriza a qualidade mecânica da superfície, E indica o desvio médio das duas superfícies de resistência teórica; $E_{m I n}$ é a distância entre os dois pontos mais próximos entre os elétrodos; $\underline{R}_{\text {máx }}$ é o desvio entre as asperidades e os vales de uma mesma super fície; a flecha indicativa de "descarga" ressalta o local mais favorável para que haja uma descarga elétrica en tre os elétrodos, sob condições normais do "gap". 
- FASE DE DESCARGA PROPRIAMENTE DITA - passagem maciça de corrente devido à carga armazenada pelo circuito de alimentação e à formação de uma zona de plasma com temperatura entre 8.000 e $12.000^{\circ} \mathrm{C}$, na região ionizada. Quando a des carga eletroerosiva tem lugar, a temperatura do plasma atinge picos de até $50.000{ }^{\circ} \mathrm{C}^{9}$.

- FASE DE EXPULSÃO DO METAL REMOVIDO - tem início durante a fase anterior e continua após o fim da descarga. Os esquemas apresentados pela Figura 12, representam, de um modo sumário, as diversas etapas da descarga.

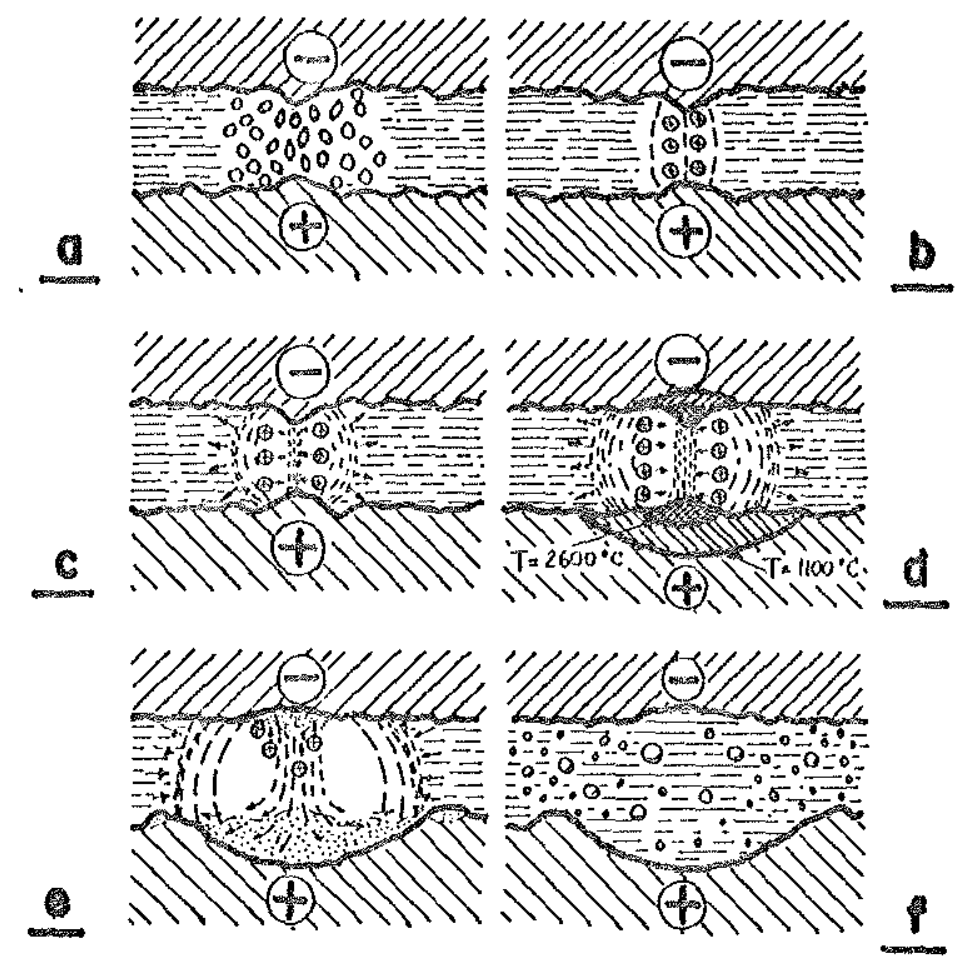

Fig. 12 - Representaçăo esquemática do fenômeno da descarga em um meio dielétrico líquido ${ }^{8}$

- Esquema a - una intensificação do campo elétrico entre as asperidades mais próximas, entre os dois elétrodos polariza e orienta as moléculas e os rons do fluido dielétrico, bem como as 
partículas sólidas que se encontram em suspensão no líquido de servíço.

- Esquema b - uma vez que a ionização do meio atinge um nível suficiente, formam-se canais de eleva da condutibilidade (os chamados "streamers"), facilitando a passagem da corrente de descarga e determinando o seu caráter de espon taneidade.

- Esquema c - como a resistência do meio, nesse lugar, cai bruscamente a um valor próximo de zero, a intensidade de corrente pode atingir valo res da ordem de milhares de Ampères, com um incremento da ordem de $10^{6}$ a $10^{8} \mathrm{~A} / \mathrm{s}$. O exa me espectrográfico da zona de descarga tem mostrado que o canal é constituído pelo plasma, pelo vapor dos metais de que são feitos os elétrodos e pelo gás resultante da decomposição química do dielétrico sob a ação da centelha elétrica.

- Esquema d - a passagem maciça da corrente ioniza mais ainda o canal e cria um campo magnético potente que atrai os íons para o eixo da descarga (efeito "pinça"); estes, por sua vez, comprimem novamente o feixe de corrente, exercendo sobre ele uma pressão importante, impelindo a temperatura a atingir os valores necessários à formação do plasma. Ao mes mo tempo, dada a extrema rapidez da formação da bolha gasosa, esta exerce uma pressão considerável sobre o líquido do "gap". A quantidade de calor desenvolvida pela des carga e concentrada nas asperidades dos dois elétrodos é suficiente para fundir uma parte e vaporizar outra do metal desses elé trodos. As linhas de temperaturas-limite, 
$2.600 \mathrm{e} 1.100{ }^{\circ} \mathrm{C}$, representadas na figura, correspondem aproximadamente à quantidade de metal. removida por vaporização e fusão, respectivamente.

- Esquema e - simultaneamente com os efeitos térmicós da descarga, esta última se manifesta sob a forma de um choque mecânico dos elétrons e do plasma "arrastado" por eles, em uma forma comparável ao choque de um projétil a uma velocidade extremamente elevada, cujo re sultado se manifesta pela expulsão do metal. fundido e vaporizado, descobrindo nesse lugar a cratera típica da descarga erosiva. o choque dos íons positivos contra a superficie do cátodo, que sofre iqualmente o efeito térmico da descarga, faz ejetar também um certo volume de metal, provocando um cer to desgaste no cátodo. No fim da descarga, devido à interrupção da fonte de energia, a pressão no interior da bolha de gās formada em redor do canal de descarga cai bruscamen te até um valor negativo, acontecendo um fenômeno similar à cavitação. o metal fundi do e vaporizado pela descarga é então varri do por um violento contrachoque hidráulico que intervém favoravelmente no processo de erosão, facilitando a limpeza dos resíduos da zona de descarga.

- Esquema $f$ - vê-se, aí, a cratera característica de uma descarga erosiva sobre o ânodo, de maiores proporções que aquela verificada sobre o cá todo. O material ejetado encontra-se sob a forma de esférulas, no "gap".

Como visto, o efeito de uma descarga eletroerosiva pode ser comparado ao de uma explosão que, por sua e 
nergia concentrada, ultrapassa - guardadas as proporções - aquelas produzidas pelos mais possantes explosivos...

o metal fundido e/ou vaporizado, ejetado da zona de descarga, recondensa-se em seguida no banho dielétrico do reservatório de serviço e assume a forma de colóides, cujas dimensões dependem dos parâmetros elétricos da descarga, das propriedades físico-químicas dos metais dos elétrodos e do líquido dielétrico.

Imediatamente após ser utilizada a energia de $\underline{u}$ ma centelha erosiva, o canal de contubilidade elétrica se refaz e o mesmo ciclo pode recomeçar para dar lugar à des carga seguinte, na região de asperidades mais próximas en tre os elétrodos.

A teoria eletrotérmica descrita é atualmente a mais aceita nos meios científicos que estudam o fenômeno da UEE. As teorias eletromecânica e termomecânica ${ }^{2}$ apresentam discordâncias frontais com resultados experimentajs obtidos e são, hoje, consideradas como obsoletas.

3.3. Aplicações Industriais do Processo de Usinagem por Descargas Elétricas

Há mais de trinta anos que o processo de usinagem por eletroerosão - UEE (EDM) foi "apresentado" oficialmente como um método de fabricação. Nos seus primeiros anos, a UEE foi referendada como a última palavra no campo da usinagem dos metais, e alguns pesquisadores mais otimistas predisseram que o processo tornaria, em pouco tempo, todos os demais métodos de usinagem obsoletos.

Essa primeira etapa, quando se extrapolava o fu turo do novo processo com base na sua versatilidade, fruto inequívoco do entusiasmo vigente na época de pós-guerra, fez com que se esquecessem a sua principal limitação: a velocidade de corte.

As velocidades de remoção de metal, em todos os processos de usinagem por descargas elétricas, são limita 
das por fatores inerentes ao próprio processo, como pode ser inferido pela análise acurada do fenômeno da descarga, na seção anterior.

Apesar da verdadeira bateria de ensaios encetados pelos fabricantes de máquinas eletroerosivas e dos so fisticados circuitos eletrônicos desenvolvidos até o presente, houve muito pouca evolução na velocidade de remoção de metal, dentro dos parâmetros de tolerância exigidos pela engenharia de fabricação. Esse fato pode ser facilmente averiguado confrotando-se os valores obtidos pelas máquinas modernas com aquelas de trinta anos atrás.

A experiência tem mostrado que se constatam progressos no processo de usinagem por descargas elétricas sempre que alguma idéi a nova demove os vínculos impostos pela errônea suposição de que esse processo substituirá quando, na verdade, ele complementará - com evidentes van tagens-todos aqueles desenvolvidos nas máquinas-ferramenta convencionais.

O processo eletroerosivo, contudo, tem aplicabi lidade muito boa no campo da usinagem de metais, particu larmente na fabricação de ferramentas, matrizes,peças del gadas e execuções de forma complicada, onde se firma cada vez mais. Tambëm tem tido boa aceitação na produção de $\underline{\text { u }}$ ros, em sistemas de alimentação de combustível de motores de automóveis e aviões, peças de relógio e de computador etc.

Os métodos atualmente aplicados são os seguintes :

$$
\begin{aligned}
3.3 .1 \text { - USINAGEM POR ELETRORROSÃO - UEE } & \text { (Electrical-Discharge Machining - EDM) } \\
3.3 .2- & \text { RETIFICAC̄̃O POR ELETROEROSÃO - REE } \\
& \text { (Electrical-Discharge Grinding - EDG) } \\
3.3 .3- & \text { SERRAMENTO POR ELETROEROSÃO - SEE } \\
& \text { (Electrical-Discharge Sawing - EDS) }
\end{aligned}
$$


3.3.4 - CORTE COM FIO POR ELETROEROSÃO - CFEE (Electrical-Discharge wire cutting EDWC) .

As Figuras de 13 a 24 ilustram as possibilidades do processo, empregadas atualmente ${ }^{9}$.

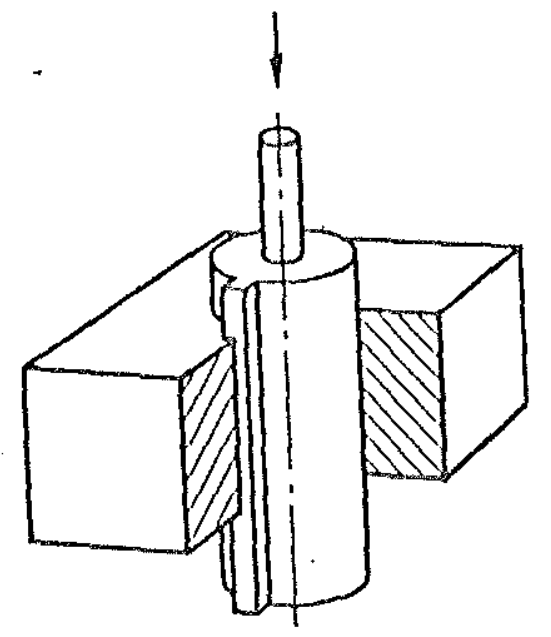

Fig. 13 - Furação passante por eletroerosão

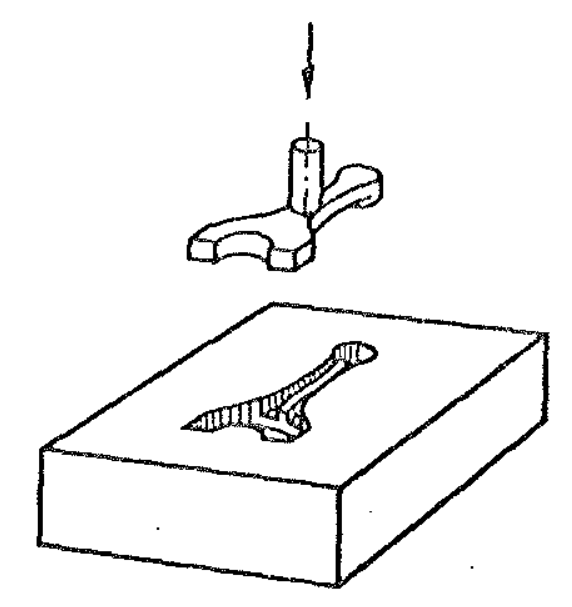

Fig. 15 - Furação cega por eletroe rosão

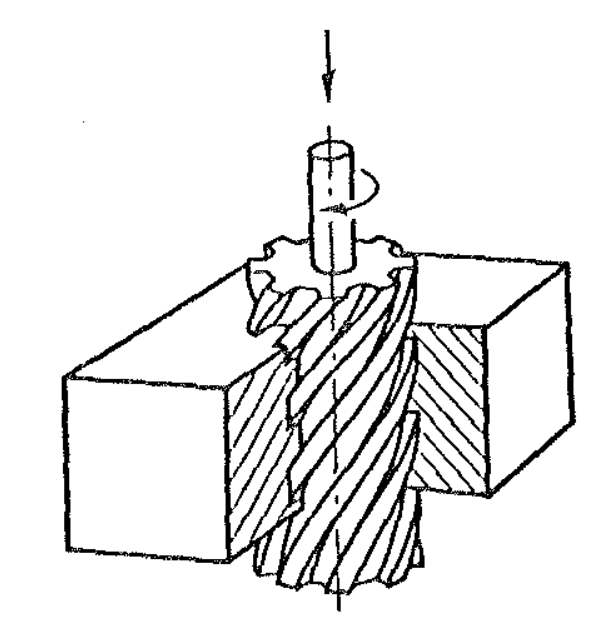

Fig. 14 - Roscamento por e letroerosão

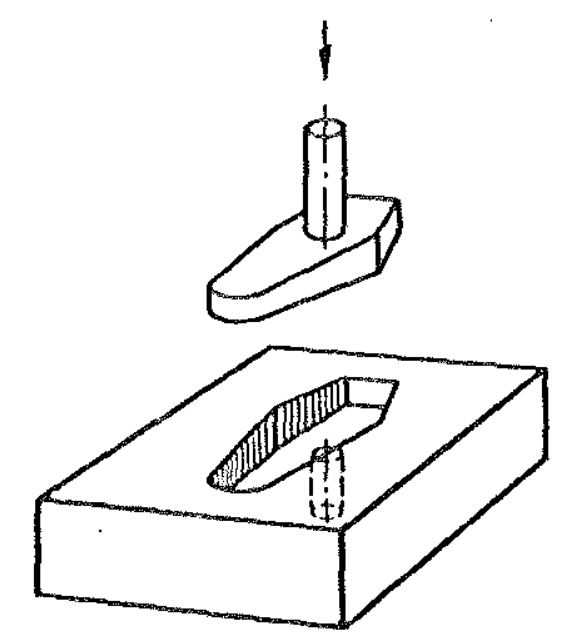

Fig. 16 - Furação cega, com orifício de lava vem 


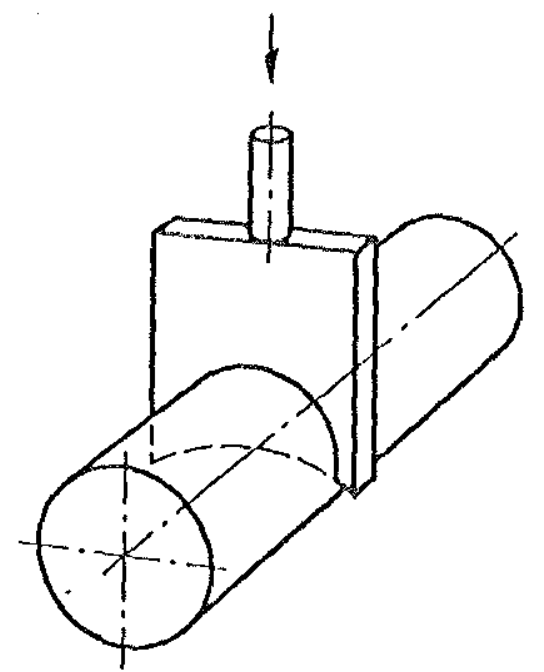

Fig. 17 - Corte com uma lâm na por eletroerosão

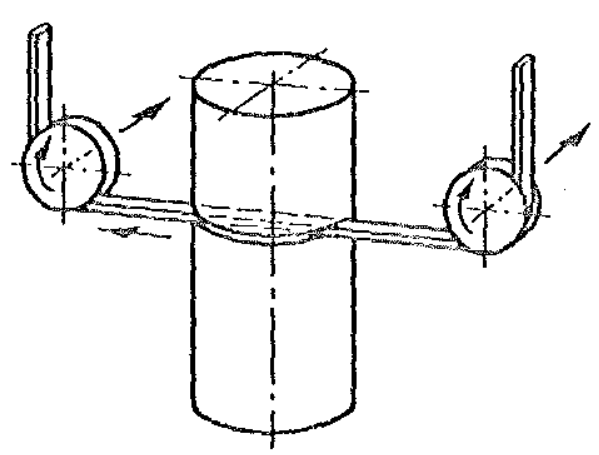

Fig. 19 - Corte com uma fita por eletroerosão

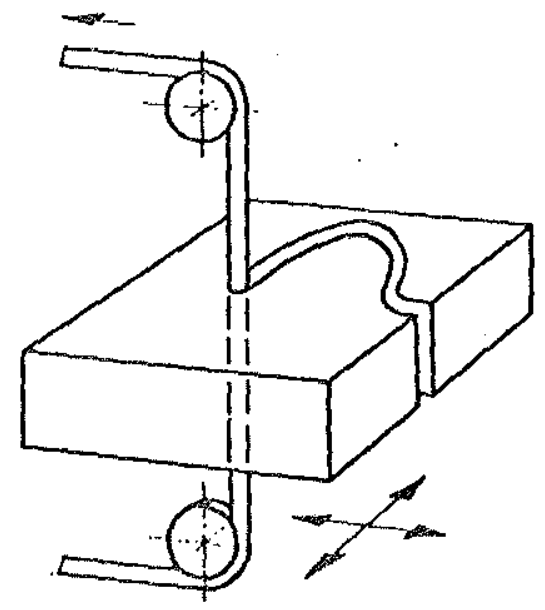

Fig. 18 - Corte com um fio por eletroerosão

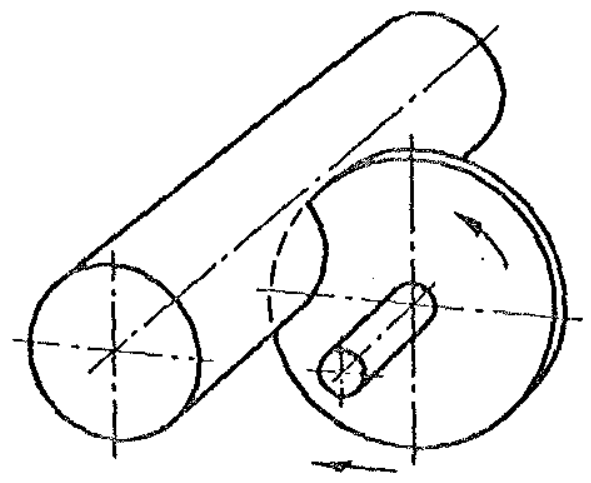

Fig. 20 - Corte com um dis co rotativo por eletroe ros ão 


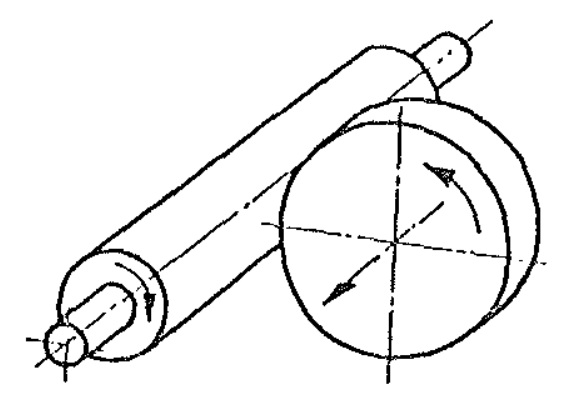

Fig. 21 - Retificação externa por eletroerosão

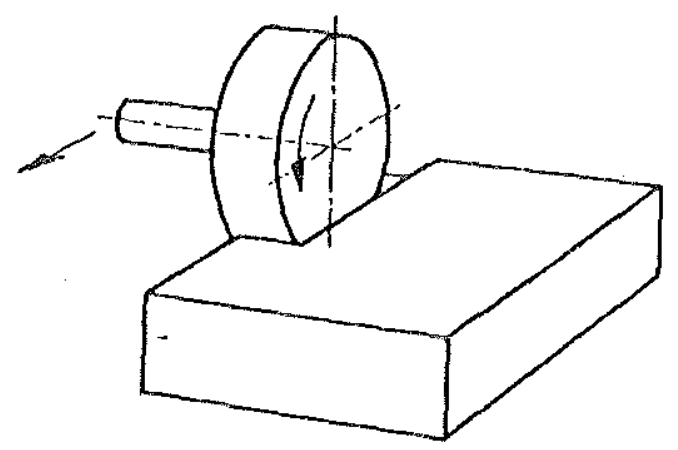
$\begin{aligned} & \text { Fig. } 23 \text { - } \text { Retificação plana } \\ & \text { por eletroerosão }\end{aligned}$

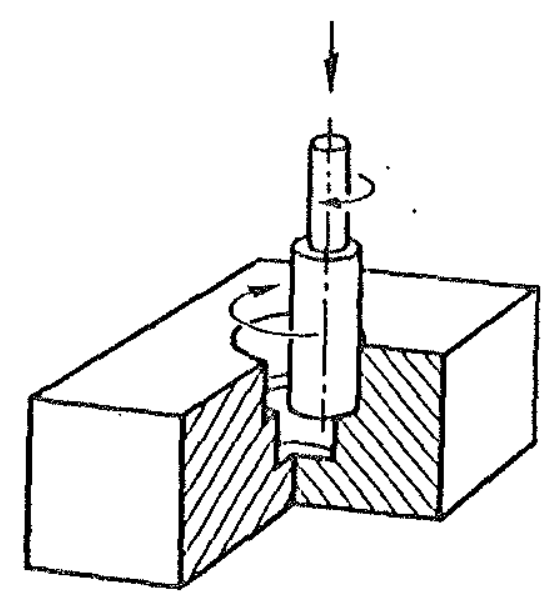

Fig. 22 - Retificação interna por eletro erosão

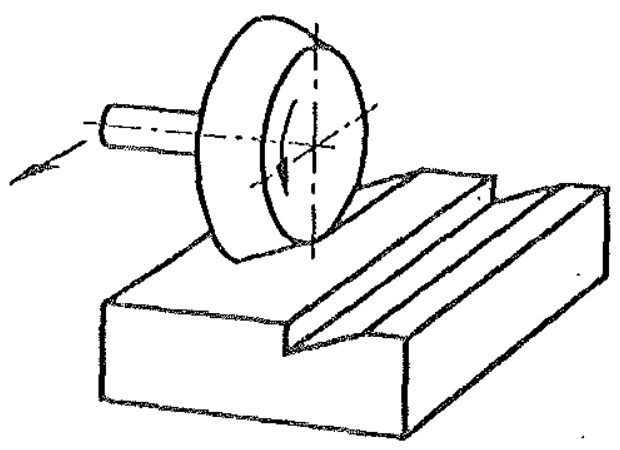

Fig. 24 - Retificação de perfil por eletroerosão

\section{3 .1 . Usinagem por Eletroerosão - UEE}

A usinagem por eletroerosão (UEE) é um método de produção de furos, ranhuras ou outras cavidades em materiais eletricamente condutores, por meio da remoção controlada de material através da fusão e vaporização provo- 
cada por centelhas elétricas a alta frequência (160 a 500 mil centelhas por segundo).

A descarga elétrica é produzida por pulsação controlada de corrente contínua entre a peça a ser usinada - geralmente, o ânodo - e o elétrodo-ferramenta - na maioria das vezes, o cátodo. A extremidade do elétrodo e a peça são separadas por uma distância que normalmente va ria entre 10 e $510 \mu \mathrm{m}$ ("gap"), dependendo da tensão de des carga, necessariamente superior a $20 \mathrm{~V}$, e são imersas ou banhadas por um fluido dielétrico, Figura 25 .

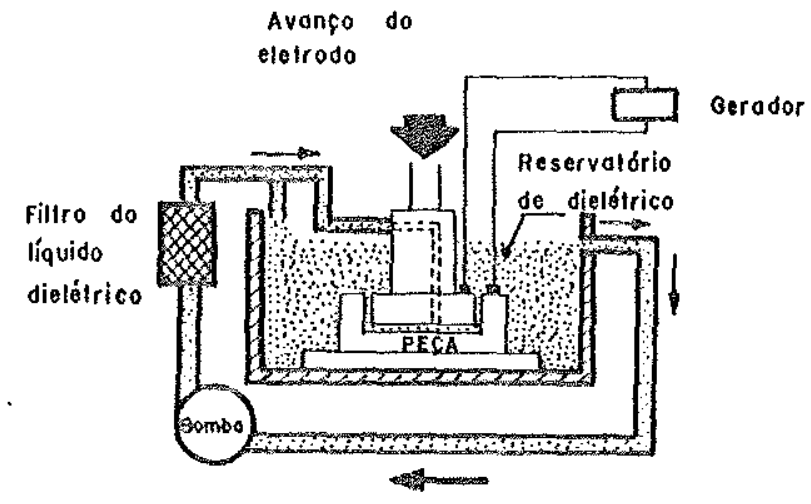

Fig. 25 - Esquema de funcionamento de u'a maqui na de usinagem por eletroerosão

o arrancamento de material é obtido, pois, por uma sucessão de descargas não-estacionárias, separadas umas das outras no tempo, ou seja, o fenômeno é unitário e períodico. Cada descarga produz bastante calor para fundir e/ou vaporizar uma micro-região da peça, deixando uma pequena cavidade ou cratera na sua superfície.

A principal vantagem desse processo é que ele permite a usinagem de geometrias irrealizáveis pelos méto dos clássicos de usinagem de metais e que exigiriam siste mas de copiamento e/ou comando numérico complexos e onero sos, além de pessoal altamente especializado. Tal vantagem é amplificada enormemente se a peça a ser trabalhada 
for constituída de um material de média ou alta resistência mecânica.

A UEE abrange um vasto campo de aplicabilidade industrial na usinagem de metais. Entretanto, a preços com petitivos, a UEE é utilizada na fabricação de ferramentas, matrizes para forjamento e estampagem, moldes, matri zes de corte e micro-usinagens em equipamentos de motores, instrumentos científicos etc.

\subsubsection{Retificação por Eletroerosão - REE}

A retificação por eletroerosão (REE) é um método de remoção de metal por meio de descargas elétricas a alta frequência entre uma ferramenta giratória e uma peça a ser usinada, as quais são separadas entre si e banhadas por um fluido dielétrico - normalmente óleo hidrocarboneto filtrado -. A Figura 26 mostra esquematicamente o processo.

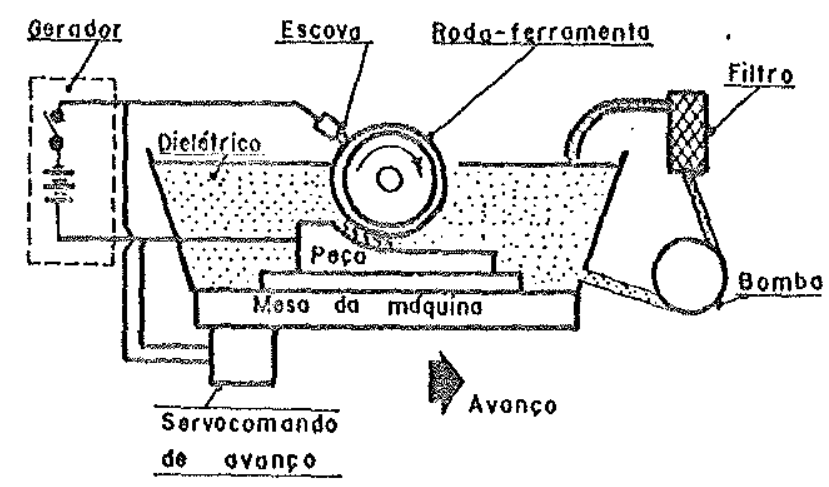

$\begin{aligned} \text { Fig. } 26 \text { - } & \text { Componentes básicos de uma retifica- } \\ \text { dora eletroerosiva } & \end{aligned}$

Nas mäquina REE, o "gap" é servocomandado, com um ajuste normalmente compreendido entre 8 e $12 \mu m$; os ge radores utilizados cobrem uma faixa de 30 a $1.00 \mathrm{~V}, 0,5$ a 200 A e 2 a $500 \mathrm{kHz}$. O elétrodo-ferramenta giratório, nor 
malmente de grafite, tem uma velocidade tangencial varian do em una faixa de 0,5 a $3,0 \mathrm{~m} / \mathrm{s}$.

Máquinas de retificação por eletroerosão ainda não são fabricadas no Brasil, mas são disponíveis nos par ques industriais dos Estados Unidos, Rüssia, Hungria, Sur ça, dentre outros. Uma fresadora horizontal ou uma retífi ca plana convencional pode ser adaptada para o processo, desde que se acople à mesa da máquina um reservatório apropriado para encerrar o líquido dielétrico, bem como um gerador conveniente. O método também é possível ser execu tado em u'a máquina UEE, após se montar a roda-ferramenta no eixo vertical do cabeçote e transferir o sistema de servoavanço deste para a mesa da máquina.

Pode-se obter, com a REE, maior precisão na retificação de materiais duros, tais como ferramentas conformadoras ou carbonetos metälicos engastados em barras, muito embora sua velocidade de remoção de material seja baixa. Com rodas-fexramenta acuradas, a REE assegura tole râncias de até $2,5 \mu \mathrm{m}$, sendo comum se obter $\pm 5 \mu \mathrm{m}$; acaba mento superficial da ordem de $0,2 \mu \mathrm{m}$ RMS é o melhor que se consegue ao se utilizar rodas de grafite. Ferramenta de latão também é indicada ao processo, principalmente na usinagem de peças de seções delgadas; no entanto, além de ser mais difícil usinä-la com acuracidade elevada, é mais dispendiosa que a de grafite.

A REE, afora as aplicações citadas, é indicada na retificação de metais quebradiços e formas frágeis, de vido à ausência de forças de corte significativas no processo.

\subsubsection{Serramento por Eletroerosão - SEE}

O serramento por eletroerosão (SEE) é uma varia ção da UEE que combina o movimento da serra de fita com a erosão elétrica da peça, como indica a Figura 27 . Movendo -se rapidamente $(25$ a $30 \mathrm{~m} / \mathrm{s})$ a aresta de corte da fita 
de aço especial com espessura nominal de $0,635 \mathrm{~mm}$ é guiada na peça por insertos de carbonetos metálicos. Um corte de $0,794 \mathrm{~mm}$ é realizado no material usinado e, diferentemente da UEE, o "gap" não é controlado, nem se utiliza um dielëtrico fluídico no processo, mas um fluxo de água res fría a peça, não evitando a contínua formação de arco elé trico, sob condições de alta amperagem e baixa voltagem $\left(\begin{array}{llll}6 & \text { a } & 24 & \mathrm{~V}\end{array}\right)$.

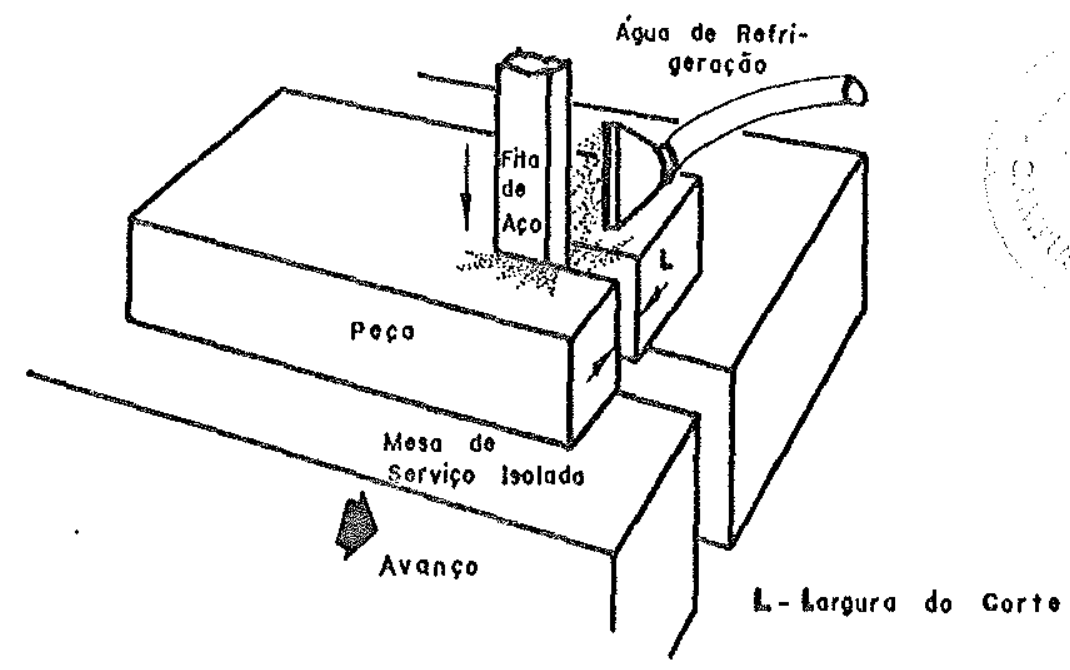

Fig. 27 - Esquema de funcionamento de u'a máquina de serrar por eletroerosão 10

Como nos demais processos eletroerosivos, nem a ferramenta nem a peça são sujeitas a maiores esforços de corte. Durante a usinagem, é necessário fazer-se uma ajus tagem precisa entre a velocidade de avanço da mesa de tra balho e a velocidade de erosão do arco elétrico, evitando assim o contato físico entre ferramenta e peça, descaracterizando e prejudicando o processo.

Estruturas celulares frágejs podem ser cortadas pela SEE, sejam elas de alumínio, aço inoxidável, titânio etc. Outro campo de utilização vantajosa da SEE é o corte de tubulações de trocadores de calor de paredes finas, bem como peças similares. O processo não deixa rebarba, nem tampouco produz achatamento das bordas da peça usinada. 


\subsubsection{Corte com Fio por Eletroerosão - CFEE}

o corte com fio por eletroerosão (CFEE) é uma forma especial de usinagem por eletroexosão na qual o elé trodo-ferramenta é um fio condutor que se move continuamente. O fio tensionado de cobre, latão, tungstênio ou mo libdênio, tem pequeno diâmetro, da ordem de 50 a $300 \mu \mathrm{m}$, ou menor, e é guiado para produzir um corte estreito e re to. Geralmente, um movimento programado, ou numericamente comandado, guia o corte, enquanto a sua largura é ditada pelo controle de energia de descarga. A figura 28 apresen ta o processo bãsico de corte com fio por eletroerosão, nu mericamente comandado.

As duas maiores limitações do CFEE dizem respei to ao fato do processo não executar cavidades cegas e ao custo do equipamento, avaliados entre cem e trezentos mil dólares, dependendo do tamanho, versatilidade, acuracidade e sofisticação do sistema. Em contra-partida, enquanto na UEE elétrodos complexos representam cerca de 40 a $60 \%$ do preço total da peça usinada, os custos relacionados com o fio de corte, no CFEE, utilizado uma única vez, são bai xos .

A velocidade de corte do processo é muito bai$\mathrm{xa}$, também. Na usinagem de carbonetos de $25 \mathrm{~mm}$ de espessu ra obtém-se uma velocidade de, apenas, $15 \mathrm{~mm} / \mathrm{hora}$; peças de aço temperado são cortadas a uma velocidade duas vezes maior que essa, para igual espessura. Trabalhando-se a es sa "rapidez", consegue-se um acabamento superficial de cerca de $40 \mu \mathrm{m}$ RMS, muito rugoso, portanto. Um acabamento refinado sacrifica a velocidade de corte, sendo a recípro ca, verdadeira.

Há dois tipos básicos de máquinas CFEE: o primeiro, mais antigo, apresenta o sistema-guia do fio, esta cionário, enquanto a peça se move; na outra configuração, há uma inversão no movimento relativo entre a peça usinada e o ststema-guia da ferramenta. Enquanto no primeiro tí 


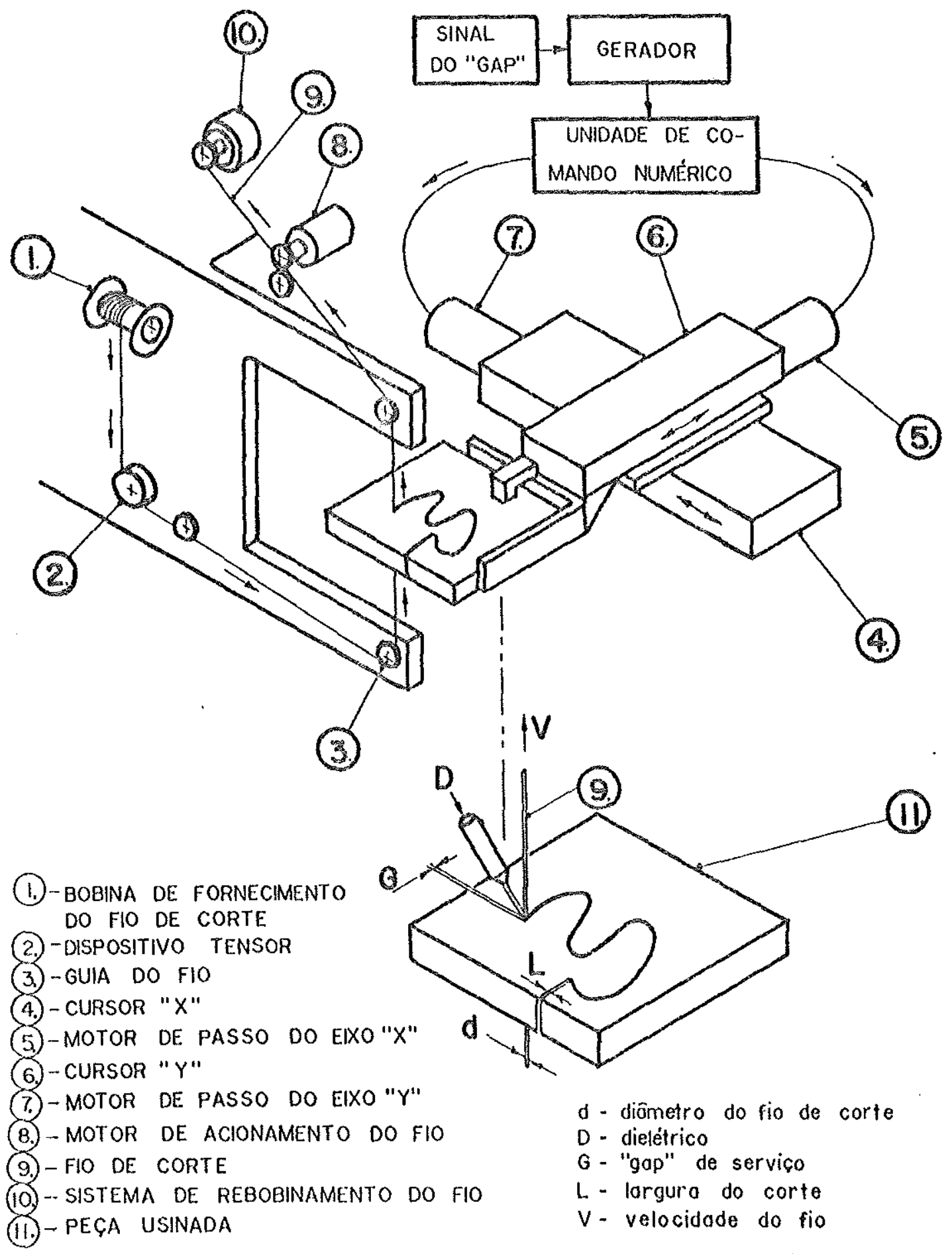

Fig. 28 - Sistema de corte com fio por eletroerosão que utiliza comando numérico ${ }^{10}$

po o sistema-guia do fio é mais robusto e fornece uma melhor acuracidade, no segundo, há uma compensão relaciona- 
da à massa da peça, cuja seção transversal seja variável, além desse sistema simplificar o carregamento e descarregamento do material na mesa de serviço.

o dielétrico utilizado no processo é água filtrada e desionizada e, em menor escala, óleo hidrocarbone to. A peça pode ser usinada totalmente submersa nesse líquido, como na UEE, ou apenas sob um banho de um a três jatos dielétricos concentrados na zona de corte.

A utilização do CFEE permite a usinagem de formas complexas, quais sejam, engrenagens, polias, catracas, gabaritos, lapidação de monocristais, cantos quadrados internos etc., em materiais condutores de eletricidade. Matrizes para conformação mecânica e execução de perfis complexos são também aplicações correntes do CFEE. 
4. MĀQUINAS, FERRAMENTAS E ASPECTOS ECONOMTCOS DA USINAGEM DE METATS POR ELETROEROSÃO

\subsection{Generalidades}

Uma vez discutidos os fundamentos da UEE, anali. sam-se, neste capítulo, os equipamentos e as ferramentas utilizadas nesse processo. Devido às características inerentes à UEE, cujos fundamentos diferem completamente daqueles pertinentes à usinagem convencional, as máquinas e as ferramentas empregadas no processo eletroerosivo, distinguem--se daquelas usadas tradicionalmente na usinagem de materiais, como será visto a seguir.

o capítulo é complementado por uma análise comparativa dos custos de fabricação de uma matriz para forjamento, executada por fresanento por copiamento e por UEE. Este método mostra-se competitivo e, em algumas aplicações nesse campo, é absolutamente imprescindível às mode $\underline{x}$ nas ferramentarias. 


\subsection{Máquinas UEE}

A usinagem por eletroerosão, mais que um proces so de usinagem, é uma técnica na qual a forma trabalhada é reproduzida pelo perfil da ferramenta. A partir do momento em que essa reprodução é fiel, o interesse pelo pro cesso aumenta, pois ele oferece a possibilidade de executar impressões ou furações de quaisquer formas em todos os materiais condutores de eletricidade.

A "fidelidade de reprodução" será tanto melhor à medida que o posicionamento, a orientação e a trajetó ria do elétrodo-ferramenta, em relação à peça, forem perfeitamente determinados. Tais necessidades exigem u'a mäquina que, além de um posicionamento preciso, possa assegurar, no tempo, a perpendicularidade, a linearidade e a estabilidade do eixo de deslocamento da ferramenta.

Na máquina, esses imperativos geométricos exprí mem-se pela necessidade de se tex u'a máquina rígida, estável, com guias precisas e um sistema de restriamento do dielétrico que minimize o surgimento de deformações térmi cas, condições básicas para a obtenção dos resultados almejados.

Sendo numerosas as aplicações da usinagem por $e$ letroerosão em nossos dias, é 1ógico que deve haver um ca samento entre a reprodução fiel, o posicionamento preciso e o emprego econômico do processo, na prática. Isso acarretou o surgimento de três famíli as de máquinas-ferramenta eletroerosivas, a saber:

- pequenas máquinas para operações de superacabamento e alta precisão: destinam-se à indústria eletrônica, laboratórios de pesquisa (na separação de monocristais, por exemplo), tecnologia de reatores atômicos e outras aplicações que envolvem problemas de produção. 
- máquinas universais médias: têm largo emprego na fabricação geral de ferramentas e moldes, bem como na execução de furos afilados de extrema precisão.

- grandes máquinas e máquinas especiais: são utilizadas na fabricação de matrizes e moldes de grandes dimensões, ferramentas para carrocerias na indústria automobilística etc.

Em todos os tipos de máquinas de usinagem por e letroerosão comercializados, distinguem-se três conjuntos principais :

4.2.1 - um mecânico, composto de uma base e sua respectiva coluna, um cabeçote de usina gem, uma mesa de serviço e um sistema de fixação para a peça e para o elétrodo-ferramenta.

4.2.2 - um elétrico, composto de um gerador ele troerosivo, um sistema regulador do avanço do cabeçote (normalmente híbriço), um termo-resistor para monitoração da temperatura do dielétrico e demais meca nismos e órgãos elétricos componentes dos diversos tipos de máqui nas-ferramen ta eletroerosivas.

4.2.3 - um hiđráulico, composto pelo sistema de bombeamento e filtragem do fluido dielé trico, um reservatório de usinagem e to do o circuito que assegura a circulação do líquido de serviço. Em grande parte das máquinas de usinagem por eletroerosão, notadamente naquelas construídas nos últimos quinze anos, há outros órgãos hidráulicos, tais como o comando e o mecanismo de avanço do elétrodo-ferra 
menta (nas primeiras máquinas, este sis tema era eletromecânico; hoje, passou a ser eletro-hidráulico).

\subsubsection{Conjunto Mecâni.co}

Para assegurar uma boa usinagem, o conjunto mecânico de u'a máquina UEE deve possuir boa rigidez e seus elementos móveis devem ter movimentos bastante precisos.

Devido às características diferentes de traba1ho, a estrutura das máquinas-ferramenta eletroerosivas tem uma construção mais leve que a das máquinas-ferramenta tradicionais.

A base da máquina, geralmente fundida ou soldada, comporta uma coluna que, por sua vez, suporta um cabeçote porta-elétrodo, mostrados na Figura 29. A coluna tam bém é fundida ou soldada e deve ser bem dimensionada e nervurada, pois os esforços desenvolvidos pelo gás e pelo calor durante a usinagem não são desprezíveis, principalmente para niveis de corrente superiores a $100 \mathrm{~A}$. Não há de se esquecer que a sua deformação, em função da tempera tura, deve ser muito pequena.

A mesa de serviço, montada sobre a base, pode se deslocar horizontalmente segundo os dois eixos de coordenadas retangulares, facilitando assim o posicionamento preciso da peça em relação ao elétrodo.

o cabeçote porta-elétrodo deve possuir precisão de movimento elevada, porque é ele quem assegura o deslocamento do elétrodo em relação à peça. Esse movimento ver tical é servocomandado, baseando-se o sinal de referência do sistema de controle na diferença de potencial entre a peça e o elétrodo. Há cabeçotes de acionamento eletromecâa nico e eletro-hidráulico, além dos manuais, nas máquinas surgidas e comercializadas durante as ủltimas três décadas. 


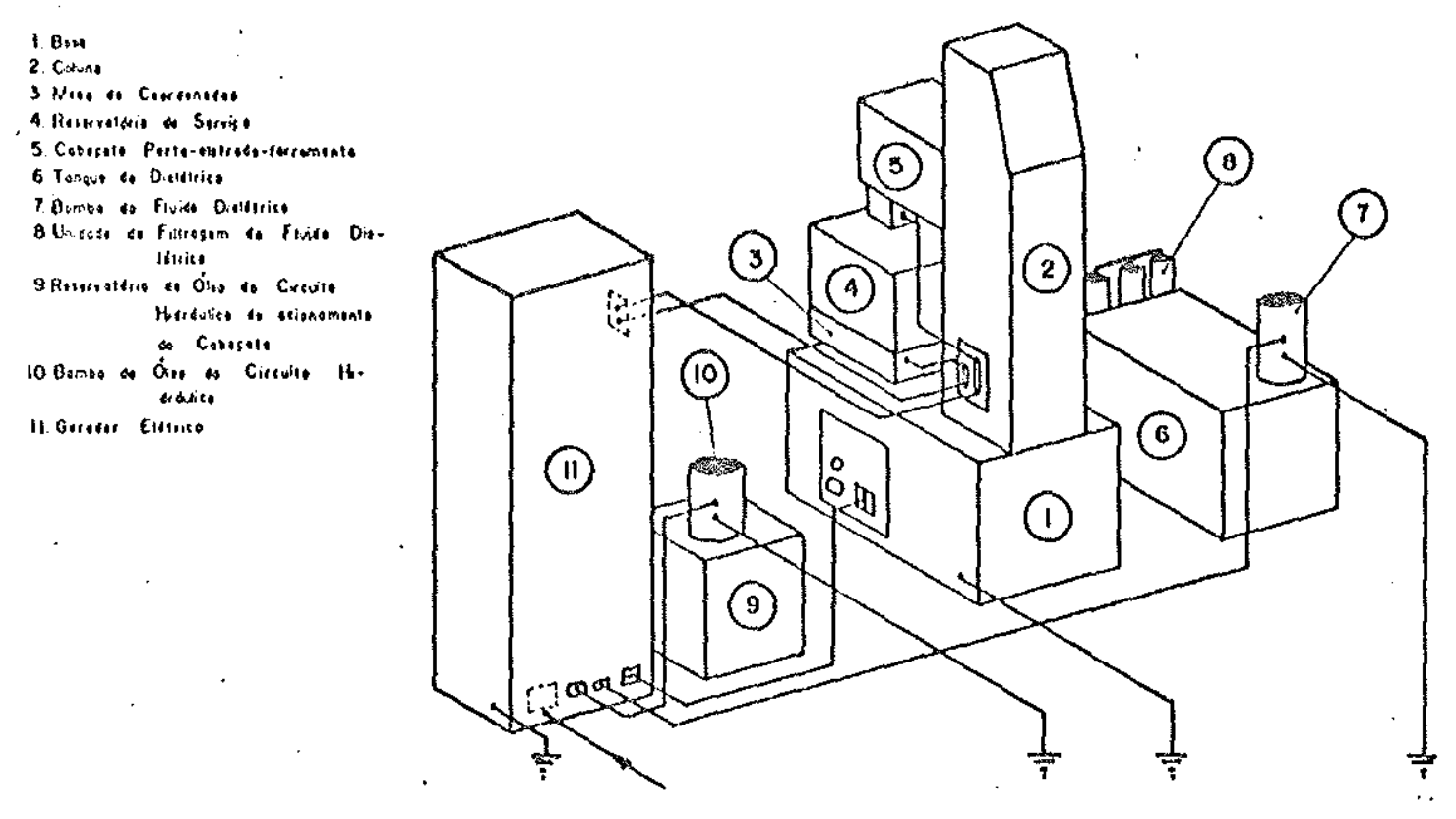

Fig. 29 - Equipamento utilizado no processo de usinagem por eletroerosão

\subsubsection{Conjunto Elétrico}

o elemento-chave do conjunto elétrico de u'a má quina UEE é o gerador elétrico. Ele é, por assim dizer, o "coração" do processo eletroerosivo, responsável que é pelo fornecimento de energia à máquina-ferramenta.

A Figura 30 apresenta vários tipos básicos de circuitos elétricos utilizados pelos fabricantes de máquí nas UEE para fornecer pulsos de corrente contínua às máquinas eletroerosivas. Nenhum tipo particular, no entanto, é adequado a todas as condições de usinagem.

Os diversos circuitos apresentados representam, na ordem cronológica em que foram sendo utilizados, as principais etapas no desenvolvimento do projeto de gerado res elëtricos.

A maioria das máquinas pioneiras utilizava versões sofisticadas do circuito da Figura 30-a. Conhecido tecnicamente como um"circuito $\mathrm{RC} "$, ele também é chamado 

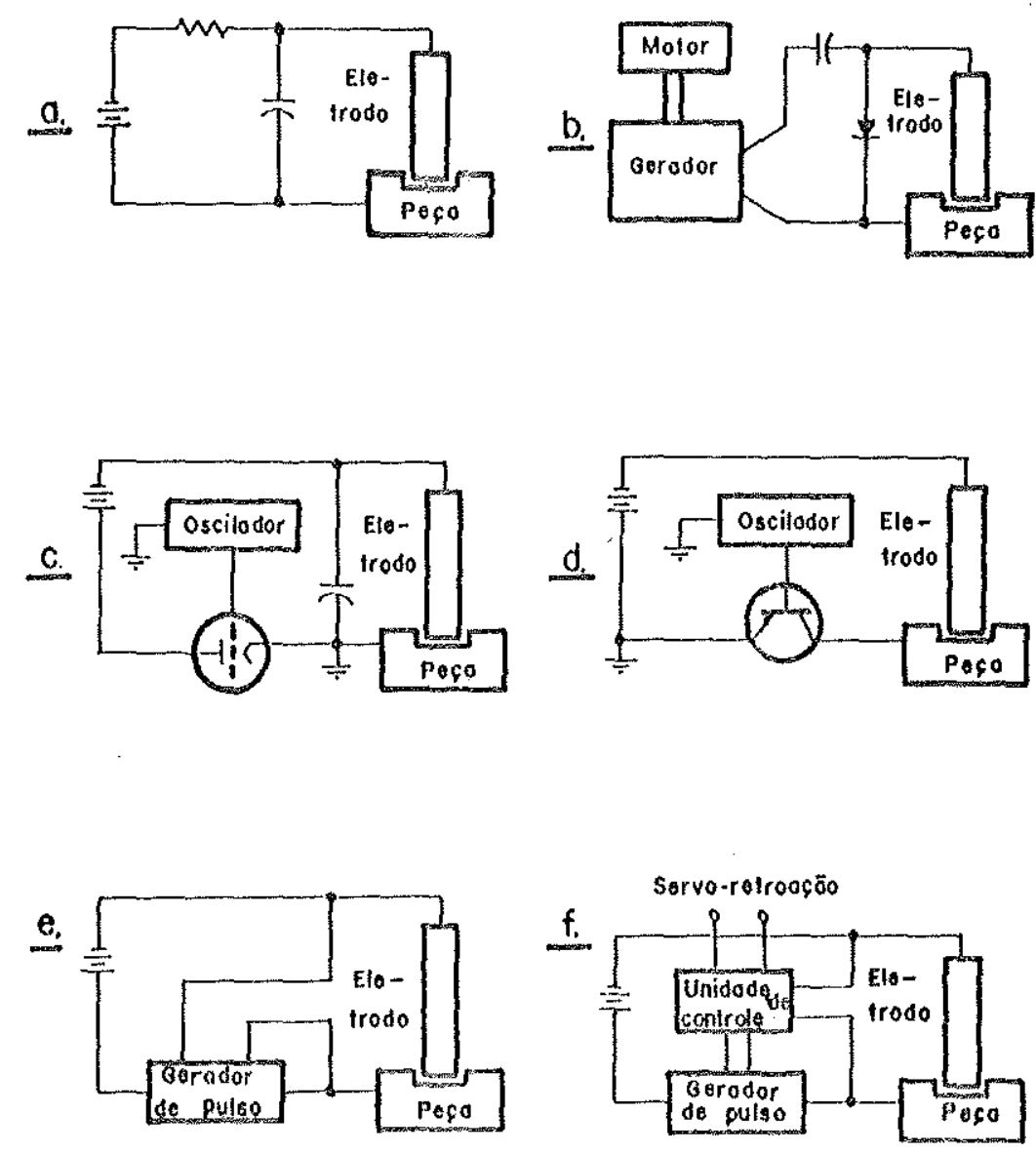

Fig. 30 - Seis tipos básicos de geradores elétricos para UEE ${ }^{11}$

de "circuito Lazarenko" e "circuito de relaxação", pois e le armazena uma carga por um período de tempo e então se "relaxa", ao descarregá-la através de uma resistência. Nes te caso, a carga é armazenada por um capacitor e liberada através da baixa resistência do "gap" de descarga ionizado.

o elétrodo-ferramenta e a peça formam, na verda de, um outro capacitor, conectado em paralelo com o capacitor do circuito, que é escolhido de modo que a capacitância elétrodo-peça possibilite a descarga através do "gap". Essa capacitância do "gap" varia de 0,01 a $100 \mu \mathrm{F}$, durante o uso normal. 
o valor da resistência, que determina a velocidade de carregamento do capacitor, e a capacitância em pa ralelo, devido ao "gap", determinam a frequência de descargas do circuito de relaxação que, apesar de simples e ro busto, é extremamente limitado na sua capacidade de remoção de metal. O circuito $\mathrm{RC}$ presta-se muito bem para operações de acabamento.

O circuito básico apresentado na Figura 30-b é o de um gerador rotativo de impulsos. Concebido para proporcionar maiores velocidades de remoção de metal que os circuitos de relaxação, este circuito permite que um gera dor de corrente contínua de alta frequência, padrão, seja usado para produzir pulsos unidirecionais.

No gerador rotativo, o capacitor é carregado através de um díodo, em meio ciclo; no meio ciclo seguinte, a soma da tensão elétrica do gerador com a do capacitor carregado é aplicada ao "gap", através de pulsos longos e, consequentemente, à baixa frequência de operação, não-ajustável. Isso permite uma remoção de metal a veloci dades bastante elevadas e um acabamento superficial extre mamente rugoso.

Introduziram-se, então, os geradores valvulados - Figura 30-c - consistindo na substituição do resistor do circuito básico de relaxação mostrado na Figura 30-a por um conjunto de válvulas conectadas em paralelo (mostrada esquematicamente como uma única, na Figura 30.c).Con venientemente controlado, o banco de válvulas torna-se, com efeito, um resistor variáve1, funcionando no circuito como o dispositivo interruptor, responsável pela frequência de descarga no "gap" e pela magnitude energética de cada descarga. Isso é assegurado pelo oscilador de frequência fixa, através da interrupção periódica da corrente do "gap".

Há uma grave restrição para esse tipo de circui to, contudo, as características elétricas das vālvulas (alta tensão, baixa amperagem) não são diretamente compa- 
tíveis com as condições elétricas exigidas pelo "gap" em regime de desbaste (alta amperagem e tensão relativamente baixa). A Figura 30-d ilustra esquematicamente o uso de transístores substituindo as válvulas. Neste circuito, o interruptor é acionado por um oscilador de frequência ajustável. e não requer o uso de capacitores em paralelo com o "gap".

Tais geradores deram um novo alento ao processo eletroerosivo, uma vez que os transístores permitem altas amperagens e baixas voltagens e funciona como um eficien te dispositivo interruptor. Nos circuitos transistoriza-dos, o sinal do oscilador controla não apenas o fim do pulso, mas também o tempo durante o qual o pulso é libera do entre o elétrodo e a peça, permitindo que o pulso ge ra do seja totalmente controlado.

Entretanto, o tempo de ionização do "gap" varia de descarga para descarga, exigindo um circuito com retro ação, Figura.30-e. Esse circuito mantém o tempo de duração do pulso e a corrente de pico, adequando, contudo, a frequência de descarga, com as variações do tempo de ioni zação do "gap".

A Figura 30-f apresenta a mais nova concepção de geradores elétricos empregados no processo de usinagem por eletroerosão. Um dos parâmetros monitorados é o avanço do elétrodo, diferentemente dos outros geradores. A in teração entre o gerador e o servomecanismo de avanço do e létrodo é feita por meio de controle adaptativo.

o "gerador ideal", capaz de controlar todas as variáveis que afetam o processo de corte, está longe, ainda, de ser desenvolvido. Afinal de contas, corte consistente, velocidade de remoção de metal elevada, acabamento superficial refinado, e baixo desyaste do elétrodo, parecem se contrapor. E, embora um gerador possa ser ajustado para fornecer um compromisso satisfatório para uma combi nação particular elétrodo/peça, dificilmente a sua eficiência serā a mesma para todas as combinações imaginá- 
veis de materiais metálicos, sejam os seus elementos eletrônicos ativos, válvulas, transístores ou circuitos inte grados digitais.

Isso só será exequível quando o conhecimento e - controle dos parâmetros de corte para quaisquer combina ções de materiais possibilitarem a formulação de relações quantitativas bem definidas e eficientes.

\subsubsection{Conjunto Hidráulico}

A maioria das máquinas UEE mais recentes possui duas unidades distintas de circulação fluídica: o circuito hidráulico que alimenta o servo-sistema de acionamento do cabeçote eletroerosivo e o circuito hidráulico do sistema dielétrico, mostrados esquematicamente na Figura 29.

O servo-sistema de acionamento do cabeçote porta-ferramenta é geralmente constituído por um cilindro hi dráulico operado por uma válvula eletro-hidráulica. suas características dinâmicas asseguram uma boa resposta do sistema aos sinais de perturbação provenientes da variação no espaçamento elétrodo-ferramenta/peça e consequentes flutuações na tensão no "gap".

As máquinas-ferramenta eletroerosivas incluem também um sistema dielétrico para enchimento do reservató rio de serviço em que a peça a ser usinada é imersa. Há dois métodos básicos de enchimento desse reservatório de serviço: aplicação de ar sob pressão ao fluido contido no tanque de dielétrico, ou bombeamento do fluido dielétrico desde esse tanque até o reservatório de serviço por meio de bomba centrífuga. Em ambos os métodos, atingindo o nível desejado de dielétrico no rescrvatório de serviço, o fluido retorna, por gravidade, para o tanque de dielétrico e é aí resfriado e decantado. O sistema de resfriamento é constituído por alguns tubos aletados, por onde circula água da própria instalação fabril. 
o circuito hidráulico de dielétrico é complemen tado por um sistena que inclui unidades de lavagem do "gap" por injeção ou sucção do fluido dielétrico, e por unidade de filtragem do dielétrico, de cuja eficiência de pende multo a qualidace do acabamento da superfície usina da. Sob condições severas de desbaste, utilizam-se as mäquinas mais modernas de uma unidade de filtragem de farinha diatomácea, que tem capacidade de remover grande quan tidade de cavacos do fluido dielétrico sem os problemas de manutenção que envolvem os filtros de cartucho normalmente utilizados.

\subsection{Ferramentas UEE}

As brocas, na furação; as serxas, no serramento; as fresas, no fresamento; as ferramentas de barras, no torneamento, são substituídas, na usinagem por eletroerosão, por um elétrodo-ferramenta cuja seção frontal tem o mesmo contorno da superfície a ser usinada.

Se, por um lado, a fabricação dessa ferramenta é mais demorada e mais cara que a da ferramenta convencio nal, por outro, assegura a reprodução fiel da gravura des sa ferramenta na peça usinada. Ela pode ser utilizada por diversas vezes, dependendo da deterioxação da forma pro vocada pelo desgaste em serviço e da precisão geométrica exigida para a peça usinada.

A seleção do material e do processo de fabricaÇão do elëtrodo-ferramenta ë uma tarefa decisiva não somente sob o ponto de vista tecnológico, como também econô mico. Em algumas aplicações, o custo do elétrodo pode re-presentar mais que a metade do custo total da peça usinada por UEE.

Todos os materiais condutores de eletricidade podem se prestar à fabricação da ferramenta eletroerosiva. Teoricamente, os materiais que possuem os mais elevados 
pontos de fusão e sublimação e as menores resistividades elétricas constituir-se-ão nas melhores ferramentas.

os materiajs consagrados pela prática na confec 'ção de elétrodos são os seguintes:

- 4.3.1-Cobre eletrolítico

-4.3 .2 - Grafite

- 4.3.3 - Cobre ao telúrio, ao cromo, ou ao chum bo

- 4.3.4 - Cobre ao tungstênio

- 4.3.5 - Tungstênio à prata

- 4.3.6 - Liga de alumínio (Silumin)

- 4.3 .7 - Latão

- 4.3.8 - Tungstênio. Molibdênio

$-4.3 .9-$ Aço.

\subsubsection{Cobre Eletrolítico}

E largamente utilizado em UEE. De bai xo custo, pode ser fabricado por deformação a frio ou a quente; por extrusão; por trefilação; por estiramento; por galvanoplastia e pelos métodos tradicionais de usinagem.

As propriedades físicas desse material, mais im portantes à UEE, são as seguintes:

- massa específica: $8,9 \mathrm{Kg} / \mathrm{dm}^{3}$ (a $20^{\circ} \mathrm{C}$ )

- ponto de fusão: $1.083{ }^{\circ} \mathrm{C}$

- resistividade elétrica: $0,017 \mu \Omega \mathrm{m}\left(\mathrm{a} 20^{\circ} \mathrm{C}\right.$ ).

o cobre retificado produz um acabamento superficial extremamente preciso na peça usinada; o desgaste da ferramenta fabricada com esse material é maior que aquele obtido com grafite.

Em máquinas UEE com geradores de relaxação, o cobre eletrolitico apresenta um desempenho de usinagem ex 
celente; em geradores de pulso controlado, contudo, seu desempenho cai um pouco.

\subsubsection{Grafite}

Muito utilizado em UEE. De baixo custo, a ferra menta de grafite é fabricada pelos processos convencionais de usinagem.

A anisotropia do grafite exerce uma influência muito grande sobre as suas propriedades elétricas e térmi cas, que variam sensivelmente segundo as diversas direções predeterminadas.

Suas propriedades físicas mais significativas à UEE são as seguintes:

- massa específica: 1,6 a $1,85 \mathrm{Kg} / \mathrm{dm}^{3}$ (a $20{ }^{\circ} \mathrm{C}$ )

- temperatura de sublimação: $3.600{ }^{\circ} \mathrm{C}$

- resistividade elétrica: 8 a $15 \mu \Omega m\left(a 20{ }^{\circ} \mathrm{C}\right.$ ).

o tamanho do grão de grafite é decisivo à obten ção de uma boa qualidade superficial da peça usinada Grãos finos asseguram um ótimo acabamento, enquanto grãos maiores propiciam una rugosidade superficlal de baixa qualida de.

O grafite presta-se melhor à usinagem com equipamento que utiliza gerador de pulso controlado do que com aquele do tipo relaxação.

A ferramenta de grafite é praticamente insensível aos choques térmicos e sua deformação é desprezível. Entretanto, as partículas desprendidas da ferramenta, devido ao seu desgaste, têm características abrasivas e podem danificar as guias da máquina-ferramenta eletroerosiva. 
4.3.3. Cobre ao Telürio, ao Cromo ou ao chumbo

A adição de 1 a $3 \%$ de telúrio, cromo ou chumbo, no cobre eletrolítico, melhora a usinabilidade do cobre, na fase de fabricação do elétrodo.

Essa prática é comum apenas em ferramentas de geometrias complexas. O desempenho da UEE, com esses elétrodos, é pior do que o obtido com ferramentas de cobre eletrolítico: o desgaste dos elétrodos é 15 a 25\% maior e a velocidade de remoção de material é cerca de $10 \%$ menor.

\subsubsection{Cobre-Tungstênio}

o cobre-tungstênio é um composto de pós de tungs tênio (50 a $80 \%)$ e de pós de cobre $(50$ a $20 \%)$. $\bar{A}$ medida que se aumenta oteor de tungstênio no composto, é dificultada a fabricação da ferramenta, melhora o seu desgaste em ope ração eletroe rosiva e descresce a velocidade de remoção de material.

Os principais parâmetros físicos desse composto são os seguintes:

- massa específica: 15 a $18 \mathrm{Kg} / \mathrm{dm}^{3}$ (a $20{ }^{\circ} \mathrm{C}$ )

- resistividade elétrica: 0,045 a $0,055 \mu \Omega \mathrm{m}$ (a $\left.20^{\circ} \mathrm{C}\right)$.

o custo do cobre-tungstênio é maior que o dos materiais citados anteriormente. Ele tem um excelente desempenho em qualquer gerador eletroerosivo e é particular mente indicado na fabricação de ferramentas que possuem detalhes finos.

\subsubsection{Tungstênio à Prata}

Apresenta características um pouco melhores que o cobre tungstênio. Devido ao seu elevado custo, torna-se praticamente proßbitiva a sua utilização em operações ordi 
nárias de eletroerosão. Para cortes rasos, o elétrodo de tungstênio à prata dispensa um sistema auxiliar de lavagem.

Suas propriedades físicas relevantes à UEE, são as seguintes:

- massa específica: 12, 1 a $17,0 \mathrm{~kg} / \mathrm{dm}^{3}$ (a $20^{\circ} \mathrm{C}$ )

- resistividade elétrica: 0,021 a $0,041 \mu \Omega \mathrm{m}$ (a $\left.20{ }^{\circ} \mathrm{C}\right)$.

4.3.6. Liga de Alumínio (Silumin)

A composição nominal dessa liga é a seguinte: 85\% Al, $11 \% \mathrm{Si}, 0,4$ a $0,6 \% \mathrm{Mg}, 1 \% \mathrm{Zn}, 1 \% \mathrm{Mn}, \mathrm{Fe}, \mathrm{Cu}$.

Essa liga tem um custo relativamente baixo e é utilizada na fabricação de ferramentas destinadas à usina gem de aço e metais nobres, cujas cavidades são de grandes dimensões (superiores a $50 \mathrm{~cm}^{2}$ ). Seu desempenho com circuito RC deixa muito a desejar.

o silumin é facilmente usinävel pelos métodos convencionais; ferramentas de silumin podem ser fundidas sem maiores problemas.

Utilizando-se ferramenta desse material, o valor da corrente de descarga pode alcançar até $270 \mathrm{~A}$, permitindo uma velocidade de remoção de material de cerca de $290 \mathrm{~mm}^{3} / \mathrm{mín}$; o desgaste da ferramenta é maior do que o ob tido com o cobre eletrolítico.

\section{3 .7 - Latão}

Apesar de poder ser empregado na usinagem por e letroerosão de quase todos os metais, ser disponível comercialmente sob diversas formas e ter um custo muito acessível, a ferramenta UEE de latão apresenta um desgaste muito elevado.

Com geradores de relaxação, seu desempenho é 
muito ruim, melhorando com a utilização de geradores de pulso controlado.

\subsubsection{Tungstênio. Molibdênio}

São indicados na usinagem de mi cro-orifícios, devido ao pequeno desgaste da ferramenta.

Encontram-se no mercado sob a forma de fios, barras e tubos. Os elétrodos de tungstênio têm um desempe nho mui.to bom junto aos geradores de relaxação. Esse desempenho cai um pouco quando se utiliza um gerador de pul so controlado.

As principais propriedades físicas do tungstênio (W) e molibdênio (Mo) são as seguintes:

- massa específica: 19,3 $\mathrm{kg} / \mathrm{dm}^{3}$ (W) e 10,2 (Mo) (a $20{ }^{\circ} \mathrm{C}$ )

- temperatura de fusão: $3.380{ }^{\circ} \mathrm{C}$ (W)e $2.620{ }^{\circ} \mathrm{C}$ (Mo)

- resistividade elétrica: 0,055 $\mu \Omega \mathrm{m}$ (W) e 0,057 $\mu \Omega \mathrm{m}$ (Mo) (a $\left.20{ }^{\circ} \mathrm{C}\right)$.

\section{3 .9 . Aço}

Apesar de ser facilmente fabricada, a ferramenta eletroerosiva de aço proporciona uma usinagem muito mais lenta que aquelas obtidas com ferramentas de cobre ou grafite; o desgaste é satisfatóxio apenas quando se usinam peças de determinados tipos de aço. 
4.4. Aspectos Econômicos da Fabricação de u'a Matriz pa ra Forjamento por UEE e Fresamento por Copiamento

\subsubsection{Generalidades}

A fabricação de matrizes para processos de conformação pode ser realizada, na atualidade, por quatro pro cessos básicos: fresamento por copiamento, usinagem por eletroerosão, usinagem por comando numérico (CN) e comando numérico assistido por computador (CNC).

A necessidade de $s \in$ fabricarem matrizes de boa qualidade a preços competitivos exige para cada aplicação uma análise criteriosa dos processos mais indicados a essa aplicação. Geralmente há um processo ótimo para a usinagem de uma peça ou de um lote de $\mathrm{N}$ peças.

os fatores mais importantes a serem levados em conta na seleção do processo de fabricação são a geometria da cavidade da matriz a ser usinada, o material que a cons titui, o tamanho dessa matriz e as potencialidades e limitações dos equipamentos disponíveis na ferramentaria que e xecutará o serviço de usinagern.

No fresamento por copiamento, deve-se desenvolver um modelo completamente detalhado da configuração a ser usinada e fazer a traçagem da forma da cavidade.

Na UEE, há necessidade de se fabricarem um ou mais elétrodos que reproduzam a cavidade da peça a ser usi nada.

Na usinagem por comando numérico (CN) ou comando numérico assistido por computador (CNC), a configuração a ser usinada deve ser inteiramente programada e introduzida na unidade de comando. No Brasil, as mäquinas $C_{N}$ e CNC são ainda escassas ou simplesmente inexistem nas ferramentarias. A fabricação de matrizes resume-se, pois, ao fresamento por copiamento e usinagem por eletroerosão. Respaldado pelo trabalho de Rodrigues et alii'², 
far-se-á uma análise comparativa dos custos de fabricação de uma matriz para forjamento fabricada por fresamento por copiamento e UEE.

A Tabela 4.1 mostra a sequência normal de operações da fabricação de uma matriz para forjamento. Em ambos os processos, fresamento por copiamento e UEE, utilizaram- se seis etapas principais na execução de uma matriz para forjamento de um garfo de engate empregado em uma caixa de velocidades para veículos de carga.

\subsubsection{Descrição da Matriz Usinada}

Os blocos de cada matriz, de aço temperado, mediam $381 \times 407 \times 305 \mathrm{~mm}$. O projeto da matriz previa três cavidades, a saber:

- uma "estação roladora", na qual o material bruto do garfo sofre uma conformação inicial para adequar a sua distribuição de volume à estação seguinte;

- uma gravura de pré-forma, em que a geometría da peça obtida é uma configuração grotesca do garfo de engate, com acentuada presença de rebarba;

- uma gravura final ou de acabamento, na qual a peça acabada é obtida com as tolerâncias especí ficadas no projeto.

Essa matriz é utilizada em um martelo eletro-hidráulico de 2.500 lbf $(11.000 \mathrm{~N})$; as configurações das duas partes são idênticas.

\subsubsection{Anälise dos Tempos de Fabricação da Matriz}

A Tabela 4.2 indica os tempos globais das operações para ambos os processos; considerando-se que a "estação roladora" pode ser feita economicamente por usinagem 


\begin{tabular}{|c|c|c|c|c|c|c|}
\hline OP & & \multicolumn{2}{|c|}{ FRESAMENIO POR COPTAMENTO } & \multicolumn{2}{|c|}{ USINAGEM POR ELETROEROSÃO } & \multirow{9}{*}{ 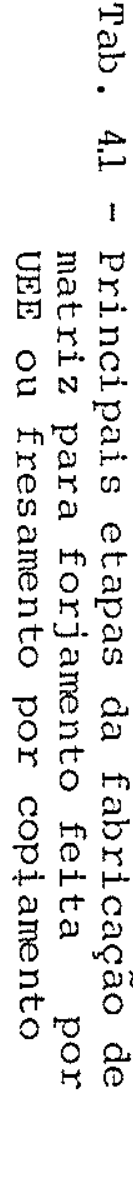 } \\
\hline$n \%$ & Operação & $\begin{array}{c}\text { Meio para realização } \\
\text { da operação }\end{array}$ & Descriçäo & $\begin{array}{l}\text { Neio para realização } \\
\text { da cperação }\end{array}$ & Descrição & \\
\hline 1 & Traçagen & Bancada & $\begin{array}{l}\text { Iocalização dos pontos principais } \\
\text { para guia da fresa-copiadora }\end{array}$ & Bancada & $\begin{array}{c}\text { Deteminação das referéncias para } \\
\text { posicionamento do elétrodo e do } \\
\text { bloco }\end{array}$ & \\
\hline 2 & Montagen & Eresa copiadora & $\begin{array}{c}\text { Posicionamento da peça na resa. A } \\
\text { juste das condiçöes de usinagem } \\
\text { da mäquina }\end{array}$ & $\begin{array}{c}\text { Máquina de eletroero } \\
\text { são }\end{array}$ & $\begin{array}{c}\text { Posicionamento da peça na mesa. A } \\
\text { juste das condiçoses ce usinagem } \\
\text { da mäquina }\end{array}$ & \\
\hline 3. & Desbaste & Fresà copiacora & $\begin{array}{l}\text { Definição do contomo, ceixando } \\
\text { sobrenetal para operação de aca- } \\
\text { bamento }\end{array}$ & $\begin{array}{l}\text { Méquine de eletroero } \\
\text { são }\end{array}$ & $\begin{array}{c}\text { Usinagem do bloco no regime de } \\
\text { desbaste }\end{array}$ & \\
\hline 4 & Acabamento & Fresa copiacora & $\begin{array}{l}\text { Ajuste da mäquina para acabamento. } \\
\text { operação cui dadosa }\end{array}$ & $\begin{array}{c}\text { Néquina de eletroero } \\
\text { são }\end{array}$ & $\begin{array}{l}\text { Fixaçäo do elëtrodo de acabamento } \\
\text { para usinagem nesse regime }\end{array}$ & \\
\hline 5 & $\begin{array}{l}\text { Abrasäo } \\
\text { superficial }\end{array}$ & - & - & $\begin{array}{c}\text { Bancada + ferramenta } \\
\text { abrasiva }\end{array}$ & $\begin{array}{l}\text { Acerto de raios. Diminuçäo da ca } \\
\text { mada superficial endurecida }\end{array}$ & \\
\hline 6 & $\begin{array}{l}\text { Abertura do a- } \\
\text { lojamento de } \\
\text { excesso ce ma- } \\
\text { terial na ma- } \\
\text { triz }\end{array}$ & Fresa copiacora & $\begin{array}{l}\text { Abertura co rasgo para alojar } \circ \\
\text { excesso de raterial }\end{array}$ & Fresa copiadora & $\begin{array}{l}\text { Abertura do rasgo para alojar o } \\
\text { excesso de material. }\end{array}$ & \\
\hline 7 & Ajustagem & Bancada & $\begin{array}{l}\text { Acerto de raios. Retirada das re- } \\
\text { barbas. Ajuste de dirensöes . fi- } \\
\text { nais }\end{array}$ & - & - & \\
\hline
\end{tabular}


convencional e está presente em ambos os blocos, seja naque le fabricado por UEE, seja naquele fabricado por fresamento por copiamento; seus tempos de fabricação e custo não foram computados nesta anälise.

Tab. 4.2 - Tempos de fabricação da matriz para cada processo utilizado

\begin{tabular}{|c|c|c|c|}
\hline \multicolumn{2}{|c|}{ FRESAMENTO POR COPIAMENTO } & \multicolumn{2}{|c|}{ USINAGEM POR ELETROEROSÃO } \\
\hline Operação & $\begin{array}{c}\text { Tempo } \\
\text { (h) }\end{array}$ & Operação & Tempo \\
\hline Traçagem e Montagem & 16 & Traçagem e Montagem & 5 \\
\hline $\begin{array}{l}\text { Eresamento de desbas } \\
\text { te, acabamento e a- } \\
\text { bertura de alojamen } \\
\text { to de excesso de ma- } \\
\text { terial }\end{array}$ & 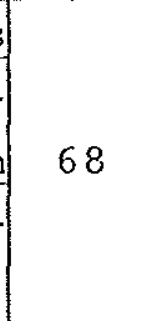 & $\begin{array}{l}\text { Usinagem de desbaste, } \\
\text { troca de elétrodo e y } \\
\text { sinagem de acabamento }\end{array}$ & 15 \\
\hline Ajustagem & 14 & Abrasão superficial & 18 \\
\hline- & - & $\begin{array}{c}\text { Abertura do alojamen- } \\
\text { to de excesso de mam } \\
\text { terial }\end{array}$ & 10 \\
\hline Tempo total $\left(\mathrm{T}_{t}\right)$ & 98 & $\left(T_{t}\right)$ & 48 \\
\hline
\end{tabular}

Depreende-se, da Tabela 4.2, que o tempo de fabricação da matriz por UEE é praticamente igual à metade do tempo gasto pelo fresamento, considerando-se que os elétrodos de desbas te e acabanento foram comprados prontos.

\subsubsection{Análise dos custos de Fabricação da Matriz}

Os investimentos de capital $\left(C_{i}\right)$ do fresamento por coplamento (FC) e da usinagem por eletroerosão (UEE) é descrito a seguir: 
- FC : Fresa copiadora pesada.. Cr\$10.850.000,00

- UEE : Máquina eletroerosiva... Cr $\$ 4.700 .000,00$

: Fresa copiadora leve.... Cr $\$ 3.550 .000,00$

Considerando-se um período de dez anos para amor tização do equipamento e uma capitalização periódica trimestral, à taxa de $2 \%$ ao trimestre, o fator de recuperação do capital, $F R C=0,03656$. Convém ressaltar que a correção monetária dos equipamentos será suposta igual para todos e les e, portanto, não será levada em conta nesta análise comparativa.

o custo horário do investimento é obtido empregando-se a fórmula 4.1

$$
C_{h i}=\frac{C_{i} \cdot F R C}{900}
$$

desde que os equipamentos trabalhem 900 horas por trimestre, cada um. Assim, vem:

$$
\mathrm{FC}: \mathrm{C}_{\mathrm{hi}}=\frac{10.850 .000,00 \times 0,03656}{900}
$$

ou seja:

$$
\begin{aligned}
\mathrm{C}_{\mathrm{hi}} & =\mathrm{Cr} \$ 440,75 / \text { hora } \\
\text { UEE : } \quad \mathrm{C}_{\mathrm{hi}} & =\frac{8.250 .000,00 \times 0,03656}{900}
\end{aligned}
$$

ou seja:

$$
c_{\text {hi }}=\operatorname{Cr} \$ 335,13 / \text { hora. }
$$

Considerando ainda um custo de mão-de-obra( $\left.\mathrm{C}_{\mathrm{hmo}}\right)$ de $\operatorname{cr} \$ 500,00 /$ hora, incluídas as obrigações sociais e demais despesas com o pessoal; um custo de preparação do blo co e aquisição do material $\left(\mathrm{C}_{\mathrm{pb}}\right)$ da ordem de $\mathrm{Cr} \$ 120.000,00$; um custo de cada um dos dois dispositivos porta-elétrodo ( $\mathrm{C}_{\mathrm{pe}}$ ) igual a $\operatorname{Cr} \$ 5.500,00$ e um custo de $\operatorname{Cr} \$ 26.000,00$ para cada e létrodo de grafite, de desbaste ou de acabamento $\left(\mathrm{C}_{\mathrm{ef}}\right), \mathrm{cu}$ ja vida útil $\left(v_{u e}\right)$ é de doze gravações $e$, portanto, seis 
matrizes, cada par de elétrodos, calcula-se o custo total. de fabricação para cada matriz $\left(\mathrm{C}_{\mathrm{T}}\right)$ :

$\underline{F C}: C_{\mathrm{T}}=\left(\mathrm{C}_{\mathrm{hi}}+\mathrm{C}_{\mathrm{hmo}}\right) \cdot \mathrm{T}_{\mathrm{t}}+\mathrm{C}_{\mathrm{pb}}$

Assim, o custo de fabricação por matriz,pelo pro cesso de fresamento por copiamento, $\mathrm{C}_{\mathrm{T}}$, de acordo com a fórmula 4.2 , vale:

$$
\begin{aligned}
& \mathrm{C}_{\mathrm{T}}=(440,75+500,00) \times 98+120.000,00= \\
& =212.193,50 \\
& \mathrm{C}_{\mathrm{T}}=\mathrm{Cr} \$ 212.193,50 \text { por matriz. } \\
& \text { UEE : } \quad C_{\mathrm{T}}=\left(\mathrm{C}_{\mathrm{hi}}+\mathrm{c}_{\mathrm{hmO}}\right) \cdot \mathrm{T}_{\mathrm{t}}+\mathrm{C}_{\mathrm{pb}}+\mathrm{C}_{\mathrm{N}}
\end{aligned}
$$

onde $\mathrm{C}_{\mathrm{N}}$ é um custo variável dos elétrodos e dos $\mathrm{n}$ dispositi vos de fixação dos $n$ tipos distintos de elétrodos, que depende do número $(N)$ de matrizes a ser fabricado:

$$
\mathrm{C}_{\mathrm{N}}=\frac{1}{\mathrm{~N}} \sum_{i=1}^{n}\left(j \cdot \mathrm{C}_{\mathrm{ef}}+\mathrm{C}_{\mathrm{pe}}\right)_{i}
$$

onde jé um número inteiro positivo que satisfaz às seguin tes condiçōes:

$$
\begin{aligned}
& \frac{\mathrm{N}}{\mathrm{V}_{\text {ue }}+1}<\mathrm{j} \leqslant \frac{\mathrm{N}}{\mathrm{V}_{\text {ue }}+1}+1 \\
& \text { Para o caso em análise, } \\
& \mathrm{C}_{\mathrm{T}}=(335,13+500,00) \times 48+120.000,00+\mathrm{C}_{\mathrm{n}}
\end{aligned}
$$

ou seja, a parcela do custo total $\mathrm{C}_{\mathrm{T}}$, de $\operatorname{Cr} \$ 160.086,24$, quando se utiliza a UEE, independe do número de matrizes fabricadas.

Se se pretende fabricar uma única matriz $(\mathrm{N}=1)$, - custo variável. $C_{n}$ será determinado utilizando-se as expressões 4.4 e 4.5 , levando-se em conta que: 
- Vida útil de cada jogo de elétrodos : $v_{\text {ue }}=6$ matrizes

- Tipos diferentes de elétrodos $: n=2$ (um de desbaste $(i=1)$ e outro de acabamento $(i=2)$ com seus respectivos dispositivos de fixação).

Assim, de acordo com a expressão $4.4,1 / 7<j<8 / 7$, ou seja, $j=1$ e a expressão 4.5 fica

$$
\mathrm{C}_{\mathrm{N}}=\left(\mathrm{C}_{\text {ef }}+\mathrm{C}_{\mathrm{pe}}\right)_{1}+\left(\mathrm{C}_{\text {ef }}+\mathrm{C}_{\mathrm{pe}}\right)_{2}
$$

ou seja,

$$
\begin{aligned}
& \mathrm{C}_{\mathrm{N}}=(26.000,00+5.500,00)+(26.000,00+5.500,00) \\
& \mathrm{C}_{\mathrm{N}}=\mathrm{Cr} \$ 63.000,00, \text { para a primeira matriz. }
\end{aligned}
$$

O custo total da primeira matriz fabricada nessas condições por UEE é de $C_{\mathrm{T}}=\mathrm{Cr} \$ 223,086,24$, superior por tanto àquele obtido pelo fresamento; contudo, a segunda ma triz fabricada por UEE custará a importância no valor de Cr $\$ 191.586,24$, pois utiliza as mesmas ferramentas e dispositivos empregados na usinagem da primeira matriz.

Apresenta-se na Figura 31 um gráfico comparativo do custo total de fabricação de u'a matriz para forjamento por UEE e por fresamento por copiamento.

Percebe-se claramente, pela análise do gráfico esboçado na Figura 31, que o ponto de nivelamento, ou seja, o ponto em que ambos os processos se equivalem, em ter mos do custo total de fabricação, situa-se entre $1<\mathrm{N}<2$.

Se se deseja fabricar uma unica matriz, é preferível fazê-la através de fresamento por copiamento; de duas matrizes em diante, torna-se mais econônica a fabricação por: UEE.

As descontinuidades da curva de custos do proces so eletroerosivo apresentam-se sempre que se introduz, na produção seriada de matrizes, um novo jogo de elétrodos; o dispositivo de fixação de cada elétrodo-ferramenta não sofre desgaste e seu custo é amortizado paulatinamente à medida em que $\underline{\mathrm{N}}$ aumenta. 


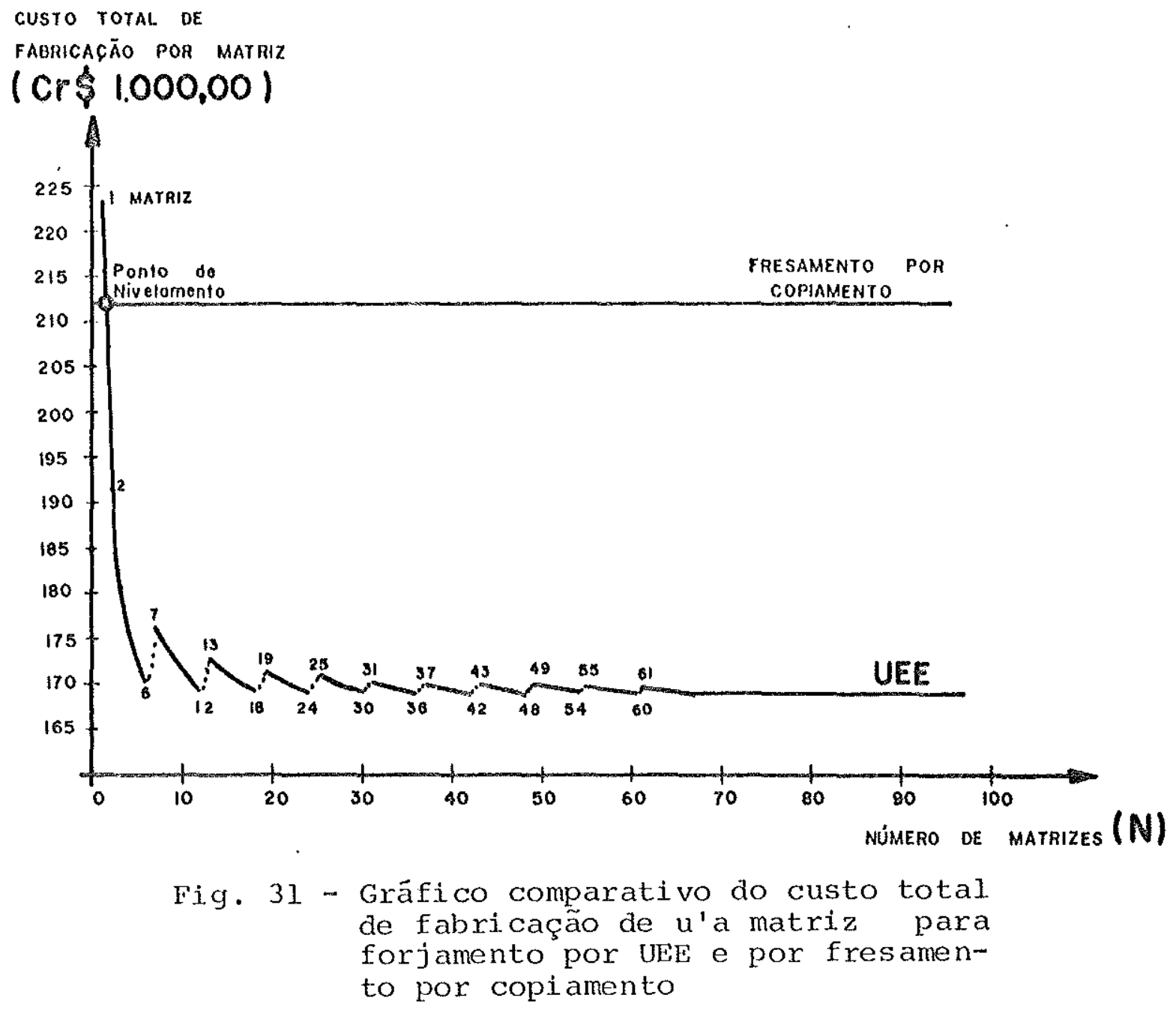

A análise comparativa aqui efetuada mostra clara mente que o processo de usinagem por eletroerosão é economicamente viável na fabricação de matrizes, o que o creden cia como um processo de fabricação não-convencional realmente competitivo, em termos industriais. 
5. PARAMETROS TECNOLOGICOS DO PROCESSO

5.1. Generalidades

A produção de una determinada configuração através da usinagem por eletroerosão exige inúmeras considerações no projeto do elétrodo-ferramenta. A maioria das apli cações industriais do processo utiliza principalmente o mé todo da tentativa-e-erro nesse projeto. Isso decorre do grande número de variáveis e alternativas possíveis de ope ração, diferentes para cada combinação de materiais consti tuintes dos elétrodos.

Considerar-se-ão, aqui, os principais parâmetros característicos da operação e/ou cuja influência tem sido constatada através de dados e conhecimentos empíricos obtidos por pesquisadores e usuários do processo nas três úl timas décadas, como Lazarenko, Opitz, Livschitz, Zolotich, Crookal1, Mi ronoff, Yamagutti, Karafuji, Lascoe, Marty, Ryabov e Sosenko, dentre outros.

Para maior clareza de análise, os parâmetros do processo foram agrupados segundo as sequintes classes: 
- 5.2 - PARÁMETROS ELETRICOS

- 5.3 - PARÂMETROS TERMODINÂMTCOS

- 5.4 - PARÂMETROS HIDRODINÂMICOS

- 5.5 - PARÂMETROS METALORGICOS

- 5.6 - PARÁMETROS MECÂNICOS

. 5.7 - PARAMETROS GEOMETRICOS.

De acordo com a aplicação e as condições de usinagem empregadas, cada uma das classes acima assume uma maior ou menor relevância no contexto global do processo e letroerosivo.

\subsection{Parâmetros Elétricos}

Em todas as operações de usinagem por elletroerosão, a seleção dos parâmetros elétricos dos circuitos de carga e descarga depende literalmente do tipo e possibilidades do gerador elétrico utilizado, como foi salientado no capítulo anterior.

Dentre as grandezas mais importantes dessa classe, destacam-se as seguintes:

. 5.2.1 - Energia da Descarga

- 5.2.2 - Corrente da Descarga

- 5.2.3 - Frequência de Descargas

- 5.2.4 - Resistividade dos Elétrodos

- 5.2.5 - Polaridade do Circuito

- 5.2.6 - Propriedades Dielétricas do Fluido de Servi.ço.

\subsubsection{Energia da Descarga}

As magnitudes da erosão da peça e do desgaste do elétrodo-ferramenta dependem da distribuição de energia su prida pela corrente elëtrica, ou seja, como essa energia é 
distribuida entre os diversos componentes do sistema (peça, elétrodo-ferramenta e fluido dielētrico) e entre vărias modalidades de energia (térmica, elétrica, química etc.)

No início do processo, a energia é distribuída principalmente ao longo do canal de descarga e às micro-re giões superficiais dos elétrodos. À medida que a profundi.dade de corte aumenta paulatinamente, durante a usinagem, a distribuição de energia da descarga varia continuamente em termos da energia conduzida, energia armazenada e energia utilizada na erosão da peça e no desgaste indesejävel. do elétrodo.

Apenas a energia armazenada e a energia diretamente conduzida são distinguidas no fluido dielétrico. A parcela remanescente da energia da descarga, que não pode ser transferida para nenhum elemento particular do sistema como um todo, assume diversas formas de energia, seja como radiação térmi ca ou ionização, seja ainda como luz ou som.

A forma e duração dos impulsos comandados pelo gerador eletroerosivo devem se concebidas de modo a adequar a energia da descarga às condições exigidas por cada usinagem específica. Nisso reside a principal limitação dos geradores de relaxação, pois, nesses gexadores, a ener gía da descarga é uma função direta da carga armazenada por capacitores,

$$
\mathrm{E}=\mathrm{C} \cdot \mathrm{V}^{2} / 2
$$

e não hã como variar a forma dos pulsos ali gerados. Além do mais, para uma tensão de descarga constante, a variação da energia da descarga implica inevitavelmente na variação da frequência de descargas, também dependente do valor da capacitância do cixcuito de descarga e do espaçamento entre a peça e o elétrodo-ferramenta, nos geradores de relaxação. Nos geradores modernos tais parâmetros podem ser re gulados isoladamente. 
De u'a maneira geral, a energia da descarga é

matematicamente definida pela equação:

$$
E=\int_{0}^{t} d(t) \cdot i(t) d t
$$

isto é, o produto da tensão pela corrente, integrado em um intervalo de tempo iq̣ual ao da duração da descarga.

A velocidade de remoção de material, sendo uma função da energia de descarga, depende por conseguinte da tensão, corrente e duração da descarga. Se, por um lado, a majoração desses parâmetros é altamente desejável para permitir uma redução significativa do tempo total de usinagem, por outro enseja uma sensível redução da qualidade de acabamento, bem como um aumento substancial nos custos de investimento.

\subsubsection{Corrente de Descarga}

Pode-se controlar o consumo de energia do processo eletroerosivo com o auxilio de um amperimetro, desde que se conheçam as relações empíricas entre a energia média fornecida à zona de serviço e a corrente média de um pulso (em um período de tempo $\mathrm{T}$ ), as dimensões da área usinada e a densidade de corrente utilizada, para uma velocidade de remoção de material obtida a bandas de frequência de descargas conheciclas.

A relação entre a corrente de descarga, I, e a área da seção transversal de uma superfície condutora, $s$, $\vec{e}$ conhecida como densidade de corrente, $\delta$ :

$$
\delta=I / S
$$

Quando a corrente começa a fluir no "gap", no $\underline{i}$ nício de um pulso, o canal de condutibilidade é muito esbelto e a densidade de corrente é correspondentemente alta, produzindo temperaturas muito elevadas. Ã proporção 
que a carga continua, o canal de condutibilidade dilata-se gradualmente e a densidade de corrente diminui. Entre esses dois limites, há a máxima erosão da peça, em um pulso. A Figura 32 ilustra a variação da corrente da descarga, no tempo, para um pulso curto e um pulso longo. Deduz-se, in loco, que as operações de desbaste e acabamen to exigem pulsos longo e curto, respectivamente, para valo res próximo do pico de corrente. O valor da corrente de descarga pode ser controlado pelo operador da máquina, para que se obtenham as conđições mais apropriadas para cada usinagem específica.

\section{COABENTE}

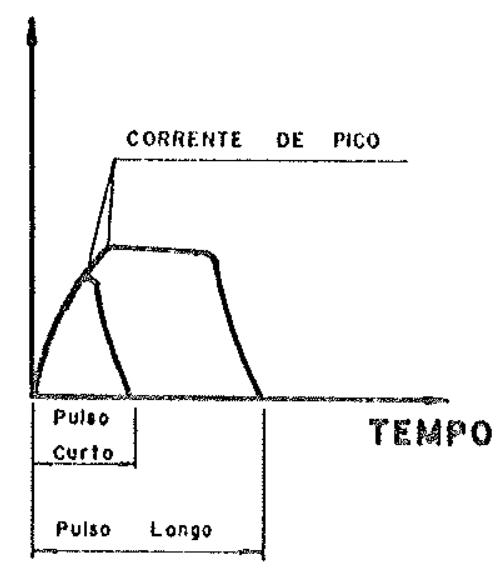

Fig. 32 - Variação da corrente de descarga, no

Para baixos valores da densidade de corrente, a capacidade erosiva é pequena, enquanto para valores mais e levados, a estabilidade do processo é comprometida e a energia utilizada na erosão é uma pequena parcela da energía da descarga.

A corrente da descarga é determinada pelas possi bilidades e limitações do gerador eletroerosivo. A sua mag nitude exprime a potencialidade de um gerador eletroerosi- 
vo. Atualmente, as mäquinas UEE de maior porte utilizam ge radores de até $600 \mathrm{~A}$.

\subsubsection{Frequência de Descargas}

A Figura 33 mostra a variação da tensão, no tempo, através do "gap" de usinagem. Uma vez completada a des carga, a tensão no "gap" mantém-se em um valor inferior à tensão de descarga até que a desionização se complete. o tempo necessário à desionização do "gap" depende de forma direta do valor da energia da descarga anterior. A soma dos tempos de duração da descarga e de desionização do "gap" resulta no tempo total do ciclo e, pois, determina a frequência de descargas de uma magnitude particular.

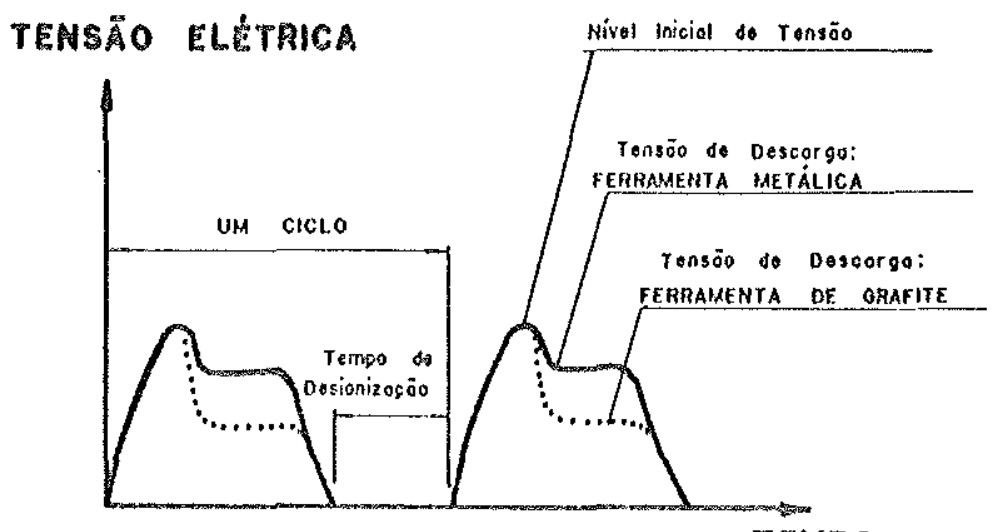

TEMPO

Fig. 33 - Variação da tensão no "gap" de serviço, no tempo ${ }^{3}$

A frequência de descargas influi no volume de ma terial erodido e nas características estruturais de uma pe quena regíão vi.cinal à cratera usinada.

A experiência tem mostrado que hä dificuldades em se manter constante a frequência de descargas em consequência das interrupōes momentâneas do processo de usinagem devido às flutuações de posicionamento do cabeçote por ta-ferramenta, servo-comandado. Além do mais, a maioria 
dos circuitos de usinagem que equipam as máquinas UEE não permite conservar estritamente constantes os parâmetros energéticos da descarga durante toda uma usinagem.

Sob certos limites, duplicando-se a corrente da descarga e a frequência de descargas, a velocidade de remo ção de material tambëm duplica, sem alterações significatị vas no acabamento superficial. A altas frequências, a corrente da descarga é reduzida devido à indutância, diminuin do consequentemente a velocidade de remoção de material. Como altas frequências ensejam melhores acabamentos superficiais, há um limite prático, de cunho econômico, na sele ção adequada da corrente e da frequência de descargas para cada aplicação.

\subsubsection{Resistividade dos Elëtrodos}

As exigências fundamentais de projeto, na concep Ção de um produto, incluem a especificação do material ou materiais de que deverá ser constituído. $\AA$ engenharia de fabricação, reserva-se o critério da seleção do material ou materiais de cada elétrodo-ferramenta.

Assim, não há como alterar a resistividade da pe ça, uma característica intrínseca de cada material.

o critério da seleção do material do elétrodo- ferramenta deve levar em conta a sua resistividade, bem co no o comportamento dessa resistividade ante às variações de temperatura desenvolvidas no processo eletroerosivo.

A energia da descarga, para um determinado nível. de tensão elétrica, é transmitida pelo elétrodo-ferramenta à peça usinada pela corrente da descarga, de acordo com as peculiaridades do líquido dielétrico e da estrutura interna de cada um dos elétrodos em serviço; uma destas, a resistividade, deve ser tão baixa quanto possível, para ense jar uma melhor condução elétrica e uma distribuição eficiente da corrente. 
Os metais puros possuem as mais baixas resistivi dades. Entretanto, qualquer impureza, seja metálica ou não - metálica, aumenta a resistividade de um metal, independen temente da resistividade dessa impureza ser maior ou menor que aquela do metal puro em questão.

Os valores da resistividade dos metais, à temperatura de $20^{\circ} \mathrm{C}$, variam desde $0,016 \mu \Omega \mathrm{m}$ (prata) até aproxi madamente $10 \mu \Omega m$ (ligas ferro-cromo-alumínio); a resistivi dade do cobre è de $0,01.7 \mu \Omega \mathrm{m}$. Outros tipos de materiais, co mo o cobre-grafite, possui resistividade mínima de 0,030 $\mu \Omega \mathrm{m}$, enquanto a do grafite é de $8 \mu \Omega \mathrm{m}$. O seu uso como elétrodo-ferramenta é justificado por possuir um ponto de fusão muito elevado (cerca de $3.900^{\circ} \mathrm{C}$ ).

\subsubsection{Polaridade do Circuito}

E outra variável importante na UEE. A polaridade normal, ou positiva, do circuito de descarga, é definida pela aplicação de uma diferença de potencial elétrico ao sistema, criando um campo elétrico em que o elétrodo-ferra menta é o cátodo e a peça, o ânodo.

A polaridade positiva é utilizada quando o parâmetro de maior interesse é a velocidade de remoção de mate rial, ainda que seja em detrimento do desgaste do elétrodo -ferramenta.

A polaridade invertida, como o próprio nome o su gere, é definida pela inversão do sentido normal de fluxo de corrente elétrica; neste caso, o elétrodo-ferramenta é o ânodo e a peça, o cätodo. Sob essas condições, a velocidade de remoção de material diminui, mas o desgaste do elé trodo-ferramenta é muito pequeno devido ao fenômeno de "crescimento" do elétrodo-ferramenta, em que algumas partí culas removidas da peça "soldam-se" desordenadamente à superfície da ferramenta. 
A propriedade mais importante de um fluido dielé trico é a sua baixa condutibilidade elétrica (alta resisti vidade). Na UEE, o fluido dielétrico de serviço isola a ferramenta e a peça, que estão a diferentes potenciais elé tricos, formando com eles um capacitor: o "gap" de usinagem.

Além de isolar o elétrodo-ferramenta e a peça, o fluido dielétrico refrigera a zona de usinagem e os elétro dos, exercendo simultaneamente uma ação de remoção das par tículas erodidas dessa zona de usinagem.

Um bom líquido dielétrico, em UEE, deve apresentar as seguintes características:

- resistência dielétrica suficiente para isolar o elétrodo e a peça; deve deixar passar corren te apenas sob a forma de descargas (baixas per das dielétricas);

- baixa inflamabilidade;

- mínima variação das suas propriedades em todas as condições de usinagem, temperatura, contami nação do dielëtrico etc.;

- propriedades quimi camente neutras, para não atacar a peça, a ferramenta, o equipamento, nem tampouco o operador;

- viscosidade baixa, para melhor executar as suas funções na zona de usinagem;

- ausência de formação de vapores ou com odor de sagradāve1.

Basicamente, se utilizam hidrocarbonetos e água desionizada como fluido de serviço. Dentre todos os fluidos dielétricos, contudo, o querosene tem sido o mais lar- 
gamente utilizado nos equipamentos de usinagem por eletroerosão, pelas suas características em serviço.

A composição do querosene é a seguinte: $86,3 \% \mathrm{C}$, $13,6 \% \mathrm{H}$ e $0,08 \% \mathrm{~S}$. A $20^{\circ} \mathrm{C}$, ele possui u'a massa especifica de $793 \mathrm{~kg} / \mathrm{m}^{3}$ e uma viscosidade cinemática de $0,0160 \mathrm{st}$; seu calor específico médio, entre 0 e $100{ }^{\circ} \mathrm{C}$, é de 500 $\mathrm{cal} / \mathrm{g}{ }^{\circ} \mathrm{C}$.

Um fator negativo da utilização do querosene como fluido dielëtrico é o seu odor desagradāvel em serviço, exigindo uma exaustão eficiente do ar ambiental e uma circulação de ar fresco no recinto de trabalho.

\section{3. parâmetros Termodinâmicos}

A remoção de material por eletroerosão deve-se, em grande parte, à fusão e/ou vaporização do metal pelo ca lor gerado próximo à superfície dos elétrodos. Isso tem mo tivado diversas pesquisas nossa área, destacando-se os tra balhos de Van Dijck ${ }^{13}$, Van Dijck e Snoeys ${ }^{14^{4}}$ e Marty $^{15}$, que concluíram que o suprimento de vapor metálico no canal de plasma é assegurado durante todo um pulso de descarga, devido às pequenas flutuações na tensão de descarga.

E, pois, importante, familiarizar-se com os parâ metros termodinâmicos mais significativos do processo eletroerosivo, para uma melhor compreensão da sua influência sobre o desempenho da usinagem.

Dentre os parâmetros concernentes aos elétrodos, destacam-se os seguintes:

- pontos de fusão e de ebulição

- condutibilidade térmica

- difusividade térmica.

A cada material associa-se uma dessas grandezas. E desejável que a relação entre os pontos de fusão e de ebulição da peça e do elétrodo-ferramenta seja sempre menor 
que a unidade; isso reduz significativamente o desgaste da ferramenta. Baixos pontos de fusão e ebulição da peça inau zem a altas velocidades de remoção de material, enquanto al tos pontos de fusão e ebulição do elétrodo-ferramenta asse guram um menor desgaste desse componente.

A condutibilidade térmica dos elétrodos exprime a sua capacidade de conduzir calor; a difusividade é a medida da sua inércia térmica e, portanto, é um parâmetro im portante nos processos transientes de transmissão de calor, como na UEE, por exemplo.

A condutibilidade térmica de metais puros diminui sensivelmente com a presença de impurezas e com a elevação da temperatura; nas ligas metálicas, a condutibilida de térmica aumenta com a elevação da temperatura.

o elétrodo-ferramenta ideal deve possuir ótimas características de transmissibilidade, térmica e elétrica. E essencial, para isso, possuir um elevado coeficiente de condutibilidade tërmica e de difusividade.

o fluido dielétrico, por sua vez, devido às necessidades de um elemento refrigerante na UEE, deve assegu rar a manutenção da temperatura de serviço em uma faixa com pativel com os níveis energéticos da descarga, com a infla mabilidade do dielétrico e com a acuracidade da usinagem e xecutada.

Lascoe ${ }^{16}$, analisando a influência da temperatura do dielétrico sobre o processo de usinagem, observou que maiores velocidades de remoção de material são obtidas a baixas temperaturas do banho dielétrico $\left(10^{\circ} \mathrm{C}\right)$, assim como o avanço linear da ferramenta é mais uniforme; em contrapartida, melhores relações de desgaste consequem-se a temperaturas mais altas do dielétrico $\left(30^{\circ} \mathrm{C}\right)$. De acordo com o parâmetro mais importante para cada aplicação, seleciona-se a faixa de temperatura mais conveniente. Para isso, é preciso que o fluido dielétrico assegure uma refrige ração eficiente da zona de usinagem, mantendo simultaneamente as suas características operacionais confiāveis. 


\subsection{Parâmetros Hidrodinâmicos}

A usinagem por eletroerosão é, por excelência, um processo de fabricação de colóides. Em muitos aspectos, a ciência dos colóides é de notável complexidade e o assun to não pode, diversas vezes, ser tratado com a exatidão as sociada a determinados ramos da físico-química, até porque o emprego de materiais de composição até certo ponto duvidosa introduz considerável incerteza na reprodutibilidade e interpretação final dos resultados.

Um fato, porém, é certo: deve haver, durante a $\underline{u}$ sinagem eletroerosiva, uma remoção incontinenti das partículas coloidais do "gap" de serviço. Diversos experimentos têm mostrado que a natureza e a concentração de partículas sölidas no "gap" influenciam significativamente a velocida de de remoção de material e o desgaste do elétrodo-ferra-menta.

Vajta et alii. ${ }^{17}$, Hockenbury ${ }^{18}$, De Bruyn ${ }^{19}$, LasCoe $^{16}$, Karafuji e Suda ${ }^{20}$ Crookal1 $1^{21}$, dentre outros, anali saram aspectos relacionados com o fluido dielëtrico e sua influência sobre as condições de usinagem, a peça e o elétrodo-ferramenta utilizado, constatando que deve haver uma circulação eficiente do fluido dielétrico entre a ferramen ta e a peça, para que se obtenham os melhores rendimentos nos diversos regimes de usinagem.

A lavagem é a circulaçäo forçada do fluido dielé trico no "gap" entre os elétrodos, de modo a remover as partículas de material erodido. Diferentes tipos de lavagem podem ser empregados conforme os problemas a tratar:

- por injeção

- por aspiração ou suç̧ão

- por injeção lateral

- combinada

- por injeção pulsada sincronizada. 
A lavagem por injeção do fluido dielétrico se efetua via uma "câmara de lavagem" (um copo metálico posicionado sob a peça usinada) ou via um furo central executa do no próprio elétrodo. No primeiro caso, figura 34-a, a peça é pré-furada e montada sobre a câmara de lavagem, aco plada às tubulações. No segundo caso, Figura 34-b, o elétrodo-ferramenta é furado e o dielétrico jorra através des se duto.

A lavagem por injeção permite obter lavagens 1igeiramente cônicas por meio de elétrodos de perfil constan te. Esse efeito de conicidade é provocado pelas partículas que se elevam ao longo das laterais do elétrodo-ferramenta, favorecendo assim as descargas laterais.

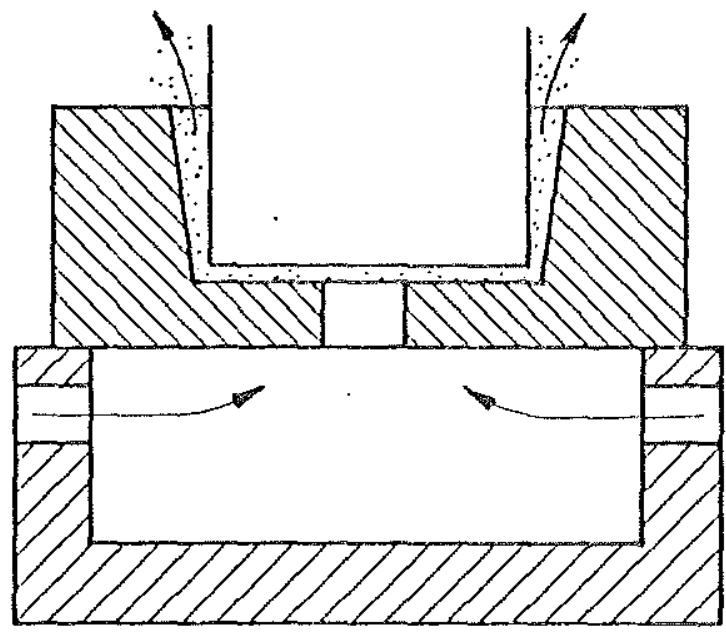

(a)

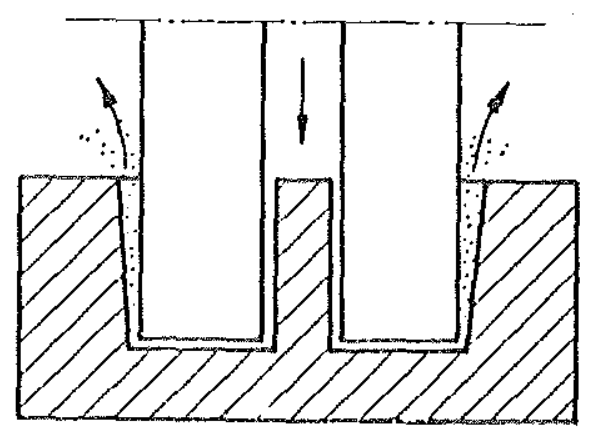

(b)

Fig. 34 - Lavagem por injeção do fluido dielêtrico

A lavagem por aspiração ou sucção consiste em as pirar o líquido dielétrico da zona de usinagem por meio de uma câmara de lavagem (Figura 35-a) ou pelo orifício central do elétrodo (Figura 35-b).

Reduzindo o movimento de partículas erodidas do "gap" lateral, a lavagem por aspiração permite que se obte nham usinagens com uma conicidade baixíssima. o acúmulo 
de gases na câmara de lavagem, provenientes da usinagem, pode ser eliminado assegurando-se um fluxo dielétrico contínuo pela câmara de lavagem, através da determinação criteriosa da pressão vacuométrica de sucção e da vãão do $1 \underline{\text { á }}$ quido aspirado.

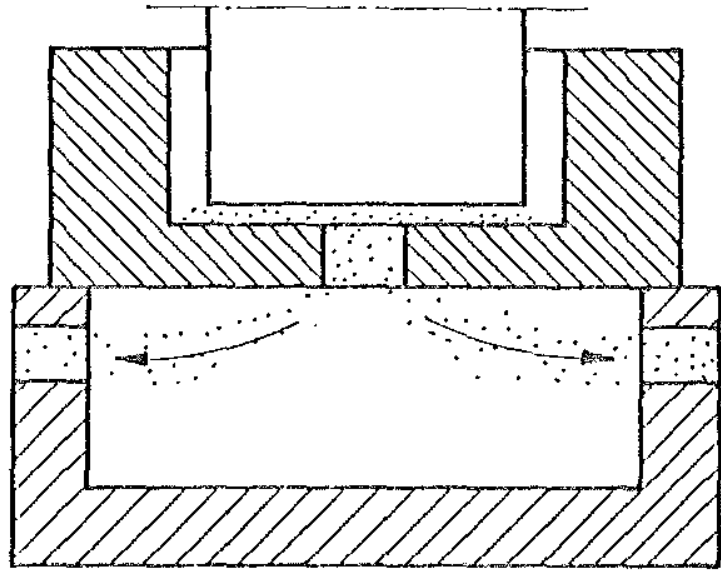

(a)

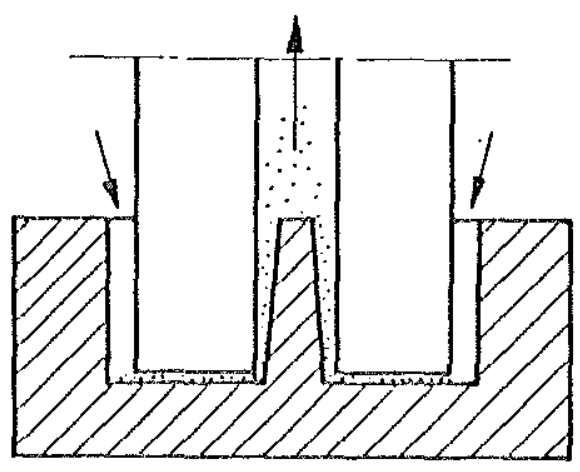

(b)

Fig. 35 - Lavagen por aspiração do fluido dielétrico

Os gases provenientes da usinagem e acumulados na câmara de lavagem exercem um efeito de martelamento sobre a peça usinada, podendo inclusive deslocá-la da sua po sição predeterminada.

Quando se apresenta a impossibilidade de se executar furos de lavagem no elétrodo-ferramenta ou na peça, recorre-se à lavagem por injeção lateral do dielétrico (Fí gura 36). Essa tëcnica pode ser empregada utilizando-se uma pulsação sincronizada do cabeçote; periodicamente, o cạ beçote é servoafastado da zona de usinagem e um ou mais ja tos de fluido são dirigidos à peça, removendo as partículas erodidas; após um tempo regulável, o cabeçote retorna à posição de trabalho, reiniciando o processo de usinagem e, assim, sucessivamente. 


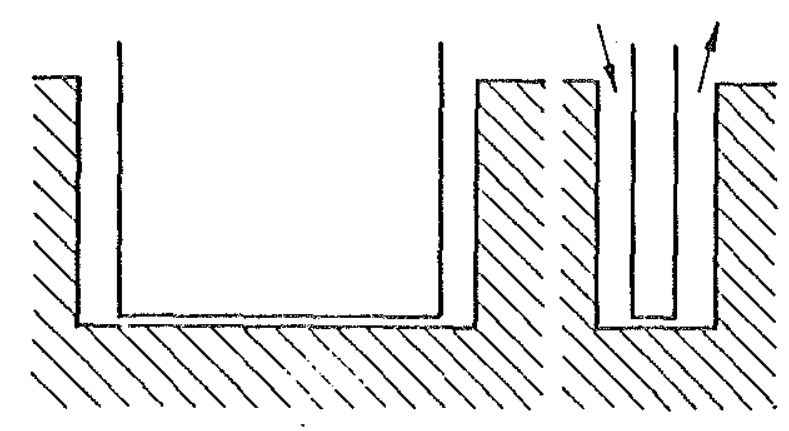

Fig. 36 - Lavagem por injeção lateral do fluido dielétrico

Finalmente, pode-se combinar a injeção e a aspiração do dielétrico para executar uma lavagem eficiente em peças de formato complicado. Ela permite a evacuação do gás e das partículas erodidas através de uma circulação, do fluido dielétrico, mais regular.

os aspectos hidrodinâmicos da circulação forçada do dielétrico na zona de usinagem assumem uma relevância capital à estabilidade do processo eletroerosivo, ao desgaste da ferramenta, ao sobrecorte, à conicidade e ao acabamento superficial da peça usinada.

Os principais parâmetros hidrodinâmicos que devem ser analisados em UEE são os seguintes:

- massa específica do fluido dielétrico

- viscosidade do fluido dielétrico

- pressão de recalque do fluido dielétrico para o reservatório de serviço

- vazão de entrada do fluido dielétrico no reser vatório de serviço

- vazão de entrada do fluido dielétrico injetado diretamente na zona de usinagem 
- vazão de saída do flujdo dielétrico aspirado da zona de usinagem

- pressão manométrica de injeģão do dielétrico na zona de usinagem

- pressão vacuométrica de suç̧ão do dielétrico na zona de usinagem

- distribuição da temperatura do banho dielétri$\mathrm{CO}$

- perdas de carga devido às geometrias dos elétrodos; à contaminação do dielétrico no "gap" de serviço e aos tipos de furos de lavagem exe cutados nos elétrodos.

o equacionamento das leis que regem as variações desses parâmetros listados é extremamente complicado e moroso; contudo, minimizam-se estas dificuldades através de hipóteses simplificadoras.

\subsection{Parâmetros Metalúrgicos}

A homogeneidade é um estado ideal que assegura a um determinado material as mesmas propriedades em toda a sua configuração geomëtrica. Os materiais correntemente utilizados, entretanto, não são homogêneos. A veracidade des sa assertiva, na prätica, é constatada pela variação das propriedades de um mesmo material segundo diferentes planos, tomados em relação a um sistema referencial de coorde nadas.

Elétrodos metálicos fabricados a partir de materiais trabalhados a frio são um exemplo clássico da ocorrência desse fenômeno. Propriedades relevantes à UEE, como as condutibilidades elëtrica e térmica, assumem valores mui to distintos entre si segundo dois planos ortogonais. Nos grafites, as dispersões entre esses valores são ainda maio res.

Durante a fabricação dos elétrodos, deve-se le- 
var em conta a orientação correta a ser adotada, para que haja uma compatibilidade entre o plano de mínima resistivi dade elétrica e a direção do fluxo da corrente de descarga. Com isso, obtêm-se maiores velocidades de remoção de material e minoração do efeito das descargas laterais.

O tamanho do grão dos elétrodos também influi no processo UEE. Porto e Cupini ${ }^{2}$, usinando alumínio de diferentes tamanhos de grãos com elétrodos de grafite, constataram que existe uma melhoria de usinabilidade quando se trabalha com estrutura de grãos finos.

o desenvolvimento de calor na zona de usinagem

altera as propriedades de uma camada superficial delgada da peça usinada. Parte da energia da descarga é convertida em calor e isso provoca um tratamento térmico no material; a zona afetada pelo calor tem uma profundidade compatível. com o regime de usinagem utilizado.

A experiência tem mostrado que a resistência à fadiga de peças eletroerodidas é menor que a das peças usi nadas por processos convencionais. Isso se deve às modificações estruturais que ocorrem na superfície da peça duran te a UEE.

\subsection{Parâmetros Mecânicos}

O servo-sistema de comando do avanço do cabeçote porta-elëtrodo é o elemento responsável pela manutenção do "gap" entre o elétrodo e a peça, de modo a permitir que a descarga se efetue a um nível de tensão predeterminado pois, durante a usinagem, tanto a peça, como a ferramenta, são erodidas.

A velocidade de avanço do cabeçote é um parâmetro mecânico decisivo no desempenho eficiente da usinagem. De acordo com a área usinada, o dielëtrico usado, os materiais dos elëtrodos, a energia e a frequência de descargas, a velocidade de avanço do cabeçote determina a velocí dade de remoção de material e a estabilidade do processo. 
Qualquer defasagem entre a velocidade de avanço do cabeçote a a velocidade com que as partículas são erodidas induz a um baixo aproveitamento da energia de descarga.

A rigidez do conjunto mecânico da máquina-ferramenta UEE é igualmente importante à precisão de movimento do cabeçote porta-ferramenta em relação à peça.

\subsection{Parâmetros Geométricos}

A seleção das condições mais propícias ao desenvolvimento da UEE deve levar em conta, finalmente, os parâ metros geométricos do processo:

- área a ser usinada

- profundidade de usinagem

- geometria da cavidade

- conicidade

- rugosidade superficial da peça usinada

- sobrecorte

- desgaste do elétrodo-ferramenta.

Cada um dos parâmetros acima assume uma importân cia correlata com o regime de usinagem utilizado, com a acuracidade e com os custos do processo, variáveis para cada apli cação.

A quantificação da influência dos parâmetros tec nológicos sobre a UEE é um tema ainda em aberto e que exige uma abordagem dinâmica de todo o conjunto de variáveis envolvidas, o que não deixa de ser um desafio aos pesquisa dores da área. 
6. ANALISE EXPERTMENTAI, DA USINAGEM DE ACO-CARBONO POR ELE TROEROST̃O. RESULTNDOS OBTITDOS

\subsection{Generalidades}

A maioria dos fatores que influem no desempenho do processo uEE foi analisada nos capítulos iniciais deste trabalho. Salientou-se a importância dos diversos parâmetros tecnológicos sobre as características do processo,bem como os principais tipos de máquinas e geradores UEE desen volvidos em escala industrial.

Restringe-se, este capítulo, à análise experimen tal da usinagem de aço-carbono com elétrodos-ferramentas de cobre em u'a máquina UEE de relaxação que utiliza quero sene como fluido dielétrico.

Em u'a mãquina dessas, a tarefa do usuário fica restrita à seleção do regime de usinagem, configurado pelas características eletricas do circuito escolhido - resistência, capacitância, indutância, polaridade e tensão de ajuste determinada. Feito isso, adequa-se à aplicação o ti 
po mais conveniente e exequível de lavagem e a pressão manométrica (ou vacuométrica) de injeção (ou sucção) do flui do dielétrico deve ser a mínima capaz de ensejar a remoção das partículas dispersas na zona de usinagem porque, aumen tando-se o seu valor, verifica-se um maior desgaste do elé trodo-ferramenta metálico.

\subsection{Descrição do Equipamento Eletroerosivo Utilizado}

A Figura 37 mostra uma vista parcial da máquina UEE, utilizada na fase experimental deste trabalho. Ela possui gerador do tipo relaxação, $20 \mathrm{~A}$, é fabricada pela Hiteka, de procedência hüngara, sendo do tipo Erosimat D-01/A; caracteriza-se por uma potência de $10 \mathrm{KVA}$ e um sex vo-sistema de comando eletro-hidráulico do avanço do cabeço te porta-elëtrodo.

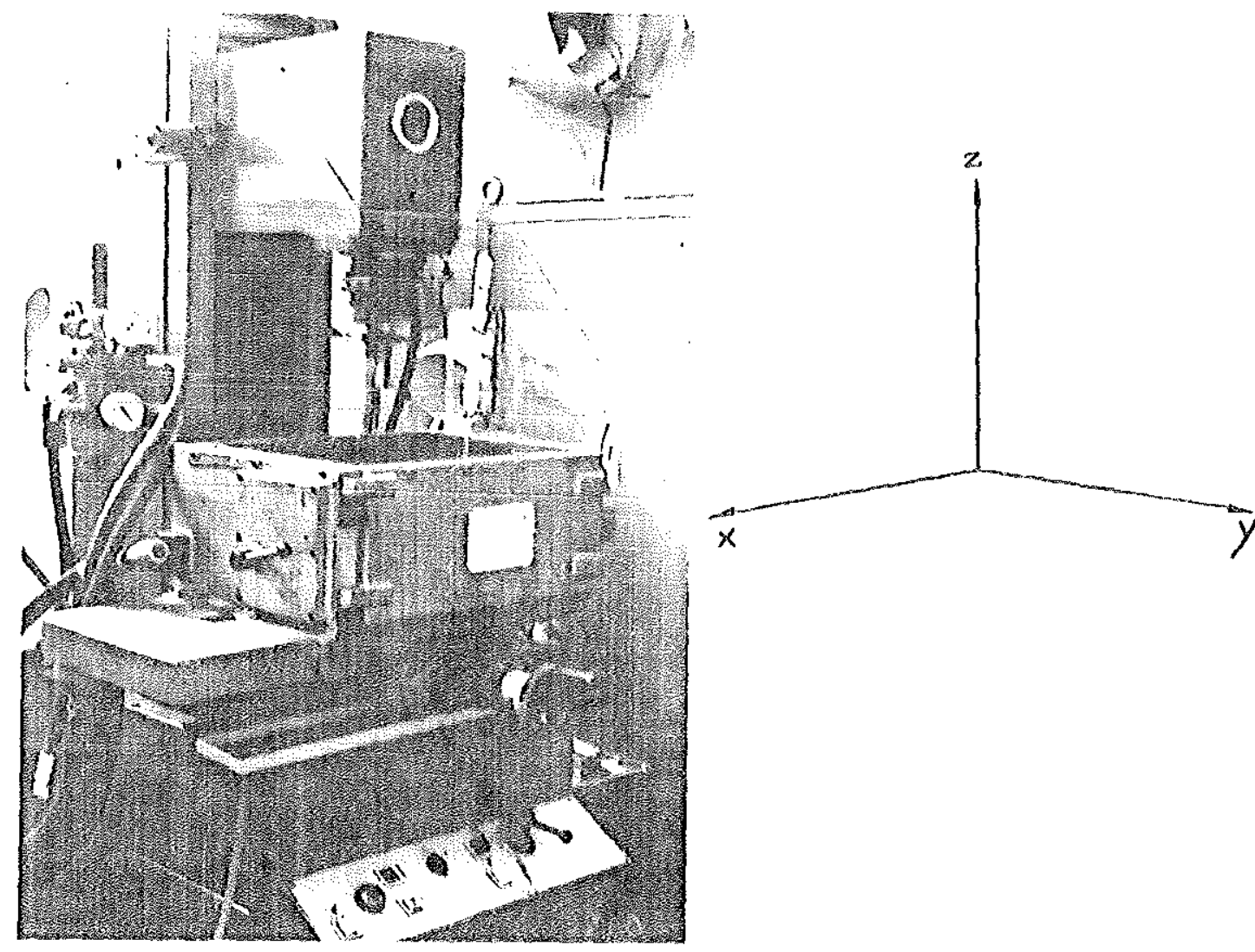

Fig. 37 - Vista da máquina-ferramenta eletrosiva Erosimat D-01/A, da Hiteka 
A Figura 38 apresenta o cabeçote porta-elëtrodo, energizado via o cabo de conexão elëtrica mostrado pela figura. O dispositivo de fixação do elëtrodo-ferramenta si tuado na parte inferior do cabeçote foi projetado e construído para possibilitar desvios de perpendicularismo da ordem de, no mäximo, 0,02/100 nm, entre o movimento do elé trodo-ferramenta (eixo dos "z", no sistema de coordenadas cartesianas) e a mesa de coordenadas, em operação.

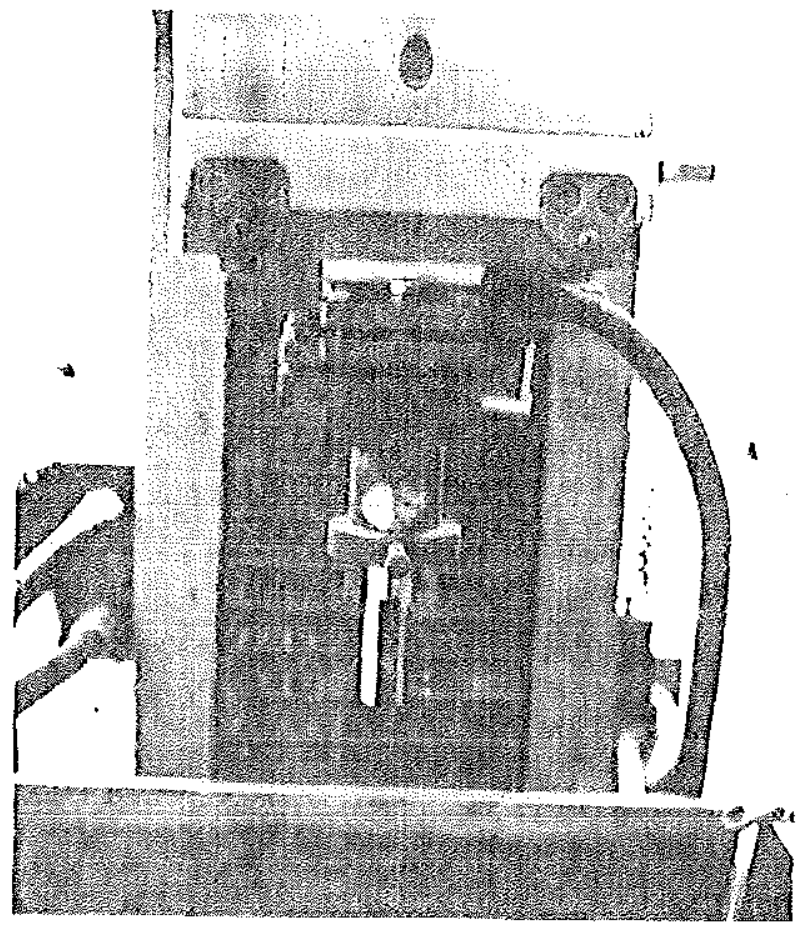

Fig. 38 - Cabeçote porta-elétrodo e dispositivo de fixação do elétrodo-ferramenta

A mesa de coordenadas utilizada nos ensaios caracteriza-se pelos seguintes desvios:

- Desvios de planicidade (eixos "x" e "y"): $0,03 / 1000 \mathrm{~mm}$

- Desvios de paralelismo entre a superfície ativa do elétrodo-ferramenta e a mesa de coordena das: $0,02 / 200 \mathrm{~mm}$ 
- Desvios de perpendicularismo entre os eixos " $x$ " e " $y$ " da mesa de coordenadas: 0,01/100 mm

- Deflexão do cabeçote durante o movimento: $0,04 / 300 \mathrm{~mm}$.

A precisão final da peça usinada por eletroerosão depende intrinsecamente dos valores acima especificados para os desvios de forma e posição. A análise detalhada dos mesmos revela a alta acuracidade do conjunto mecâni co da máquina-ferramenta eletroerosiva empregada nos ensaios, comparävel às máquinas-ferramenta mais precisas no âmbito da usinagem convencional.

o gerador elétrico, por sua vez, é construído na forma de blocos de montagem normalizados (Figura 39), que é de concepção moderna e garante fácil acesso e troca de com ponentes danificados ou curto-circuitados. Ele compreende os circuitos de operação das demais unidades (máquina-ferramenta eletroe rosiva, unidade de alimentação do dielétrico e unidade de alimentação do circuito hidráulico de comando e acionamento do cabeçote portamelétrodo) e os circuitos de relaxação, exigidos para a usinagem propriamente dita.

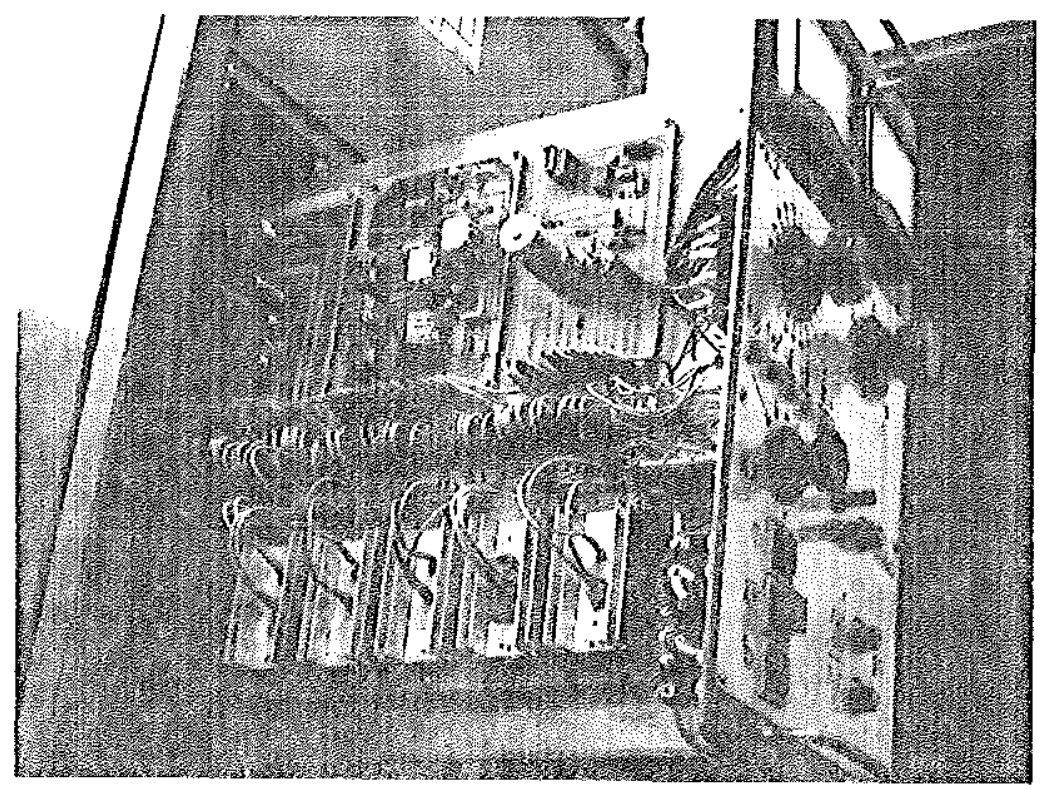

Fig. 39 - Bloco de montagem normalizado do gerador elëtrico 
Nas Figuras 40 e 41 , apresentam-se, respectivamente, o painel de comando do circuitos de relaxação, situado no gerador elétrico e o painel de comando do cabeçote, situado na máquina-ferramenta eletroerosiva; ambos se di.stinguem pela sua simplicidade de operação e fácil acesso.

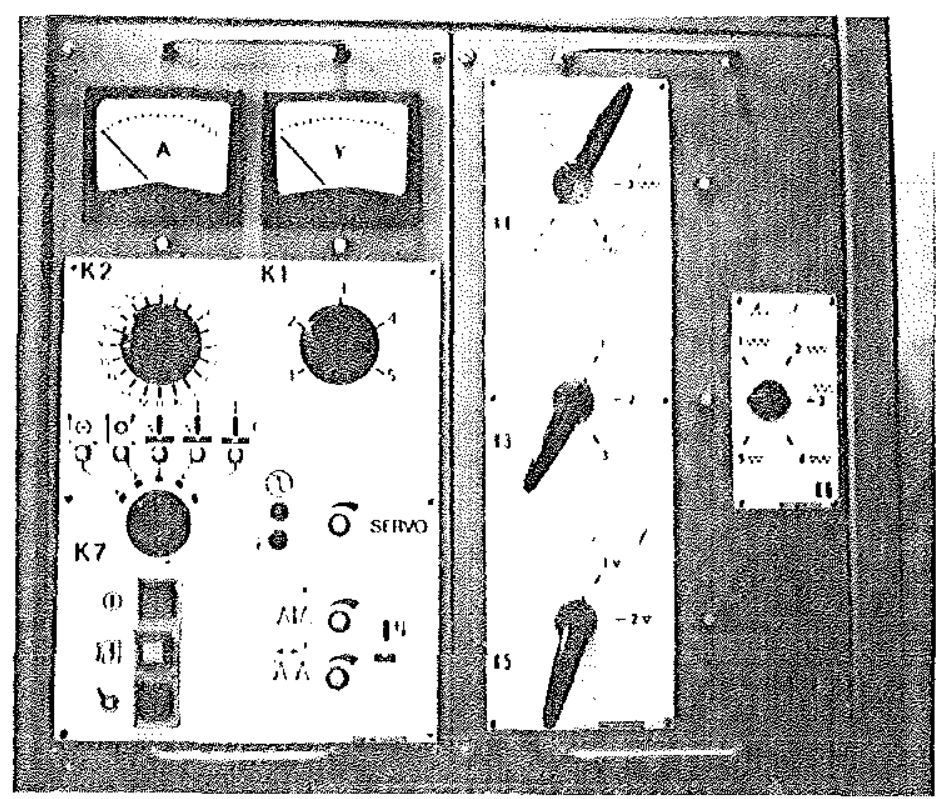

Fig. 40 - Painel de comando dos circuitos de relaxação, situados no gerador elétrico

Uma vez posicionados os elétrodos de serviço, a seleção dos ajustes elétricos é feita em alguns segundos. Apenas a compensação do peso do elétrodo (e da temperatura do óleo do circuito hidráulico de comando e acionamento do cabeçote eletroerosivo), feita por intermédio da alavanca mostrada na Figura 4l, pode levar alguns minutos; é uma tạ refa que exige acuidade e paciência por parte do operador, já que o cabeçote deve ficar parado no meio do curso, ao longo do eixo dos " $z$ ", com os pulsadores de comando "ascen dente" e "descendente" do movimento do cabeçote, soltos.ES sa compensação, quando bem feita, é fundamental para um bom funcionamento do servo-sistema eletro-hidráulico. Isso é necessário porque o peso do elétrodo-ferramenta pode ser de até $200 \mathrm{~N}$. 
$\$$

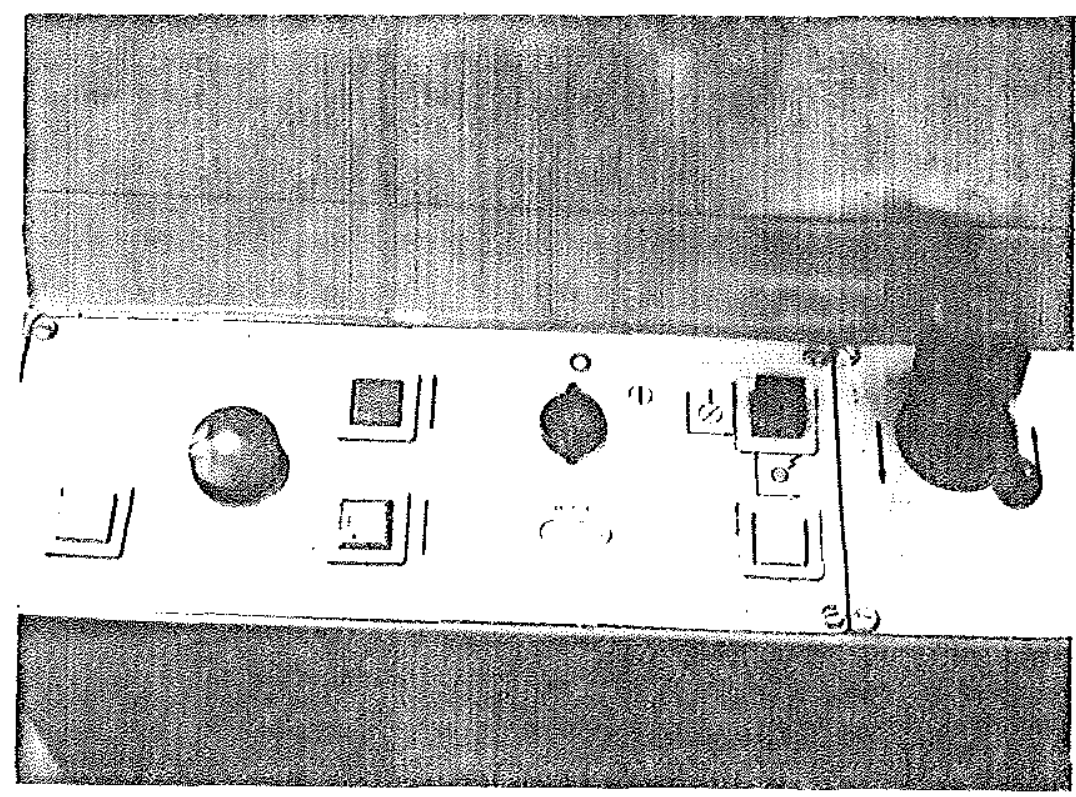

Fig. 41 - Painel de comando do cabeçote, situa do na máquina-ferramenta eletroeros $\bar{i}$ va

o regulador eletro-hidräulico é um dos principais elementos que compõem o servo-sistema de comando do a vanço do cabeçote eletroerosivo (Figura 42-a). Compõe-se de um sistema bico-patheta e um transdutor de indutância di ferencial, apresentado esquematicamente na Figura 42-b. Sua função é manter o "gap" entre os elétrodos durante a usina gem, evitando assim o contato metảico entre eles, com a consequente formação de curto-circuito. Esse sistema alia a rapidez de resposta do transdutor elëtrico ao elevado ga nho do transdutor hidráulico e é larganente utilizado em máquinas e dispositivos que empregam níveis moderados e al tos de energia; seu uso tem sido uma constante na maioria das máquinas UEE em operação, ainda que, sob condições de altas frequências de descarga, esse sistema deixe muito a desejar. 


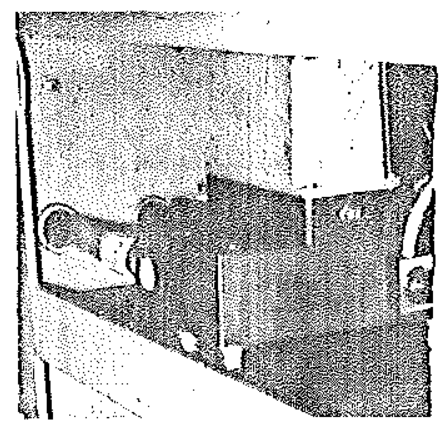

(a)
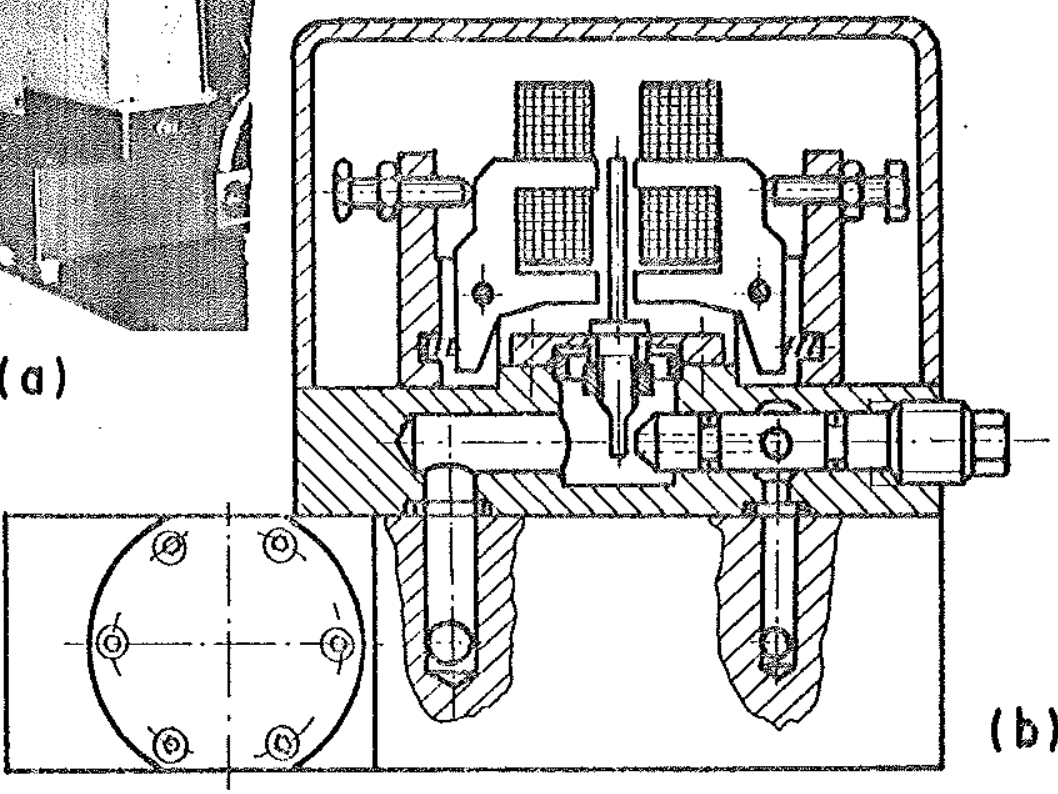

(b)

Fig. 42 - Regulador eletro-hidráulico do avanço do cabeçote eletroerosivo

A unidade de alimentação hidráulica do comando e acionamento do cabeçote é apresentada na Figura 43 . Ela é constituída de um reservatório de óleo, com capacidade de 18 litros, uma bomba acionada a $1.420 \mathrm{rpm}$ por um motor 380 $\mathrm{V}$ e $2,2 \mathrm{Kw}$. O óleo, durante o processo da usinagem, assume uma faixa de tempexatura de serviço de 30 a $60^{\circ} \mathrm{C}$, uma vis cosidade de 20 a 25 cSt a $50{ }^{\circ} \mathrm{C}$. $\Lambda$ pressão de serviço do ó leo, recomendada pelo fabricante, é de $3 \mathrm{MPa}$.

A unidade de bombeamento do fluido dielétrico(F gura 44) é responsável pelo fornecimento desse líquido ao reservatório de serviço a uma vazão de, até, $1,66 \times 10^{-3}$ $\mathrm{m}^{3} / \mathrm{s}(100 \mathrm{l} / \mathrm{min})$. O motor elétrico de acionamento dessa bom ba centrifuga é energizado a $380 \mathrm{~V}, 0,75 \mathrm{Kw}, 2.880 \mathrm{rpm}$. A pressão máxima do fluido bombeado ë de $0,2 \mathrm{MPa}$. 


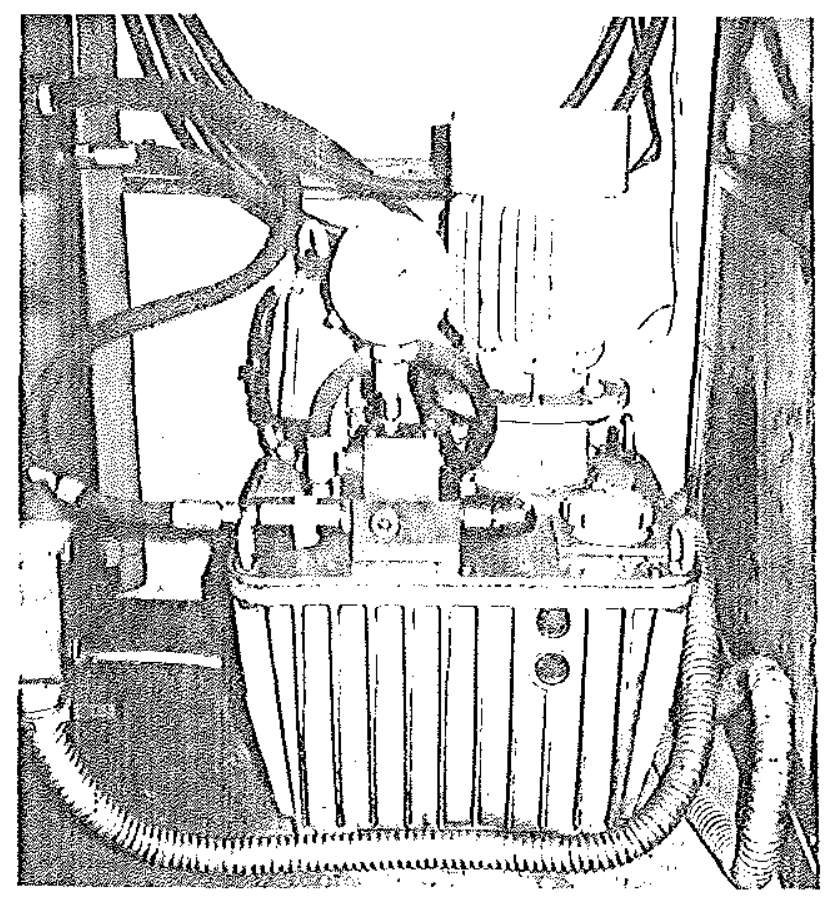

Fig. 43 - Unidade de alimentação hidráulica do cabeçote eletroerosivo

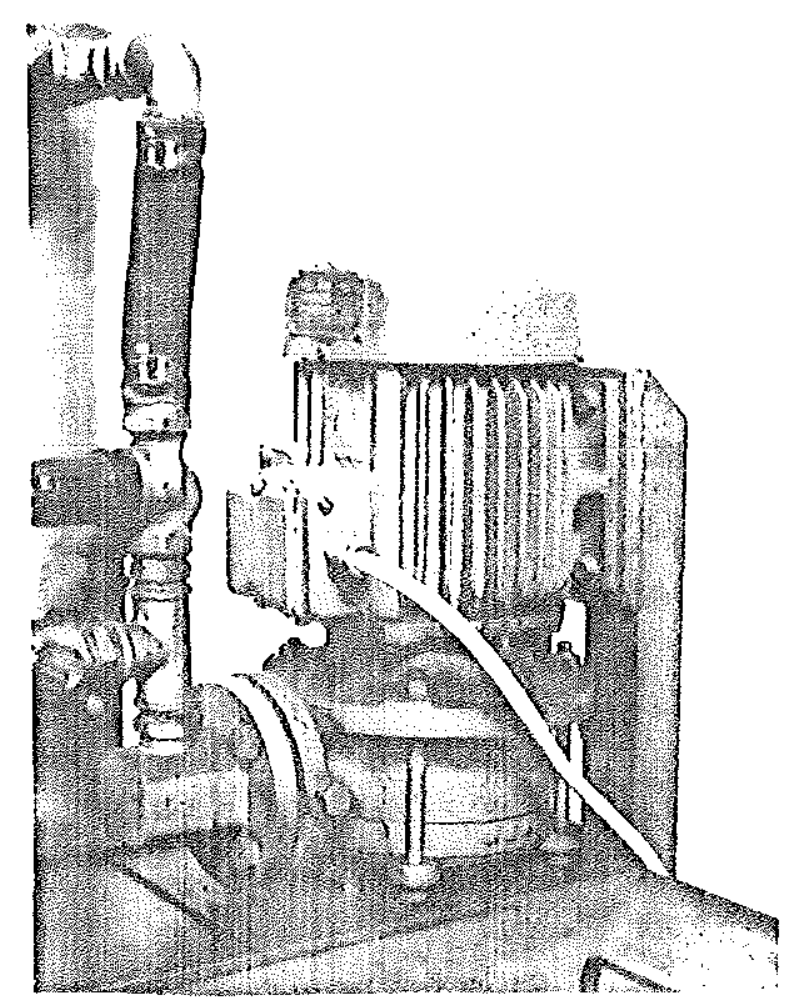

Fig. 44 - Unidade de bombeamento do circuito de di.stribuição do fluido dielétrico 
Em usinagem de desbaste, o rotor da bomba é alta mente solicitado pelo líquido contaminado. Apesar do siste ma de pré-filtragem e decantação reter uma quantidade considerável de particulas metálicas (Figura 45), essas bande jas são impotentes para reter as partículas coloidais, que são aspiradas pela bomba, juntamente com o líquido, e recalcadas para o reservatório de serviço, alterando as condições de usinagem. Saliente-se que, durante o serviço de desbaste, não se utiliza o sistema de filtragem do dielétrico, para evitar danos nos cartuchos tubulares e consequente inutilização dos mesmos.

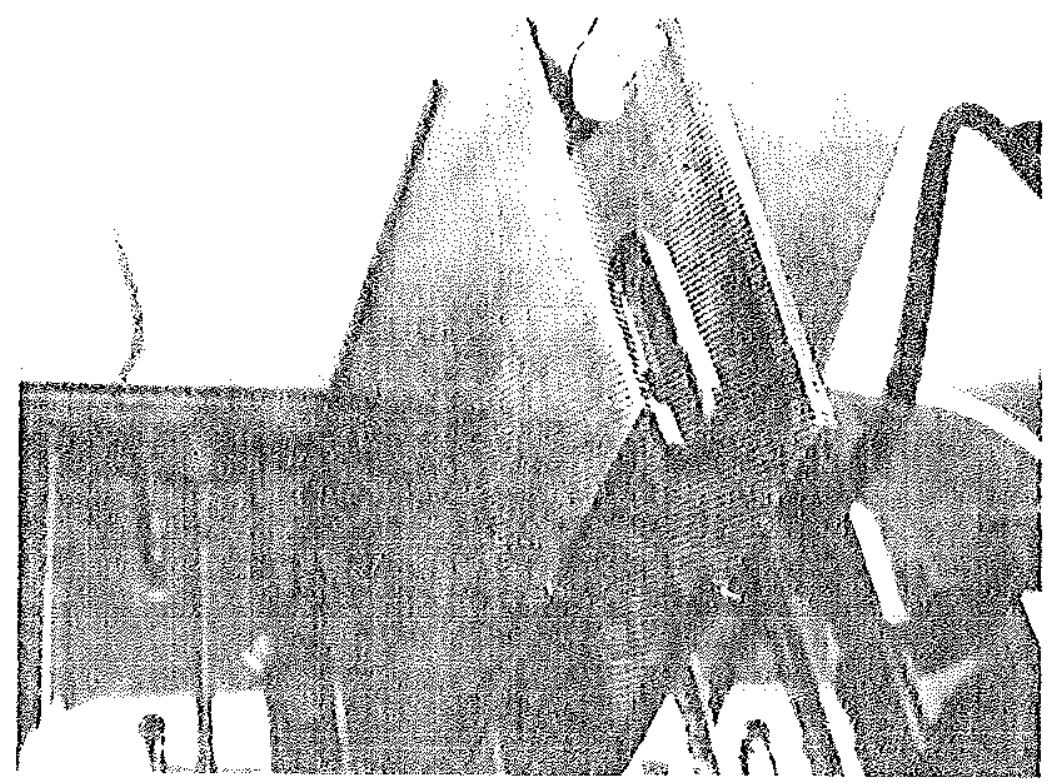

Fig. 45 - Sistema de pré-filtragem e decantação do fluido dielétrico

A unidade de filtragem do fluido dielétrico é mostrada na Figura 46-a. Compõe-se de três filtros, com dois cartuchos tubulares cada um (Figura 46-b). Tais filtros as seguram a retenção de partículas cujas dimensões são superiores a $5 \mu \mathrm{m}$ e a desobstrução dos seus poros deve ser periodicamente providenciada através de imersão em líquido diejêtrico limpo. Essa operação assegura a eficiência do sistema e reduz a queda de pressão do fluido de serviço nessa unidade. 


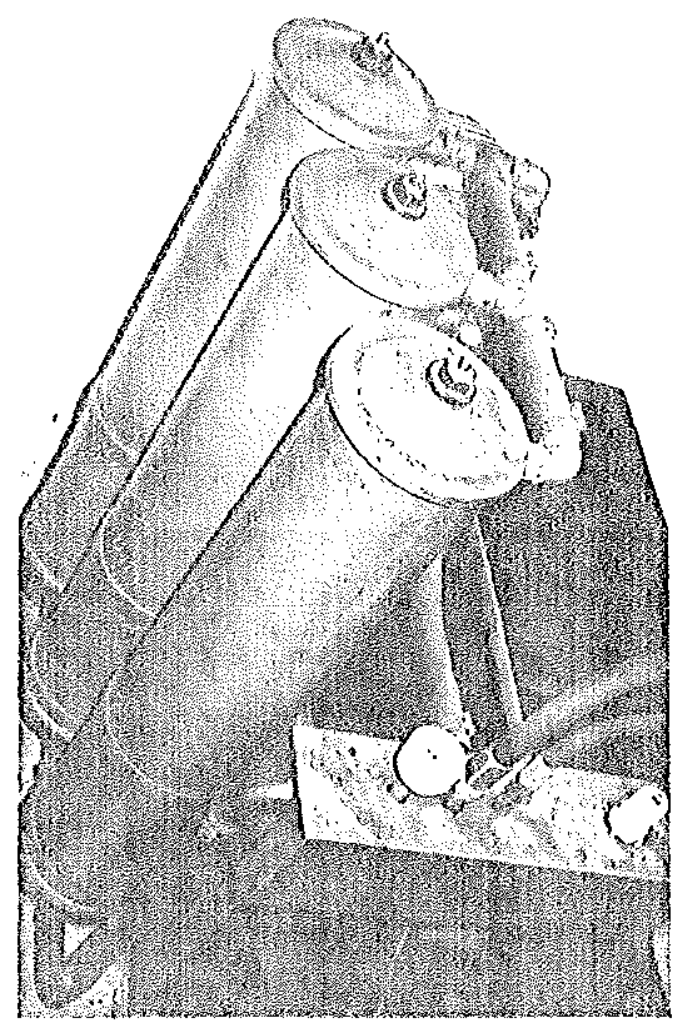

(a)

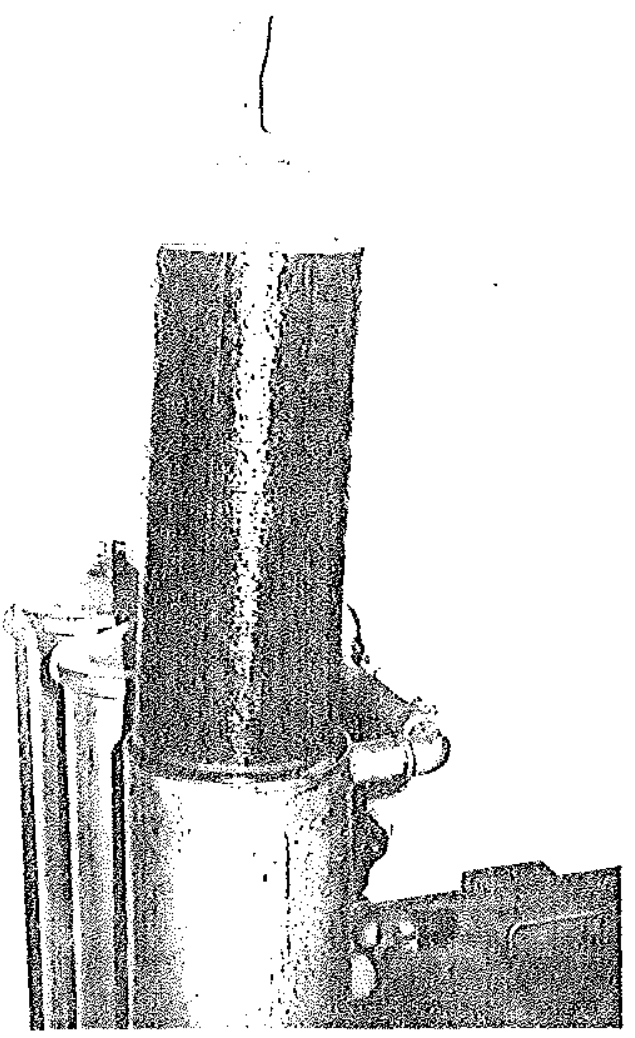

(b)

Fig. 46 - Unidade de filtragem do fluido dielétrico

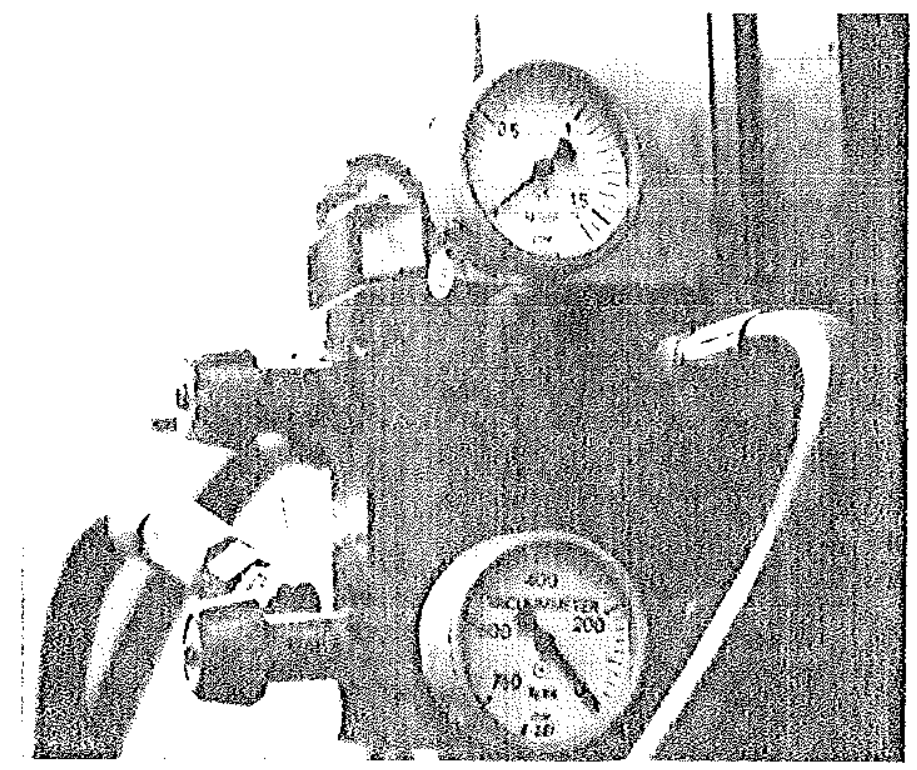

Fig. 47 - Vảlvulas de regulagem manual dos sistemas de lavagem por injeção (acima) e aspiração (abaixo) 
As vâlvulas de regulagem manual de pressão manomêtrica e vacuométrica de lavagen por injeção e aspiração, respectivamente, do fluido dielétrico, são apresentadas na Figura 47. No plano de fundo, si.tua-se a välvula magnética de comando da lavagem pulsante por injeção do dielétrico.

A temperatura do fluido dielétrico no reservatório de serviço é monitorada por um termo-resistor, montado nesse reservatório, acoplado a um termo-interruptor (Figura 48), que protege o equipamento contra possíveis aquecimentos críticos (superiores a $40^{\circ} \mathrm{C}$ ), desconectando automa ticamente a tensão elétrica do gerador necessária à realização da operação de usinagem.

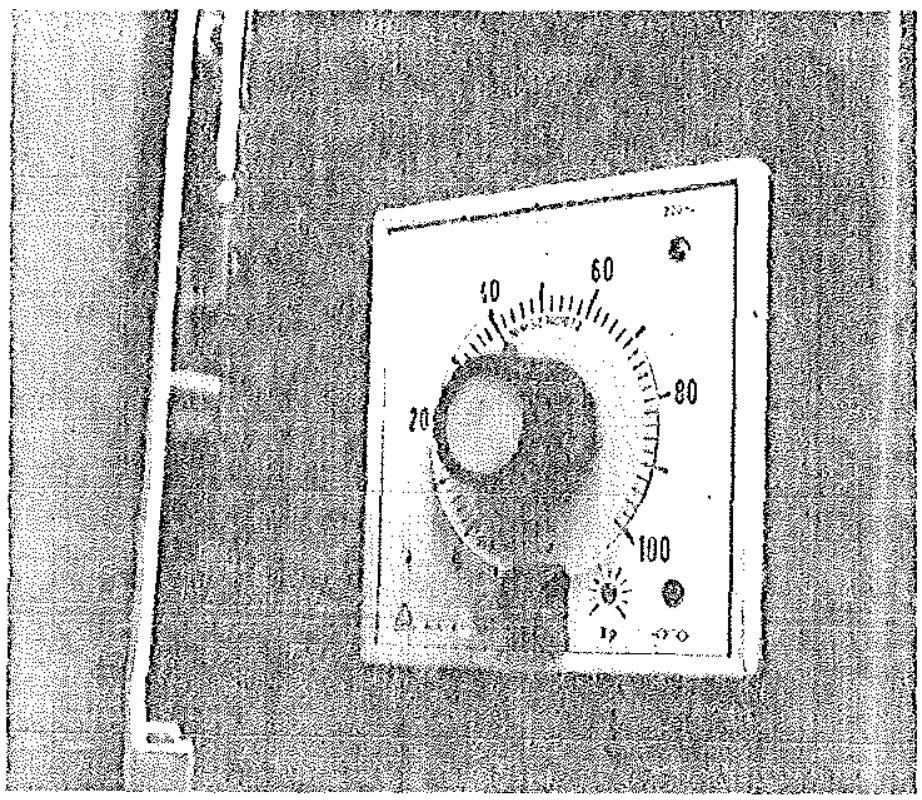

Fig. 48 - Termo-interruptor de proteção contra eventuais superaquecimentos do fluido dielëtrico em servíço

Como se depreende, apesar de possuir um gerador considerado ultrapassado, a mácquina-ferramenta eletroerosi va utilizada apresenta uma boa acuracidade dimensional e segurança de funcionamento, o que é muito importante no pro 
cesso, pelos riscos de vida inerentes à utilização de equi pamentos que trabalham a alta tensão elétrica e lidam, simultaneamente, com líquido inflanável.

A operação do equipamento pode ser feita com mui. ta facilidade, sem a necessidade de um operador de alto grau de especialização. Posta em funcionamento, a máquina opera sozinha até a profundidade de corte predeterminada pe lo limitador automätico de curso, liberando assim o operador para executar outras tarefas.

\subsection{Projeto e Fabricacão dos Elétrodos de Ensaio}

A filosofia do projeto adotada no dimensionamento dos elétrodos a serem empregados nos ensajos assumiu, como premissa, a característica básica de utilização de u’ a mäquina-ferramenta eletroerosiva com gerador do tipo relaxaçäo: prioridade para os ensaios de acabamento.Procurou -se, dessa maneira, determinar um ponto de equilíbrio entre o tempo de operação, a área frontal e o custo do elétrodo-ferramenta.

A área frontal do eletrodo-ferramenta influi decisivamente na velocidade de remoção de material. e no desgaste do elétrodo-ferramenta, conforme jä foi. salientado anteriormente. De acordo com o gráfico da Figura 49, a usi nagem eletroerosiva de uma peça com elétrodo de áxea frontal $\Lambda_{f}=1000 \mathrm{~mm}^{2}$ - o que equivale a uma barra de seção cir cular de diàmetro $35,68 \mathrm{~mm}$ - deve ser efetuada, com o melhor rendimento, a una velocidade de remoção de material. (VRM) de $200 \mathrm{~mm}^{3} / \mathrm{min}$; analogamente, para um elétrodo com $A_{f}=45 \mathrm{~mm}^{2}$, deve sex associada uma $V R M=20 \mathrm{~mm}^{3} / \mathrm{min}$ ipara $A_{E}=7 \mathrm{~mm}^{2}, \mathrm{VRM}=5 \mathrm{~mm}^{3} / \mathrm{min}$.

Sob essa éçìde, foram selecionados os valores apresentados na Tabela 6.1 para as áreas frontais dos elétrodos. Os elëtrodos de seģão vazada tinham um furo de diâa metro $2,38+14 \mathrm{~mm}$. Optou-se pelo uso de elétrodos-ferramen 
ta de seção quadrada, para possibilitar uma análise quali. tativa do axredondamento dos cantos em função da profundidade de penetração desses elétrodos.

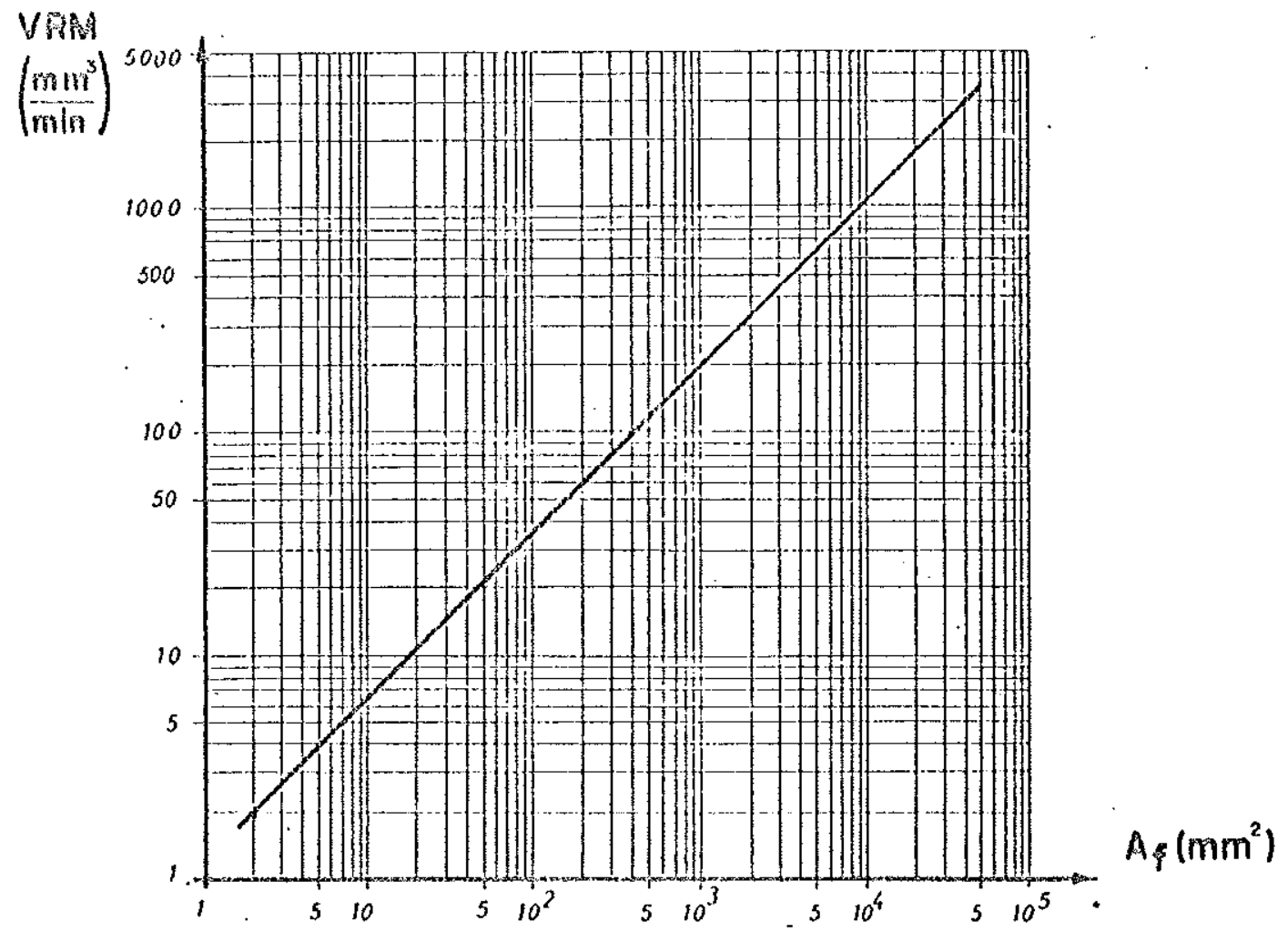

Fig. 49 -. Correlação entre a VRM e a área frontal. ótima do elétrodo ${ }^{23}$

Assim, a determinação daqueles valores de $A_{f}$ pro porcionou una economia significativa no custo dos ensaios, maior acuracidade dos resultados obtidos nos ensaios de acabamento e un tempo total de usinagem relativamente curto.

o material. usado na fabricação dos elétrodos-fer ranentas foi o cobre eletrolítico; o elëtrodo da peça era de aço ABNT 1010, com a segui.nte composição: $0,10 \%$ C ,0,049\% $\mathrm{S}, 0,4 \div \mathrm{Mn}, 0,006$ 응 $\mathrm{e} 0,018$ ․

A fabricação dos elëtrodos-ferramentas foí execu tada utilizando-se os processos convencionais de usinagem. As difficuldades surgidas, nessa etapa, disseram respeito à não-fixação dessess elétrodos na mesa magnética da retifica, face às propriedades diamagnéticas do cobre; tornou-se 
Tab. 6.1 - Características dimensionais dos elëtrodos-ferramentas durante os ensaios

\begin{tabular}{|c|c|c|c|c|c|}
\hline \multicolumn{2}{|c|}{ Seção Frontal } & \multirow{2}{*}{$\begin{array}{l}\text { Diânetro } \\
\text { do furo } \\
\text { central } \\
\text { (mm) }\end{array}$} & \multirow{2}{*}{$\begin{array}{c}\text { Area } \\
\text { Erontal } \\
\left.\text { (mit }^{2}\right)\end{array}$} & \multicolumn{2}{|c|}{ Seções Laterais } \\
\hline $\begin{array}{c}\text { Dimensão } \\
\text { (num) }\end{array}$ & $\begin{array}{c}\text { Toleräncia } \\
\text { dimensional } \\
\text { (um) }\end{array}$ & & & $\begin{array}{c}\text { Comprimento } \\
\text { (mon) }\end{array}$ & $\begin{array}{l}\text { Estado } \\
\text { final }\end{array}$ \\
\hline 6,0 & & 2,38 & 31,55 & & Retificado \\
\hline 6,0 & & - & 36,00 & & Aplainado \\
\hline 6,4 & & 2,38 & $36,5.1$ & & Retifjcado \\
\hline 6,4 & +0 & $\cdots$ & 40,96 & 28 & Aplainado \\
\hline 7,0 & -10 & 2,38 & 44,55 & & Retificado \\
\hline 7,0 & & - & 49,00 & & Aplainado \\
\hline 7,5 & & 2,38 & 51,80 & & Retificado \\
\hline 7,5 & & .- & 56,25 & & Aplainado \\
\hline
\end{tabular}

mister a aduptaçăo de um sistema de fixação dos elétrodos de cobre que possibilitasse a retificação das faces late-rais dos elêtrodos. Isso foi contornado pela execução de dois furos cegos de diâmetro $2,38+14$ mo e profundidade 6,0 mm nas duas superficies frontais dos elétrodos, que per mitiam o acoplamento dos dois dispositivos de aço mostrados na Figura 50. As superfícies frontais dos elétrodos fo ram faceadas e polidas con lixa número 120 , proporcionando - thes uma rugosidade superficial de 1,12 Hm (VDT 21).
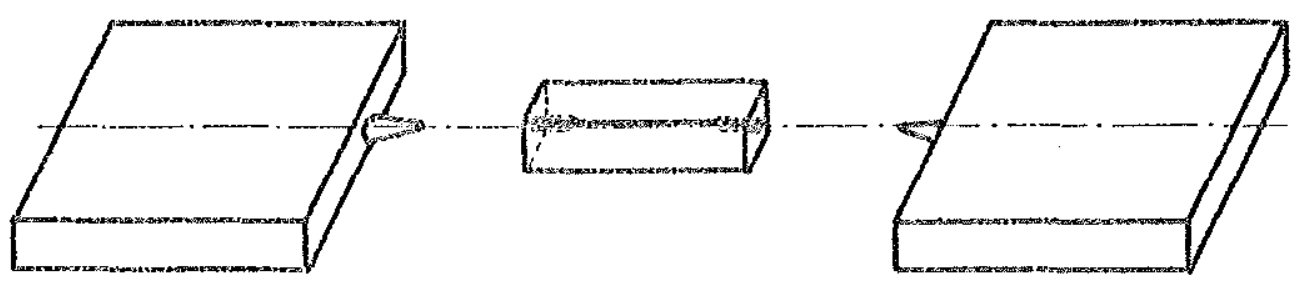

Fig. 50 - Dispositivos usados para a fixação dos elëtrodos-ferramenta na mesa de trabatho da retífica plana 
As peças usinadas de aço-carbono tinham, em mëdia, $170 \times 50 \times 11$ mm e algumas possuíam uma carreira de furos para lavagem, cujo diâmetro era de $2,38+14 \mathrm{~mm}$. Uma parte dos ensaios foi efetuada centrando-se o elétrodo-ferramenta sobre um desses furos e procedendo-se a usinagem; a outra parte consistiu em usinar os furos sem orifício de lavagem (Figura 5.1).
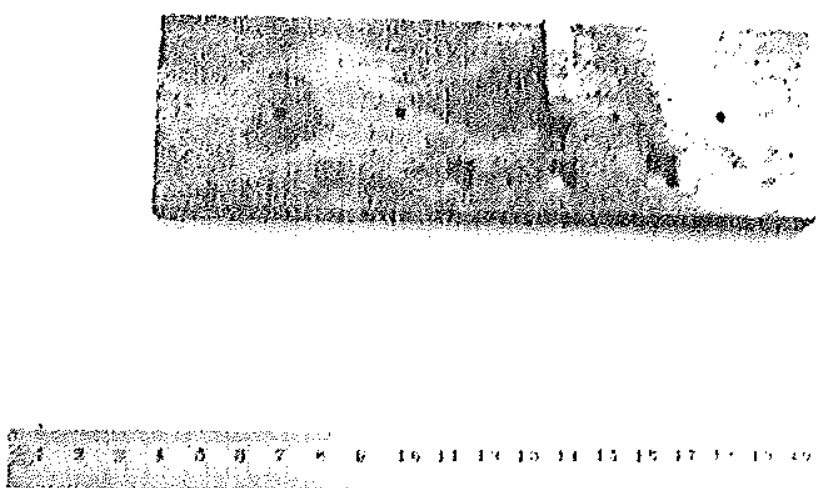

Fi.j. 51 - par de elëtrodos usados en cada ensaio. o elétrodo-ferxamenta (no de referência 28, na figura) era utilizado uma única ver

\subsection{Metodologia}

Uma vez projetados e fabricados os elétrodos e o

dispositivo de fixação do elëtrodo-ferramenta, passou-se à fase seguinte, de realizaçäo dos ensaios.

Inicialmente, os elëtrodos eram convenientemente posicionados com o auxílio de um relógio comparador. Re gistravam-se os valores medidos da temperatura ambiente e umidade relativa do ar. 
A maior parte dos ensaios foi executada empregan do--se lavagem por injeção lateral do fluido dielétrico,por ser a mais facilmente adaptável à maioria das aplicações industriais. Utilizou-se, ainda, lavagem por aspiração do fluido dielëtrico na zona de lavagem.

Nas usinagens que empregaram lavagem por injeção lateral do fluido dielétrico, o tubo de injeção tinha a sua extremidade distando $15 \mathrm{~mm}$ de uma das faces do elétrodo e exa posicionado na direção da zona de usinagem, para ensejar una lavagem eficiente das partículas naquela regi.äo e melhorar, portanto, as condições de usinagem. Duran te os ensaios cuja lavagem era efetuada por aspiração do líquido contaminado na zona de usinagem, empregou-se uma "cânara de lavagem" tipo copo, à qual se acoplava una tubu lação de suç̧ão; essa câmara posicionava-se sob a peça usi nada e as partículas erodjdas dispersas no fluido alojavam -se ali, ou exam aspiradas, juntamente com o líquido, para o tanque de dielétrico.

As leituras da pressão manométrica de injeção e vacuomëtrica de aspiração foram efetuadas nos manônetros e vacuômetros incorporados à máquina-ferramenta eletroerosiva utj.lizada (Fj.gura 47).

Os valores eficazes da tensão elétrica de ajuste e da corrente de descarga foram medidas por meio de um vol tímetro e um amperjmetro, respectivamente, localizados no painel. de comando do gerador elëtrico ( $F j$ gura 40). Essa ten são permaneceu constante em una faixa de $\pm 5 \mathrm{~V}$. A corrente de descarga, por seu turno, permaneceu constante dentro de $\pm 0,1 \mathrm{~A}$, nos ensaios de acabamento, e de $\pm 0,3 \mathrm{~A}$, nós ensaios de desbaste.

A rabela 6.2 apresenta as divexsas variáveis do processo UEE controladas ou monitoradas durante a experimentação, os instrumentos empregados na medição dessas variáveis, seu fabricante, procedência, faixa de leitura e acuracidade de cada um. 
rab. 6.2 - Instrumentação utilizada durante os ensalos

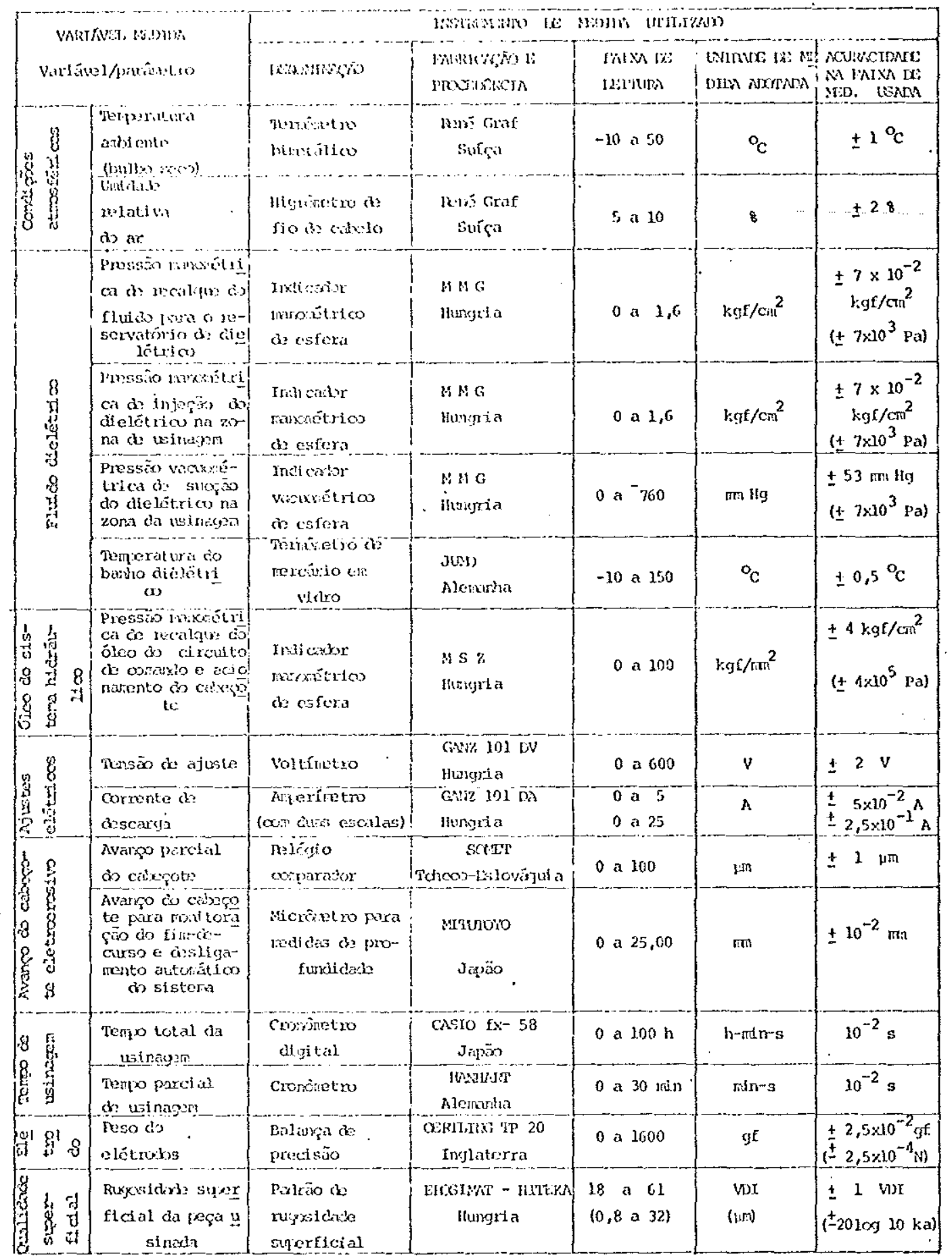


A velocidade de avanço do cabeçote porta-elétrodo Foi determinada segundo o esquema da Figura 52: cronome trou-se o tempo de avanço do cabeçote entre dois ou mais pontos situados ao longo do ei yo dos "z",monitorando-se es se avanço com um relögio comparador micrométrico, solidário ao cabeçote eletroerosivo. Isso foi feito apenas em alguns ensaios, porque exigia a atenção constante de alguém para medir tais grandezas, alën de sex uma tarefa muito exausti va. A cada leitura, o operador sentia "in loco" toda a toxicidade do processo, através da inalaçäo dos gases expeli dos durante a usinagem, com o seu odor peculiar.

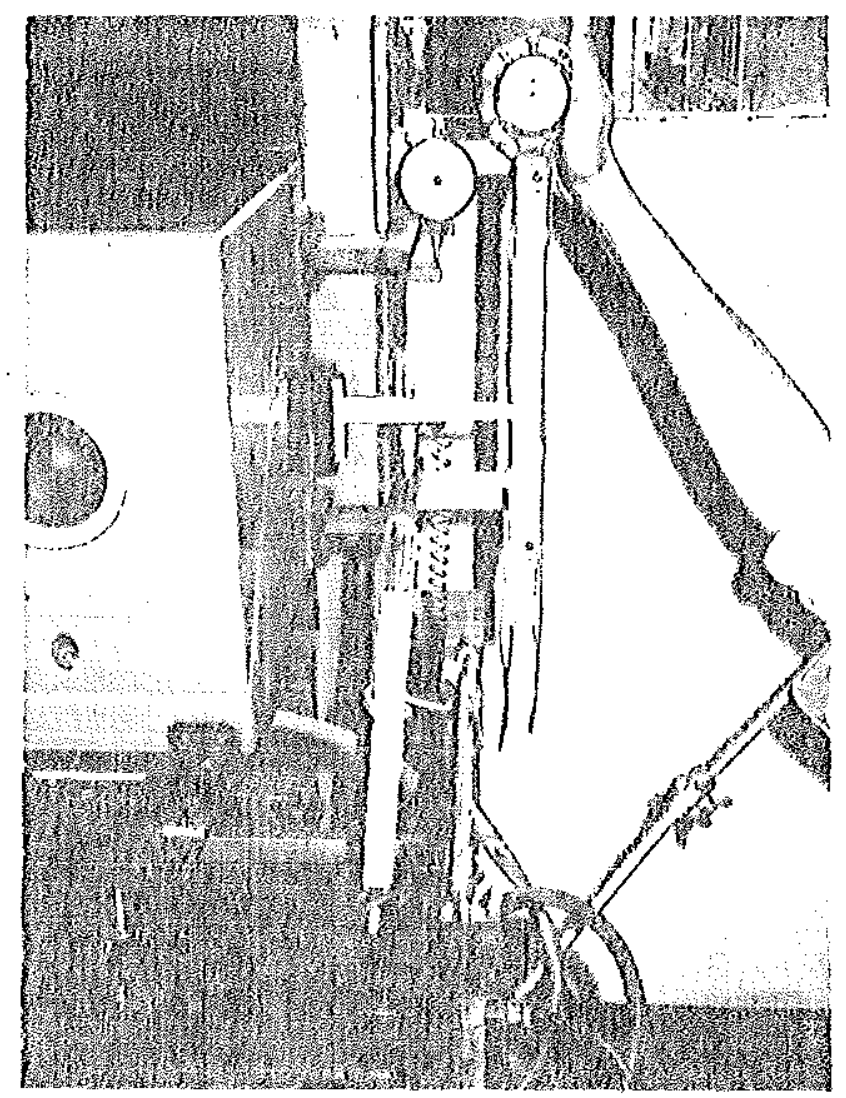

Fi.g. 52 - Método de determinação da velocidade de avanço do elétrodo-ferramenta

A determinaçäo da velocidade de remoção de material. (VRM) foi feita através das medidas do tempo de usina 
gem e do peso do material removido da peça durante a usina gem, segundo a equação 6.1:

$$
V R M=\frac{\Delta \mathrm{P}}{\mathrm{T}_{\mathrm{t}} \mathrm{P}} \cdot \gamma
$$

Analogamente, a relação de desgaste (RD) fol determinada a partix das pesagens do elétrodo-fexramenta e da peça, no início e no fim de cada ensajo, com o auxílio da seguinte equação:

$$
\mathrm{RD}=\frac{\Delta \mathrm{P}_{\mathrm{ef}}}{\Delta \mathrm{P}_{\mathrm{p}}} \cdot \frac{\gamma_{\mathrm{p}}}{\gamma_{\mathrm{ef}}}
$$

ou seja,

$$
R D=\frac{\left(P_{e f}\right)_{i}-\left(P_{e f}\right) f}{\left(P_{p}\right)_{i}-\left(P_{f}\right)_{f}} \cdot \frac{\gamma_{p}}{\gamma_{e f}}
$$

os valores do peso específico dos materiais da peça (aço $A B N T$ 1010) e do elétrodo-ferramente (cobre eletrolítico) são de, respectivamente, $\gamma_{p}=7,8 \mathrm{Kgf} / \mathrm{dm}^{3}(7,651$ $\left.\times 10^{4} \mathrm{~N} / \mathrm{m}^{3}\right)$ e $\gamma_{\text {ef }}=8,9 \mathrm{Kgf} / \mathrm{dm}^{3}\left(8,731 \times 10^{4} \mathrm{~N} / \mathrm{m}^{3}\right)$.

A rugosidade da superfície usinada foi determina da por análise visuall comparativa entre esta e um padrão de rugosidade superficial fornecido pelo fiabricante do equipamento eletroerosivo, auxiliada por uma lupa que arplia $5 x$. O mencionado padrăo foi devidamente afextdo, utilizando-se para isso um rugosinetro de procedencia inglesa, mar ca Surtronic 3, fabricando pela Rank Taylor Hobson, com fai $x a$ de leitura de rugosidade $\mathrm{Ra}=0$ a 25 um e uma acuracida de de $\pm 2 \%$

A escolha do método visual de comparação da rugo sidade superficial da peça usinada e do padrăo apresentado na Figura 53 deveu-se à constatação de que os parâmetros tecnológicos influem muito na qualidade final da superfi... cie usinada e, dessa forma, a acuracidade da leitura obti-da por esse mëtodo ( 1,5 VDI) coaduna-se com a acuracidade aa superfície obtida (ㄴ 3,0 VDI) em função dos parâme- 
tros selecionados, sejam elëtricos, hidrodinâmicos, geomëtricos etc.

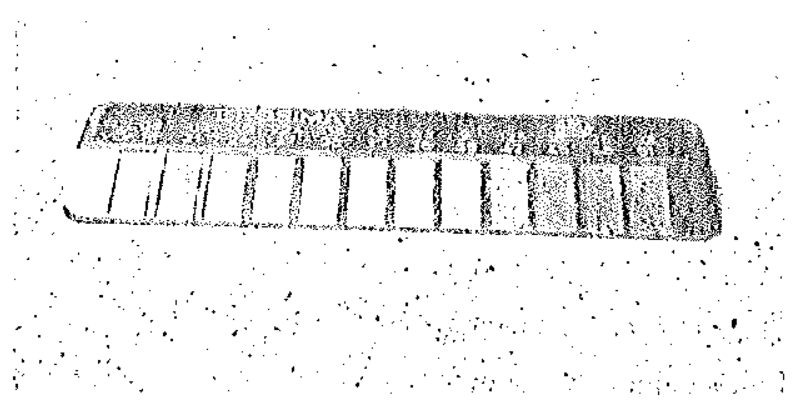
Fig. 53 ... Padrão de rugosidade superficial fornecido pelo fabricante do e- quipamento UEE empregado

Alëm disso, procuroumse, nesse trabalho, reproduzix todos os procedimentos experimentais utilizados em condiçöes operacionais na indústria, para uma maior aplica bilidade dessa pesquisa.

A conicidade de cada furo foi determinada com o auxílio de urn paquímetro. Traçaram-se, em cada uma das qua tro faces da ferramenta, duas linhas de referência, equidistantes 4,0 mu, uma da outra, e 23,0 mm da superfície frontal näo-usinada, no sentido longitudinal do elëtro do; nesses locais, mediram-se as espessuras do elétrodo- ferramenta e determinou-se um par de valores para a coni-cidade de cada furo $(\theta)$, em graus, determinando-se a média. Não houve variações significativas entre as duas coni cidades, nem tampouco entre a conicidade do elétrodo-ferra menta e a da peça usinada. A conicidade foi calculada segundo a expressäo 6.4 :

$$
\theta=\operatorname{arctg} \frac{\left(e_{1}-e_{2}\right) / 2}{\Delta \lambda}
$$

utilizando-se $\Delta l=4,0 \mathrm{~mm}$. I Figura 54 explicita cada uma das variâveis da equação 6.4, enquanto a Figura 55 apresen ta um conjunto de elétrodos com diferentes conicidades e desgaste. A nuneração dos elëtrodos serviu para identi ficá - los nas medidas finais. 


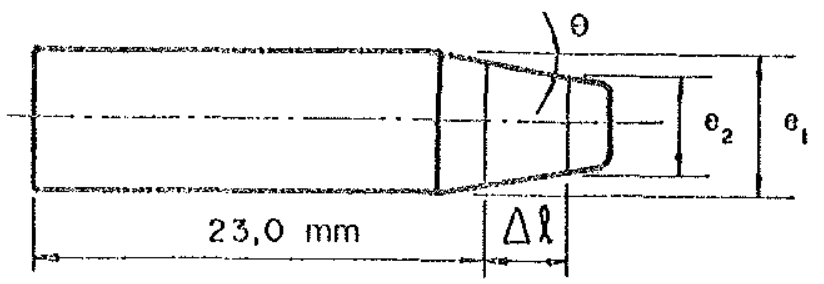

Fig. 54 - Dimensões do elétrodo-ferramenta empregadas no cálculo da conicidade do furo usinado na peça

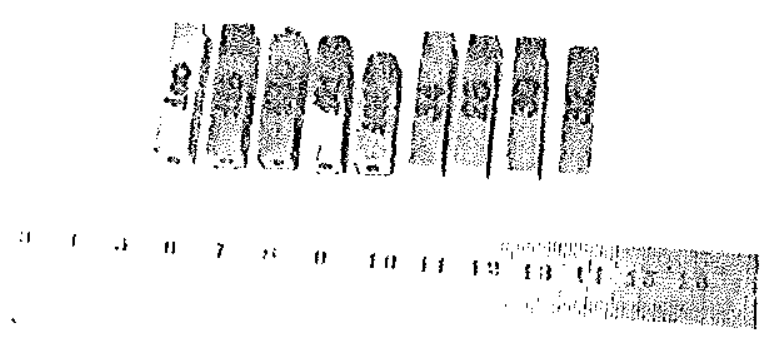

Fig. 55 - Elétrodos utilizados nos diversos regimes de ensajo

o sobrecorte foj determinado pela diferença entre as dimensões do furo executado, à altura da superfície mais externa desse furo, e as dimensões do elétrodo-ferramenta, medida antes do ensaio, diferença essa dividida por: dois. Os valores tabelados são uma mëdia de cada par de va lores medidos, para um mesmo ensaio; não se registrarar vă rlaçöes substanciais entre os dois sobrecortes lidos para thi mesmo ensaio. 


\subsection{Resultados e Discussões}

Apresentan-se, a seguir, os resultados obtidos a través da realizą̧ão dos ensaios. As Figuras 56 a 75 trazem, em forma de gráficos, os valores da relação de desgas te, velocidade de remoção de material, sobrecorte e rugosi dade superficial em função da corrente de descarga.Cada um desses gräficos encexra um conjunto de variäveis que influem no desempenho do processo, como já foi discutido anteriormente; assim, apresentam-se, sob a forma tabular, to das as condições impostas e/ou obtidas em cada ensaio (Tabe 1 a 6.3$)$.

As figuras 56 a 59 dizem respeito ao regime de desbaste da mäquina UEE uti.lizada. Como fora previsto na fase de projeto dos elétrodos-ferramenta, a partir de um determinado nível de corrente de descarga, o que equivale dizer, a partir de um certo nível de energia, o rendimento da usinagem (enexgi a fornecida/energia utilizada na erosão da peça) cai abruptamente, para uma mesma área frontal des se elëtrodo. No caso em anâli.se, para as condições utilizą das, a partir de una intensidade de corrente igual a $5 \mathrm{~A}$ observou-se uma elevada instabilidade operacional do cabȩ̧ote, acompanhada por um aumento apreciável do nível de ru ído do processo.

Esse estágio pode ser visualizado pela sensível redução e aleatoriedade dos valores da velocidade de remoção de matejial, a partix de $5 \mathrm{~A}$. Poder-se-ia dizer que o processo atingiu un estágio de "saturação enexgética" para as condições de usinagem selecionadas.

Fazendo uma analogia com a irrigação de um solo, aquele fenômeno pode ser comparado ao caso em que, atingido o teor ótimo de água nesse solo, continua-se a injetar mais e mais ägua, atë encharcá-lo completamente; por outro lado, uma vez determinada a área a ser irrigada e conhecen do-se a qualidade do solo e o sistema radicular a ele vin- 


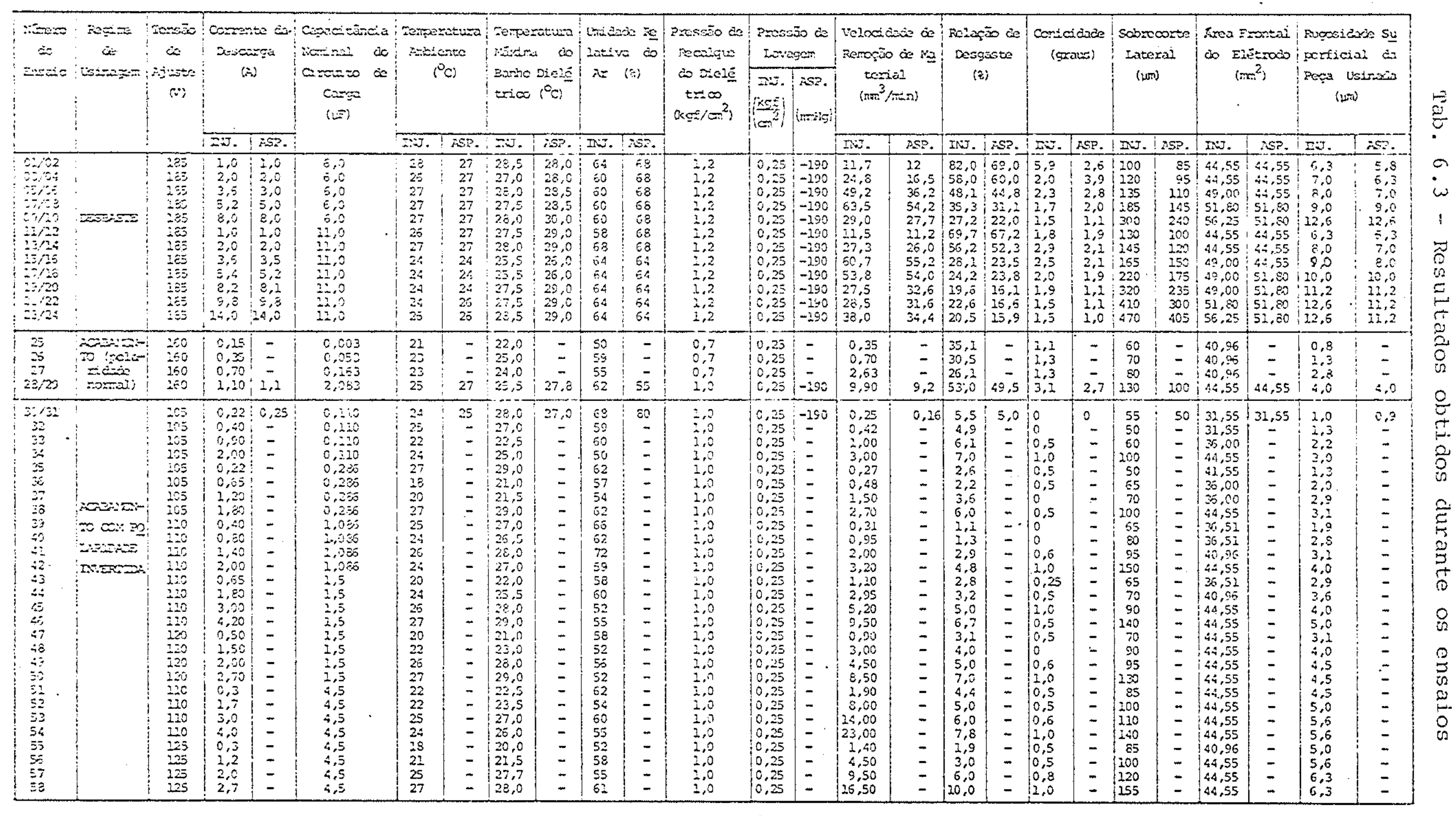


culado, alëm da umidade ótima para a aplicação, pode-se di mensionar o sistema de irrigação conveniente, caracterizado por uma vazão de água determinada, urna frequência de mo Jhamento correspondente etc.

Transpondo-se isso para a UEE, verifica-se que a área a ser usinada é um parâmetro de peso na determinação das condições de usinagem e dos níveis de energia fornecidos por cada descarga, bem como na frequência de descargas.

A I'abela 6.4 apresenta uma correlação entre esses parâmetros hidräulicos e alguns parânetros tecnológi-cos do processo eletroerosivo, a título de ilustração. Características peculiares de cada processo à parte, vê-se que a familiaridade com essa analogia pode ser útil e levar a resultados de interesse às duas äreas.

Tab. 6.4 - Analogia entre alguns parâmetros de irrigação de un solo e da UEE

\begin{tabular}{|c|c|}
\hline PARÂMETROS IRRIGAÇÄO & PARAMETROS UEE \\
\hline Area a ser inrigada & Area a ser usinada \\
\hline Permeabilidade do solo & $\begin{array}{l}\text { Granulometria do material u- } \\
\text { sinado }\end{array}$ \\
\hline Vazão de ägua & $\begin{array}{l}\text { Energia de descarga, no tem- } \\
\text { po }\end{array}$ \\
\hline Frequência de molhamento & Frequência de Descargas \\
\hline $\begin{array}{l}\text { Velocidade de penetração } \\
\text { da água no solo }\end{array}$ & $\begin{array}{l}\text { Velocidade de avanço do cabe } \\
\text { cote }\end{array}$ \\
\hline $\begin{array}{l}\text { Perdas por evapotranspira- } \\
\text { ६ăo }\end{array}$ & $\begin{array}{l}\text { Perdas por aque cimento dos e } \\
\text { lëtrodos, do dielétrico, e- } \\
\text { missão de luz, ruído etc. }\end{array}$ \\
\hline Perdas de carga & $\begin{array}{l}\text { Perdas dielétricas do proces } \\
\text { so }\end{array}$ \\
\hline Sistema radicular: & $\begin{array}{l}\text { Estrutura cristalina do mate } \\
\text { rial usinado }\end{array}$ \\
\hline
\end{tabular}


Regime de usinagem: DESBASTE

polaridade do elëtrodo-ferramenta: negativa

Condições de ensaio: $A_{f}=44,55 \mathrm{~mm}^{2}$

$$
\begin{aligned}
& 49,00 \mathrm{~mm}^{2} \\
& 51,80 \mathrm{~mm}^{2} \\
& 56,25 \mathrm{~mm}^{2}
\end{aligned}
$$

Dielëtrico: querosene

Injeção ou sucção: $2,5 \times 10^{4} \mathrm{~Pa}\left(0,25 \mathrm{Kgf} / \mathrm{cm}^{2}\right)$

Tensão de ajuste: $185 \mathrm{~V}$

Capacitâncja do circuito de carga: $6 \mu \mathrm{F}$

ตอ

(6)
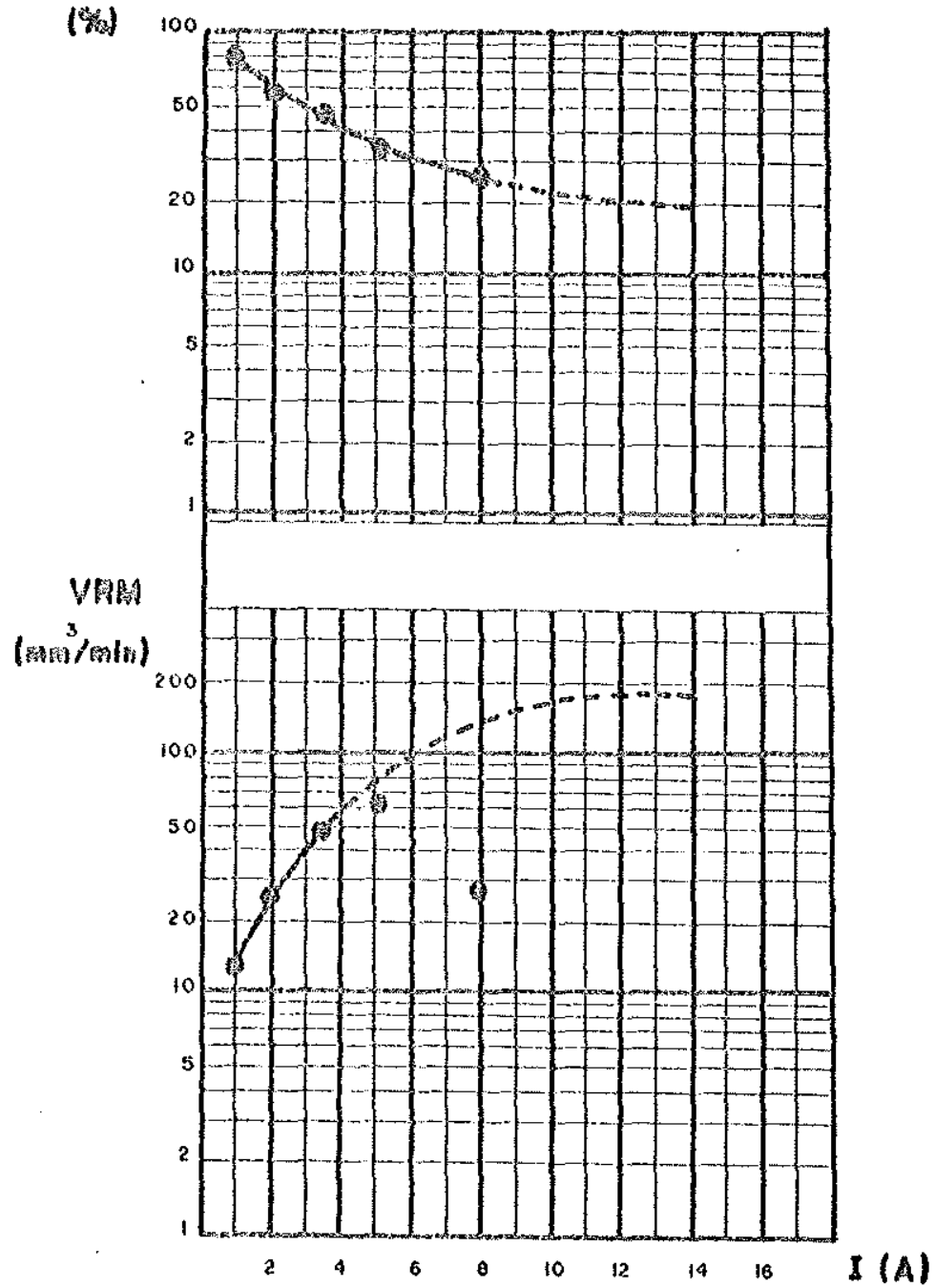

Fig. 56 -' Relaçäo de desgaste e velocidade de remoção de material. em função da corrente de descarga 
Regime de usinagen: DESBASTE

Polaridade do elétrodo-ferramenta: negativa

Condições de ensaio: $\lambda_{f}=44,55 \mathrm{~mm}^{2}$

$49,00 \mathrm{~mm}^{2}$

$51,80 \mathrm{~mm}^{2}$

$56,25 \mathrm{~mm}^{2}$

Dielëtrico: querosene

Injeção ou sução: $2,5 \times 10^{4} \mathrm{~Pa}\left(0,25 \mathrm{kgf} / \mathrm{cm}^{2}\right)$

I'ensăo de ajuste: $185 \mathrm{~V}$

Capacitância do circuito de carga: $6 \mu \mathrm{F}$

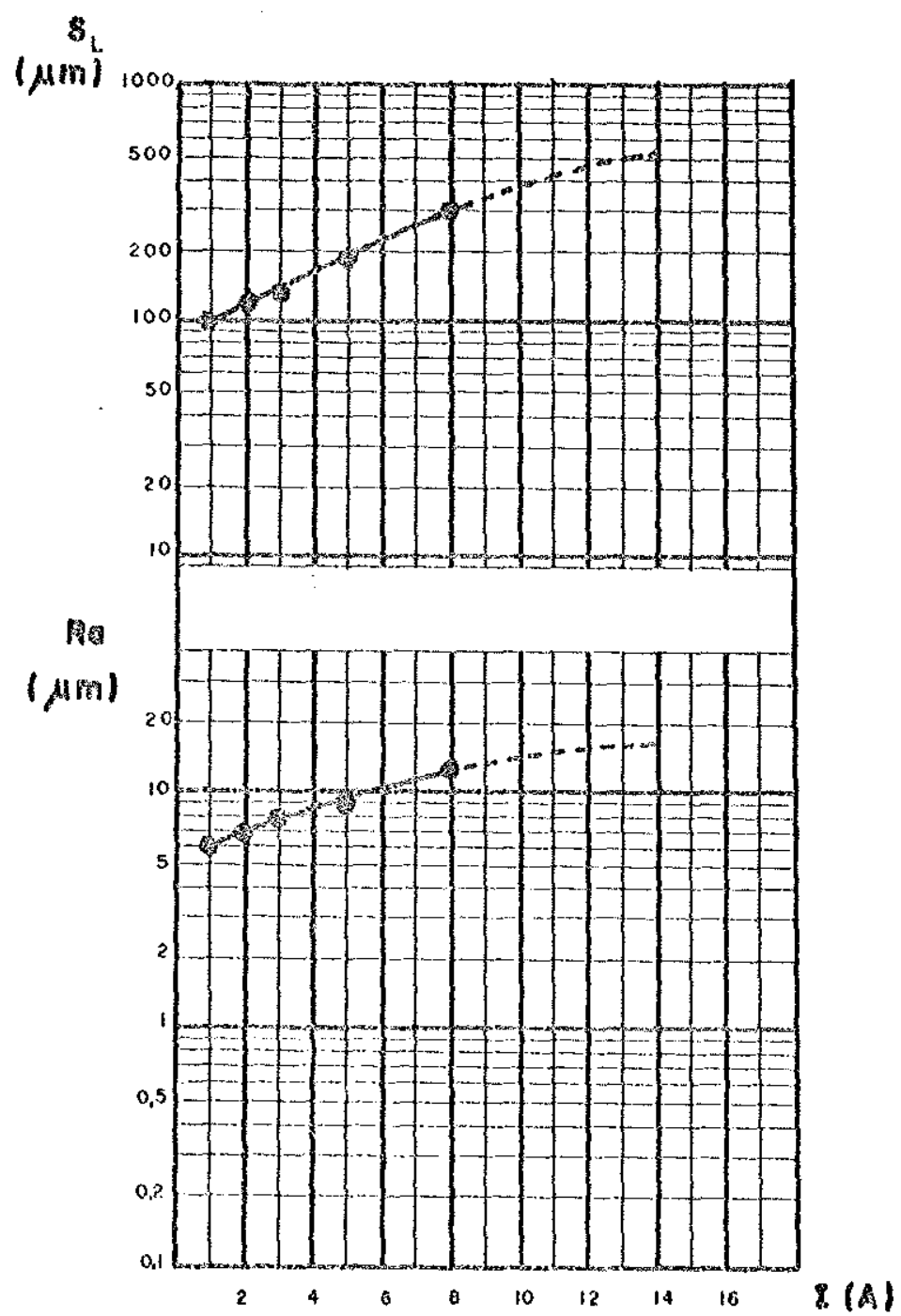

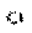

Fig. 57 - Sobrecorte lateral e rugosidade superficial da pela usinada em função da corrente de descarga 
Regime de usinagem: DESBASTE

Polaridacle do elétrodo-ferramenta: negativa

condiçöess de ensaio: $A_{f}=44,55 \mathrm{~mm}^{2}$

$$
\begin{aligned}
& =49,00 \mathrm{~mm}^{2} \\
& =51,80 \mathrm{~mm}^{2} \\
& =56,25 \mathrm{~mm}^{2}
\end{aligned}
$$

Dielëtrico: querosene Injeção ou sucção: $2,5 \times 1.0^{4} \mathrm{~Pa}\left(0,25 \mathrm{Kgf} / \mathrm{cm}^{2}\right)$ Tensão de ajuste: $185 \mathrm{~V}$ Capacitância do cixcuito de carga: $11 \mu \mathrm{F}$

ตD

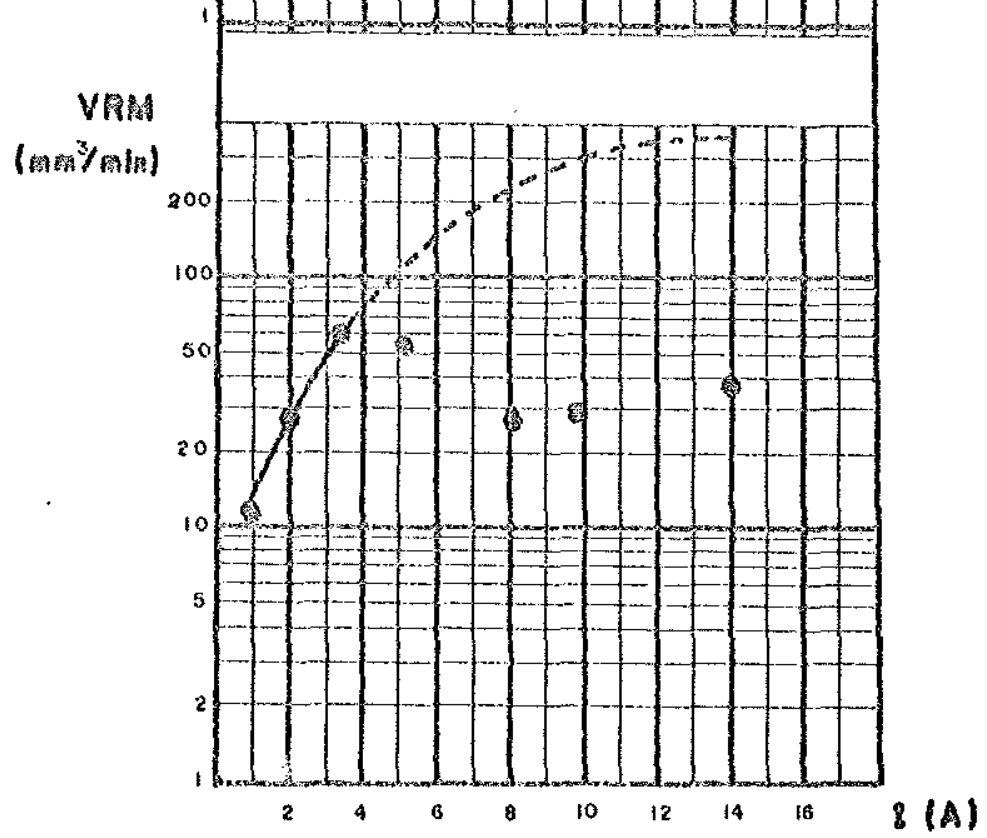

Fig. 58 - Relação de desgaste e velocidade de remoção de material em Eunção da corrente de descarga 
Regime de usinagem: DESBASTE

polaridade do elëtrodo-ferramenta: negativa

Condiçöes de ensaio: $\begin{array}{r}A_{\mathrm{F}}= \\ 44,55 \cdot \mathrm{mm}^{2} \\ 49,00 \mathrm{~mm}^{2}\end{array}$

$51,80 \mathrm{~mm}^{2}$

$56,25 \mathrm{~mm}^{2}$

Dielëtrico: querosene

Injeção ou suç̧ão: $2,5 \times 10^{4} \mathrm{~Pa}\left(0,25 \mathrm{Kgf} / \mathrm{cm}^{2}\right)$

Tensão de ajuste: $185 \mathrm{~V}$

Capacitância do circuito de carga: $1 . \mathrm{L} \mu \mathrm{F}$

$\mathbf{8}_{1}$

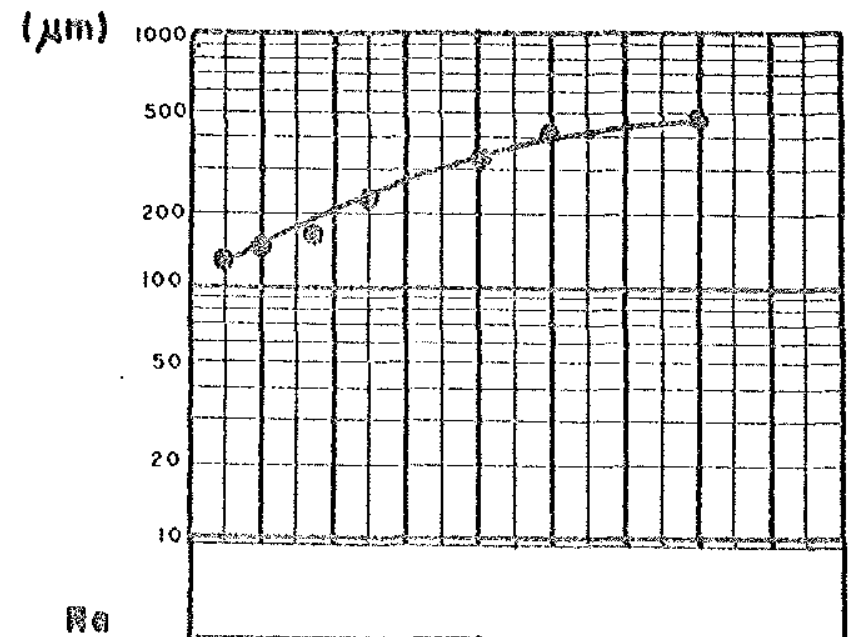

$a$

(

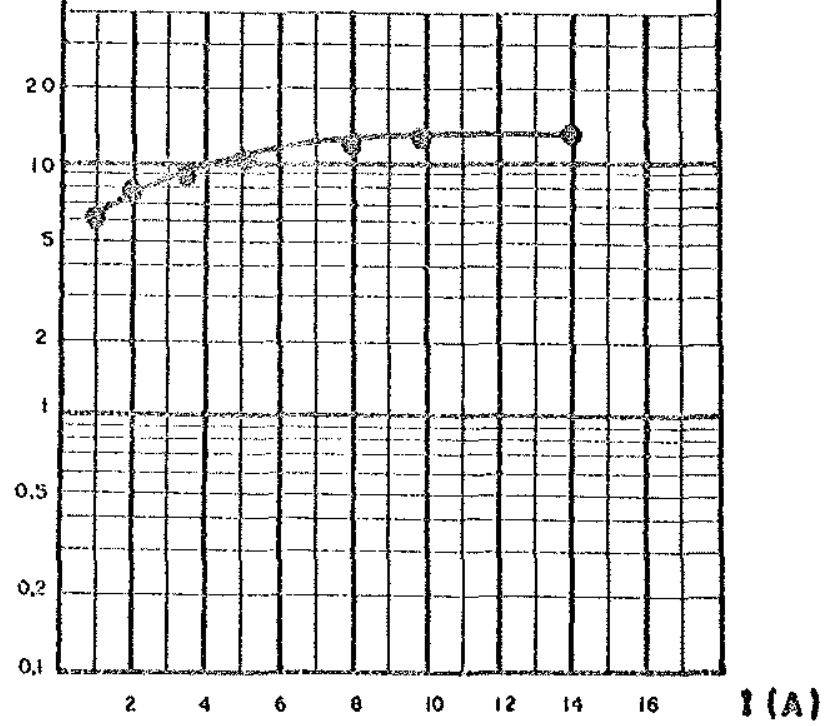

Fig. 59 - Sobrecorte lateral e rugosidade superficial da peça usinada em função da corrente de descarga 
Regime de usinagem: ACABAMENTO

Polaridade do elëtrodo-ferramenta: negativa

Condiçöes de ensaio: $A_{f}=\begin{array}{r}40,96 \mathrm{~mm}^{2} \\ 44,55 \mathrm{~mm}^{2}\end{array}$

Dielëtrico: querosene

Injeção ou sucção: $2,5 \times 10^{4} \mathrm{~Pa}\left(0,25 \mathrm{kgf} / \mathrm{cm}^{2}\right)$

Tensão de ajuste: $160 \mathrm{~V}$

Capacitância do circuito de carga: 3 a $2.083 \mathrm{nF}$

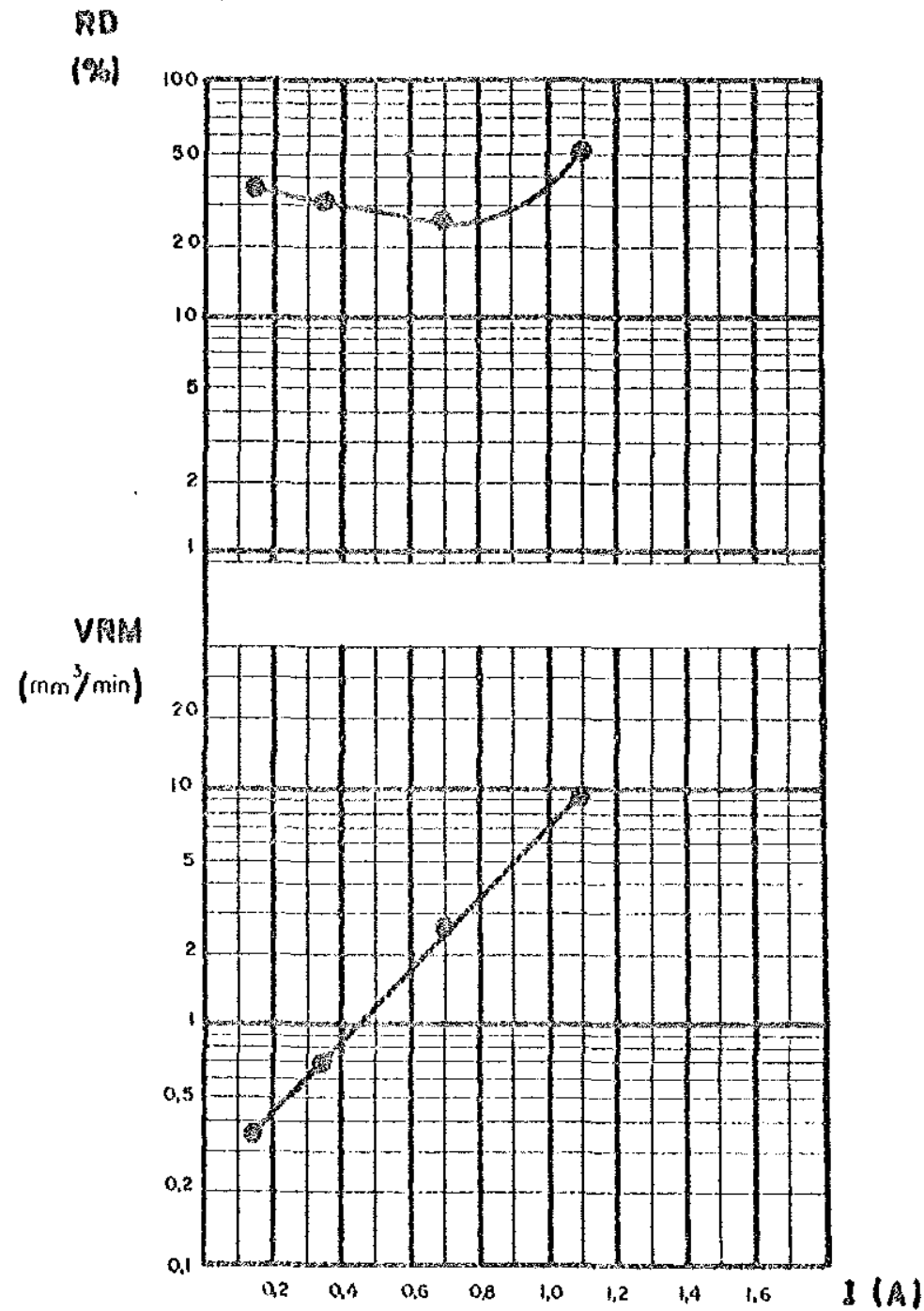

Fig. 60 -- Relação de desgaste e velocidade de remoção de material em função da corrente de descarga 
Regime de usinagem: ACABANENTO

Polaridade do elétrodo-ferramenta: negativa Condições de ensaio: $A_{f}=\begin{array}{r}40,96 \mathrm{~mm}^{2} \\ 44,55 \mathrm{~mm}^{2}\end{array}$

Djelëtrico: que rosene

Injeçäo ou sucção: $2,5 \times 10^{4} \mathrm{~Pa}\left(0,25 \mathrm{kgf} / \mathrm{cm}^{2}\right)$

I'ensão de ajuste: $1.60 \mathrm{~V}$

Capacitancia do circuito de carga: 3 a $2.083 \mathrm{nF}$

1

8

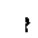

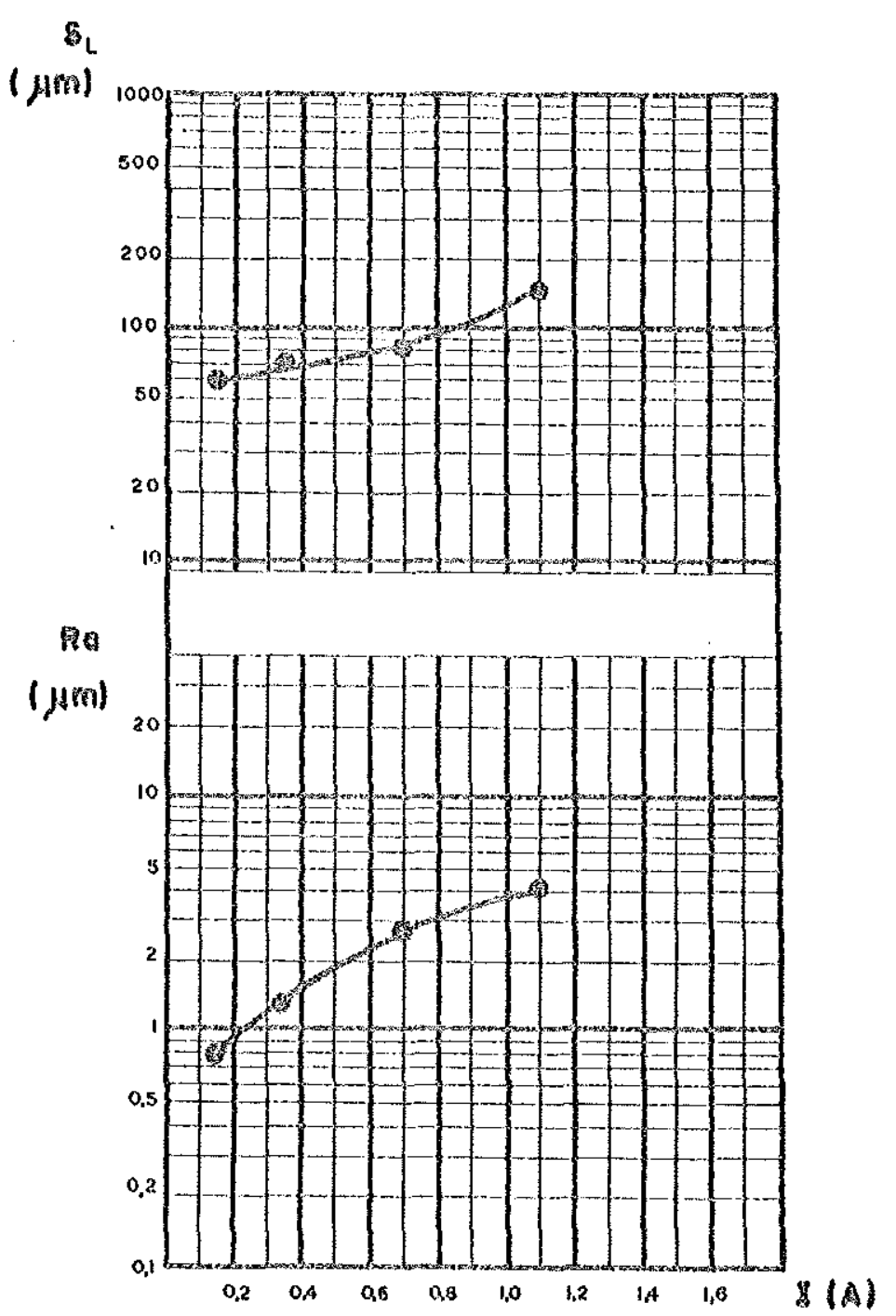

Fig. 61 - Sobrecorte lateral e rugosidade superficial da peça usinada em função da corrente de descarga 
Regime de usinagem: ACABANENTO

polaridade do elétrodo-ferramenta: positiva

Condições de ensajo: $\begin{aligned} A_{f}= & 31,55 \mathrm{~mm}^{2} \\ & 36,00 \mathrm{~mm}^{2}\end{aligned}$

$$
\begin{aligned}
& 36,00 \mathrm{~mm}^{2} \\
& 44,55 \mathrm{~mm}^{2}
\end{aligned}
$$

Dielétrico: querosene

Injeção ou sucção: $2,5 \times 10^{4}$ Pa $\left(0,25 \mathrm{Kgf} / \mathrm{cm}^{2}\right)$

Tensão de ajuste: $105 \mathrm{~V}$

Capacitância do circuito de carga: $110 \mathrm{nF}$

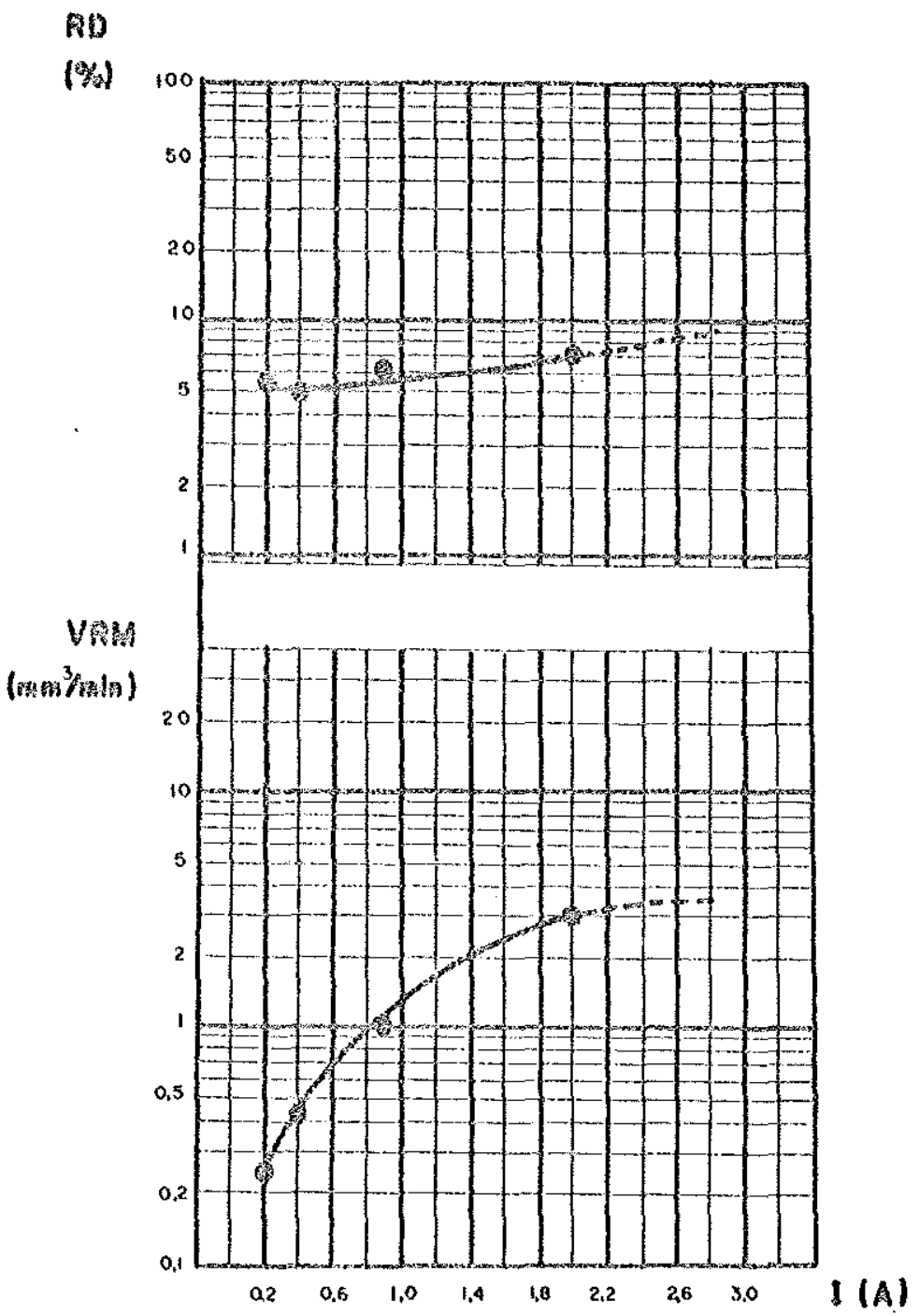

Fig. 62 -. Relação de desgaste e velocidade de remoção de materíal em funçăo da corrente de descarga 
Regime de usinagen: ACABAMENTO

Polaridade do elëtrodo-ferramenta: positiva

Condiçöes de ensaio: $A_{E}=31,55 \mathrm{~mm}^{2}$ $36,00 \mathrm{~mm}^{2}$

$44,55 \mathrm{~mm}^{2}$

Di.elëtrico: querosene

Injeção ou sucçäo: $2,5 \times 10^{4} \mathrm{~Pa}\left(0,25 \mathrm{kgf} / \mathrm{cm}^{2}\right)$

Tensão de ajuste: $105 \mathrm{~V}$

Capacitância do circuito de carga: $c=110 \mathrm{nF}$

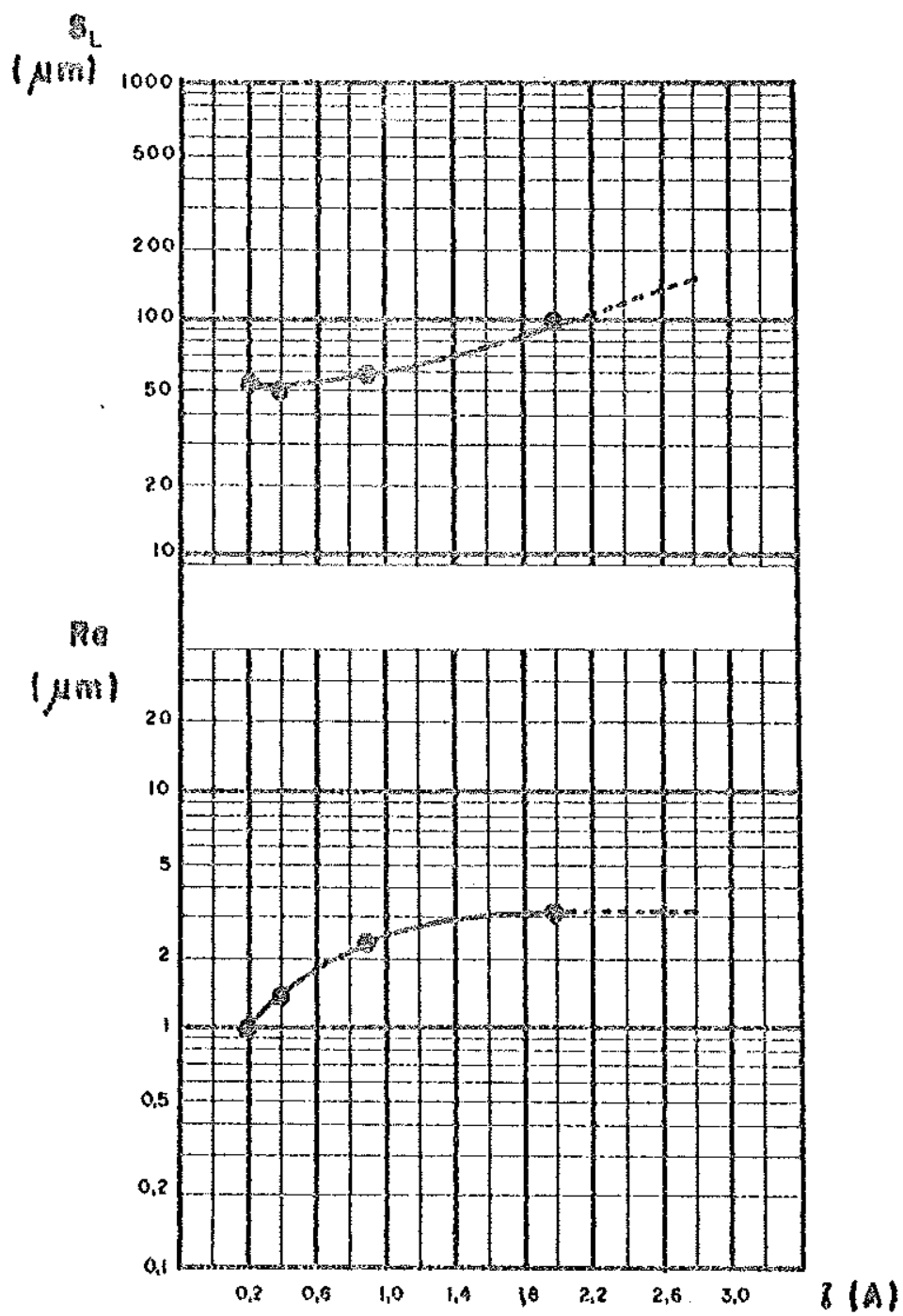

Fly. 63 - Sobrecorte lateral e rugosidade superficial da peça usinada em Eunçäo da corrente de descarga 
Regime de usinagem: ACABAMENTO

Polaridade do elétrodo-ferramenta: positiva

$$
\text { Condições de ensaio: } \begin{aligned}
A_{f}= & 31,55 \mathrm{~mm}^{2} \\
& 36,00 \mathrm{~mm}^{2} \\
& 44,55 \mathrm{~mm}^{2}
\end{aligned}
$$

Dielëtrico: querosene

Injeção ou sucção: $2,5 \times 10^{4} \mathrm{~Pa}\left(0,25 \mathrm{kgf} / \mathrm{cm}^{2}\right)$

Tensão de ajuste: $105 \mathrm{~V}$

Capacitância do circuito de carga: $c=286 \mathrm{nF}$

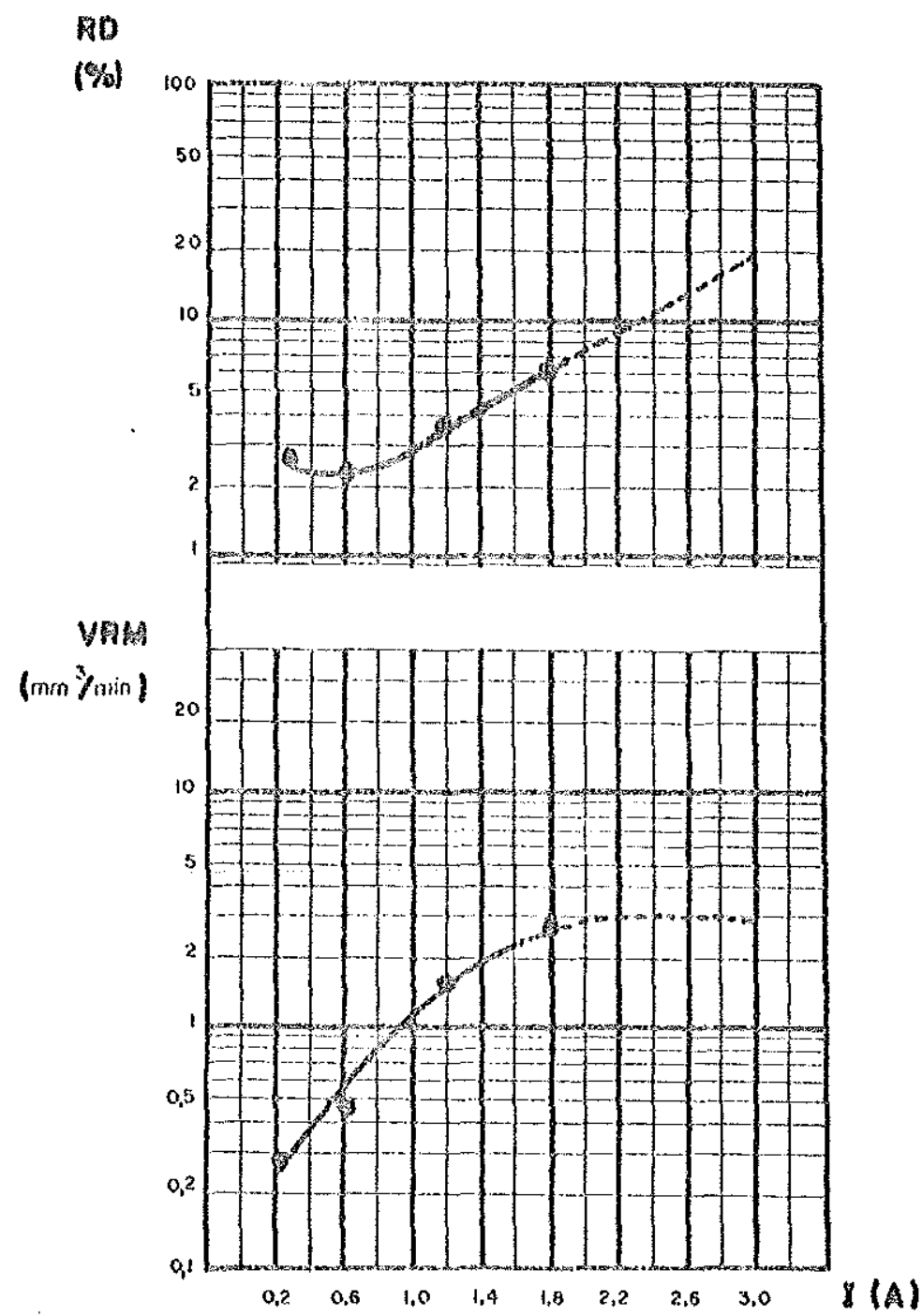

Fig. 64 - Relação de desgaste e velocidade de remoģão de material. em função da corrente de descarga 
Regime de usinagem: ACABAMENTO

polaridade do elëtrodo-ferramenta: positiva

Condições de ensaio: $A_{E}=31,55 \mathrm{~mm}^{2}$ $36,00 \mathrm{~mm}^{2}$
$44,55 \mathrm{~mm}^{2}$

Dielétrico: querosene

Injeção ou suç̧ão: $2,5 \times 10^{4} \mathrm{~Pa}\left(0,25 \mathrm{Kgf} / \mathrm{cm}^{2}\right)$

Tensão de ajuste: $105 \mathrm{~V}$

Capacitäncia do circuito de carga: $C=286 \mathrm{nF}$

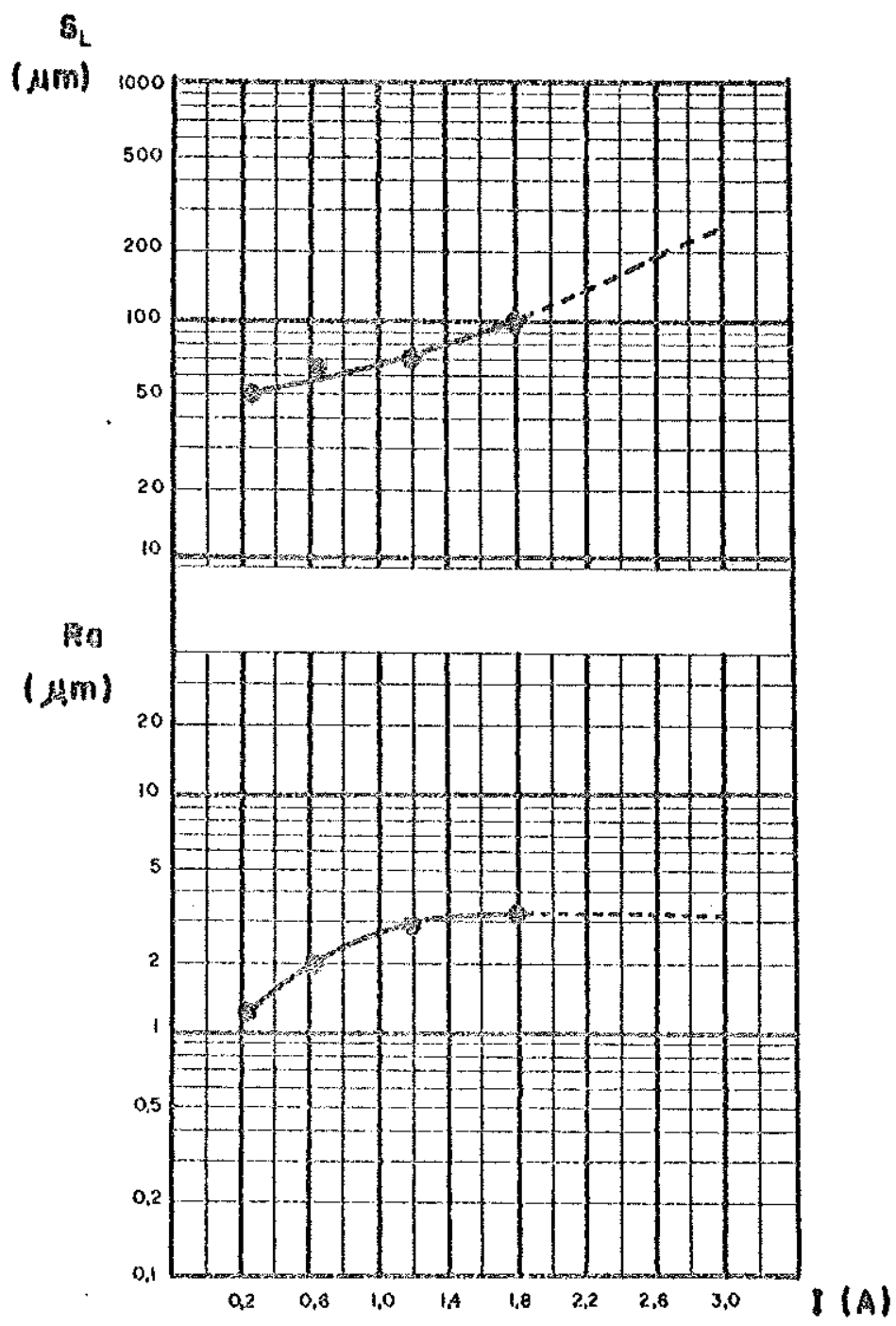

Fig. 65 - Sobrecorte lateral e rugosidade superficial da peça usinada em função da corrente de descarga 
Regime de usinagem: ACABAMENTO

polaridade do elétrodo-ferramenta: positivo

Condições de ensaio: $A_{f:}=36,51 \mathrm{~mm}^{2}$

$$
\begin{aligned}
& 40,96 \mathrm{~mm}^{2} \\
& 44,55 \mathrm{~mm}^{2}
\end{aligned}
$$

Dielétrico: querosene

Injeção ou suç̧ão: $2,5 \times 10^{4} \mathrm{~Pa}\left(0,25 \mathrm{Kgf} / \mathrm{cm}^{2}\right)$

Tensão de ajuste: $11.0 \mathrm{~V}$

Capacitância do circuito de carga: $C=1086 \mathrm{nF}$

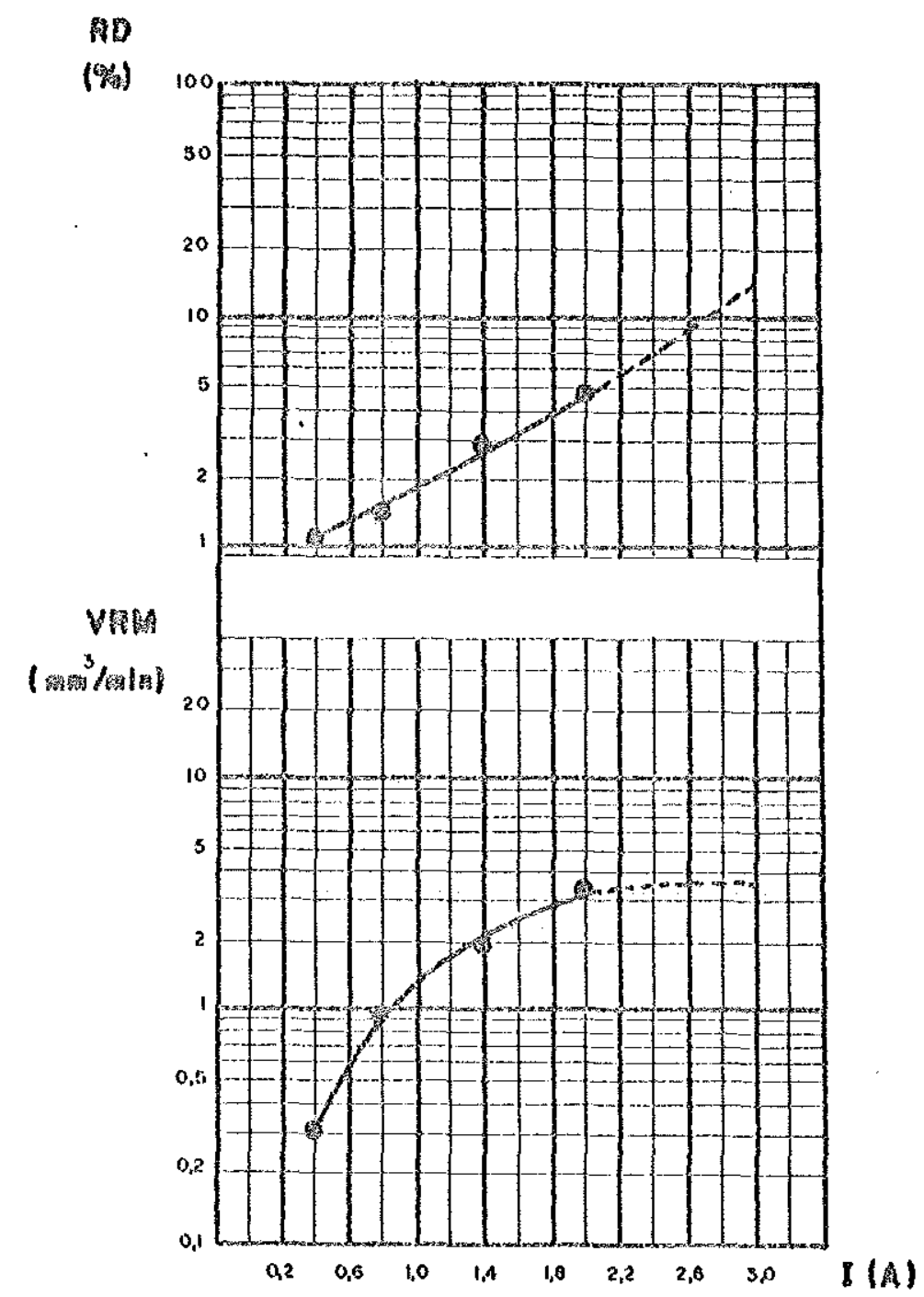

Fig. 66 - Relação de desgaste e velocidade de remoção de material em função da corrente de descarga 
Regime de usinagem: ACABAMENTO

Polaridade do elétrodo-ferranenta: positiva

Condições de ensaio: $A_{f .}=36,51 \mathrm{~mm}^{2}$

$40,96 \mathrm{~mm}^{2}$

$44,55 \mathrm{~mm}^{2}$

dielëtrico: querosene

Injeção ou suç̧äo: $2,5 \times 10^{4} \mathrm{pa}\left(0,25 \mathrm{Kgf} / \mathrm{cm}^{2}\right)$

Tensão de ajuste: $110 \mathrm{~V}$

Capacitância do cjrcuito de carga: $1.086 \mathrm{nF}$

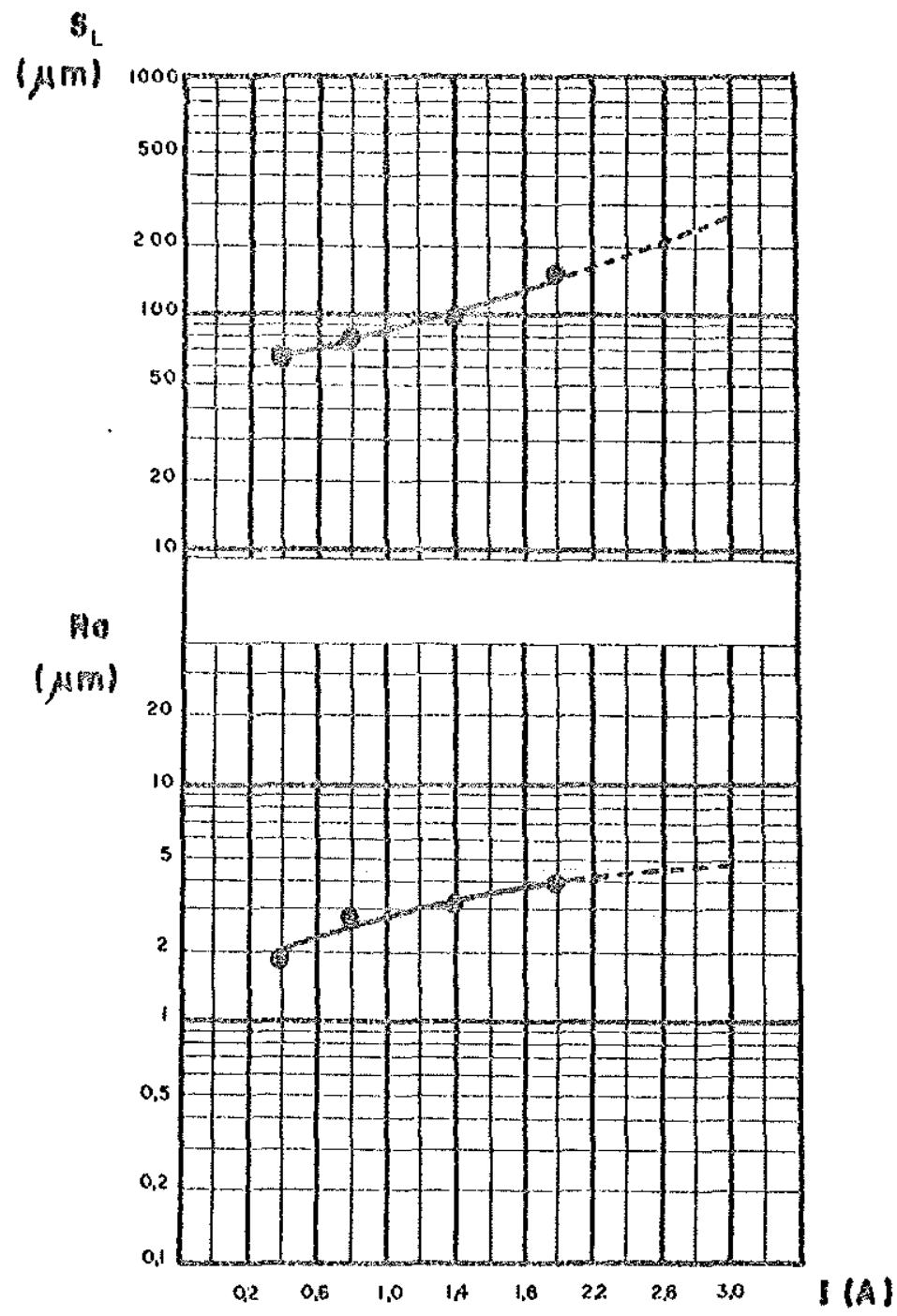

Fig. 67 -. Sobrecorte lateral e rugosidade superficial da peça usinada em função da corrente de descarga 
Regime de usinagen: ACABAMENTO

polaridade do elétrodo-ferramenta: positiva

Condições de ensaio: $A_{\hat{F}}=36,51 \mathrm{~mm}^{2}$ $40,96 \mathrm{~mm}^{2}$

$44,55 \mathrm{~mm}^{2}$

Dielëtrico: querosene

Injeção ou sucção: $2,5 \times 10^{4} \mathrm{~Pa}\left(0,25 \mathrm{Kgf} / \mathrm{cm}^{2}\right)$

Tensão de ajuste: $110 \mathrm{~V}$

Capacitância do circuito de carga: 1,5 $\mu \mathrm{F}$

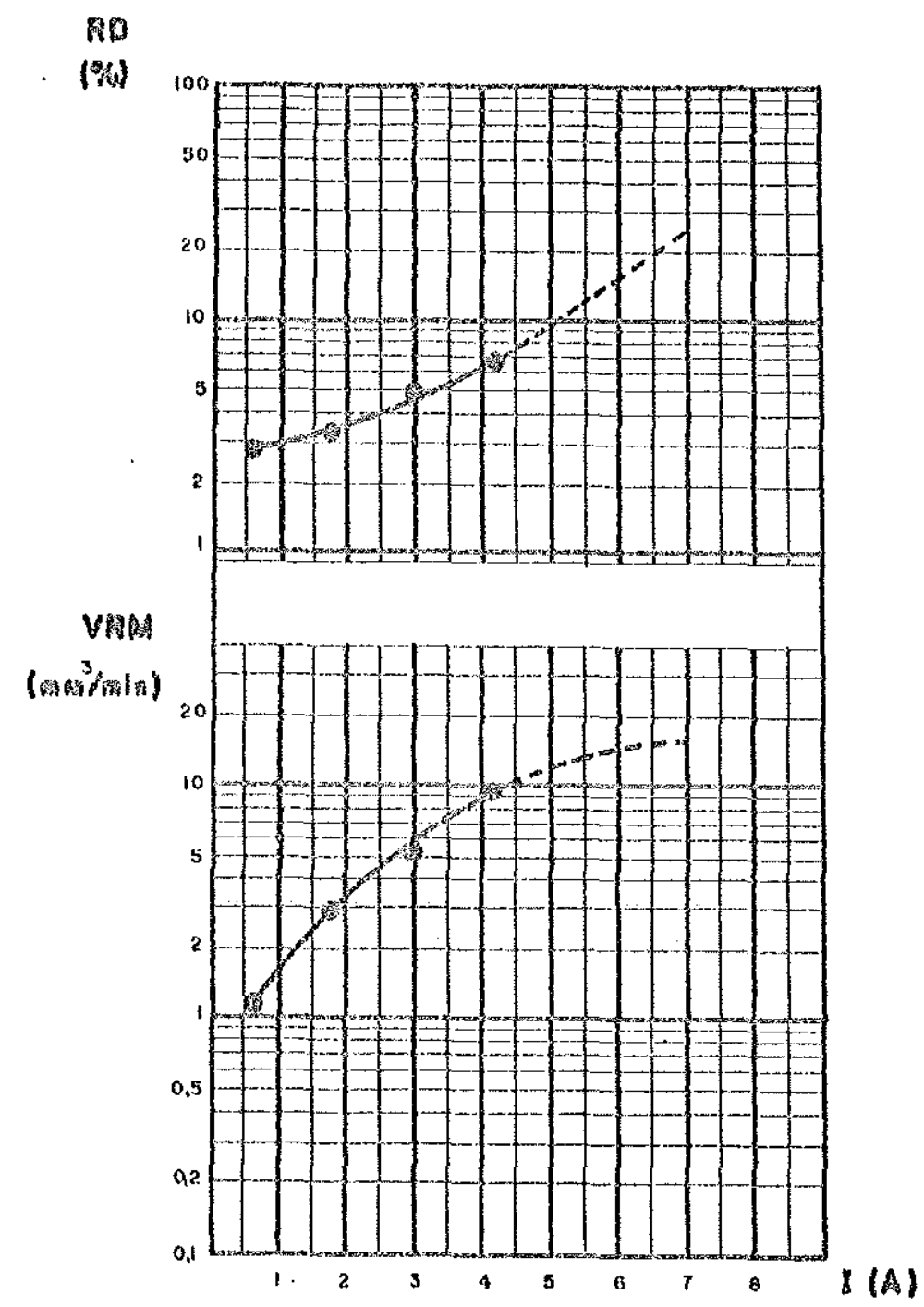

Fig. 68 - Relação de desgaste e veloćidade de remoção de material. em função da corrente de descarga 
Regime de usinagem: ACABAMENTO

Polaridade do elëtrodo-ferramenta: positiva

Condições de ensaio: $A_{f}=36,51 \mathrm{~mm}^{2}$

$$
\begin{aligned}
& 40,96 \mathrm{~mm}^{2} \\
& 44,55 \mathrm{~mm}^{2}
\end{aligned}
$$

Dielëtrico: querosene

Injeção ou sucção: $2,5 \times 10^{4} \mathrm{~Pa}\left(0,25 \mathrm{kgf} / \mathrm{cm}^{2}\right)$

Tensão de ajuste: $110 \mathrm{~V}$

Capacitância do ciccuito de carga: 1,5 $\mu \mathrm{F}$

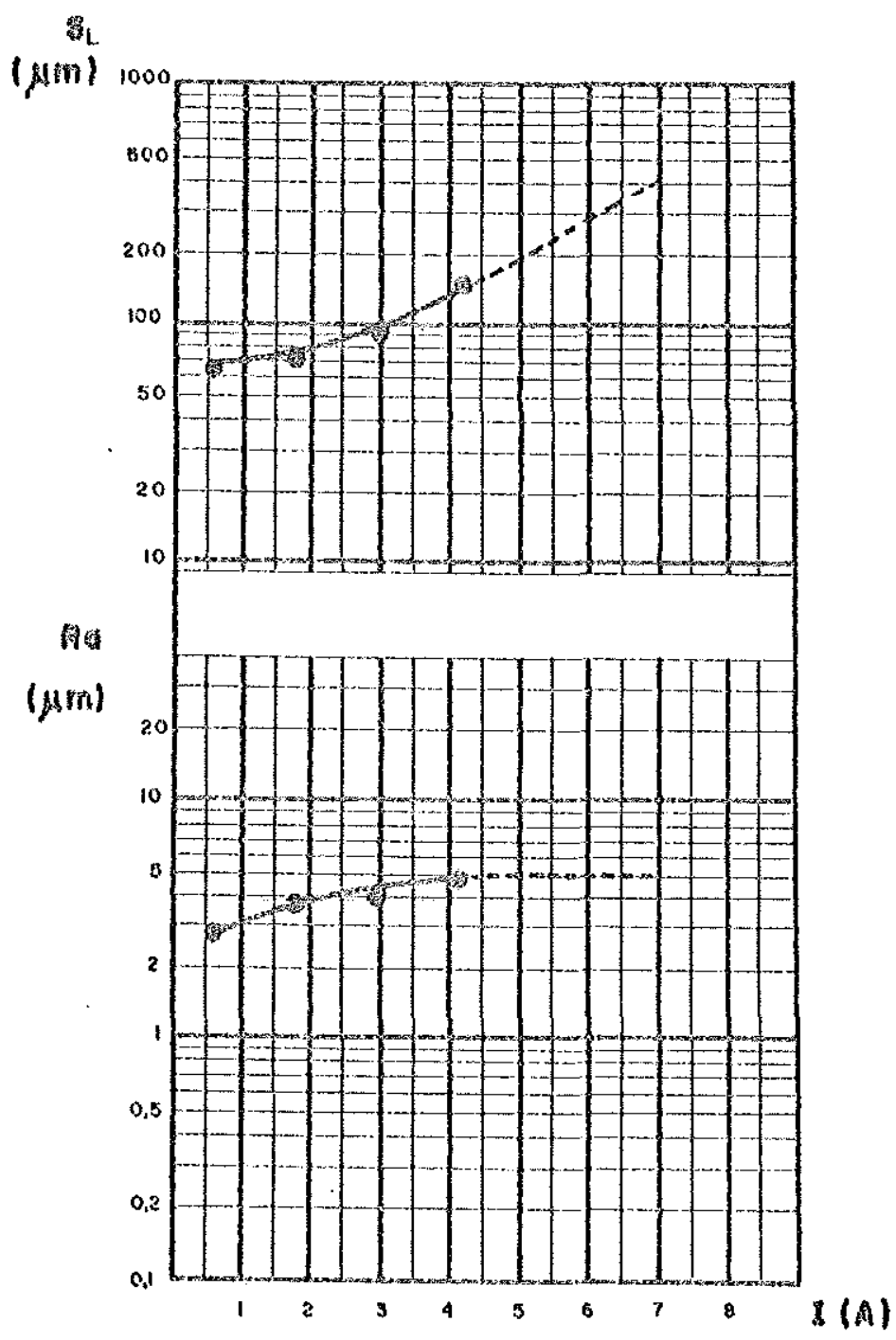

Fig. 69 - Sobrecorte lateral e rugosidade superficial da peça usinada em função da corrente de descarga 
Regime de usinagem: ACABAMENTO

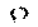

Polaridade do Flëtrodo-ferramenta: positiva

Condi.ções de ensiaio: $A_{f}=44,55 \mathrm{~mm}^{2}$

Dielëtrico: que rosene

Injeçäo ou sucção: $2,5 \times 10^{4} \mathrm{~Pa}\left(0,25 \mathrm{Kgf} / \mathrm{cm}^{2}\right)$

I'ensão de ajuste: $1.20 \mathrm{~V}$

Capacitância do circuito de carga: 1,5 $\mu \mathrm{F}$

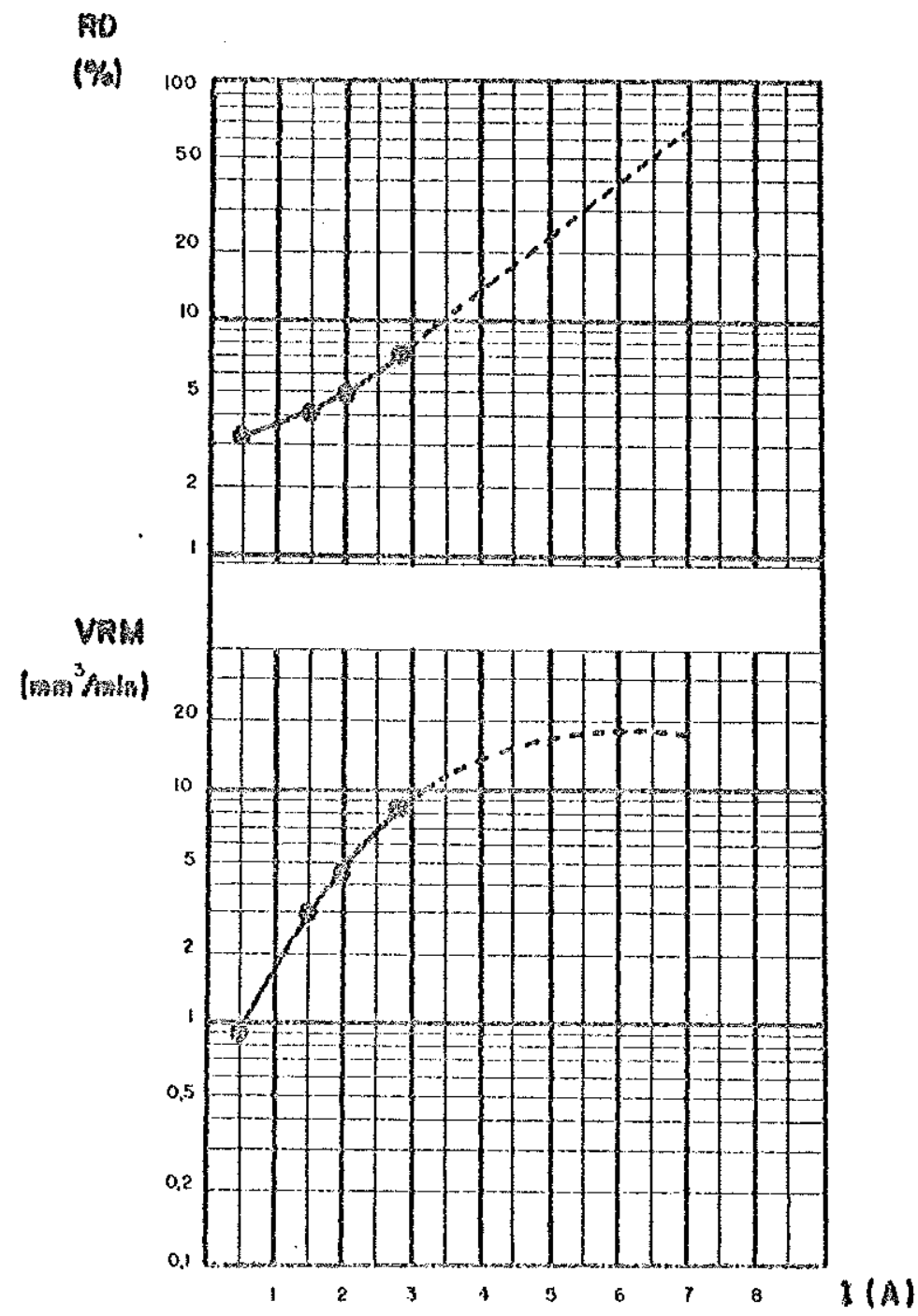

Fig. 70 - Relação de desgaste e velocidade de remoçä̃o de material em função da corrente de descarga 
Regime de usinagem: ACABAMENTO

Polaridade do elëtrodo-ferramenta: positiva

Condiçöes de ensaio: $A_{f}=44,55 \mathrm{~mm}^{2}$

Dielëtrico: querosene

Injeção ou sucção: $2,5 \times 10^{4}$ pa $\left(0,25 \mathrm{kgf} / \mathrm{cm}^{2}\right)$

Tensão de ajuste: $120 \mathrm{~V}$

Capacitância do circuito de carça: $1,5 \mu \mathrm{F}$

1

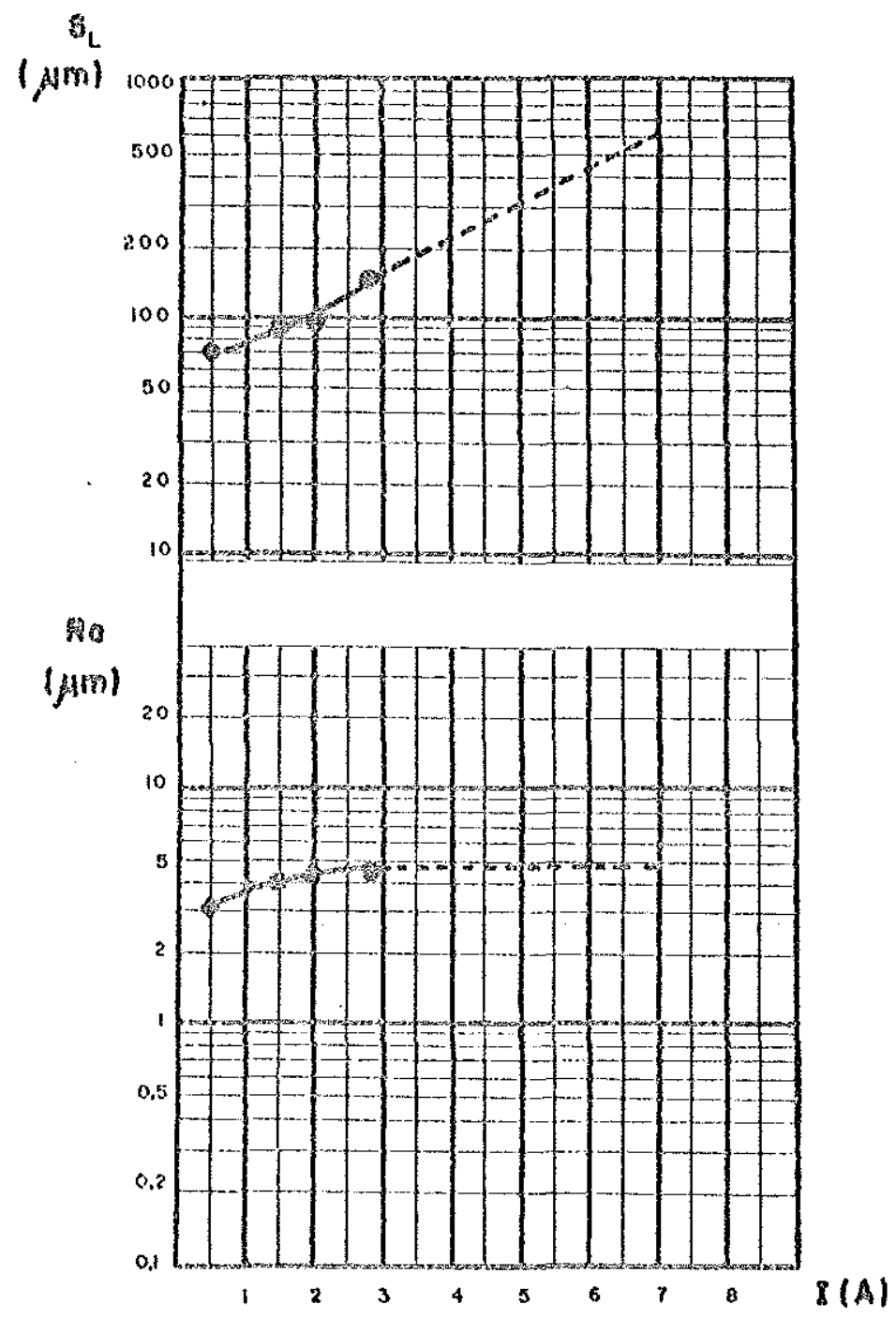

Fig. 71 - Sobrecorte lateral e rugosidade superficial da peça usinada em função da corrente de descarga 
Regime de usinagem: ACABAMENTO

polaridade do elétrodo-ferramenta: positiva

Condições de ensaio: $\Lambda_{E}=44,55 \mathrm{~mm}^{2}$

bielëtrico: querosene

Injeção ou suç̧ão: $2,5 \times 10^{4} \mathrm{~Pa}\left(0,25 \mathrm{kgf} / \mathrm{cm}^{2}\right)$

Tensão de ajuste: $110 \mathrm{~V}$

Capacitância do circuito de carga: 4,5 $\mu \mathrm{F}$

1

a

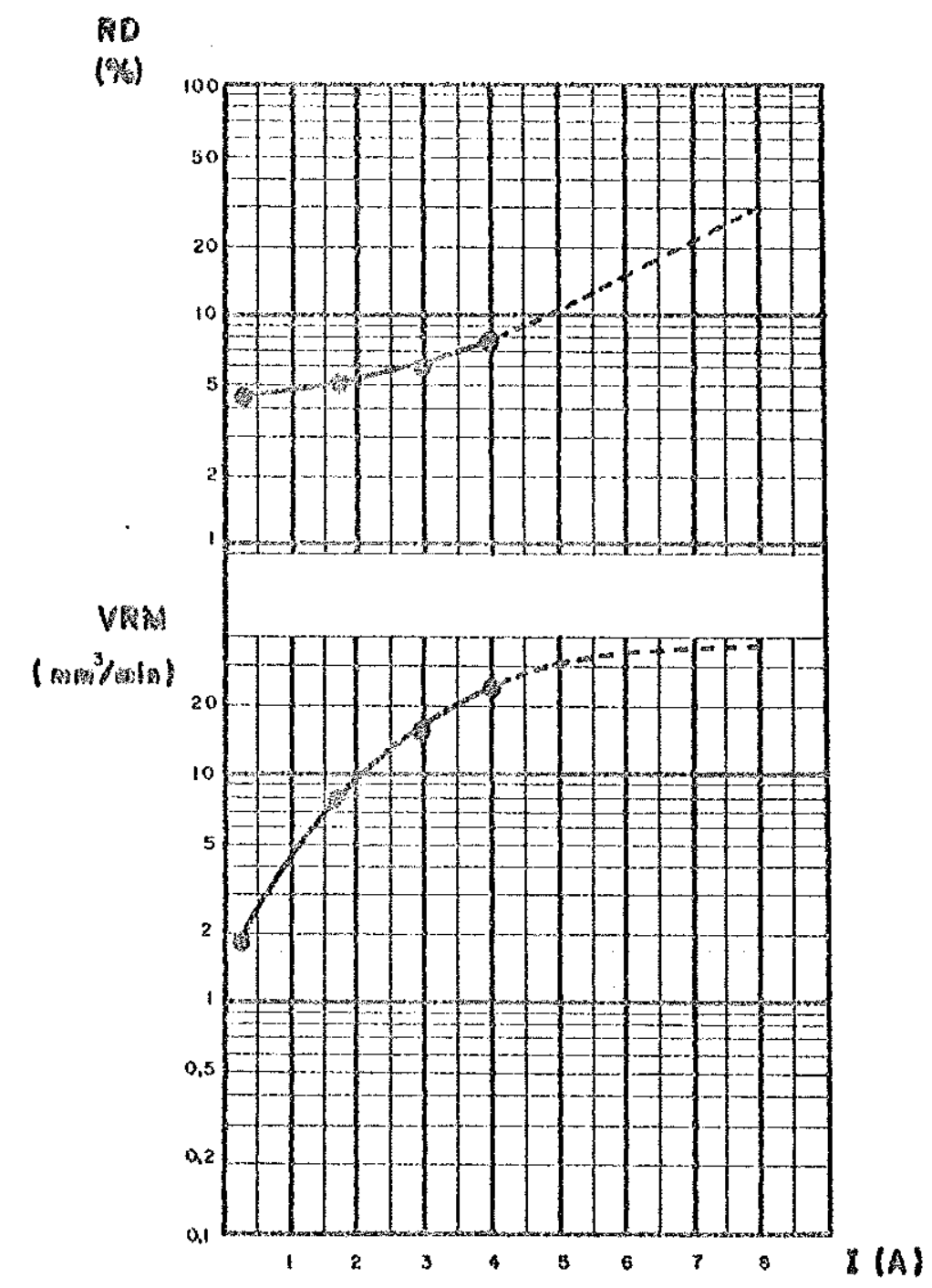

Fig. 72 - Relação de desgaste e velocidade de remoção de material em função da corrente de descarga 
Regime de usinagem: ACABAMENTO

polaridade do elëtrodo-ferramenta: positiva

Condições de ensaio: $A_{F}=44,55 \mathrm{~mm}^{2}$

Dielëtrico: querosene

Injeção ou suç̧ão: $2,5 \times 10^{4} \mathrm{~Pa}\left(0,25 \mathrm{kgf} / \mathrm{cm}^{2}\right)$

Tensão de ajuste: $11.0 \mathrm{~V}$

Capacitância do circuito de carga: $4,5 \mu \mathrm{F}$

$$
3
$$

$(\mu m)$.

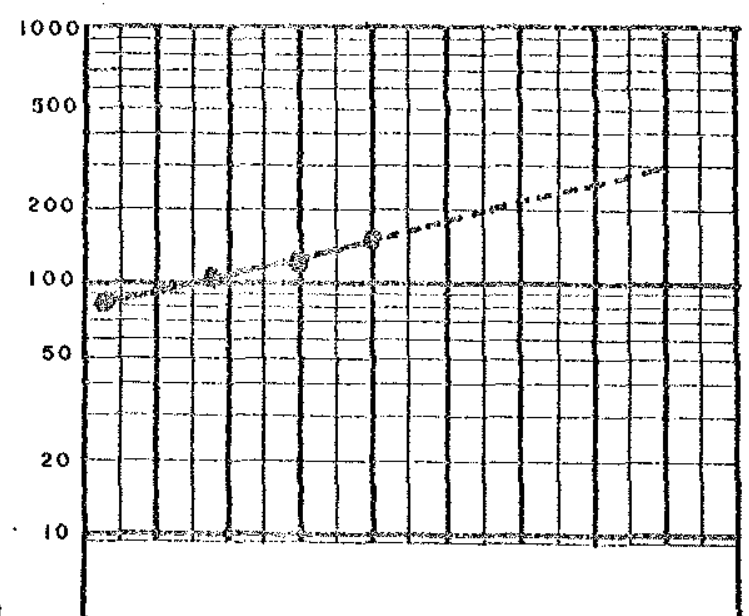

mit

(

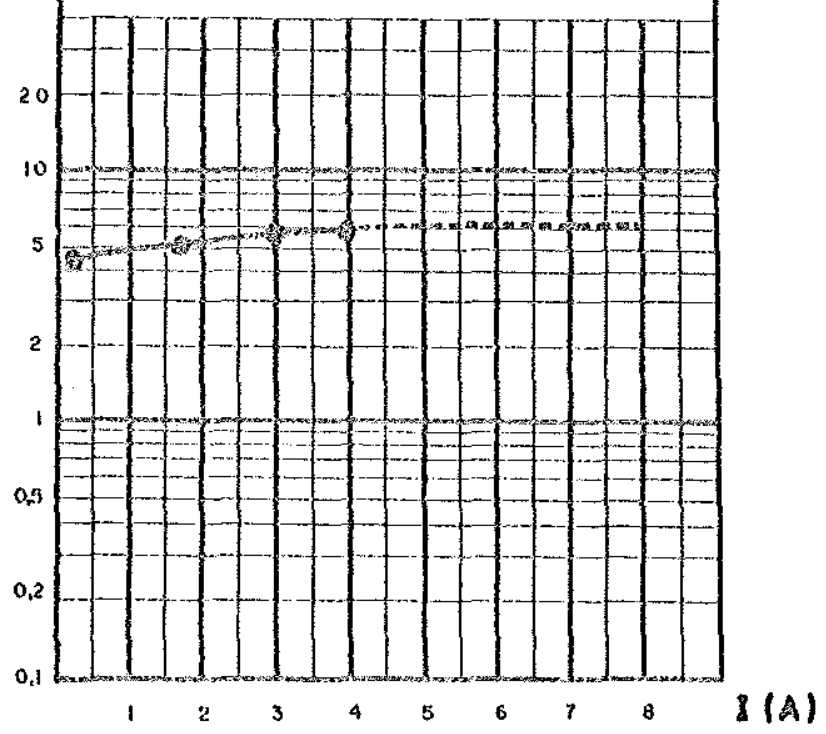

Fig. 73 - Sobrecorte lateral e rugosidade superficial da peça usinada en função da corrente de descarga 
Regime de usinagem: ACABAMEN'TO .

Polaridade do eletrodo-ferramenta: positiva

Condiçöes de ensato: $A_{f}=40,96 \mathrm{~mm}^{2}$ $44,55 \mathrm{~mm}^{2}$

Dielëtrico: querosene

Injeção ou sucção: $2,5 \times 10^{4} \mathrm{~Pa}\left(0,25 \mathrm{kgf} / \mathrm{cm}^{2}\right)$

Tensäo de ajuste: $1.25 \mathrm{~V}$

Capacitância do circuito de carga: $4,5 \mu F$

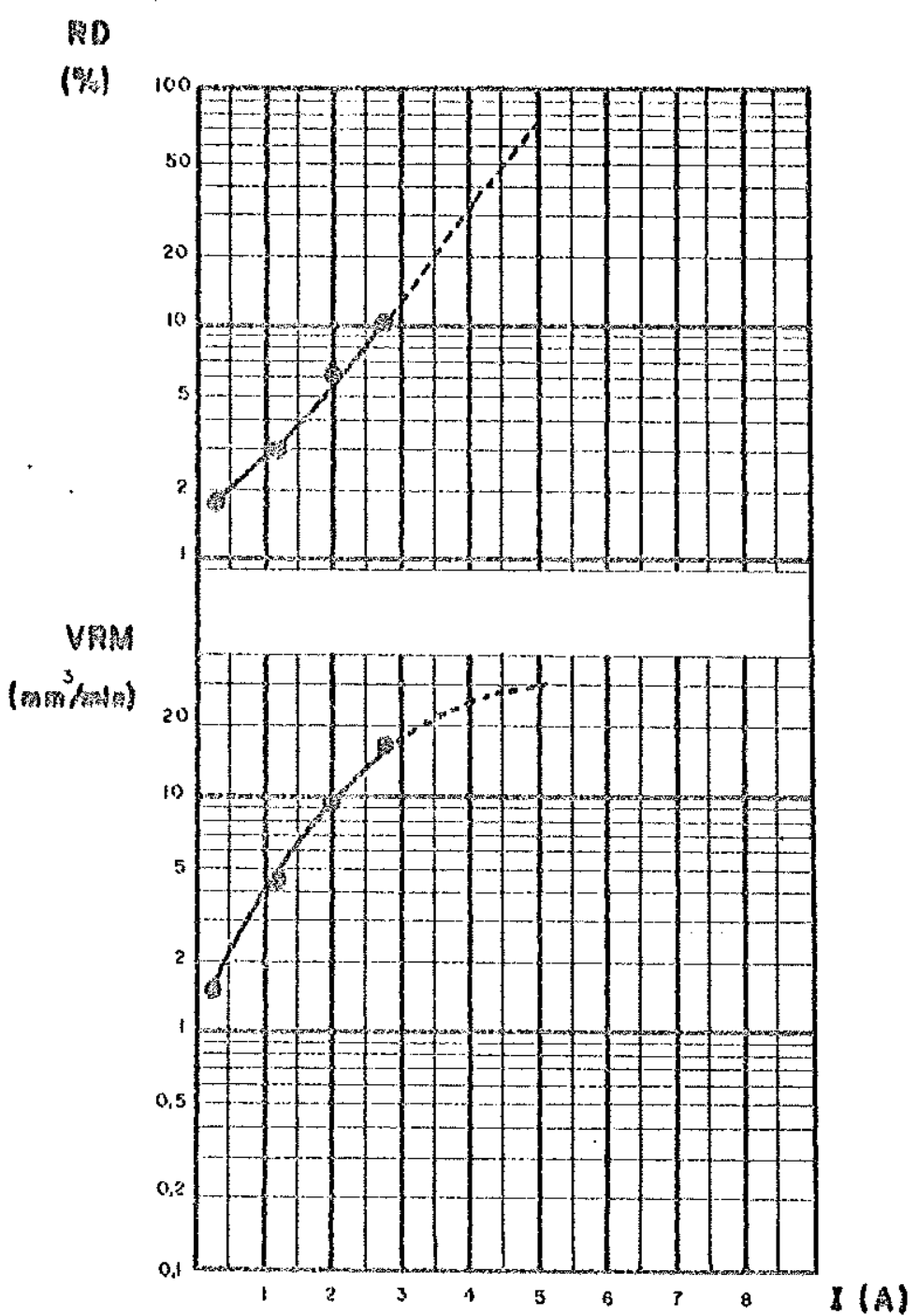

Fig. 74 - Relação de desgaste e velocidade de remoção de material em função da cor rente de descarga 
Regime de usinagen: ACABAMENTO

i)

Polarjade do elétrodo-ferramenta: positiva

Condigões de ensaio: $A_{f}=40,96 \mathrm{~mm}^{2}$ $44,55 \mathrm{~mm}^{2}$

Dielëtrico: querosene

Injeção ou suç̧ão: $2,5 \times 10^{4} \mathrm{~Pa}\left(0,25 \mathrm{kgf} / \mathrm{cm}^{2}\right)$

Tensão de ajuste: $125 \mathrm{~V}$

Capacitância do circuito de carga: $4,5 \mu \mathrm{F}$

$r$

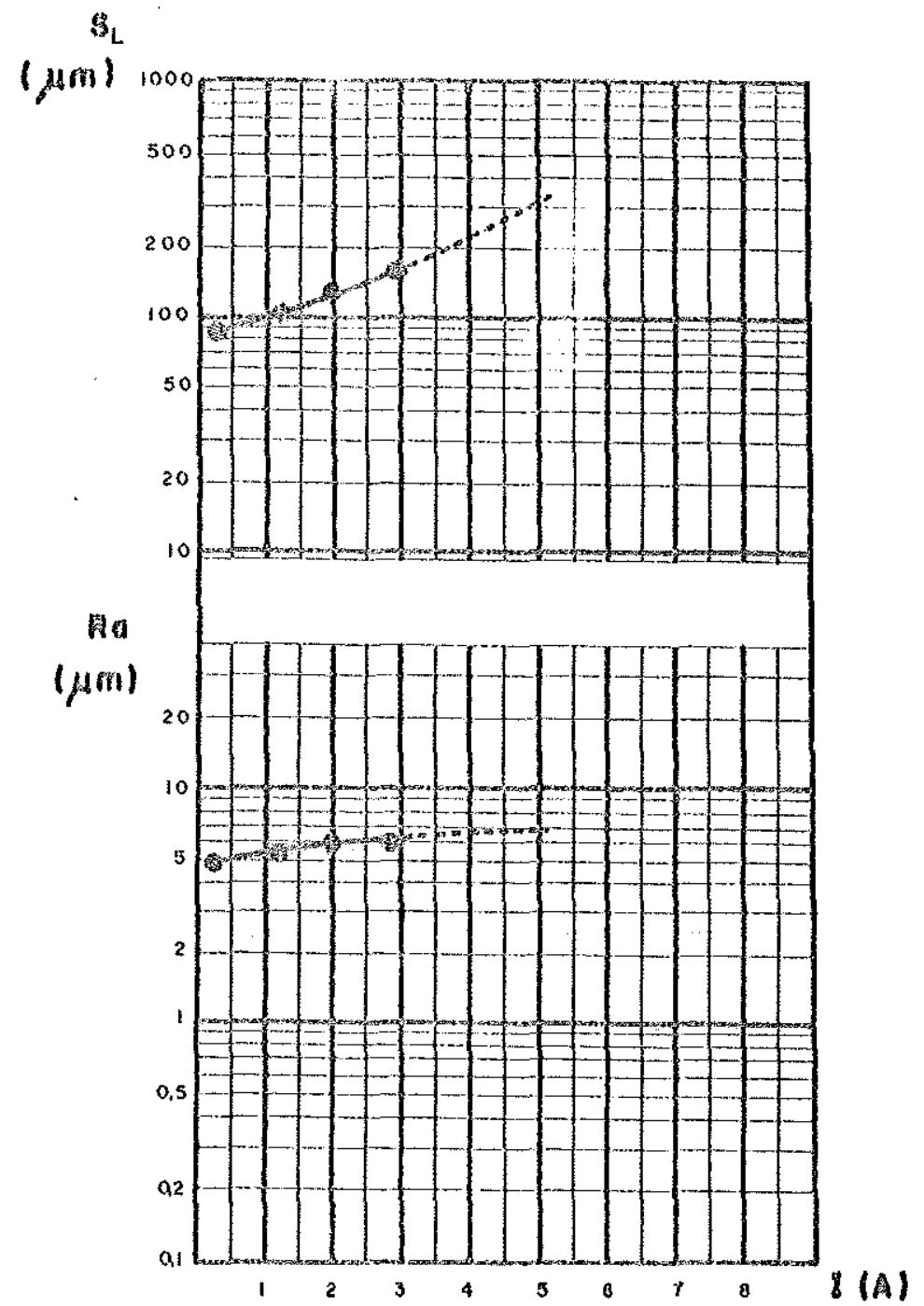

Fig. 75 - Sobrecorte lateral e rugosidade superficial da peça usinada em função da corrente de descarga 
Constatou-se, durante a experimentação, que os e

feitos de dispersão da energia da descarga são maiores para usinagens profundas e com sistema de lavagem deficiente. Nesses casos, as partículas removidas não são expulsas como deveriam da zona de usinagem, seja frontal, seja late ral. Ora, isso ocorre também na irrigaçäo de um solo: à me dida que a profundidade da camada a ser irrigada aunenta, aumenta a dispersäo da àgua fornecida ao sistema, aumentan do igualmente as perdas do processo.

o tempo de duração e o propprio processo da descarga são condicionados em grande parte à capacitância, à resistência e à indutância própria do circuito de descarga, nos circuitos de relaxação, como o que foi utilizado. o aumento do tempo de duração da descarga, atravës do aumento dessas grandezas, acarreta na majoraçäo das perdas térmicas da enexgia, constatadas, nos ensaios efetuados, pela monitoração da temperatura do banho dielëtrico de lámvagem da peça, bem como pelo aquecimento sensivel dos elë-trodos, detectado pox contato manual após cada ensajo. Isso ocasiona, obviamente, a queda do rendimento do processo, espelhada de forma soberba nos ensaios de desbaste (Fi guras 56 e 57 ).

As linhas tracejadas de cada figura representam - comportamento esperado de cada uma dessas curvas sob con dições adequadas de usinagem, tais como ärea frontal ötima do elétrodo-ferramenta, condiçōes de lavagem, nível de con taminação do líquido dielëtrico, tamanho dos grãos dos elé txodos etc. Foram extrapoladas de acordo com o comportamen to obtido para essas curvas pelos diversos pesquisadores da ärea e publicados em diversos artigos, listados nas referências bibliogräficas deste trabalho.

A relação de desgaste obtida foi maior que a es" perada, de uma maneira gexal. Apenas os ensajos com polari dade invertida dos elétrodos (Figuras 62 a 75 ) apresentaram os rilveis desejados de relação de desqaste. Isso se deveu, 
em parte, à baix xa contaminação do dielétxico, jả que nos ensajos de desbaste não se empregou a unidade de filtragell; além disso, o sistema de lavagem utilizado mostrou-se ser deficiente e, ra tentativa de melhorá-10, aumentou-se a pressão de lavagem $\left(2,5 \times 10^{4} \mathrm{~Pa}\right)$ o que também contribuiu para a majoração do desgaste do elétrodo-ferramen ta. Manteve-se constante essa pressão de lavagem para que a comparação global entre os ensaios pudesse ser embasada em condições semelhantes.

- comportamento das curvas de relação de desgas te versus corrente de descarga apresentou uma mesma característica em todos os regimes de usinagem usados: concavidade voltada para cima.

Nos ensaios de desbaste, a relação de desgaste foi decrescendo com o aumento da corrente de descarga; isso se deve à alta contaminação do dielétrico e ao pequeno "gap" de serviço, expondo com maior intensidade o elétrodo - ferramenta aos efeitos térmicos das descargas elétricas.

Nos ensaios de acabamento com polaridade normal, ou seja, com a ferranenta sendo o cátodo do cixcuito (Figu ra 60) hä uma súbita majoração no desgaste da ferramenta correspondendo a uma violenta variação na capacitância do circuito de carga, que "salta" de $163 \mathrm{nF}$ para $2.083 \mathrm{nF}$, um aumento da quase treze vezes.

Invertendo-se a polaridade do circuito, nos ensaios de acabanento, constata-se uma inversão de comportamento do desgaste da ferramenta, que associa baixas correntes de descarga a baixas relações de desgaste. Isto se deve ao fato de que, sob essa polaridade, algurnas particulas erodidas da pega usinada soldam-se à superfície da fex ramenta; à medida que se aumenta a energia de descarga, a massa e, consequentementè, a inércia dessas partículas, é maior e o "efeito ímã" è afetado.

Isso tanbëm explica a inversão de comportamento do sobrecoxte Jateral que, com polaridade invertida do circuito, apresenta uma concavidade voltada para cima. As par 
tículas removidas da peça e "varridas" pela circulação do fluido dielétrico, ainda que no sistema de lavagem por suc ção, aumentam paulatinamente de tamanho com o aumento da e nergia da descarga e ampliam, cada vez mais acentuadamente, o sobrecorte lateraj, para possibilitar o seu livre trầnsito.

As curvas de rugosidade superficial da peça usinada versus corrente de descarga apresentam um comportamen to independente da polaridade do circuito, mas altamente influenciadas pela energia da descarga até um determinado Jimite, apös o qual a rugosidade superficial passa a ser constante.

A umidade relativa do ar não exerceu qualquer in fluência perceptível no desempenho do processo, apesar de que ela altera as características dielétricas do fluido de serviço. Durante os enssaios, variou desde 50 até $80 \%$.

A temperatura ambiente interage diretamente corn a temperatura do banho dielétrico. A máxima variação detẹ tada entre ambas foi de $4,0{ }^{\circ} \mathrm{C}$. Convëm salientar que a monit.oração da temperatura do banho dielétrico foi executada junto ao termodetector do fluido do reservatóxio de serviço. Enquanto a temperatura ambiente variou de 18 a $28{ }^{\circ} \mathrm{C}$, durante a realização da experimentação, a temperatura do banho dielétrico flutuou en uma faixa de 20 a $30^{\circ} \mathrm{C}$.

A temperatura altera a viscosidade do fluido die létrico; un aumento naquela provoca uma diminuição nesta, melhorando a lavagem da zona de usinagen.

A tensão de ajuste influiu significativamente nas condiçŏes de usinagem. Esse efeito foi observado nos ensaios de números 43 a 50 e 51 a 58 . Diminuj.ndo a tensão de ajuste, nos cixcuitos de relaxação, majora-se a frequên cia de descargas, melhora-se o acabamento superficial, diminui.-se o sobrecoxte latexal e o desgaste do elëtrodo-fer ramenta, mas em detrimento da velocidade de remoção de material. A recíproca é verdadeira. 
o avanço do cabeçote, no tempo, mostrou ter um comportamento idêntico àquele da velocidade de remoção de material versus a corrente de descarga.

Observou-se qualitativamente que os números de Reynolds, relativos à circulação do filuido no reservatório de serviço e na zona de usinagem, influem ponderavelmente na estabilidade do processo e, consequentemente, na precisão dimensional, acabamento superficial e tempo de fabrica ção da peça usinada.

A lavagem por injeção lateral, usada nos ensaios, mostrou ser mais indicada que a lavagen por sucção, desde que o desgaste do elétrodo-ferramenta, a conicidade e o acabamento superficial da peça usinada, não sejam tão impor tantes. Bla permite a obtenção de maiores velocidades de remoção de material, é mais facilmente utilizada e se aplí ca a qualquer emprego do processo. Com a inversão da polaridade, a conicidade mäxima verificada, utilizando-se lava gem por injeção lateral, foi de $1^{\circ}$ en cada lado da cavidade executada, enquanto a máxima relação de desgaste foi de $10 \%$, como se observa nos gráficos e tabelas dos resultados obtidos .

Ao se cortar transversalmente una barra constitu ida de um tipo especial. de aço inoxidável ern desenvolvimen to na EESC-USP, de baixa usinabilidade mecânica, com una barra de aço-carbono de espessura 0,8 mm, mono-engastada no suporte de fixação da ferramenta, observou-se a presença de forças significativas no processo, como pode ser deduzido da anäljse da Figura 76 .

Vexificou--se que os efeitos da vibração excessiva do porta-elétrodo podem ser altamente danosos à peça u-sinada, quando a ferramenta tem baixa rigidez, como o elëtrodo da direjta, da Figura 76; à esquerda, apresenta-se um elétrodo con maior rigidez, com o qual se obteve uma usina gem sern maiores problemas, mas com o triplo do tempo de usinagem que seria obtido com o elétrodo anterior, para o regime selecionado (acabamento, polaridade normal). 


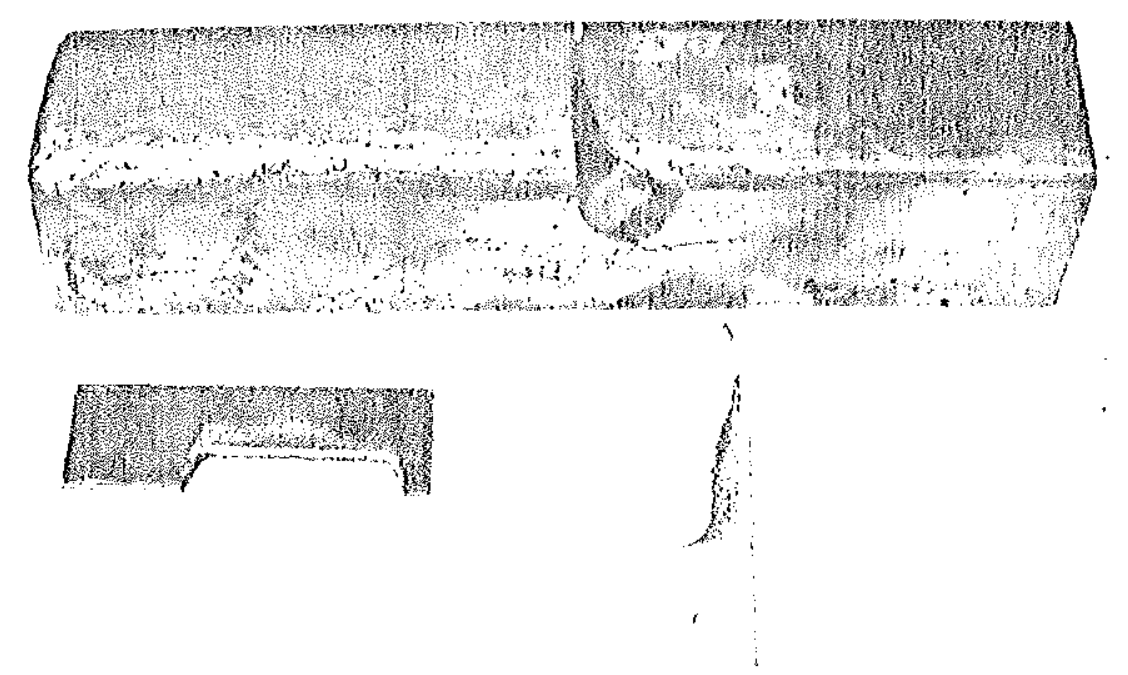

Fig. 76 - Peça de aço inoxidävel cortada com e]êtrodos de aço-carbono

Apesar de não haver forças de corte significativas devido à usinagem por eletroerosão propriamente dita, a ferramenta vibra, devido principalmente à vibração do cá beçote da mäquina, hidraulitcamente acionado. A Figura 77 mostra o instante em que o elétrodo-ferramenta, já deforma do, entra em contato com o fluido díelétrico no reservatório de serviço.

Aqui, o cabeçote porta-elëtrodo está "parado" "pa ra que se evidenciem as franjas, no fluido dielëtrico, oriundas da vibração do cabeçote poxt:a-rerramenta. Em opera ções de desbaste, com "gaps" elevados, não hã efeitos significativos sobre o processo; en operaçōes de acabamento, entretanto, con "gaps" reduzidos, há tendência à formação de curtos-circuito entre os elétrodos e, consequentemente, instabilidade na usinagem, prejudicando assim a acuracidade do processo. 


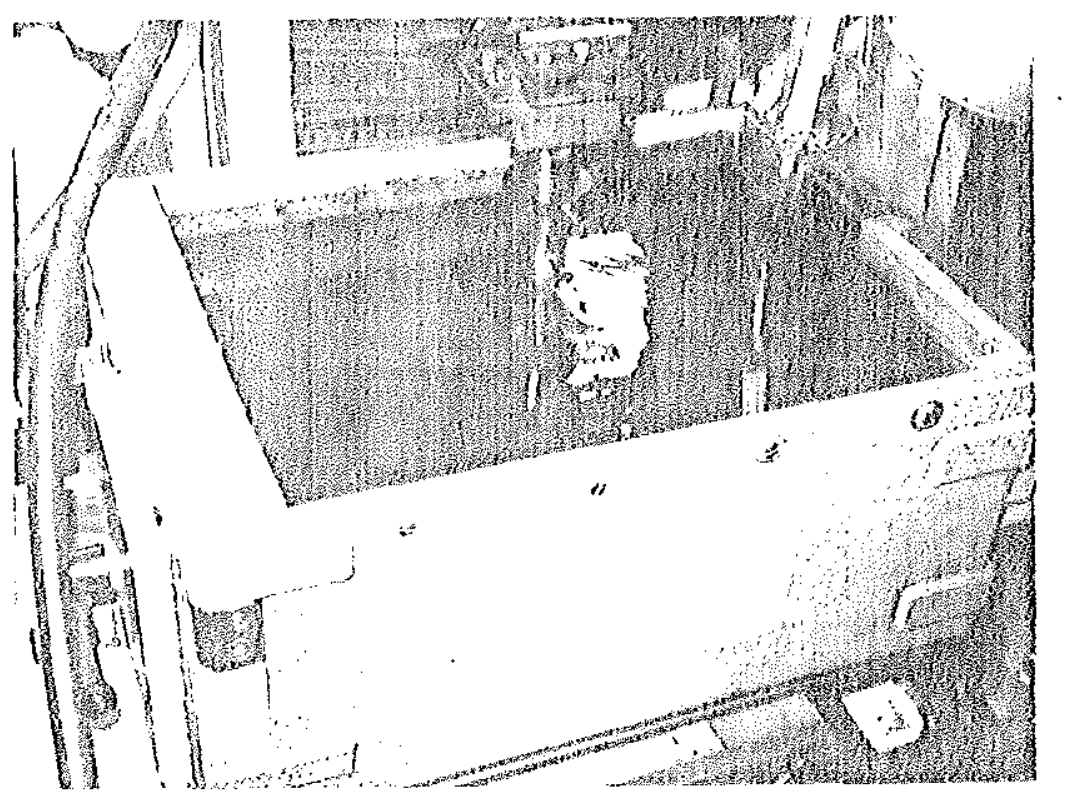

3

3
Fig. 77 - Franjas, no fluido dielétrico, provenientes da vibração excessiva do cabeçote eletroerosivo 
7. CONCLUSÕES. SUGESTOESS PARA TRABALHOS FUTUROS

a

\subsection{Conclusöos}

(1)

Apresentarammse os parâmetros tecnolögicos que influem mais significativamente no processo de usinagem por eletroerosăo. A anälise dos resultados experimentais mostra que a energia da descarga influi decisivamente nos parâmetros de saída da UEE. O tempo de fabricação, o acabă mento superficial e a conicidade dá peça usinada, o desgas te do elétrodo-ferramenta e a espessura da camada superficial da peça usinada afelada pejo calor, são funçöes dessa energia.

o parâmetro maiss importante do processo ë, indis cutivelmente, a energia da descarga. Nos circuitos de rela xação, ela depende da capacitância do circuito de carga e da tensão no capacitor. o valor da tensão no capacitor depende da tensão de ajuste e do espaço compreendido entre os elétrodos. A diminuição do "gap" provoca uma queda na tensão do capacitor e o aumento da frequência de descargas. A resistência do circuito de carga jimita o valor da 
corrente de descarga e seleciona o regime de usinagem pretendido.

A área frontal do ejëtrodo-ferranenta ë outro pa râmetro bäsico a ser considerado na seleçăo das condições ótimas de usinagem. Altos níveis de energia da descarga, quando aplicadas a áreas pequenas, provocam uma acentuada instabilidade de usinagern, caracterizada pela elevação da temperatura do banho dielétrico, geração de ruído e aumento da frequência de contatos físicos entre os elétrodos.

Os parâmetros hidrodinâmicos do fluido dielétrico no reservatório de serviço e na zona de usinagem, a geo metria, as propriedades físicas e metalúrgicas dos elëtrodos e a contaminação do filuido dielétrico, são outros fato res a serem considerados na UEE.

Os efeitos da vibração excessiva do cabeçote por ta-ferramenta evidenciarall-se durante a usinagem de aço inoxidâvel com elétrodo de aço-carbono, mostrando haver o desenvolvimento de forças significativas durante a usinagem, provententes de contatos metälicos entre os elétrodos, devido às falhas operacionats do servo-sistema de comando do avanço do cabeçote eletroerosivo.

\subsection{Sugestöes para Trabalhos Futuros}

Ante a necessidade de se desenvolverem novas pes quisas na área de usinagem por eletroerosão, imprescindí veis à seleção dos parâmetros tecnológicos ótimos do processo, para una dada apli.cação, Jistam-se alguns experimen tos que podem sex efetuados:

a) Estudo da infiluência dos parâmetros tecnológ cos sobre o desempenho do processo através do agrupamento das variáveis em parâmetros adiInensionais e esboço dos gráficos relacionando tais parâmetros, obtidos em ensaios. 
b) Estudo das características dinâmicas do servo - sistema de comando do avanço do cabeçote pos ta-ferramenta.

c) Anālise dinâruica da estrutura da máquina-ferramente ejetroexosiva, sob condições operacio nais.

d) Projeto e construção de unidades de filtragem e resfriamento do dielétrico, que permitam o controle da contaminação e temperatura do banho dielëtrico, comparando os seus desempenhos em serviço.

e) Utilização de âgua desionizada como fluido de serviço e comparação com os resultados obtidos empregando-se o querosene.

f) Projeto e desenvolvimento de novas ligas que assegurem boas características tërmicas, elëtricas e de custo do elétrodo-ferramenta e the possibilitem uma fabricação exequivel para qualquer: geometria da cavidade a ser execu tada. 
8. BIBISIOGRAFIA

8.1. Referências Bibliográficas

1. FERRARESt, D. - Fundamentos da usinagen dos metais. São Paulo, Edgard Blïcher, 1970. v.1, p.25.

2. MICHELETTT, G. F. - Măquinas ferramentas para usinagem na produção. Säo Carlos, EEsc-usp, 1979. v. 2, pa ginação irregular.

3. SPRTNGBORN, R. K., ed. - Non-traditional machining processes. Dearborn, Amexican Society of tool and manufacturing engineers, 1967. $1.78 \mathrm{p}$.

4. SVEDBERG, T. - Arkiv foer kemi. Minexalogi och Geologi, 2. (paper 40), 1906.

5. KOHLSCHUT'leR, V. - zejtschrift für Elektrochemje und angewandte physikalische chemie, 25, 1919. p. 309 . 
6. LEWINSON, J. M. et alii - production of cavities and holes in metals by the electro spark process. Berlin, VEB Verlag Technik, 1.954 .

7. TAREEV, B. - Physics of diejectric materials. Moscow, MIR, 1979. P. 57-59.

8. HUNTRESS, E. A., ed. - Electrical-discharge machining. American Machinist, p. 86, Aug. 1978.

9. SEMON, G. - Guide pratique d'usinage par étincelage. Suisse, nteliers des Charmilles, 1974.

3.0. BELLOWS, G. -- Thexmal non-traditional machining. Cincinnatj, Non-traditional machining guide, 1976.

11. MEDEIROS, J. T. N. \& SANTOS, J.M. C. - Usinagem por eletroexosäo. São carlos, Essc-usp, 1979. p.36.42 . Não publicado.

12. RODRIGUES, A. C. S. et alii - Usinagem dos metais por descargas elëticas. Campinas, UNCCAMP, 1974. p. 47-48. Não publicado.

13. VAN DIJCK, N. - Physico-mathematical analysis of EDM process. Thesis, Louvajn, 1973.

14. VAN DIJCK, $F$. \& SNOEYS - Plasma channel dianetex growth effects stock removal in ind. Annals of the CIRP, 21, 1972, P. 39-40.

15. MARTY, C. C. - Investigation of surface temperature in electro-discharge machining. Tramsactions of the ASME, Aug. 1977, p. 682-684. 
16. LASCOE, O. D. - Electro-discharge machining. purdue research sponsored by the IBM Corp., Endicott, New York. Purdue University, Lafayette, Indiana, USA, 1962 .

17. VAJPA, I, et alii - Study of the decomposition of kerosene used as a dielectric medium in spark machining. Periodica Polytechnica, Budapest, 11 , 1967 , p. 3-4.

18. HOCKENBERRY, T. O. - The role of the dielectric fluid in electrical discharge machining. I. Society of Automobile Engineering. (Paper 680635), 7-11, oct. 1968 .

19. DE BRUYN, H. E. - Some aspects of the influence of gap flushing on the accuracy in finishing by spark erosion. Annals of CIRP, 18, p. 147-151.

20. KARAFUJI, H. \& SUDA, K. - Study on electrical discharge machining. I. Journal of the Faculty of Engineexing, University of I'okyo, 27 (1): p. 1-18, 1965.

21. CROOKAIL, J. R. \& HEUVELMAN, C. J. - Electro-discharge machining - the state of the art. Annals of CIRP, 20 (2): p. $113-120,197 \mathrm{~L}$.

22. PORTO, O. L. \& CUPTNT, N. I. - Efeito do tamanho do grão na rugosidade do aluminio em eletroerosão. Máquinas \& Ferramentas, 1 (14): p. 102-105, 1980 .

23. MANUAL de instrucciones da mäquina eletroerosiva tipo Erosimat D-01/A - HITEKA. Budapest. 
8.2. Bibliografia Consultada

1. DANItEVSKY, V. -- Manufacturing engineering. Moscow, MIR, $1.973 .550 \mathrm{p}$.

2. DATSKO, J. - Matexial properties and manufacturing process. New York, John Wiley \& Sons, 1967, 543 p.

3. FRÖHLICH, H. - Theory of dielectrics. London, Oxford University Press, 1968. $192 \mathrm{p}$.

4. MARTY, C. - Usinages par procédés non conventionnels. Paris, Masson Editeurs, 1971, 336 p.

5. SME - Thermal machining processes. Michigan, Society of Manufacturing Engineers, 1979. 252 p.

6. SME - Tool and manufacturing engineers handbook. Michigan, 1975, Mo Graw-Mill. Paginação irregular. 
ACABAMENTO (finishing)

Regime utilizado em UEE que confere à peça uma rugosidade supexflcial inferior ou igual a $1,6 \mathrm{~mm}$ (VDI 24)。

ACABAMENTO SUPERETCTAI, (surface finish)

Medida da rugosidade superficlal de um componen-te apös um tratanento final, referida ao perfil da superficie.

ACURACIDADE DO PROCESSO (process accuracy)

Medida estatística do grau com que ur fenômeno observado en un processo difexe da especificaço exigida.

AGUA DESIONJZADA (desionized water)

Agua tratada para um estado näo condutor, pelo processo de desiont\%ação.

AJUSTE DE PLUXO (centerflow adjustment)

Adequação da pressão e vazão do fluido de trabatho, feita por melo de uma välvula manual.

SNODO (anode)

Elemento coletor de elétrons. A um elétrodo com zona de polaridade positiva. 
ARCO - V. ARCO ELESRICO

ARCO ELETRICO

Fluxo contínuo de corrente ejétrica entre dois e lëtrodos. Na ocorrêncìa de um arco em um processo de UEE, haverä desgaste no elëtrodo e erosão irregular na peça.

CABEÇOTE (ram)

Membro mövel de u'a mäquina de EE, no qual. se alojam o elëtrodo e o fixador do elëtrodo. o seu movimento pode ser servo-comandado por um motor eletrico, um regulador eletrohidräulico ou um sistema de controle adaptativo.

CAMADA RESSOI,IDIFICADA (resolidified layer)

Camada de material fundido e ressolidificado, de positada na superfície da peça usinada.

CARBONIZAÇÃO (carbonization)

Conversão em carbono ou em fuligem de uma substância carbônica.

CATODO (cathode)

Elemento emissor de elétrons.

CENTELHA (spark)

Descarga elëtrica de curta duração, devido à rutura subita e espontânea do ar ou de algum outxo material diejétrico que separa dois terminais. E acompanhada de uma emissão momentânea de luz.

CICLO DE SERVIÇO (duty cycle)

E uma sequência completa do fenômeno de descarga, que engloba os tempos de ionização, do "gap", descarga propriamente dita, expulsão das partícu 
las erodidas da zona de usinagem e desionização do dielëtri.co.

CTRCUTTO DE CARGA (charge circuit)

Circuito armazenador da energia de descarga. Pode ser do tipo de relaxação, val.vulado, transistorizado ou integrados digitais.

CIRCUTTO DE DESCARGA (discharge circuit)

Circuito que libera a energía armazenada pelo cir cuito de carga. E caracterizado pelos elétrodos, sua impedância e capacitânctia do "gap".

CIRCUITO GAGO (sttuter circuit)

E um tipo de circuito que interrompe a corrente de saida quando ocorre un curto-circuito no "gap" e, em seguida, gera pequenos pulsos de corrente para "verificar" se o curto-circuito cessou.

COLOIDE ( COLloid)

sistema no qual una fase é composta de partículas sólicias com dimensões entre $10^{-3}$ a 1 urn, e que está disperso em uma fase diferente.

COMPENSAÇÃO DO PESO DO ELETTRODO (eletrode wej.ght compersation)

Regulagem no paràmetro de ganho do sistema de controle do movimento do cabeçote de u'a máçuina de eletroerosäo, para assegurar a sua estabilida de durante o processo, devido às diferentes dimensöes dos elétrodos. 


\begin{abstract}
CONTAIINAÇÃO DO FLULDO DIELETRTCO (dielectric Fluid contamination)

processo de introdução no dielétrico de quaisquer partículas sölidas, oriundas da poluição am biental, da eletroerosão etc., e particulás 11 quidas provenientes da umidade do ar,substâncias decorrentes da decomposição do dielétrico etc.
\end{abstract}

CRATERA (crater)

Pequena cavidade deixada em uma superficie de uma pega eletroerodjda por uma descarga.

"CRESCIMENTO" DO ELETRODO (electrode "growth")

EFeito de eletrodeposição que ocorre sob certas condições de eletroerosão, fazendo com que o material da peça se deposite no elëtrodo, aumentan do as suas dimensões sem controle.

CUR'IO--CIRCUTTO (short-cixcuit)

Contato fisico entre os elétrodos, de efeitos da nosos à usinagem ejetroerosiva.

DESBASTE (rough cut)

Regime utilizado em UEE, que confere à peça una rugosidade superficial igual ou maior que 5,0 $\mathrm{mm}$ (VDI 34).

DESCARGA ELETRICA (electric discharge)

passagem de eletricidade por um dielétrico,em ge ral acompanhada de uma centelha ou arco.

DESCARGA ANORMAL (anomalous discharge)

Descarga com baixas caracteristicas eletroerosi vas que ocorre antes de concluída a formação dos "streamers"; a energia dessa descarga é absorvida quase totalmente pelo fluido de serviço. 
DESGASTE DO ELETRODO (electrode vear)

Quantidade de matertal removido do elétrodo-ferramenta.

DESGASTE VOLUMETRTCO (volumetric wear)

Desgaste total do elëtrodo, expresso em unidades de volume.

DESTONIZACGAOO DO FJUTDO (Eluid deionization)

Retorno ao estado dielétrico de um fluido ioniza do, apös terem sido removidas todas as fontes de Ionização, envolvendo difusão de íons às paredes do reservatörio e a recombinação de volume de ions positivos e negativos.

DIELETRICO (dielectxic)

Um material ejétrico isolante, ou un material no qual se pode manter um campo elétrico com un mínimo de perdas de energia.

ELETRODO (electrode) OU ELETRODO-WERRAMENTA (tool-e lectrode) E a ferramenta eletroerosiva. Ela deve ser feita de um material bom condutor de eletricidade. Sua geometxia é comumente una imagem negativa da for ma desejada na peça acabada, com as suas dimensões ajustadas para levar em conta o sobrecorte para o regime utilizado.

ELITRODO ESCALONADO (stepped electrode)

E um elétrodo que possui un estägio com dimensöes reduzidas para desbaste e un ou mais estägios de acabamento, com dimensöes progressivamen te malores para a usinagem de furos passantes. 
ELETRODO MOLTIPIO (split electrode)

São dois ou mais elëtrodos em u'a mäquina, isola dos entre si. Cabos separados, ligados a cada elëtrodo, säo provenientes de canaís de saïda do gerador e simultaneamente são feitas descargas de cada elemento pela sua jigação com o canal correspondente.

EROSÃO (erosion)

Em UEE, é a remoção de metal dos elêtrodos.

ESTABILIDADE DE USINAGEM (machining stability)

Estado de desenvolvimento da usinagem. Diz-se que a estabilidade de usinagem é boa se a progressão da usinagem ë regular e isenta de curtos-circuitos e de descargas anormais.

FERRAMENTA (t:OO1)

Ver elétrodo.

FLUTDO DIELETRTCO (dielectric fluid)

Em un processo de UEE, é, ern geral, un hidrocarboneto de baixa viscosidade (querosene) ou ägua desionizada, onde se encontram inersos os eletro. dos. O fluido dielétrico de serviço preenche o "gap" entre o elétrodo e a peça, agindo como iso lante elëtxico atë que seja atingido um valor es pecífico de tensão no "gap". Quando tal ocorre, ele se ioniza, tomando-se um condutor elétrico, permitindo um fluxo de corrente pelo caminho ionizado, até a peça. Ele serve também para refrige rar a zona de trabalho e para expulsar as particulas geradas pela erosäo da zona de trabalho. 
FREQUENCIA DE DESCARGAS (discharge frequency)

Nümero de descargas por segundo, na zona elétrodo-peça.

FURO DE LAVAGEM (Flushing hole)

Furo executado na peça ou no elétrodo, que serve para introduzix o dielëtrico no "gap", para fins de lavagem.

"GAP" (gap)

Distância entre o elëtrodo e a peça, durante a $\underline{u}$ sinagem.

GERADOR (power supply)

Dispositivo de um sisterna de vEs que fornece a nergía que produz a descarga elétrica entre o elétrodo e a peça.

GERADOR DUAL (dual power supply)

Geradores duplos, alojados em um sö gabinete, que podem operar com duas mäquinas de UEE, simultaneamente.

"HUN'ING" (hunting)

Movimento altexnado do cabeçote de $u$ 'a mäquina de eletroerosão, durante o coxte. Ele pode ocoxrer devido às condições inadequadas de lavagem do "gap", sensibilidade extremamente elevada do servo-sistena, deposiçäo de resíduos carbônicos no fundo de una cavidade eletroerosiva etc.

INSTABILIDADE DA USINAGEM (machining instability)

Estado que altera o desenvolvimento normal e pre ferido da usinagem. pode ser caracterizado por curtos-circuitos e/ou descargas anormais. 
IN'IENSIDADE DE DESCARGA (discharge strenght)

Quantidade de energia da descarga.

LAVAGEM (flushing) (flow)

Processo de passagem do dielétrico pelo "gap", para remover as partículas produzidas pela UEE.

JAVAGEM CENTRAL (centex flow flushing)

Método de fazer jorrar dielétrico por um furo central feito no elétrodo.

LAVAGEM INVERTIDA (reverse flow flushing)

Sistema de lavarjem por injeção pelo copo metäli.o de la vagem sob a peça usinada.

LAVAGEM I,ATERAI، (latera]. Flow flushing)

o mesmo que lavagem superficial.

LAVAGEM POR EXSUDAÇÃO (swarf flow flushing)

Sistema de lavagem que consiste em injetar o die létrico sob pressão no intexion de um elëtrodo feito de material poroso. o fluido dielëtrico am travessa os poros e executa a lavagem com efici.ência.

LAVAGEM POR INJEÇÃO (injection flushing)

Mêtodo de lavagem que utiliza a circulação força da de dielétrico sob pressão, pelo "gap".

LAVAGEM POR ASPIRAÇĂO OU SUCÇÃO (vacuum flushing)

Mëtodo de lavagem que utiliza uma pressão vacuométrica de suç̧ão para aspirar o dielëtrico contaminado do "gap", para um copo metálico posto sob a peça usinada e, daí, paxa o tanque de serviço. 
LAVAGEM PULSANTE (pulsed flushing)

Método de lavagem que sincroniza a injeção do fluido dielétrico com o levantamento periódico do cabeçote, assegurando uma eficiente limpeza na zona de usinagem.

IAAVAGEM SUPERFICTAL (surface flushing)

Mëtodo que utiliza bicos ou manguejras para dire cionar jatos de dielétrico na ärea de corte, pam ra afastar os residuos. Em geral é utilizado com o sistema de levantamento periódico do cabeçote.

LIMTTADOR DE CURSO (limit switch)

If um dispositivo, regulável atravës de um micrômetro, que serve para monitorar a profundidade de usinagem em um ponto pré-determinado, atingin do o qual o cabeçote è cesenergizado automaticamente.

MESA DF COORDENADAS (coordinates table)

Mesa de u'a mäquina-ferramenta que é utilizada para o posicionamento preciso das peças com refe rência à ferramenta e à zona de usinagem, definindo a localização geomëtxica da peça em um sis tema de coordenadas cartesianas.

MOTOR DE PASSO (stepping motor)

Un motor que gira em movimentos angulares essencialmente uniformes e curtos, ao contrário de gi xar continuadamente. Os passos angulares são obtidos eletromagneticamente.

NOCLEO (core)

Haste que permanece apös uma usinagem com um elé trodo que possui um furo de lavagem. Também conhecida como alma, espiga etc. 
PEÇA (vorkpiece)

Em usinagem de materiais, diz-se que $\vec{e}$. o material que sofre o processo, até a sua obtenção fi nal.

PLASMA (plasma)

Gäs fortemente ionizado que contém nümeros iguais de ions e elëtrons em densidade suficiente tal que o comprimento de blindagem de Debye é muito menor do que as dimensões do volume do gäs.

POLUIÇÃO DO LIQQUDO DIELETRICO (dielectric polluition)

ver contaminação do djelétrico.

PONTO DE FULGOR (Elash point)

Temperatura na qual os vapores de urn líquido vo-Játi.1. em mistura com ax, entram em j.gnição es-. pontâneamente. E um fator decisivo na escolha do dielétrico para a UEE.

PRESST̃O DE RECALQUE DO DTELETRTCO (supply dielectric

pressure)

Pressão manometrica do fluido dielétrico bombeado do tanque de dielëtxico para o reservatöxio de serviço.

PRE-USINAGEM (pre-machining)

Usinogem prévia da pega, para reduzj.r o volume de material a sex removido, por meio de processos convencionais de usinagern.

PUISADOR (pulsator) (woodpeckex device)

Uma unidade acessónia de u'a mäquina UEE para fá zer o elétrodo se restriar periodicamente, em um certo intervalo de tempo e ajudar na lavagem de 
uma cavidade profunda e/ou cega. Ele faz o elëtrodo movex-se como um pistão em uma câmara.

PULso (pulse)

Descarga de uma quantidade de energia elétrica, com voltagem e amperagem pxé-estabelecidas, e agindo em un intervalo de tempo, tambëm pré-estabelecido.

Ra ( Ra)

Desvio médio aritmético. Média dos valores absolutos das ordenadas de perfil efetivo em relação à linha mëdia en um comprimento de amostragem.

RELAÇÃO DE DESGASTE (wear ratio)

Percentagem em volume do elêtrodo gasto, compara do com o volume retixado do material da peça, de vido à UEE.

RESERVATORIO DE SERVIÇO (djelectric tank)

Recipiente superposto à mesa de coordenadas que encorra o fluido dieletrico de lavagem, onde os ejêtrodos permanecem inexsos durante a usinagem.

RIGIDEZ DTELETRICA (dielectric strength)

Em UEE, ë o potoncial necessärio para quebrarlio nizar) o "gap" imerso en fluido, comumente expresso em quilovolts por metro.

RUGOSIDADE SUPERFICIAL (surface roughness)

Soma das diferenças geomëtricas provenientes de desvios de forma da ferramenta, do processo de formação do cavaco ou partícula e da modificação estrutural. por ação química, resultantes de ações inerentes ao processo de usinagem. 
SEMI-ACABAMENTO (senifinishing)

Regime utilizado em UEE, que confere à peça uma rugosidade superficial iqual. ou maior que $1,6 \mu \mathrm{m}$ (VDT 24).

SERVO-AVANÇO DO ELETRODO (electrode sexvo feeding system) Dispositivo que aciona e controla o movimento do cabeçote de u'a mäquina de eletroerosão.

SOBRECORTE (overcut)

Una cavidade eletroerodida ê sempre maior do que o elétrodo utj.jizado para usinä-la. A di ferença entre a dimensão do elëtrodo e da cavidade usina da é denominada sobrecorte. O sobrecorte diametral, ou total, é duas vezes o valor do sobrecor te lateral.

SOBREMETAL PARA ACABAMENTO (a.llowance machining)

Diferença entre a dimensão do elétrodo de acabamento e a dirnensão correspondente da cavidade ou orifício já usinado por meio do ejëtrodo de des-baste ou semi-acabamento.

SUPRESSOR DE ARCO (arc suppressor)

Circuito no gerador de u'a inäquina de eletroerosão que reduz a possibilidade de abertura de arco.

TANQUE DO DTELETRTCO (dielectric tank)

Recipiente responsāvel pela decantaçăo, refrigeração, armazenamento e suprimento do fluido dielétrico ao reservatório de serviço. 
TEMPO ATIVO (on time)

Tempo de duração de uma centelha eletroerosiva.

TEMPORIZADOR DO PUISO (pulse timer)

Disposjtivo utilizado para ajustar, a duração dos tempos ativo e passivo da centelha. Nas mäquinas modexnas, os tempos ativo e passivo podem ser ajustados individualmente.

TEMPO DE DESIONTZAÇÃO (deionization time)

Tempo necessárío para que o Elutdo de serviço re cupere as suas propriedades dielétricas.

TEMPO DE TONTZAÇÃO (ionization time)

Intervalo de tempo en que una a.d.p. $\vec{e}$ aplicada ao "gap", antes que ocorra a descarga.

TEMPO DR RESPOSlA DO SERVO (servo response time)

Tempo transcorrido entre a excitação e a resposta a nível de regine, para um sistema de servo- comando.

TEMPO PASSTVO (Off time)

Intervalo de tempo entre dois pulsos, determinado pelo multivibrador, tambëm denominado tempo de pausa ou tempo aberto.

TENSÃO NO "GAP" (gap voltage)

Ver tensäo em vazio no "gap" e tensão de servi.ço no "gap".

TENSÃO EM VAZTO NO "GAP" (open circui.t voltage) D.d.p. no "gap", antes que ocorra a centelha. 
TENSÄO DE SERVIÇO NO "GAP" (closed circuit voltage)

D.d.p. no "gap" durante a descarga.

US INAGEM SEM DESGASTE (no wear machining)

Modo de operação no processo UeE, onde o desgasm te do elêtrcdo é insignificante, devido à inversão de polaridade do circuito e manutenção da frequência de descargas em uma faixa ótima, de acor do com cada combinação de matexiais dos elëtrom doss.

VEJOCIDADE DE REMOÇÃO DE MATERTAL (naterial removal rate)

Volume de material. removido da peça em um intervalo de tempo. E comunente expresso em milimetros cübicos por minuto.

VELOCIDADE DE AVANÇO DO CABEÇOTE (feeding ram ratio)

velocidade do movimento relativo entre ferramenta e peça, na direçäo principal de corte.

ZONA AFETADA PELO CAJOR (heat affected zone)

Camada superficial na qual o processo eletroerosivo altera a estrutura do material usinado e as suas propriedades mecânicas devido aos efejtos térmicos dá descarga. 
DIMENS IONAMENTO DE ELERRODOS-FERRAMENTAS E ESTIMATTVA DO TEMPO DE USTNAGEM POR ELETROEROSÃO

A minimizaçäo do tempo total de fabricação de um produto ë uma necessidade que se torna mais acentuada a ca da dia. Tempo de fabricação, afinal de contas, associa-se diretamente ao custo do produto.

Há outra exigência em paralelo que tambëm preocu pa sobremaneira a engenharia de fabricação: a qualidade da superfície usinada. A melhoria dessa qualidade acarreta a majoração do tempo de fabricação.

Portanto, existem condições de contorno para o problema, teoricamente bem definj.das; na prática, inúmeros fatores interagem no delineamento de tais contornos, sejam de natureza tëcnicca, econômica, polittico-sociall.

$\mathrm{Na}$ usinagem por eletroerosão, o problema se agra va pelas reconhecidamente baixas velocidades de remoçäo de material, quando comparadas àquelas dos processos convencionais de usinagem. Ut.j.jizando-se a velocidade mäxima de remoção de matejial en UEE, a qualidade da superficie usinada ë a pior possível, o desgaste do elétrodo-ferramenta é crítico, a conicidade é elevada, a imprecisão do proces-so aumenta etc.

As melhores qualidade superficial e precisão dimensional da peça usinada são obtidas mediante baixos níveis de energia de descarga e altas frequencias de descargas, o que confere ao processo velocidades de remoção de material reduzidíssimas.

E conveniente, portanto, utilizar majs de um regime de usinagem na fabxicação de uma peça por eletroerosão. Como, na maioria dos casos, cada regime está associa- 
do a um elëtrodo-ferramenta e, äs vezes, a um dispositivo especial de fixação desse elétrodo, os custos adicionais decorrentes de ferramentas e dispositivos complementares ë um fator linitante do nümero de regimes a serem usados.

Em geral, recomenda-se pelos menos dojs regimes, sendo um de desbaste e outro de acabamento; sempre que pos sível, a peça a sex eletroerodida é prë-usinada por algum processo tradicional de usinagem.

O fluxograma apresentado na Figura 78 sintetiza - procedinento mais adequado à deterninação dos parâmetros tecnolögicos do processo eletroerosivo que possibilitem a obtenção de uma peça eletroerodida e que atende às especiFicações de projeto relativas ao acabamento superficial e à acuracidade dimenstomal.

Uma vez deteminado o material da peça, seleciona-se o material que comporá o elétrodo-ferramenta para o regime a ser executado com base nos parâmetros tecnológicos e custo de fabricação desse elétrodo. A sesuir, calcula-se a ârea da seção transvexsal do elétrodo-ferramenta; se a sua supexfície frontal não for plana, ou estiver inclinada em relação ao plano da mesa de serviço, a ärea frontal desse elétrodo-ferramenta passa a sex o parâmetro de interesse.

A curva da Figura 49 associa a velocidade de remoção de material à ärea frontal ötima do elëtrodo-ferramenta. A utilização dessa curva proporciona as molhores condições de usinabillidade com o mínimo dispêndio de energia e desgaste do eletrodo-ferramenta, adequando com maior propriedade o processo eletroerosivo à apljcação particular. Näo convém, portanto, distanciax-se muito do valor in dicado para a VRM.

Conhecido o valor indicado para a velocidade de remoção de material, selecionarn-se o regine de usinagem e as condiçöes de lavagen propícias à aplicação. Nesse ponto, é imperiosa uma anajise comparativa de custos entre os 
diversos processos que possibilitem a fabricação da peça requexida, cono aquela apresentada na segäo 4.4 .

$A$ determinação do sobxecorte, conicidade e rela'̧ão de desgaste para o regime de usinagem e condiçóes de lavagem escolhidas é feita através de consulta às curvas e tabolas respectivas, como aquelas mostradas nas jijguras 56 a 75 e na Tabela 6.4, que são una função do tipo de gerador elétrico e dos matexiajs utjilizados como elétrodos.

Nesse ponto, deparamse com um outro problema de natureza tëcnico-econômica : trata-se de verificar a neces sidade da programação de um ou majs regimes de usinagen, que proporcionem un tempo de fabricação relativamente curto e una qualidade supecflcial enquadrada nos padrões re-queridos pelo projeto.

Como regra geral, deve-se utilizar dois regimes de usinagem quando se desejar um produto com uma rugosidade superficial Ra $=2,20 \mathrm{\mu m}$, ou três regimes de usinagem, quando o projeto requerer uma rugosidade superficial Ra $\leqslant 1,26 \mu \mathrm{m}$ e a ärea frontal do eletrodo for superior a 200 inn $^{2}$.

Uma vez de finido o nümero de passes ou regines de usinagem, é necessärio confrontar os custos relativos à compra ou fabricação dos elétrodos e/ou porta elëtrodos com plementares com a economia resultante da reduçäo do tempo total de usinagem devido à programação de um ou nais regimes intermediärios.

No dimensionamento dos elëtrodos de desbaste e semi-acabanento, deve-se levar em conta os desvios de forma e posiçäo introduzidos com a troca dos porta-elétxodos e dos elëtrodos, alóm dos desvios relativos à própria máquina eletroerosiva.

O procedimento adequado a ser seguido é simples:

a) Com a área frontal do ejëtrodo calculada, consultar, na. pigura 49, o valor mais adequado para a VRM; 


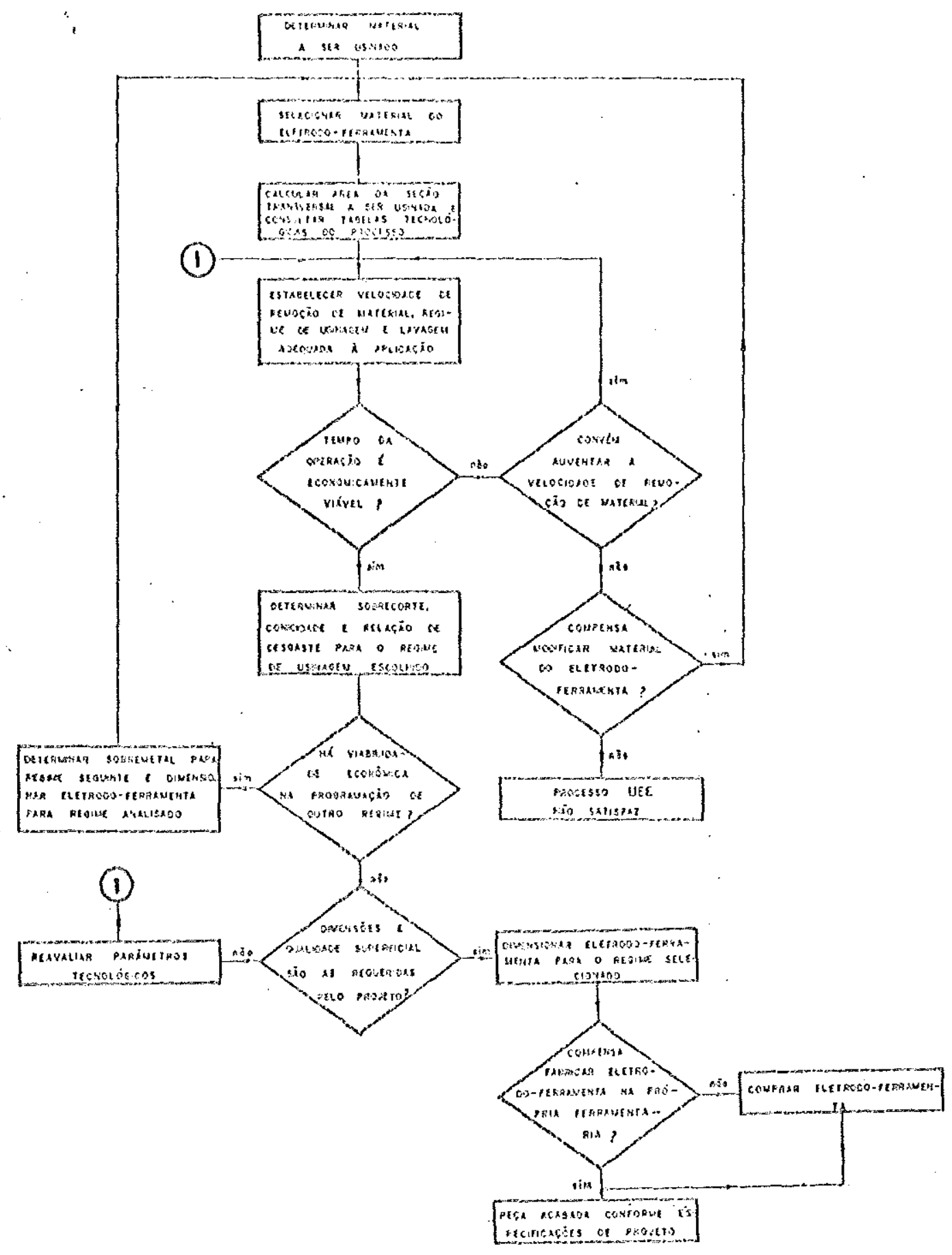

Fig. 78 - Procedimento mais adequado à seleção das condições de usi nagem e dimensionamento dos elétrodos em UEE 
b) Determinada a VRM, selectonax as condições de usinagem propicias à aplicação (tensão, amperagem, tipo e condi-Ções de lavagem etc.), através de consulta às Figuras 56 a 75 , dali retirando os valores de $\mathrm{RD}$, Ra e ${ }^{\mathrm{L}} \mathrm{I} i$

c) Cada dimensäo do elêtrodo de desbaste deve seri iqual. à dimensão correspondente, na peça, do regime seguj.nte, me nos $1,5 S_{L}$; cada dimensão do elëtrodo de acabamento deve ser igual à dimensão final correspondente, na peça, menos o sobrecorte lateral de acabamento, para os ajustes selecionados;

d) A consulta à Tabela 6.3 fornece o valor da conicidade da peça usinada. Determinada essa grandeza e a profundi. dade da cavidade a ser usinada, calcular o volume usina do e, dividindowo pela VRM, obter o tempo de usinagern a travës desse regine; se a lavagen escolhida for pulsante com elevaçäo pexiödica do elëtrodo-ferramenta, adicionar o tempo total gasto para oxecutar a lavagem ao tempo de usinagem;

e) Com a conicidade, $\mathrm{RD}$ e a profundidade da peça a ser usi nada, verificar o comprimento minimo do olétrodo-ferramenta para cada regine analisado e prognosticar a tolerância final da peça a ser usinada.

Dimensionados os elétrodos e selecionados os ajustes a serem efetuados, depara-se com uma ultima decisão: para a geometria da cavidade a ser usinada, ë mais con veniente comprar ou fabricar os elëtrodos-ferramentas? Tra ta-se de uma decisäo muito particular, que depende da apli caçăo, das possibilidades e custos da ferramentaria a que estä associada a mäquina-ferramenta eletroerosiva e da poIftica adotada pela empresa, nesse tocante. 